CÁTIA ALEXANDRA LEÇA GRAÇA

DEGRADATION OF PERSISTENT PESTICIDES VIA ADVANCED OXIDATION AND REDUCTIVE PROCESSES 
Este exemplar foi revisado e corrigido em relação à versão original, sob responsabilidade única do autor e com a anuência de seu orientador.

São Paulo, de de

Assinatura do autor:

Assinatura do orientador:

Catalogação-na-publicação

\section{Graça, Cátia}

DEGRADATION OF PERSISTENT PESTICIDES VIA ADVANCED

OXIDATION AND REDUCTIVE PROCESSES / C. Graça -- versão corr. -São Paulo, 2017.

$187 \mathrm{p}$.

Tese (Doutorado) - Escola Politécnica da Universidade de São Paulo. Departamento de Engenharia Química.

1.Pesticidas persistentes 2.Processos oxidativos avançados 3.Metais de valência zero I.Universidade de São Paulo. Escola Politécnica.

Departamento de Engenharia Química II.t. 
CÁTIA ALEXANDRA LEÇA GRAÇA

DEGRADATION OF PERSISTENT PESTICIDES VIA ADVANCED OXIDATION AND REDUCTIVE PROCESSES

Tese apresentada à Escola Politécnica da Universidade de São Paulo para obtenção do título de Doutor em Ciências 

CÁTIA ALEXANDRA LEÇA GRAÇA

DEGRADATION OF PERSISTENT PESTICIDES VIA ADVANCED OXIDATION AND REDUCTIVE PROCESSES

Tese apresentada à Escola Politécnica da Universidade de São Paulo para obtenção do título de Doutor em Ciências

Área de Concentração:

Engenharia Química

Orientador: Prof. Dr. Antonio Carlos Silva Costa Teixeira

Co-orientador: $\mathrm{Dr}^{\mathrm{a}}$. Adriana Correia de Velosa 

"Para ser grande, sê inteiro: nada

Teu exagera ou exclui.

Sê todo em cada coisa. Põe quanto és

No mínimo que fazes.

Assim em cada lago a lua toda

Brilha, porque alta vive."

Ricardo Reis

(Heterónimo de Fernando Pessoa) 


\section{AGRADECIMENTOS}

Uma tese é pouco para agradecer a todos os que me ajudaram neste caminho. Em primeiro lugar agradeço aos meus Pais que, mesmo sofrendo com a minha partida, nunca deixaram de me incentivar a seguir os meus sonhos, mesmo sendo a $8000 \mathrm{~km}$ de casa e "por mares nunca d'antes navegados". Sem o vosso apoio incondicional não existiria esta tese, esta aventura, ou até mesmo nada do que conquistei até hoje. A vocês devo tudo.

Ao Prof. Dr. Antonio Carlos Teixeira, pela oportunidade, orientação e compreensão ao longo dos últimos três anos.

À Dr. a Adriana Correia de Velosa por todos os ensinamentos, incentivos e "puxões de orelha”, os quais me ajudaram a crescer na ciência e a olhá-la de um novo prisma.

Ao Ricardo, por todo o amor, paciência (muita!) e companheirismo ao longo desta aventura, que sem os quais tudo teria sido mais difícil.

Aos meus amigos e familiares de Portugal, que apesar da distância, sempre se fizeram sentir perto.

À família portuguesa que encontrei no Brasil, por terem ajudado a levar tudo de forma mais leve e a sentir menos saudades de casa.

Aos meus colegas de laboratório, especialmente Marcela Prado Silva, Arlen Costa, Danielle Matsumoto, Ana Paula, Christiane Fonseca, Flaviane Santos, Leandro Goulart, Paty Metolina, Bruno Ramos e Leonardo Diniz, pelo apoio durante a execução do trabalho e pelos momentos de descontração nas horas de maior pressão.

Aos alunos de graduação Lucas Fujita e Flávio Chiquetto, pela ajuda na execução das experiências, sem a qual não teria conseguido dar conta de concluir todos os trabalhos em tempo recorde.

Às colaborações que tanto incrementaram este trabalho, nomeadamente ao grupo LAREX, em especial à Ana Carolina, por toda a ajuda nas mais variadas técnicas analíticas e ao grupo Dempster, nomeadamente Dr. ${ }^{a}$ Lidiane de Andrade, Dr. ${ }^{\text {a }}$ Anita Mendes e Meriellen Dias, por toda a ajuda na reta final e por "adoçarem" tantas vezes os cafés da tarde. 


\section{RESUMO}

Na presente Tese de Doutorado foram abordados tanto processos oxidativos avançados (POA), como processos redutivos por metais de valência zero, na degradação de dois pesticidas considerados persistentes no meio ambiente: amicarbazona (AMZ) e clorpirifós (CP). No capítulo I são apresentados os estudos realizados com diversos POA, mediados por radicais sulfato $\left(\mathrm{SO}_{4}{ }^{-}\right)$e hidroxila $\left({ }^{\circ} \mathrm{OH}\right)$, aplicados da $\mathrm{AMZ}$. Num primeiro estudo foi explorada a ativação do oxidante persulfato (PS), de diferentes formas, tais como radiação UVA, $\mathrm{H}_{2} \mathrm{O}_{2}$ e $\mathrm{Fe}(\mathrm{II})$, assim como a combinação de radiação UVA com $\mathrm{Fe}(\mathrm{II})$, $\mathrm{Fe}(\mathrm{III})$ e complexos de $\mathrm{Fe}(\mathrm{III})$. Aqui também foram investigados os efeitos de diversas variáveis reacionais, tais como $\mathrm{pH}$, concentração inicial de reagentes e de pesticida, adição de um segundo oxidante $\left(\mathrm{H}_{2} \mathrm{O}_{2}\right)$ e adição de diferentes espécies de ferro. Os testes realizados, para efeito de controle, referentes à irradiação das espécies de $\mathrm{Fe}(\mathrm{III})$ na ausência de PS, despertaram o interesse para um estudo mais aprofundado sobre o efeito da fotólise destas espécies na degradação da AMZ, surgindo assim o segundo trabalho. Neste utilizou-se um projeto experimental de Doehlert, para avaliar o efeito de duas variáveis em simultâneo quanto à degradação da AMZ: pH e proporção Fe(III): ligante, sendo o ligante um dos seguintes carboxilatos: oxalato, citrato ou tartarato. Um modelo de superfície de resposta, que correlaciona a taxa de degradação observada $\left(k_{\mathrm{obs}}\right)$ em função do $\mathrm{pH}$ e proporção $\mathrm{Fe}(\mathrm{III})$ :ligante foi obtido para cada um dos complexos de $\mathrm{Fe}(\mathrm{III})$ estudados. Os processos explorados, tanto no primeiro como no segundo estudo, se mostraram eficazes na remoção da AMZ, porém nada se sabe acerca da remoção da toxicidade. Para tal, foi desenvolvido um terceiro estudo dedicado à avaliação da toxicidade da solução de AMZ, antes e após a aplicação de cada um dos processos

anteriormente abordados, contra cinco micro-organismos: Vibrio fischeri (toxicidade aguda); Tetrahymena thermophila, Chlorella vulgaris (toxicidade crônica); Escherichia coli e Bacilus subtilis (atividade antimicrobiana). O último estudo abordado no capitulo I é referente à aplicação de metais de valência zero também nos POA, correlacionado assim o capítulo I e o capítulo II. Como tal, foi feito um estudo de ativação de PS por meio de ferro de valência zero $\left(\mathrm{Fe}^{0}\right)$, em que se investigou a influência de diversas variáveis por forma a inferir sobre a aplicabilidade prática deste processo. Pesticidas organoclorados apresentam maior resistência à degradação por processos oxidativos do que redutivos, sendo preferível o último na degradação desta importante classe de contaminantes. Como tal, o capítulo II se refere à degradação redutiva, por meio de 
diferentes metais de valência zero e partículas bimetálicas, do pesticida organoclorado CP. Além do amplamente explorado $\mathrm{Fe}^{0}$, outros metais podem ser aplicados neste processo, pelo que, neste estudo, explorou-se a potencialidade de $\mathrm{Zn}^{0}$ e $\mathrm{Cu}^{0}$ comparativamente ao primeiro. Ainda neste estudo foram investigadas duas formas de aumentar a reatividade dos metais: i) no caso do $\mathrm{Fe}^{0}$ e $\mathrm{Zn}^{0}$, revestindo com um metal mais nobre $(\mathrm{Cu})$, por forma a observar o efeito catalisador do último no sistema bimetálico; ii) realizando um pré-tratamento à superfície dos metais .

Palavras-chave: Pesticidas persistentes; Amicarbazona; Processos Oxidativos Avançados (POA); Persulfato; radiação UVA; Clorpirifós; Metais de valência zero 


\begin{abstract}
In this Thesis either advanced oxidation or reductive processes are investigated for the degradation of two pesticides considered persistent in the environment: amicarbazone (AMZ) and chlorpyrifos (CP). In chapter I, different advanced oxidation processes (AOPs) driven by sulfate $\left(\mathrm{SO}_{4}{ }^{\circ}\right)$ and hydroxyl radicals $\left({ }^{\circ} \mathrm{OH}\right)$ were applied to the degradation of AMZ. In the first study, several persulfate (PS) activated reactions were explored for AMZ degradation, namely activation with UVA radiation, $\mathrm{Fe}(\mathrm{II})$ and $\mathrm{H}_{2} \mathrm{O}_{2}$, as well as the combination of UVA radiation with $\mathrm{Fe}(\mathrm{II}), \mathrm{Fe}(\mathrm{III})$ and $\mathrm{Fe}(\mathrm{III})$-complexes. Here, the influence of different reaction variables, such as solution $\mathrm{pH}$, reactants and pesticide initial concentrations, addition of a second oxidant $\left(\mathrm{H}_{2} \mathrm{O}_{2}\right)$ and the addition of different iron catalysts were also investigated. Control experiments regarding the photolysis of iron species in the absence of PS captured our interest and, with the aim of exploring more deeply this process on AMZ degradation, a second investigation was carried out. In this second study, a Doehlert experimental design was applied to investigate the simultaneous effects of two variables on $\mathrm{AMZ}$ degradation: $\mathrm{pH}$ and $\mathrm{Fe}(\mathrm{III})$ :carboxylate ratio, where the carboxylate could be oxalate, citrate or tartrate. A response surface model for the observed degradation rate $\left(k_{\mathrm{obs}}\right)$ as a function of $\mathrm{pH}$ and $\mathrm{Fe}(\mathrm{III})$ :carboxylate ratio was obtained. The processes explored in both aforementioned studies revealed to be effective for AMZ removal, although nothing is known yet about their effectiveness regarding toxicity removal. Given that, a third study was carried out, where the toxicity of $A M Z$ solutions, before and after submission to the processes studied was evaluated towards five microorganisms: Vibrio fischeri (acute toxicity), Tetrahymena thermophile, Chlorella vulgaris (chronic toxicity), Escherichia coli and Bacilus subtilis (antimicrobial activity). The last investigation detailed in chapter I is related with the application of zero-valent-metals on PS activation, which is a subject that links this chapter with the following one. For that, zero-valent-iron (ZVI) was investigated as a PS activator and the influence of variables that help to assess the environmental applicability of this process. In general, organochlorine pesticides reveal a higher resistance to oxidation than reduction, the latter process preferred when the aim is to degrade that important class of contaminants. Therefore, in chapter II the reductive degradation of CP by means of zero-valent-metals and bimetallic particles was investigated. ZVI has been extensively applied for that purpose. However, besides iron, other zero-valent metals can be potential reactive materials for reductive degradation and hence, in this study, the
\end{abstract}


effectiveness of $\mathrm{Zn}^{0}$ and $\mathrm{Cu}^{0}$ was also explored in comparison to that widely reported for ZVI. Furthermore, two different ways of enhancing metals reactivity were here explored: i) by coating $\mathrm{ZVI}$ or $\mathrm{Zn}^{0}$ with a more noble metal $(\mathrm{Cu})$, in order to analyze the copper catalytic effect on the bimetallic system; ii) by different surface pretreatments.

Keywords: Persistent pesticides; Amicarbazone; Advanced Oxidation Processes (AOPs); Persulfate; UVA radiation; Chlorpyrifos; Zero-valent metals 


\section{LIST OF FIGURES}

Figure 1. Pesticides sales in Brazil by type of pesticide............................04

Figure 2. Structural chemical formula of amicarbazone..............................06

Figure 3. Chemical structure of chlorpyrifos.................................. 07

Figure 4. Structural chemical formula of persulfate............................... 15

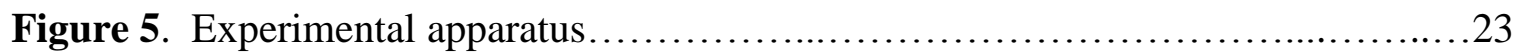

Figure 6. (A) Effect of PS on measured $k_{\mathrm{obs}}$; (B) Effect of AMZ initial concentrations on the initial AMZ degradation rate, $r_{0}$. Conditions: (A) $[\mathrm{AMZ}]_{0}=41.4 \mu \mathrm{mol} \mathrm{L} \mathrm{L}^{-1}, 0<[\mathrm{PS}]_{0}<5$ mmol L ${ }^{-1}$; (B) $[\mathrm{PS}]_{0}=5 \mathrm{mmol} \mathrm{L}^{-1}, 41.4<[\mathrm{AMZ}]_{0}<207.2 \mu \mathrm{mol} \mathrm{L}{ }^{-1}$. Error bars are not included since they are smaller than the symbols... .25

Figure 7. Effect of $\mathrm{Fe}(\mathrm{II})$ addition on $\mathrm{AMZ}$ degradation driven by PS/UVA at free $\mathrm{pH}$.

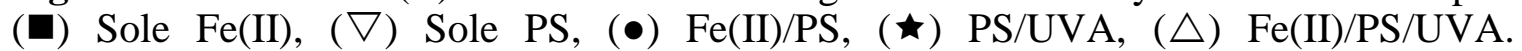
Experimental conditions: $[\mathrm{AMZ}]_{0}=(41.4 \pm 8) \mu \mathrm{mol} \mathrm{L}{ }^{-1},[\mathrm{Fe}(\mathrm{II})]_{0}=0.134 \mathrm{mmol} \mathrm{L}{ }^{-1},[\mathrm{PS}]_{0}=$ $2.5 \mathrm{mmol} \mathrm{L}^{-1}$. Error bars are not included since they are smaller than the symbols........28

Figure 8. AMZ (-ם-, left side) degradation by $\mathrm{Fe}(\mathrm{III}) / \mathrm{UVA}$ system $\left(k_{\mathrm{obs}}=0.04 \pm 4.8 \times 10^{-}\right.$ $\left.{ }^{4} \mathrm{~min}^{-1}\right)$ and $[\mathrm{Fe}(\mathrm{II})](-\triangle$-, right side) measurement during the reaction. Experimental conditions: $[\mathrm{AMZ}]_{0}=(41.4 \pm 8) \mu \mathrm{mol} \mathrm{L}{ }^{-1},[\mathrm{Fe}(\mathrm{III})]_{0}=0.134 \mathrm{mmol} \mathrm{L}^{-1}$, free $\mathrm{pH} \ldots \ldots \ldots \ldots . .29$

Figure 9. Effect of different Fe(III) complexes: Fe(III)-aqua complex (- $\square$-); $\mathrm{Fe}(\mathrm{III})$ oxalate (-口-); $\mathrm{Fe}(\mathrm{III})$-citrate (-O-); Fe(III)-tartrate (- -) $^{-}$on (A) AMZ degradation promoted by the PS/UVA system and (B) Fe(II) concentration along the reaction time. Experimental conditions: $[\mathrm{AMZ}]_{0}=(41.4 \pm 8) \mu \mathrm{mol} \mathrm{L}{ }^{-1},[\mathrm{PS}]_{0}=2.5 \mathrm{mmol} \mathrm{L}^{-1},[\mathrm{Fe}(\mathrm{III})]=$ $0.1 \mathrm{mmol} \mathrm{L}{ }^{-1}, \mathrm{Fe}(\mathrm{III}):$ ligand ratio: $1 \mathrm{Fe}(\mathrm{III}): 3$ oxalato, $1 \mathrm{Fe}(\mathrm{III}): 2$ citrate, and $1 \mathrm{Fe}(\mathrm{III}): 1$ tartrate, free $\mathrm{pH}$. Error bars are not included since they are smaller than the symbols.....32

Figure 10. Displacement of the original two-factor Doehlert design for the Fe $\mathrm{F}^{\mathrm{III}}$-oxalate

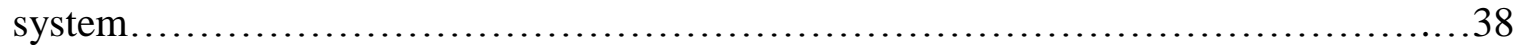

Figure 11. (A) Response surface including the experimental points (pink dots) and (B) contour plot for $k_{\mathrm{obs}}$, varying the $\mathrm{Fe}(\mathrm{III})$ :oxalate ratio from 0 to $1: 11$ and $\mathrm{pH}$ from 3.5 to

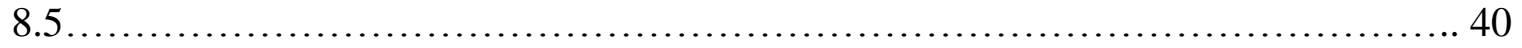

Figure 12. (A) Response surface including the experimental points (pink dots) and (B) contour plot for $k_{\mathrm{obs}}$, varying the $\mathrm{Fe}(\mathrm{III})$ :citrate ratio from 0 to $1: 5$ and $\mathrm{pH}$ from 3.5 to

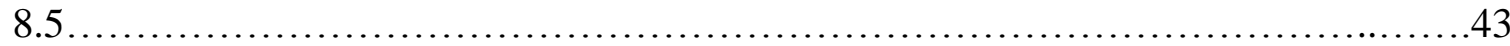

Figure 13. Effect of $\mathrm{Fe}(\mathrm{III})$ :tartrate ratio concentration on AMZ degradation profile. $(\star)$

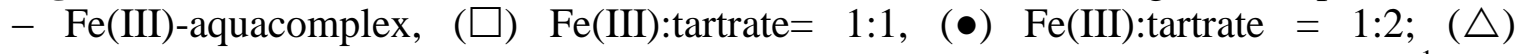
$\mathrm{Fe}(\mathrm{III}):$ tartrate $=1: 4,(\nabla) \mathrm{Fe}(\mathrm{III}):$ tartrate $=1: 10 .[\mathrm{AMZ}]_{0}=(41.4 \pm 8) \mu \mathrm{mol} \mathrm{L} \mathrm{L}^{-1}$ and

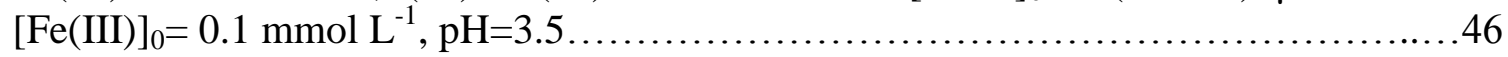

Figure 14. (A) Response surface including the experimental points (pink dots) and (B) contour plot for $\mathrm{k}_{\mathrm{obs}}$, varying the $\mathrm{Fe}(\mathrm{III})$ :tartrate ratio from 0 to $1: 5$ and $\mathrm{pH}$ from 3.5 to

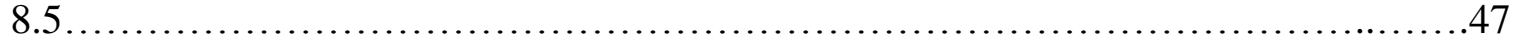


Figure 15. Formation of $\mathrm{Fe}(\mathrm{II})$ ( $\boldsymbol{\square}$, left scale, during AMZ degradation) and ${ }^{\circ} \mathrm{OH}(\triangle$ right scale, in the presence of bezene) from irradiated $\mathrm{Fe}(\mathrm{III})$-aquacomplex at $\mathrm{pH} 3.5$. $[\mathrm{AMZ}]_{0}=41.4 \mu \mathrm{mol} \mathrm{L}{ }^{-1}$ and $[\mathrm{Fe}(\mathrm{III})]_{0}=0.1 \mathrm{mmol}$

Figure 16. (A) $\mathrm{H}_{2} \mathrm{O}_{2}$, (B) $\mathrm{Fe}$ (II) photo-production and (C) AMZ degradation (white dots, left scale) vs. ${ }^{\circ} \mathrm{OH}$ photo-production (black dots, right scale) induced by irradiated $\mathrm{Fe}(\mathrm{III})$ oxalate $\left(0.1: 1 \mathrm{mmol} \mathrm{L}^{-1}\right)$ (square symbol), Fe(III)-citrate $\left(0.1: 0.4 \mathrm{mmol} \mathrm{L}^{-1}\right.$ ) (triangle symbol) and $\mathrm{Fe}(\mathrm{III})$-tartrate $\left(0.1: 0.1 \mathrm{mmol} \mathrm{L}^{-1}\right)($ circle symbol $) .[\mathrm{AMZ}]_{0}=(41.4 \pm 8)$ $\mu \mathrm{mol} \mathrm{L}{ }^{-1} ; \mathrm{pH}=3.5$

Figure 17. Comparison between AMZ degradation promoted by A1) $\mathrm{Fe}(\mathrm{III})$-oxatale (1:10), B1) $\mathrm{Fe}(\mathrm{III})$-citrate $(1: 4)$ and $\mathrm{C} 1) \mathrm{Fe}(\mathrm{III})$-tartrate $(1: 1)$ photolysis in deionized water and real water, for 1:10 (Fe(III):oxalate), 1:4 (Fe(III):citrate), and 1:1 (Fe(III):tartrate). A2), B2) and C2) correspond to the same experiments in real water, but varying $\mathrm{pH}$. D) $\mathrm{Fe}(\mathrm{III})$-aquacomplex photolysis in deionized water and real water at $\mathrm{pH}$ 3.5. In all the experiments, $[\mathrm{AMZ}]_{0}=(41.4 \pm 8) \mu \mathrm{mol} \mathrm{L}{ }^{-1} ;[\mathrm{Fe}]_{0}=0.1 \mathrm{mmol} \mathrm{L}^{-1} \ldots \ldots \ldots . .54$

Figure 18. Microtox equipment and suplies (adapted from Microtox ${ }^{\circledR}$ test protocol)....61

Figure 19. Picture of the Protoxkit $F$ and its contents

Figure 20. C. vulgaris culture growth system

Figure 21. Emission spectrum of the lamps used in the microalgae growth system

Figure 22. Pictures of E. coli and B.subtillis culures and microtiter plate where the toxicity tests regarding these bacteria were performed. .64

Figure 23. Acute toxicity evaluation of an AMZ solution before (navy bar, time 0 min) and after (green bar, time $60 \mathrm{~min}$; stripped bar, time $120 \mathrm{~min}$ ) different AOPs, towards $V$. fischeri. $\mathrm{Fe}(\mathrm{III})-\mathrm{OX}$ : $\mathrm{Fe}(\mathrm{III})$-oxalate complex; $\mathrm{Fe}(\mathrm{III})-\mathrm{CIT}$ : $\mathrm{Fe}(\mathrm{III})$-citrate complex; Fe(III)-TART: Fe(III)-tartrate complex.

Figure 24. Chronic toxicity evaluation of an AMZ solution before (navy bar, time 0 min) and after (green bar, time $60 \mathrm{~min}$; stripped bar, time $120 \mathrm{~min}$ ) different AOPs, to $C$. vulgaris microalgae. Algae death is observed when growth inhibition $>100 \%$, while trophic effect is observed when growth inhibition < 0\%. Fe(III)-OX: $\mathrm{Fe}$ (III)-oxalate complex; Fe(III)-CIT: Fe(III)-citrate complex; Fe(III)-TART: Fe(III)-tartrate complex 
Figure 25. Chronic toxicity evaluation of an AMZ solution before (navy bar, time 0 min) and after (green bar, time $60 \mathrm{~min}$; stripped bar, time $120 \mathrm{~min}$ ) different AOPs, towards $T$. termophila. Fe(III)-OX: Fe(III)-oxalate complex; Fe(III)-CIT: Fe(III)-citrate complex; Fe(III)-TART: Fe(III)-tartrate complex. .70

Figure 26. Antimicrobial activity evaluation of an AMZ solution before (navy bar, time 0 $\mathrm{min}$ ) and after (green bar, time $60 \mathrm{~min}$; stripped bar, time $120 \mathrm{~min}$ ) different AOPs, towards B. subtilis. Fe(III)-OX: Fe(III)-oxalate complex; Fe(III)-CIT: Fe(III)-citrate complex; Fe(III)-TART: Fe(III)-tartrate complex.... 72

Figure 27. (A) Influence of ZVI source and size on AMZ degradation by the PS/ZVI system (1:1);(B) Fe(II) released from PS/ZVI (1:1) experiments with micro ZVI, Nanofer 25 and nano ZVI, respectively . $[\mathrm{AMZ}]_{0}=(41.4 \pm 8) \mu \mathrm{mol} \mathrm{L}{ }^{-1} ;[\mathrm{ZVI}]_{0}=1 \mathrm{mmol} \mathrm{L}^{-1}$; $[\mathrm{PS}]_{0}=1 \mathrm{mmol} \mathrm{L}^{-1}$; free $\mathrm{pH} ; \mathrm{pH}_{0} \approx 3$. .77

Figure 28. Effect of $[\mathrm{ZVI}]_{0}$ on $(\mathrm{A}) \mathrm{pH}$ profile over reaction $(\mathrm{B}) \mathrm{Fe}^{2+}$ release during reaction; (C) AMZ degradation by the PS/ZVI system. $[\mathrm{AMZ}]_{0}=(41.4 \pm 8) \mu \mathrm{mol} \mathrm{L}^{-1}$;

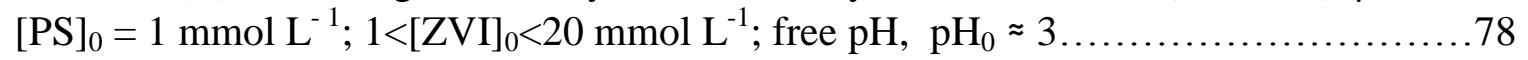

Figure 29. Effect of $[\mathrm{PS}]_{0}$ on (A) $\mathrm{AMZ}$ degradation and (B) $\mathrm{Fe}^{2+}$ concentrations at the end of 120 minutes of reaction. $[\mathrm{AMZ}]_{0}=(41.4 \pm 8) \mu \mathrm{mol} \mathrm{L}^{-1} ;[\mathrm{ZVI}]_{0}=5 \mathrm{mmol} \mathrm{L}^{-1}$; $0.5<[\mathrm{PS}]_{0}<2.5 \mathrm{mmol} \mathrm{L}^{-1}$; free $\mathrm{pH}$. $\mathrm{pH}_{0} \approx 3$.

Figure 30. Effect of solution $\mathrm{pH}$ on AMZ degradation by the PS/ZVI system, for PS/ZVI ratios of (A) 1:1 and (B) 2.5:5. [AMZ $]_{0}=(41.4 \pm 8) \mu \mathrm{mol} \mathrm{L}^{-1}$..... .80

Figure 31. (A1) Influence of dissolved oxygen on AMZ degradation by the PS/ZVI system $\left(1: 1 \mathrm{mmol} \mathrm{L}^{-1}\right)$ in the dark or (B1) in the presence of UVA radiation; (A2) Influence of dissolved oxygen on released $\mathrm{Fe}(\mathrm{II})$ during $\mathrm{AMZ}$ degradation in the

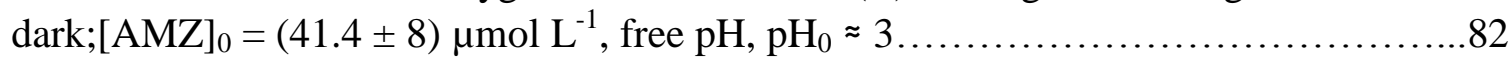

Figure 32. Influence of different water matrices on $A M Z$ degradation by the PS/ZVI system, for PS/ZVI ratios of (A) $1: 1$ and (B) $2.5 / 5$. [AMZ $]_{0}=(41.4 \pm 8) \mu \mathrm{mol} \mathrm{L}^{-1}$, free

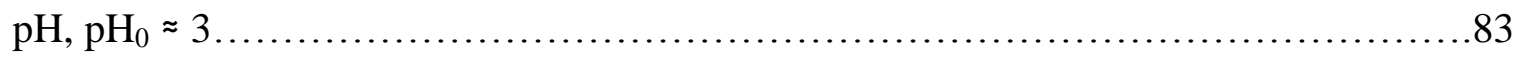

Figure 33. Proposed pathways for the reductive dehalogenation in anoxic $\mathrm{Fe}^{0}-\mathrm{H}_{2} \mathrm{O}$

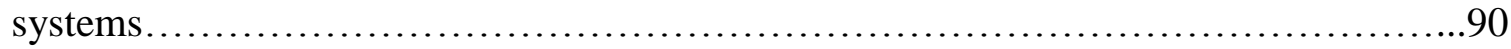

Figure 34. Schematic permeable reactive barrier (PBR) for in situ treatment with ZVI of groundwater containing halocarbons (adapted from Pereira and Ferreira 2005)........91

Figure 35.(A)SEM-FEG image $[\times 50,000]$ of $n Z V I$

Figure 35 (cont.). (B) SEM-FEG image $[\times 4,000]$ of $\mathrm{Zn} / \mathrm{Cu}$; (C) SEM-FEG image[x 1,500] of micro Fe/Cu; (D) SEM-EDS image $[\times 420]$ of $\mathrm{Cu}^{0}$ (E) SEM-EDS image $[\times$ 9300] of $\mathrm{Zn}^{0}$; (F) SEM-EDS image [ $\times$ 990] of micro ZVI; (G) SEM-FEG image [ $\times$ $50,000]$ of $n Z \mathrm{VI} / \mathrm{Cu}^{0}$.

Figure 36. (A) EDS of nZVI; (B) EDS of Zn/Cu; (C) EDS micro ZVI/Cu .............102

Figure 36 (cont.). (D) EDS of $\mathrm{Zn}^{0}$; (E) EDS micro ZVI; (F) EDS of nZVI/Cu ........103 


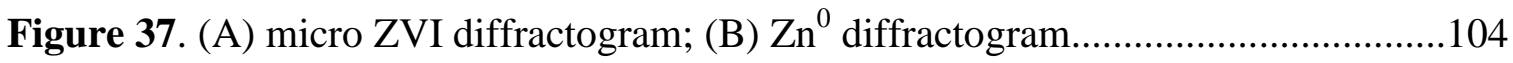

Figure 37 (cont.). (C) micro ZVI/Cu diffractogram; (D) Zn/Cu diffractogram..............105

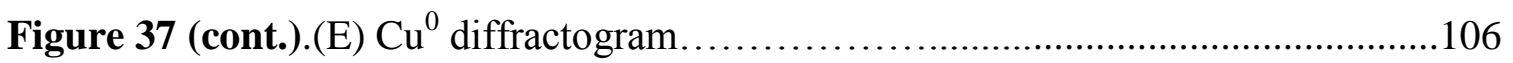

Figure 38. Effect of different (A) nZVI and (B) nZVI/Cu concentrations on chlorpyrifos

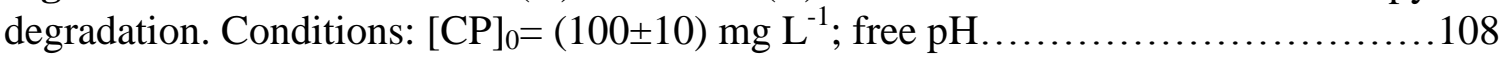

Figure 39. Chloride release as a result of chlorpyrifos dechlorination promoted by nZVI and $\mathrm{nZVI} / \mathrm{Cu}$. Conditions: $[\mathrm{CP}]_{0}=(100 \pm 10) \mathrm{mg} \mathrm{L}^{-1} ;[\mathrm{nZVI}]_{0}=[\mathrm{nZVI} / \mathrm{Cu}]_{0}=0.5 \%(\mathrm{w} / \mathrm{V})$,

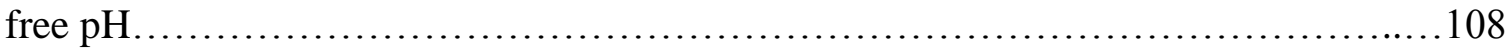

Figure 40. Comparison between the effect of different (A) monometallic and (B) bimetallic particles on chlorpyrifos degradation. Conditions: $[\mathrm{CP}]_{0}=(100 \pm 10) \mathrm{mg} \mathrm{L}^{-1}$; metals initial concentration $=0.5 \%(\mathrm{w} / \mathrm{V})$; free $\mathrm{pH}$

Figure 41. Chloride release as a result of chlorpyrifos dechlorination promoted by monometallic and bimetallic microparticles. Conditions: $[\mathrm{CP}]_{0}=(100 \pm 10) \mathrm{mg} \mathrm{L}^{-1}$; metals initial concentration $=0.5 \%(\mathrm{w} / \mathrm{V})$, free $\mathrm{pH}$

Figure 42. First-order kinetics adjustments for chlorpyrifos degradation. Conditions: $[\mathrm{CP}]_{0}=100 \mathrm{mg} \mathrm{L}^{-1}$; metals initial concentration $=0.5 \%(\mathrm{w} / \mathrm{V})$, free $\mathrm{pH}$.

Figure 43. Influence of copper particles pre-exposure to reaction medium on chlorpyrifos degradation. Conditions: $[\mathrm{CP}]_{0}=(100 \pm 10) \mathrm{mg} \mathrm{L}^{-1}$; metals initial concentration $=0.5 \%$ $(\mathrm{w} / \mathrm{V})$; free $\mathrm{pH}$.

Figure 44. Influence of previous acid washing in (A) micro ZVI particles and (B) Zn particles on chlorpyrifos degradation. $[\mathrm{CP}]_{0}=(100 \pm 10) \mathrm{mg} \mathrm{L}^{-1}$; metals initial

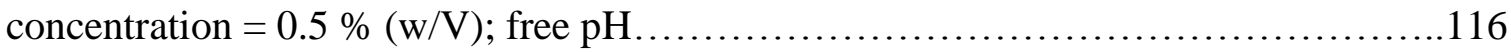

Figure A1. UVA lamp spectrum obtained through a spectoradiometer.................145

Figure A2. Standard curve for ferrioxalate actinometry........................... 146

Figure A3. Photo generated $\mathrm{Fe}(\mathrm{II})$......................................... 147

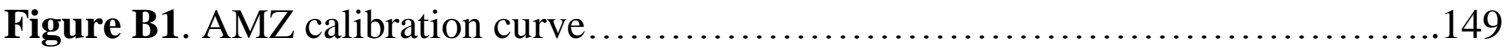

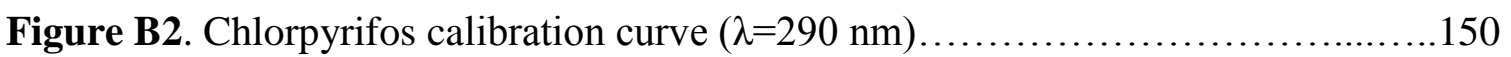

Figure C1. AMZ degradation profile for (A1) $\mathrm{pH} 7,[\mathrm{AMZ}]_{0}=41.4 \mu \mathrm{mol} \mathrm{L} \mathrm{L}^{-1}, 0.25<[\mathrm{PS}]$

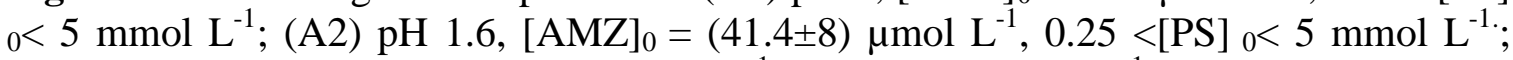

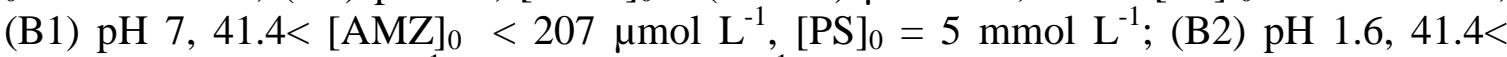
$[\mathrm{AMZ}]_{0}<207.2 \mu \mathrm{mol} \mathrm{L}^{-1},[\mathrm{PS}]_{0}=5 \mathrm{mmol} \mathrm{L}^{-1}$

Figure D1. Comparison between AMZ absorption spectrum and the emission spectrum of UVA lamps 
Figure D2. Comparison between Fe(IIII)-aquacomplex absorption spectrum and UVA lamps emission spectrum..................................................... 153

Figure D3. AMZ normalized absorption spectrum in the presence of (A) $\mathrm{Fe}$ (II), (B) $\mathrm{Fe}(\mathrm{III})$, (C) $\mathrm{Fe}(\mathrm{III})$-oxalate complex, (D) $\mathrm{Fe}$ (III)-citrate complex, (E) $\mathrm{Fe}$ (III)-tartrate complex. $[\mathrm{Fe}]_{0}=0.1 \mathrm{mmol}$, excess of ligand was used to ensure the complex formation and detection. 154

Figure D4. Comparison between Fe(III)-carboxylates absorption spectrum and UVA lamps emission spectrum. $[\mathrm{Fe}]_{0}=0.1 \mathrm{mmol}$, excess of ligand was used to ensure the complex formation and detection. 155

Figure E1. Scheme of the automated $\mathrm{pH}$ control system ............................ 156

Figure F1. Pareto Chart for Fe(III)-oxalate system before displacement.............157

Figure F2. Pareto Chart for Fe(III)-oxalate system after displacement................157

Figure. F3. Fe(III)-oxalate complex speciation................................ 158

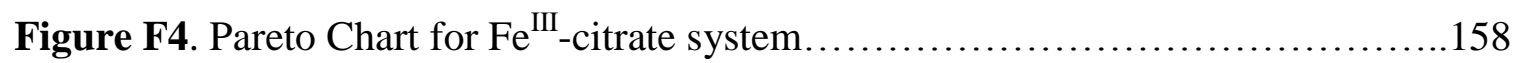

Figure F5. Fe(III)-citrate complex speciation..................................159

Figure F6. Pareto Chart for Fe(III)-tartrate system..............................159

Figure F7. Fe(III)-tartrate complex speciation................................... 160

Figure H1. Chlorpyrifos chromatograms for (A) 290 and (B) $320 \mathrm{~nm}$, stacked from 0 to 30 day degradation, promoted by $0.5 \%(w / V)$ of $\mathrm{Zn}$. 


\section{LIST OF TABLES}

Table 1. Classes of Pesticides (Adapted from EPA, 2015c).........................03

Table 2. Physical and Chemical properties of AMZ ................................06

Table 3. Chlorpyrifos concentration levels above European safety standards, detected in natural waterbodies

Table 4. Summary of recent researches where persulfate was applied to degrade pesticides in water.... .14

Table 5. Chemical and Physical properties of sodium persulfate (adapted from Block, 2006)

Table 6. Values of $k_{\mathrm{obs}}$ for the UVA/PS system for different $\mathrm{H}_{2} \mathrm{O}_{2}$ initial concentrations

Table 7. Doehlert design for two variables with $\mathrm{c}=3$.

Table 8. Doehlert design matrix for two factors and experimental values of $\mathrm{k}_{\mathrm{obs}}$ for the $\mathrm{Fe}(\mathrm{III})$-oxalate system in the presence of $[\mathrm{AMZ}]_{0}=41.4 \mu \mathrm{mol} \mathrm{L} \mathrm{L}^{-1}$ and $[\mathrm{Fe}(\mathrm{III})]_{0}=0.1$ mmol L ${ }^{-1}$

Table 9. Additional experiments for the Fe(III):oxalate system

Table 10. Doehlert design matrix for two factors and experimental values of $\mathrm{k}_{\mathrm{obs}}$ for the $\mathrm{Fe}(\mathrm{III})$-citrate system in the presence of $[\mathrm{AMZ}]_{0}=41.4 \mu \mathrm{mol} \mathrm{L}^{-1}$ and $[\mathrm{Fe}(\mathrm{III})]_{0}=0.1$ mmol L ${ }^{-1}$

Table 11. Doehlert design matrix for two factors and experimental values of $\mathrm{k}_{\mathrm{obs}}$ for the $\mathrm{Fe}(\mathrm{III})$-tartrate system in the presence of $[\mathrm{AMZ}]_{0}=41.4 \mu \mathrm{mol} \mathrm{L}^{-1}$ and $[\mathrm{Fe}(\mathrm{III})]_{0}=0.1$ mmol L ${ }^{-1}$

Table 12. Quantum yield of production of $\mathrm{Fe}(\mathrm{II})(\phi(+\mathrm{Fe}(\mathrm{II}))$ and rate of reaction in Eq.20 for each Fe(III):carboxylate complex studied.

Table 13. AMZ percent removals after the ${ }^{\circ} \mathrm{OH}-$ driven and $\mathrm{SO} 4^{\circ-}$-driven AOPs. .65

Table 14. Effect of 2-propanol and TBA on AMZ degradation by the PS/ZVI system, for PS/ZVI ratios of $1: 1$ and 2.5:5 $\left(\mathrm{mmol} \mathrm{L}^{-1}\right)$, in the absence and presence of UVA radiation. . .84

Table 15. Zero-valent metals used in chlorpyrifos degradation. .94

Table 16. Particles size based on SEM images and surface area obtained from BET analysis. 
Table 17. Average $\mathrm{k}_{\mathrm{obs}}$ and $\mathrm{k}_{\mathrm{SA}}$ values calculated for each metal studied at $0.5 \mathrm{~g} \mathrm{~L}^{-1} \ldots 113$

Table 18. Mass measurements $(\mathrm{m} / \mathrm{z})$ determined by LC/ESI(+)-IT-TOF and LC/ESI(-)IT-TOF of chlorpyrifos degradation products....

Table 18 (cont.). Mass measurements (m/z) determined by LC/ESI(+)-IT-TOF and

LC/ESI(-) -IT-TOF of chlorpyrifos degradation products 118

Table 19. Identified products for each metal tested

Table A1. Absorbance of standard solutions for $\mathrm{Fe}(\mathrm{II})$ determination via ferrioxalate actinometry 146

Table A2. Actinometry results. 147

Table B1. Measurements for AMZ calibration curve on HPLC. 149

Table B2. AMZ concentrations used for LOD and LOQ calculations 149

Table B3. Measurements for chlorpyrifos calibration curve on HPLC. 150

Table B4. Chlorpyrifos concentrations used for LOD and LOQ calculations .151

Table F1. Analysis of variance for $\mathrm{k}_{\mathrm{obs}}-\mathrm{Fe}(\mathrm{III})$ :oxalate system before displacement...157

Table F2. Analysis of variance for $\mathrm{k}_{\mathrm{obs}}-\mathrm{Fe}(\mathrm{III})$ :oxalate system after displacement....158

Table F3. Analysis of variance for $\mathrm{k}_{\mathrm{obs}}-\mathrm{Fe}(\mathrm{III})$ :citrate system. 159

Table F4. Analysis of variance for $\mathrm{k}_{\mathrm{obs}}-\mathrm{Fe}(\mathrm{III})$ :tartrate system. 160

Table F5. Relative reactivity Fe(III)-carboxylate/Fe(III)-aquacomplex .160

Table G1. WC Medium Composition (ANDERSEN R., 2005). 161 


\section{ABREVIATIONS}

A.U. Arbitrary Unit

AMZ Amicarbazone

AAS Atomic Absorption Spectrometry

ABNT Associação Brasileira de Normas Técnicas

ANOVA Analysis of Variance

AOPs Advanced Oxidation Processes

ATCC American Type Culture Collection

BET Brunauer Emmett Teller

CBZ Carbamazepine

CDL Curved Line Dissolvation

CFU Colony Forming Unit

CID Collision-Induced Dissociation

CMC Carboxymethyl Cellulose

CONAMA Brazilian National Environmental Council

CP Chlorpyrifos

CPQBA Centro Pluridisciplinar de Pesquisas Químicas, Biológicas e Agrícolas

d. $\mathrm{H}_{2} \mathrm{O} \quad$ Deionized Water

DBE Double Bond Equivalent

DCA Dichloroaniline

DDT Dichlorodiphenyltrichloroethane

DETP Diethylthiophosphate

DOC Dissolved Organic Carbon

DPD N,N-Diethyl-P-Phenylenediamine

EDS Energy-Dispersive X-Ray Spectroscopy

EDTA Ethylenediamine Tetraacetic Acid

EPA U.S Environment Protection Agency

ESI Electrospray Ionization

Fe(III)-CIT Fe(III)-Citrate Complex

$\mathrm{Fe}(\mathrm{III})-\mathrm{OX} \quad \mathrm{Fe}(\mathrm{III})-\mathrm{Oxalate}$ Complex 


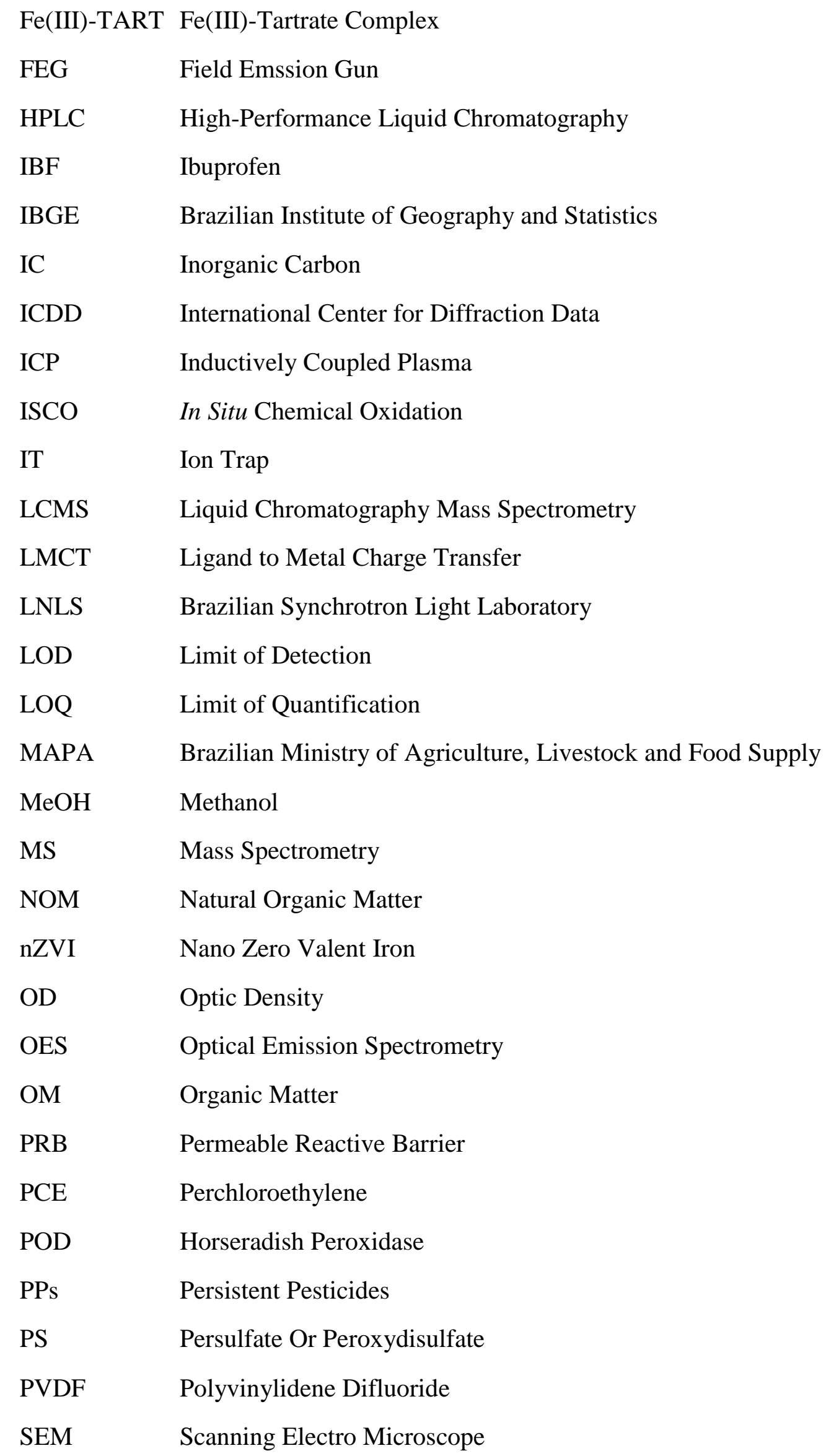


TBA Tert-Butyl Alcohol

TCE Trichloroethylene

TCP 3,5,6-Trichloro-2-Pyridinol

TOC Total Organic Carbon

TOF Time-Of-Flight Mass Analyzer

UV Ultraviolet Radiation

UVA Ultraviolet Radiation Type A

UVC Ultraviolet Radiation Type C

VOCs Volatile Organic Compounds

WFD Water Framework Directive

XAFS1 X-Ray Absortion Fine Structure I

XAS X-Ray Absorption Spectroscopy

XRD X-Ray Diffraction

ZVI Zero-Valent-Iron

ZVM Zero-Valent Metals 


\section{NOMENCLATURE}

$\begin{array}{lll}\Delta \mathrm{H}^{0} & \text { Standard entalphy of reaction } & \mathrm{Kj} \mathrm{mol}^{-1} \\ \mathrm{pKa} & \text { Acid dissociation constant } & - \\ k_{\mathrm{obs}} & \text { Observed first-order rate constant } & \mathrm{min}^{-1} \mathrm{or} \mathrm{day}^{-1} \\ k_{\mathrm{SA}} & \text { Surface area normalized rate constant } & \mathrm{L} \mathrm{day}^{-1} \mathrm{~m}^{-2} \\ \mathrm{k}_{30 \text { min }} & \begin{array}{l}\text { Observed first-order rate constant for the first } 30 \text { minutes of } \\ \text { reaction }\end{array} & \mathrm{min}^{-1} \text { or day }^{-1} \\ E^{0} & \text { Standard electrode potential } & \mathrm{V} \\ \lambda & \text { Wavelength } & \mathrm{nm} \\ \Phi & \text { Quantum yield } & - \\ I & \text { Growth inhibition } & \% \\ A_{0} & \text { Control sample absorbance } & - \\ A & \text { Absorbance } & - \\ \rho_{\mathrm{m}} & \text { Mass concentration } & \mathrm{g} \mathrm{L}^{-1} \\ a_{s} & \text { Specific surface area } & \mathrm{m}^{2} \mathrm{~g}^{-1} \\ \Delta \mathrm{OD} & \text { Difference between the Optical Density at to and } \mathrm{t}_{24} & - \\ \varepsilon & \text { Absorptivity } & \mathrm{L} \mathrm{mol}^{-1} \mathrm{~cm}^{-1}\end{array}$





\section{CONTENTS}

INTRODUCTION

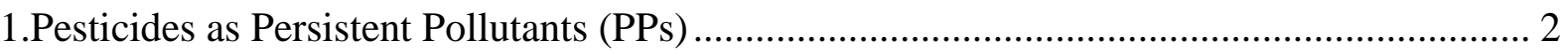

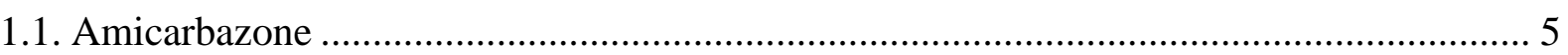

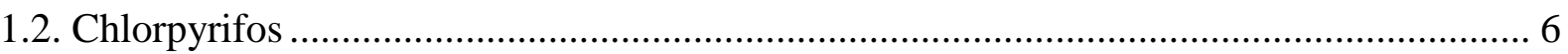

\section{CHAPTER I}

DEGRADATION OF PERSISTENT PESTICIDES VIA ADVANCED OXIDATION PROCESSES

2. Water remediation via Advanced Oxidation Processes .............................................. 10

2.1. Persulfate Activation: a novel AOP to degrade pesticides ............................................ 13

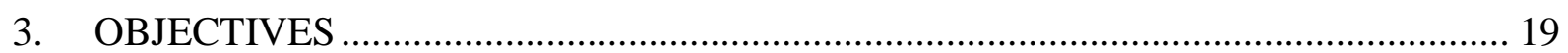

4. AMICARBAZONE DEGRADATION BY UVA-ACTIVATED PERSULFATE IN

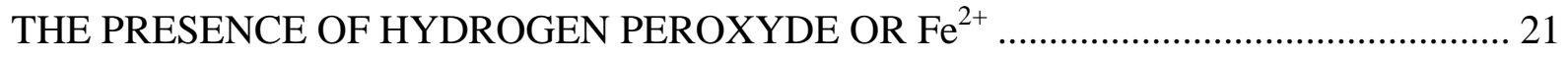

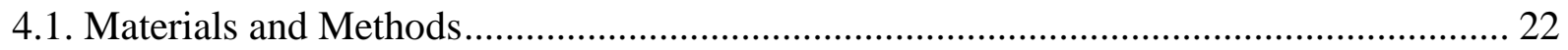

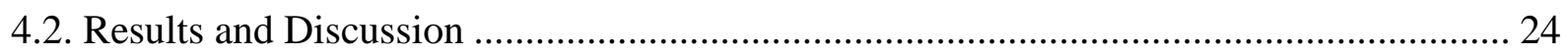

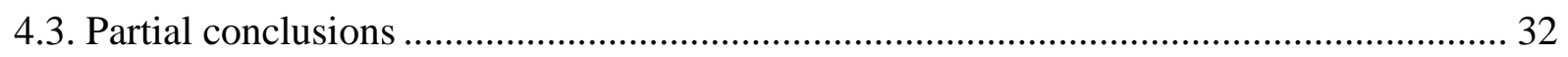

5. THE ROLE OF FE(III)-CARBOXYLATES IN AMZ PHOTODEGRADATION: A RESPONSE SURFACE STUDY BASED ON A DOEHLERT EXPERIMENTAL

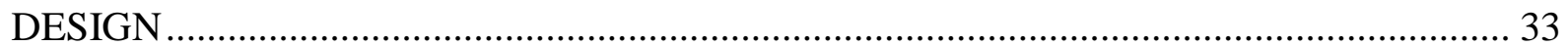

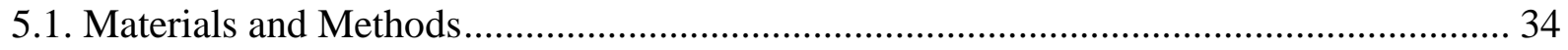

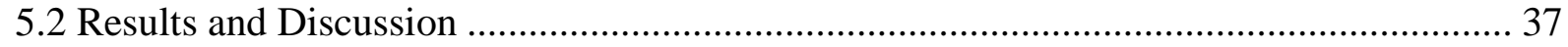

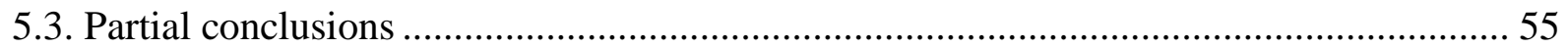

6. EVALUATION OF AMICARBAZONE TOXICITY REMOVAL THROUGH

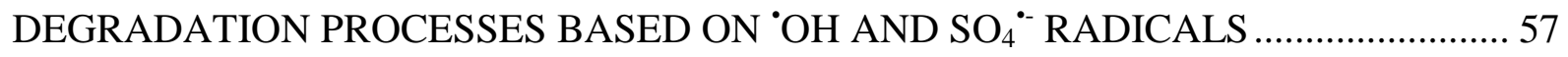

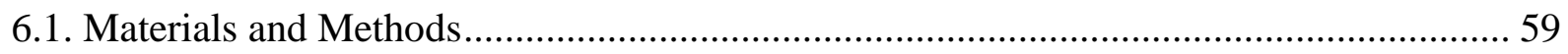

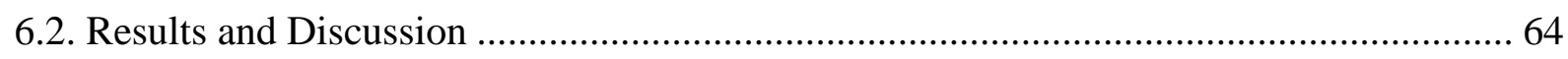

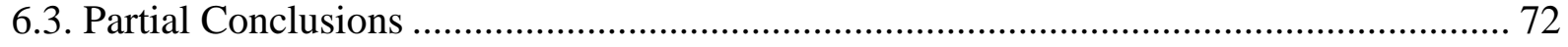

7. AMICARBAZONE DEGRADATION PROMOTED BY ZVI-ACTIVATED PERSULFATE: STUDY OF RELEVANT VARIABLES FOR PRACTICAL

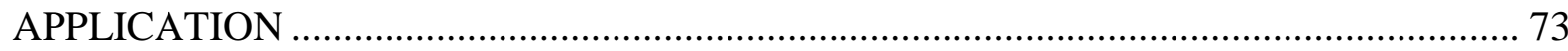

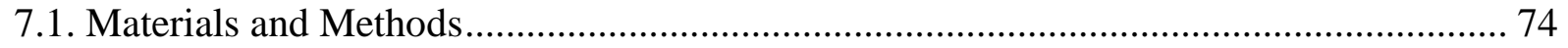

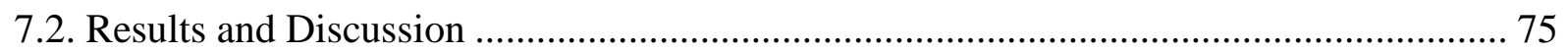




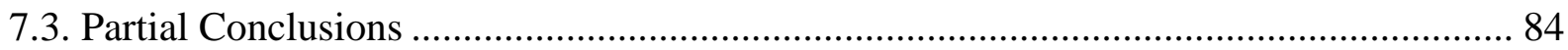

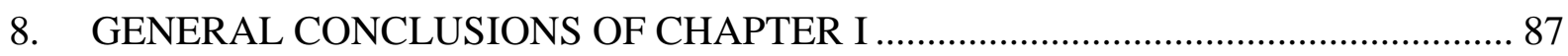

\section{CHAPTER II}

DEGRADATION OF PERSISTENT PESTICIDES VIA REDUCTIVE PROCESSES

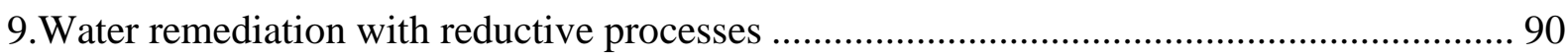

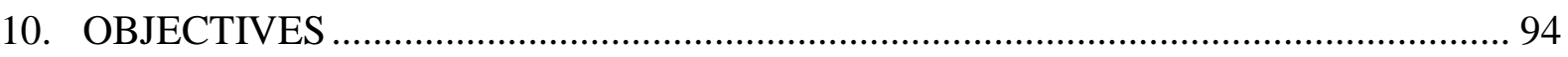

11. ANAEROBIC DEGRADATION OF CHLORPYRIFOS BY ZERO-VALENT MONOMETALLIC AND BIMETALLIC PARTICLES IN SOLUTION............................ 95

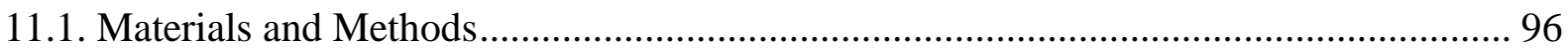

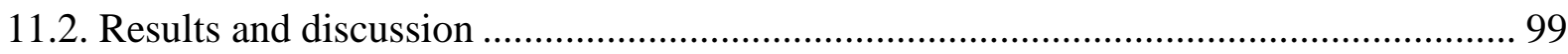

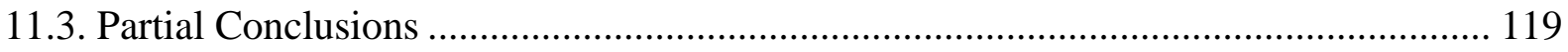

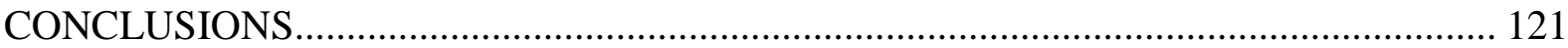

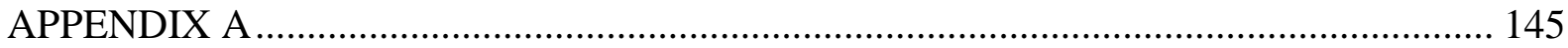

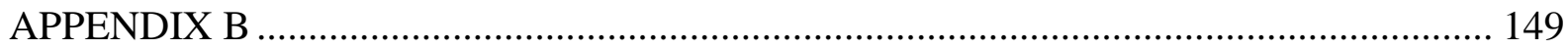

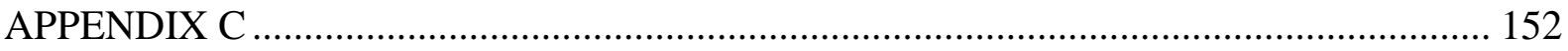

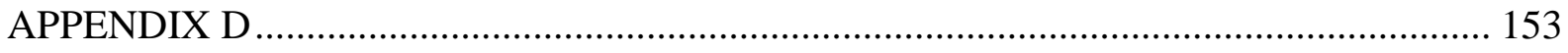

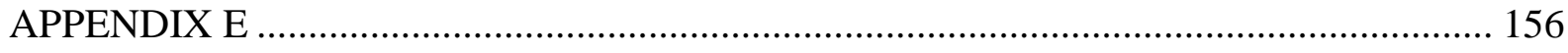

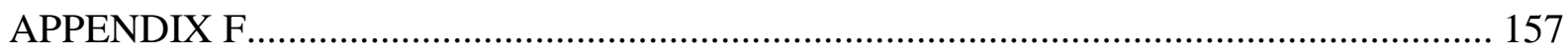

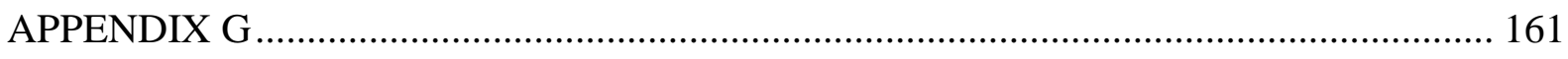

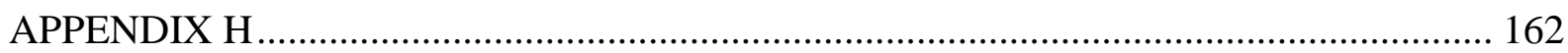


INTRODUCTION 


\section{Pesticides as Persistent Pollutants (PPs)}

Pesticides are one of the main water contaminants in Brazil. Most of these chemicals are toxic and persistent in the environment and they can also be transported by wind and water to far distances from their original source of application, representing a threat to living species around the world. To address this global concern, the United States joined forces with ninety other countries (Brazil inclusive) and European Community to sign a groundbreaking United Nations treaty, known as Stockholm Convention, in order to reduce or eliminate the production, use and/or release of Persistent Pollutants (PPs). At European level, the Water Framework Directive (WFD) has been in place as the main European legislation for the protection of water resources and water environment, since 2000. This management includes monitoring a list of priority substances that pose a particular risk to plants, animals and humans and, due to their characteristics, may accumulate in the environment over many years. Among the 33 substances set in WFD by 2008 (Annex II of Directive 2008/105/EC), twelve are pesticides (FUERHACKER, 2009).

Pesticides are often referred according to the type of pest they control. Adopting the same classification of the US Environment Protection Agency (EPA), Table 1 compiles the classes of pesticides related by the type of target pest. 
Table 1. Classes of Pesticides (Adapted from EPA, 2015c).

\begin{tabular}{|c|c|}
\hline Pesticide classification & Pesticide action \\
\hline Algicides & Control algae in lakes, canals and other sites \\
\hline Antifouling agents & $\begin{array}{l}\text { Kill or repel organisms that attach to } \\
\text { underwater surfaces, such as boat bottoms }\end{array}$ \\
\hline Antimicrobials & $\begin{array}{c}\text { Kill microorganisms (such as bacteria and } \\
\text { viruses) }\end{array}$ \\
\hline Attractants & $\begin{array}{l}\text { Attract pests (for example, to lure an insect to } \\
\text { a trap) }\end{array}$ \\
\hline Biopesticides & $\begin{array}{c}\text { Pesticides derived from natural materials such } \\
\text { as animals, plants, bacteria, and certain } \\
\text { minerals }\end{array}$ \\
\hline Biocides & Kill microorganisms \\
\hline Disinfectants and sanitizers & $\begin{array}{l}\text { Kill or inactivate disease-producing } \\
\text { microorganisms on inanimate objects }\end{array}$ \\
\hline Fungicides & Kill fungi \\
\hline Fumigants & $\begin{array}{l}\text { Produce gas or vapor intended to destroy pests } \\
\text { in buildings or soil }\end{array}$ \\
\hline Herbicides & Kill undesired weeds and other plants \\
\hline Insecticides & Kill insects and other arthropods \\
\hline Miticides & Kill mites that feed on plants and animals \\
\hline Microbial pesticides & $\begin{array}{l}\text { Microorganisms that can control different } \\
\text { kinds of pests, including other } \\
\text { microorganisms }\end{array}$ \\
\hline Molluscicides & Kill snails and slugs \\
\hline Nematicides & $\begin{array}{l}\text { Kill nematodes (microscopic, worm-like } \\
\text { organisms that feed on plant roots) }\end{array}$ \\
\hline Ovicides & Kill eggs of insects and mites \\
\hline Pheromones & $\begin{array}{l}\text { Biochemicals used to disrupt the mating } \\
\text { behavior of insects }\end{array}$ \\
\hline Repellents & Repel pests \\
\hline Rodenticides & Control mice and other rodents \\
\hline
\end{tabular}

Brazil is one of the largest agricultural producers in the world and in the last 10 years has faced a 190\% increase in the pesticide market, becoming the biggest user worldwide (RIGOTTO; VASCONCELOS; ROCHA, 2014). The most recent data available about sales of agrochemicals in Brazil indicates that herbicides represent $45 \%$ of the total consumption (Figure 1) (CARNEIRO et al., 2015). Additionally, around $31 \%$ of all herbicide expenditures in Brazil are for weed control in sugarcane cultivations 
(IBGE, 2011). In the 1940s, growers started to use the herbicide 2,4-D to control broadleaf weeds in this kind of cultivation. The use of simazine, atrazine and diuron began when grassy weeds became more troublesome. Among the most consumed herbicides in Brazil, four chemicals - ametryn, tebuthioron, and a mixture of hexazinone and diuron - stand out, as they are vastly applied in sugarcane cultivations (LEBARON et al., 2008). All of these mentioned herbicides have persistent character, which means that they do not breakdown quickly in the environment and remain for more than one growing season.

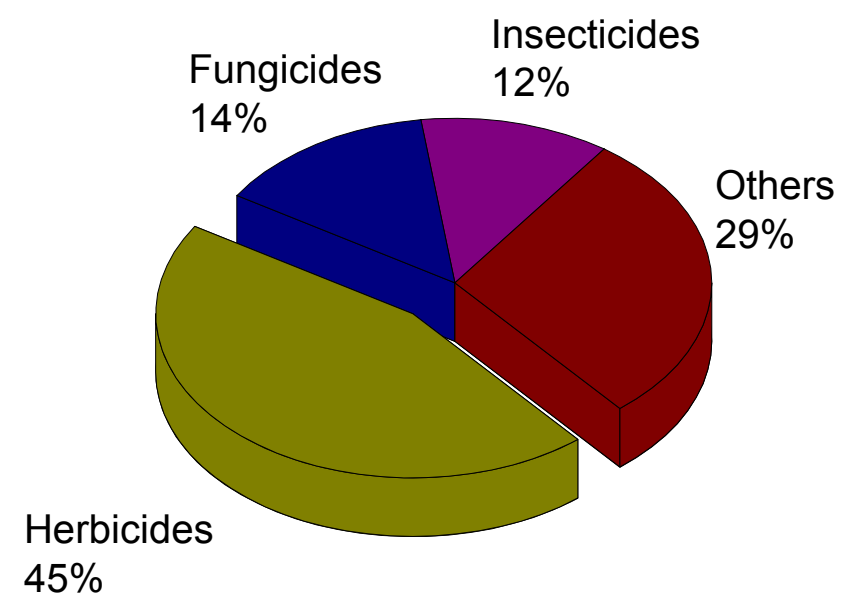

Figure 1. Pesticides sales in Brazil by type of pesticide (CARNEIRO et al., 2015)

Due to their capacity to bioaccumulate, their toxicity effect multiplies as they move up the food chain. Even when these compounds are degraded, their by-products can still pose high risk to the environment or human health. For example, diuron, an herbicide widely used against weeds in grain cultures, has a very slow rate of natural hydrolysis in a neutral solution at $25{ }^{\circ} \mathrm{C}$. However, when hydrolysis occurs, the abiotic degradation in water solution is an irreversible reaction giving 3,4-dichloroaniline (3,4-DCA) as the only product. Therefore, this byproduct is considerably more toxic than diuron itself and has higher water solubility, so it can be easily leached out from soil to ground and surface water (RATHORE et al., 2012).

Fortunately, an increasing number of countries have banned the production, selling, and usage of some persistent pesticides. Nevertheless, they can still represent a problem for the environment. Firstly, due to their continued consumption in other countries around the world, they are inevitably transported to long distances through wind 
and water after application. Secondly, due to their persistent character, they still present in the environment nowadays even if they were applied a long time ago. For example, in Canada, large amounts of persistent pesticides, such as dieldrin, chlordane, DDT and toxaphene, were used during the 1960s and 1970s. Even though these chemicals are now banned in the country, quantities of these pesticides remain in the water column of all five Great Lakes (EPA, 2015b; UWEX, 2015)

\subsection{Amicarbazone}

Brazil is one of the world's largest consumers of pesticides, particularly atrazine, an herbicide widely used in corn and sugarcane cultivations. According to the Regulation of the Brazilian National Environmental Council (CONAMA), which was approved in 2005, non-salty water bodies should be classified, regarding its noblest use, among five classes: special, 1, 2, 3 and 4. In the case the Basin Committee has not classified a certain water body, it should meet the requirements of class 2 , which does not allow atrazine concentrations higher than $2 \mu \mathrm{g} \mathrm{L} \mathrm{L}^{-1}$. However, concentrations above the maximum allowable value for this herbicide are still detected. For example, a case study developed in Tianguá (Northeast Brazil) showed that the groundwater of the area studied was contaminated with atrazine at concentrations above $10 \mu \mathrm{g} \mathrm{L}^{-1}$ (ARRAES; MAUR, 2008).

Due to the environmental and health risks associated with atrazine, such as groundwater contamination and hormonal disrupting (to vertebrate organisms), it was banished from many countries (SASS; COLANGELO, 2006). Reducing offsite movement of atrazine and/or using other products to control weeds are suitable procedures to solve problems related with atrazine contamination.

An alternative is amicarbazone (AMZ), a triazolinone herbicide introduced into the Brazilian market in 2004, by Arysta LifeScience (KRÄMER et al., 2012). Chemically referred as 4-amino-N-tert-butyl-4,5-dihydro-3-isopropyl-5-oxo-1H-1,2,4-triazole-1carboxamide or $\mathrm{C}_{10} \mathrm{H}_{19} \mathrm{~N}_{5} \mathrm{O}_{2}$, amicarbazone is also known by the commercial names Amicarbazone DF, Xonerate, and Dinamic 70 WDG. Its structural formula is shown in Figure 2.

Although AMZ presents low toxicity, it is moderately persistent in the environment due to its slow degradation by photolysis, hydrolysis and anaerobic aquatic metabolism (EPA, 2005a). Due to its low vapor pressure $\left(9.75 \times 10^{-9} \mathrm{~mm} \mathrm{Hg}\right.$ at $\left.30^{\circ} \mathrm{C}\right)$ and high water solubility (4600 ppm at $20{ }^{\circ} \mathrm{C}$ ) (Table 2) AMZ can be leached after field application, easily reaching surface or groundwater bodies. In fact, a recent study developed in 
Córrego Rico, SP (Brazil), indicated the presence of several herbicides in groundwater, including AMZ, which was detected under quantifiable levels (SANTOS; CORREIA, 2015).

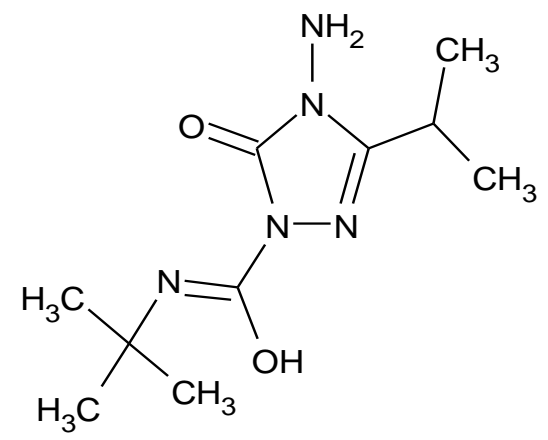

Figure 2. Structural chemical formula of amicarbazone.

Table 2. Physical and chemical properties of AMZ (Adapted from EPA, 2015a).

\begin{tabular}{cc}
\hline Molar mass $\left(\mathbf{g ~ m o l}^{-\mathbf{1}}\right)$ & 241.3 \\
\hline Density $\left(\mathbf{g ~ c m}^{\mathbf{3}}\right)$ & 1.12 \\
\hline Aspect & White crystals \\
\hline Melting point $\left({ }^{\mathbf{0}} \mathbf{C}\right)$ & 137.5 \\
\hline Vapor pressure $(\mathbf{P a})$ & $1.3 \times 10^{-6}\left(20^{\circ} \mathrm{C}\right)$ \\
\hline Water solubility at $\mathbf{2 0}{\mathbf{~ C ~}\left(\mathbf{m g ~ L}^{-1}\right)}^{\circ}$ & $3.0 \times 10^{-6}\left(25^{\circ} \mathrm{C}\right)$ \\
\hline
\end{tabular}

Owing to its characteristics and extensive use, AMZ may represent a risk to animals as well as to the environment, turning emergent the need of developing remediation techniques capable to treat AMZ-contaminated water and wastewater.

\subsection{Chlorpyrifos}

Chlorpyrifos (CP) is a chlorinated organophosphorus insecticide (Figure 3) worldwide used in agriculture and residential pest control. It is available in various formulations under the trade names such as Lorsban, Pyrinex, Spannit, Tricel, Dursban, Piridane, Silrifos, and Talon, being effective against a broad spectrum of insect pests on a variety of cultivations, like grain, cotton, fruit, nut, and others (REDDY et al., 2013). Similarly to other organophosphorus pesticides, its insecticidal action includes the inhibition of the enzyme acetyl cholinesterase, which can also cause a potential risk to humans and other organisms' health. Actually, there is a study confirming that exposure to $\mathrm{CP}$ for long periods results in serious harm to the human nervous system, respiratory tract, and cardiovascular systems (SINHA et al., 2006). Although it has low water 
solubility $\left(2 \mathrm{mg} \mathrm{L}^{-1}\right)$, after field application the pesticide can be leached, reaching surface and groundwater bodies (RACKE; LASKOWSKI; SCHULTZ, 1990).

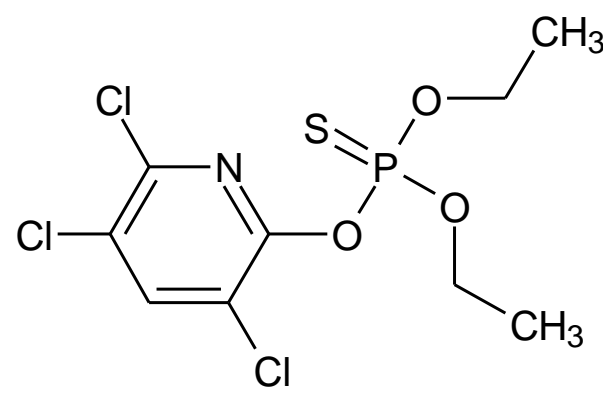

Figure 3. Chemical structure of chlorpyrifos.

Table 3 lists some studies reporting alarming CP concentrations detected in waterbodies. In fact, EPA proposed to ban this insecticide since the concentrations found in drinking water may not meet safety standards $\left(<0.1 \mu \mathrm{g} \mathrm{L}^{-1}\right)(\mathrm{EPA}, 2016)$.

Table 3. Chlorpyrifos concentration levels above European safety standards, detected in natural waterbodies.

\begin{tabular}{llll}
\hline \multicolumn{1}{c}{$\begin{array}{c}\text { Detected } \\
\text { concentration }\end{array}$} & Waterbody & Country & \multicolumn{1}{c}{ Reference } \\
\hline $10.8 \mu \mathrm{g} \mathrm{L}^{-1}$ & $\begin{array}{l}\text { Surface } \\
\text { water } \\
0.44 \mu \mathrm{g} \mathrm{L}^{-1}\end{array}$ & Argentina & (MARINO; RONCO, 2005) \\
$0.25 \mu \mathrm{g} \mathrm{L}^{-1}$ & $\begin{array}{l}\text { Surface and } \\
\text { ground } \\
\text { water }\end{array}$ & India & (LARI et al., 2014) \\
$9.31 \mu \mathrm{g} \mathrm{L}^{-1}$ & $\begin{array}{l}\text { Surface } \\
\text { water }\end{array}$ & Bangladesh & (HOSSAIN et al., 2014) \\
\hline
\end{tabular}

The presence of CP was also detected in cold drinks, bottled drinking water and blood of farmers in Punjab, India (CENTRE of SCIENCE and ENVIRONMENT, 2005). Thus, more attention should be paid to the degradation of $\mathrm{CP}$ and their residues in the soil, water, and waste sites contaminated by this insecticide. Conventionally, bioremediation is a good option for the degradation of $\mathrm{CP}$, but it has several operational constraints, such as incomplete and slow rate of degradation, which could result in more harmful degradation products (KRALJ; FRANKO; TREBS, 2007).

According to the target contaminant some degradation techniques might be more suitable than others. For this reason, in this work were explored different degradation methods to remove $\mathrm{AMZ}$ and $\mathrm{CP}$ from water matrices. For the former, different advanced 
oxidation processes (AOP) were explored to achieve its degradation, which are discussed in Chapter I. Due to CP structural characteristics, reductive processes are preferred to oxidative processes, thus a different approach regarding the degradation of this pesticide is presented in Chapter II. 


\section{CHAPTER I}

\section{DEGRADATION OF PERSISTENT}

\section{PESTICIDES VIA ADVANCED OXIDATION PROCESSES}




\section{Water remediation via Advanced Oxidation Processes}

Water is known as an infinitely renewable resource, despite being a finite one. The hydrological cycle ensures a constant water replacement on Earth, but actually its consumption rate is much higher than its natural recycling, leading to the reality of water scarcity in a growing number of countries. This scenario tends to get worse due to the rapid population growth, because not only the human water consumption has increased, but also the water demand to produce goods and services. At a global level, according to statistical studies developed by the Food and Agriculture Organization of the United Nations (AQUASTAT, 2014), the water withdrawal is 69\% agricultural (including irrigation, livestock and aquaculture), 12\% industrial and 19\% municipal. These demands are associated with the inherent problem of water pollution, because either agricultural practice or industrial waste and household sewage release huge amounts of pollutants. An investigation undertaken by the Brazilian Institute of Geography and Statistics (IBGE) concluded that pesticides are the $2^{\text {nd }}$ main source of water contamination in Brazil, preceded by domestic sewage (IBGE, 2012). In fact, the extensive use of pesticides that contributes to this pollution problem is already affecting population's life and health, consisting then in a "wake-up call" to the necessity of changing the way pesticides are applied. A compromise between prevention and remediation should be achieved, but since there are already so many polluted water bodies, water remediation techniques have been receiving greater focus.

There are two types of water remediation according to where it takes place: in situ and off site. The first involves cleaning up the water supply where it is situated, rather than transporting the water to a treating unit at another location. In many cases, this option makes the remediation process less expensive. The second alternative consists in collecting wastewater which is transported to a location where the contaminants can be safely removed. This procedure has the advantage of transporting the contaminants along with the water, avoiding the further destruction of the ecological balance at the site (TATUM et al., 2015)

Nowadays, water remediation can be achieved through many different methods, such as chemical (e.g. flocculation, coagulation), physical (e.g. filtration, membrane separation) and/or biological methods (e.g. activated sludge), but these conventional techniques revealed to be insufficient when the wastewater contains recalcitrant pollutants (LOURES et al., 2013). In this context, Advanced Oxidation Processes (AOPs) appear as a promising alternative due to their high capability to degrade organic 
compounds, even those with recalcitrant character. These processes rely mainly on the formation of reactive, short-lived oxygen-containing intermediates (e.g. ${ }^{\circ} \mathrm{OH}$ and $\mathrm{SO}_{4}{ }^{-}$) with the ability to mineralize organic compounds into carbon dioxide, water, and inorganic ions or, at least, into harmless products (ANDREOZZI, 1999; OPPENLÄNDER, 2003). The most used and promising AOPs for practical applications are:

(a) Fenton and Photo-Fenton $\left(\mathrm{H}_{2} \mathrm{O}_{2} / \mathrm{Fe}^{2+}\right.$ and $\mathrm{H}_{2} \mathrm{O}_{2} / \mathrm{Fe}^{2+} / \mathrm{UV}$ and/or $\left.\mathrm{H}_{2} \mathrm{O}_{2} / \mathrm{Fe}^{3+} / \mathrm{UV}\right)$ : The Fenton reactant is an attractive oxidative system for wastewater treatment due to the fact that iron is a very abundant and considered a non-harmful element (15 $\mathrm{mg} \mathrm{L}^{-1}$ of total dissolved iron is the maximum concentration allowed in waters prior to entering sewage treatment plants in the State of São Paulo, Brazil, according to the Brazilian Directive 8468) and hydrogen peroxide is relatively easy to handle and environmentally safe. However, the Fenton process requires strict $\mathrm{pH}$ control and sludge is formed, with related disposal problems. For example, an investigation undertaken by Samet et al. (2012) showed that Fenton and solar photo-Fenton are promising processes for the degradation of the pesticide chlorpyrifos, having achieved an organic matter decay of $90 \%$.

(b) $\mathrm{H}_{2} \mathrm{O}_{2}$ photolysis $\left(\mathrm{H}_{2} \mathrm{O}_{2} / \mathrm{UV}\right)$ : Hydrogen peroxide $\left(\mathrm{H}_{2} \mathrm{O}_{2}\right)$ under ultraviolet radiation in the wavelength range $200-300 \mathrm{~nm}$ is a source of ${ }^{\circ} \mathrm{OH}$ radicals. Therefore, this feature has been extensively used in the treatment of pesticidecontaining wastewater. Vogna et al. (2004) studied the $\mathrm{UV} / \mathrm{H}_{2} \mathrm{O}_{2}$-induced degradation of carbamazepine, an antiepileptic drug recently found as a contaminant in many municipal sewage treatment plants (STP). The oxidation treatment caused a complete abatement of the drug after 4-min treatment, with $35 \%$ of the total organic carbon (TOC) removed. However, a drawback of this AOP is the small molar extinction coefficient of $\mathrm{H}_{2} \mathrm{O}_{2}$ at $254 \mathrm{~nm}\left(\varepsilon_{254 \mathrm{~nm}}=19.6 \mathrm{~L}^{-}\right.$ ${ }^{1} \mathrm{~mol}^{-1} \mathrm{~cm}^{-1}$ ) (GLAZE; KANG; CHAPIN, 1987), which means that large amounts of this oxidant are needed to achieve good results.

(c) Heterogeneous photocatalysis $\left(\mathrm{TiO}_{2} / \mathrm{UV}\right)$ : A semiconductor, such as titanium dioxide, is irradiated with UV-radiation under $387 \mathrm{~nm}$, in order to exceed its band gap energy $\left(\mathrm{E}_{\mathrm{bg}}=3.2 \mathrm{eV}\right.$ in the case of anatase $\left.\mathrm{TiO}_{2}\right)$ and excite electrons from the valence band to the conduction band. As a consequence, positive holes $\left(\mathrm{h}^{+}\right)$are 
formed in the valence band, which can react with organic molecules ( $\mathrm{RX}), \mathrm{H}_{2} \mathrm{O}$ or $\mathrm{OH}^{-}$adsorbed on the catalyst surface, leading to the formation of cationic organic $\left(\mathrm{R}^{\bullet+}\right)$ and ${ }^{\bullet} \mathrm{OH}$ radicals, respectively (Eqs. 1-3):

$\mathrm{TiO}_{2}\left(\mathrm{~h}^{+}\right)+\mathrm{H}_{2} \mathrm{O}_{\mathrm{ad}} \rightarrow \mathrm{TiO}_{2}+{ }^{\cdot} \mathrm{OH}_{\mathrm{ad}}+\mathrm{H}^{+}$

$\mathrm{TiO}_{2}\left(\mathrm{~h}^{+}\right)+\mathrm{RX}_{\mathrm{ad}} \rightarrow \mathrm{TiO}_{2}+\mathrm{RX}_{\mathrm{ad}}^{\bullet+}$

$\mathrm{TiO}_{2}\left(\mathrm{~h}^{+}\right)+\mathrm{OH}_{a \bar{d}} \rightarrow \mathrm{TiO}_{2}+{ }^{\bullet} \mathrm{OH}_{\mathrm{ad}}$

Despite the high concentration of $\mathrm{H}_{2} \mathrm{O}$ and $\mathrm{OH}^{-}$adsorbed on the catalyst surface, a significant part of electron-hole pairs recombine, thus reducing the quantum yield of this process (ANDREOZZI et al., 1999). Another disadvantage of this process is related to the separation steps required to remove the $\mathrm{TiO}_{2}$ suspension from the treated water (LAZAR; VARGHESE; NAIR, 2012). However, this disadvantage can be surpassed by immobilizing the $\mathrm{TiO}_{2}$ particles in supporting materials to facilitate its post-treatment separation, like vermiculite (JIN; DAI, 2012), glass spheres (MIRANDA-GARCIA et al., 2010), among others.

(d) Ozone based AOPs $\left(\mathrm{O}_{3} / \mathrm{UV}, \mathrm{O}_{3} / \mathrm{H}_{2} \mathrm{O}_{2}, \mathrm{O}_{3} / \mathrm{H}_{2} \mathrm{O}_{2} / \mathrm{UV}, \mathrm{O}_{3} / \mathrm{TiO}_{2} / \mathrm{UV}\right)$ : Ozone can decompose organic matter present in wastewater via two distinct mechanisms: the direct and indirect reactions. The direct reaction is already widely used in disinfection of potable water, in wastewater treatment and in many other applications (OPPENLÄNDER, 2003). Here the ozone gas is bubbled into the contaminated water stream where either organic compounds or microorganisms are attacked. The indirect reaction takes place via radicals (hydroxyl, superoxide, ozonide and hydroperoxide radicals) generated by the decomposition of ozone in alkaline conditions. Aqueous systems saturated with ozone can be irradiated with $\mathrm{UV}$ radiation at $254 \mathrm{~nm}$. The molar absorption coefficient of $\mathrm{O}_{3}$ at $254 \mathrm{~nm}$ is 3600 $\mathrm{L} \mathrm{mol}^{-1} \mathrm{~cm}^{-1}$, much higher than that of $\mathrm{H}_{2} \mathrm{O}_{2}$ (ANDREOZZI et al., 1999). Beduk and co-workers (2012) compared the degradation of malathion and parathion by ozonation, photolytic ozonation, and heterogeneous catalytic ozonation and found that only $\mathrm{O}_{3} / \mathrm{TiO}_{2} / \mathrm{UV}$ was capable to completely degrade these pesticides after 30 minutes (BEDUK; AYDIN; OZCAN, 2012). However, this kind of AOP has also limitations, mainly related with the low solubility and low stability of ozone in water (LOURES et al., 2013). 
All these AOPs make use of expensive reactants and have high operating costs, but several researches are being developed in order to achieve more effective and economical ones. For example, coupling AOPs with other treatments has proved to decrease operation costs (OLLER; MALATO; SÁNCHEZ-PÉREZ, 2011).

So far, little is known about the degradation of the herbicide amicarbazone (AMZ) via AOPs, which consists in one of the main motivations behind the studies developed in this first chapter. Peixoto et al. (2014) have reported the use of UV radiation (mainly 254 $\mathrm{nm}$ ) to degrade $\mathrm{AMZ}$ with $100 \%$ removal after 20 hours of irradiation. Also, Silva et al. (2015) studied the photochemical fate of AMZ in aqueous media and simulated its sunlight-driven degradation in water bodies of different characteristics. The authors found that the direct AMZ photolysis by sunlight is very unlikely, with herbicide half-lives varying from about less than 1 day to more than 2 months. In this way, the use of oxidants to accelerate $\mathrm{AMZ}$ degradation by means of AOPs appears as an attractive way of treating AMZ-contaminated water and wastewaters.

\subsection{Persulfate Activation: a novel AOP to degrade pesticides}

Usually, traditional Advanced Oxidation Processes are referent to hydroxyl radical-driven oxidation ( ${ }^{\circ} \mathrm{OH}-\mathrm{AOPs}$ ). All AOPs mentioned in section 2.1 are ${ }^{\circ} \mathrm{OH}-\mathrm{AOPs}$ and have been frequently studied to degrade and/or mineralize emerging organic pollutants in water, since hydroxyl radicals are highly reactive and almost unselective species (GAO et al., 2012).

In recent years, persulfate-induced AOPs (PS-AOPs) have become a popular remediation technology (PETRI et al., 2011). Upon activation, cleavage of the $\mathrm{O}-\mathrm{O}$ bond in the $\mathrm{S}_{2} \mathrm{O}_{8}{ }^{2-}$ structure results in the generation of sulfate radicals $\left(\mathrm{SO}_{4}{ }^{-*}\right)$ directly and/or ${ }^{\circ} \mathrm{OH}$ indirectly. $\mathrm{SO}_{4}{ }^{-}$have a high standard reduction potential of $2.6 \mathrm{~V}$ HSE, slightly lower than that of ${ }^{\circ} \mathrm{OH}$ (2.9 V HSE) (LIANG; GUO; PAN, 2014), it is also nonselective and can attack most of organic pollutants in water, including pesticides. Table 4 summarizes some studies in which persulfate was applied to degrade pesticides in water. 
Table 4. Summary of recent studies in which persulfate was applied to degrade pesticides in water.

\begin{tabular}{ccc}
\hline Process & Target Pesticide & References \\
\hline $\mathrm{PS}+$ heat & & \\
$\mathrm{PS}+\mathrm{Fe}(\mathrm{II})$ & $2,4-\mathrm{D}$ & LIANG; GUO; \\
$\mathrm{PS}+\mathrm{H}_{2} \mathrm{O}_{2}$ & & PAN, (2014) \\
$\mathrm{PS}+\mathrm{NaOH}$ & & JI et al., (2015) \\
\hline $\mathrm{PS}+$ heat & Atrazine & LIU et al., (2012) \\
\hline $\mathrm{PS}+\mathrm{Fe}(\mathrm{II})$ & Propachlor & \\
$\mathrm{PS}+\mathrm{Cu}(\mathrm{II})$ & & WEI et al., (2016)
\end{tabular}

Additionally, sulfate radicals can be considered an environmental friendly species due to the transformation of sulfate radicals into non-toxic sulfate anions after reaction, thus not requiring special disposal or caution. In fact, according to CONAMA regulation for class I waters, a high concentration of sulfates $\left(250 \mathrm{mg} \mathrm{L}^{-1} \mathrm{SO}_{4}{ }^{2-}\right)$ is accepted.

However, given the relatively short period of time that persulfate has been used for in situ chemical oxidation (ISCO) and the fact that persulfate is a less common oxidant in industrial processes and water treatment in comparison with hydrogen peroxide, permanganate, or ozone, there is less information available for persulfate. As a result, many questions remain regarding persulfate reaction chemistry, activation methods and contaminant treatability (PETRI et al., 2011). The following paragraphs summarize what has been reported up to date about persulfate chemistry and activation reactions used to treat contaminated waters.

\subsection{1 - Persulfate Chemistry}

Persulfate reaction chemistry can be complex, including radical chain reactions, radical scavenging, oxidation of organic compounds and competing reactions, so it is important to understand what is behind the use of this oxidant.

Persulfate is chemically denominated as peroxydissulfate and is represented by the anion $\mathrm{S}_{2} \mathrm{O}_{8}{ }^{2-}$. It is commonly supplied not only as sodium persulfate (solid salt $\mathrm{Na}_{2} \mathrm{~S}_{2} \mathrm{O}_{8}$ ), but also as ammonium persulfate and potassium persulfate solutions. Chemical and physical properties of sodium persulfate are presented in Table 5. Its structural formula is shown in Figure 4. 
Table 5. Chemical and Physical properties of sodium persulfate (adapted from Block, 2004).

\begin{tabular}{lcc}
\hline \multicolumn{1}{c}{ Property } & Value \\
\hline $\begin{array}{l}\text { Physical form } \\
\text { Molar mass }\left(\mathrm{g} \mathrm{mol}^{-1}\right)\end{array}$ & & Withe cristalline solid \\
Solubility limit & $0 \circ \mathrm{C}$ & 238.1 \\
& $25 \circ \mathrm{C}$ & $37 \mathrm{wt} . \%$ \\
& $50 \circ \mathrm{C}$ & $42 \mathrm{wt} . \%$ \\
Solution density & & $46 \mathrm{wt} . \%$ \\
$\left(\mathrm{~g} \mathrm{~mL}^{-1}\right)$ & $10 \mathrm{wt} \%$ & 1067 \\
& $20 \mathrm{wt} \%$ & 1146 \\
& $30 \mathrm{wt} \%$ & 1237 \\
& $40 \mathrm{wt} \%$ & 1340 \\
\hline & &
\end{tabular}<smiles>O=S(=O)([O-])OOS(=O)(=O)[O-]</smiles>

Figure 4. Structural chemical formula of persulfate.

\subsection{2 - Persulfate Activation}

Persulfate can directly react with the target contaminant or first be decomposed into highly reactive radicals, to further react with target molecules. This decomposition into free radicals can be activated through different mechanisms, as discussed below. The activation method should be chosen accordingly to the target, as well as to the reaction medium. For example, there can be a variety of interactions between persulfate and aquifer materials that may impact its effectiveness (PETRI et al., 2011). Different persulfate activation methods already tested for pesticide degradation are briefly discussed in the following paragraphs.

\section{i) Heat Activation}

Persulfate can be decomposed by heat into two sulfate radicals according to the reaction given by Eq. 4. Generally, when temperature increases, the rate of oxidant decomposition also increases, thus increasing the contaminant degradation.

$\mathrm{S}_{2} \mathrm{O}_{8}{ }^{2-}+$ heat $\rightarrow 2 \mathrm{SO}_{4}{ }^{--}$

Ji et al. (2015) studied the heat-activated persulfate oxidation of atrazine varying the temperature from 20 to $60{ }^{\circ} \mathrm{C}$ and found that the rate of atrazine degradation was 
enhanced as the temperature increased, achieving total herbicide degradation after 80 minutes of reaction at $60{ }^{\circ} \mathrm{C}$. This is expected, since the specific reaction rate $(k)$ is directly dependent on temperature, according to the Arrhenius law.

ii) Alkaline Activation

Alkaline activation of persulfate involves the addition of a concentrated base solution, either sodium hydroxide $(\mathrm{NaOH})$ or potassium hydroxide $(\mathrm{KOH})$, to a persulfate solution in order to raise the $\mathrm{pH}$ to a high value $(\mathrm{pH}$ 11-12). According to the investigation performed by Furman et al. (2010), the alkaline activation of persulfate involves the base-catalyzed hydrolysis of persulfate to hydroperoxide anion and sulfate, followed by the reduction of another persulfate molecule by hydroperoxide (Eqs. 6-8):

$\mathrm{S}_{2} \mathrm{O}_{8}{ }^{2-}+\mathrm{H}_{2} \mathrm{O} \stackrel{\mathrm{OH}^{-}}{\longrightarrow} \mathrm{SO}_{5}{ }^{2-}+\mathrm{SO}_{4}{ }^{2-}+2 \mathrm{H}^{+}$

$\mathrm{SO}_{5}{ }^{2-}+\mathrm{H}_{2} \mathrm{O} \stackrel{\mathrm{OH}^{-}}{\longrightarrow} \mathrm{HO}_{2}^{-}+\mathrm{SO}_{4}{ }^{2-}+\mathrm{H}^{+}$

$\mathrm{HO}_{2}^{-}+\mathrm{S}_{2} \mathrm{O}_{8}{ }^{2-} \rightarrow \mathrm{SO}_{4}{ }^{2-}+\mathrm{SO}_{4}{ }^{--}+\mathrm{H}^{+}+\mathrm{O}_{2}^{--}$

The rates of reaction of this process at high $\mathrm{pH}$ vary widely for different organic compounds. However, these rates generally increase with increasing $\mathrm{pH}$, as well as with temperature. Alkaline activation was shown by Block et al. (2004) to be very effective on halomethanes and chloroethanes (VOCs) degradation. The authors pointed out that persulfate reactivity increases with increasing the $\mathrm{KOH}$ content.

iii) Activation with transition metals

Activation of persulfate by transition metals offers the advantage of accelerating persulfate chemical reactions at room temperature and, through the use of metal-chelate complexes, at near-neutral $\mathrm{pH}$ values as well. Metal ions that have been explicitly noted to activate persulfate include $\mathrm{Fe}(\mathrm{II}), \mathrm{Fe}(\mathrm{III})$, silver [Ag(I)], and copper [Cu(II)] (PETRI et $a l ., 2011)$. However, iron-driven persulfate activation is by far the most studied, which is similar to the Fenton reaction, being also viewed as a Fenton-like process. The mechanism involves electron transfer from $\mathrm{Fe}^{2+}$ to $\mathrm{S}_{2} \mathrm{O}_{8}{ }^{2-}$, originating sulfate radicals, $\mathrm{Fe}^{3+}$ and $\mathrm{SO}_{4}{ }^{2-}$ (Eq. 9).

$\mathrm{Fe}^{2+}+\mathrm{S}_{2} \mathrm{O}_{8}{ }^{2-} \rightarrow \mathrm{Fe}^{3+}+\mathrm{SO}_{4}{ }^{2-}+\mathrm{SO}_{4}{ }^{--}$ 
Rao et al. (2014) studied the degradation of carbamazepine (CBZ) with Fe(II)activated persulfate and found that, by increasing Fe(II) dosage, CBZ degradation increased up to a certain limit, and above that, the CBZ decay rate slowed down. However, for different contaminants it is necessary to optimize different iron dosages and different $\left[\mathrm{Fe}^{2+}\right] /[\mathrm{PS}]$ ratios in order to obtain the best degradation performance.

Several studies have proved that iron-chelate complexes improve the treatment effectiveness over equivalent non-chelated iron systems (BLOCK et al., 2004). In this case $\mathrm{Fe}(\mathrm{II})$ is consumed (turns into $\mathrm{Fe}(\mathrm{III})$ ) throughout persulfate activation, reducing its activity as oxidant. Therefore, to maintain activation of the persulfate system with iron over extended periods of time, iron must be present in solution. This may be accomplished by either acidification of the solution to around $\mathrm{pH} 3$, where $\mathrm{Fe}$ (III) becomes soluble, or by the use of organic-iron ligand complexes (or chelates) to maintain iron in solution at neutral pH (PETRI et al., 2011). Crimi \& Taylor (2007) investigated chelating agent-to-iron ratios, and found that a 1:5 ratio worked well for high iron concentration, while a higher dose of the chelating agent was needed if the iron concentration was low. Also, the photolysis of some Fe(III)-organic ligand complexes, namely Fe(III)-carboxylate complexes, is known as a self-depuration process of natural waters. Further in this work, the contribution of such process in the degradation of AMZcontaminated waters was investigated.

As an alternative activator, zero valent iron (ZVI), a solid source of iron, has been employed with promising results. The corrosion of this material will consist in a source of $\mathrm{Fe}^{2+}$ for PS activation, through three possible ways: (i) Direct release of $\mathrm{Fe}^{2+}$ by persulfate; (ii) Indirect release of $\mathrm{Fe}^{2+}$ in water with dissolved oxygen; and (iii) Indirect release of $\mathrm{Fe}^{2+}$ in water in the absence of oxygen (AL-SHAMSI; THOMSON, 2013).

$$
\begin{aligned}
& \mathrm{Fe}^{0}+\mathrm{S}_{2} \mathrm{O}_{8}{ }^{2-} \rightarrow \mathrm{Fe}^{2+}+2 \mathrm{SO}_{4}^{2-} \\
& 2 \mathrm{Fe}^{0}+\mathrm{O}_{2}+\mathrm{H}_{2} \mathrm{O} \rightarrow 2 \mathrm{Fe}^{2+}+4 \mathrm{OH}^{-} \\
& \mathrm{Fe}^{0}+2 \mathrm{H}_{2} \mathrm{O} \rightarrow \mathrm{Fe}^{2+}+2 \mathrm{OH}^{-}+\mathrm{H}_{2}
\end{aligned}
$$

Following its release from $\mathrm{ZVI}, \mathrm{Fe}^{2+}$ can activate persulfate to generate sulfate free radicals according to Eq. 9. Also, $\mathrm{Fe}^{2+}$ can be recycled by reaction between $\mathrm{Fe}^{3+}$ and the ZVI surface as follows (LIANG et al., 2008):

$$
2 \mathrm{Fe}^{3+}+\mathrm{Fe}^{0} \rightarrow 3 \mathrm{Fe}^{2+}
$$


Liang et al. (2008) reported trichloroethylene (TCE) degradation by ZVI-activated persulfate and concluded that persulfate promotes $\mathrm{Fe}^{2+}$ release from $\mathrm{Fe}^{0}$ more significantly than $\mathrm{Fe}^{0}$ alone. Therefore, these authors proved that the $\mathrm{Fe}^{0} / \mathrm{PS}$ system was an effective method for destroying TCE. However, due to the passivation of the ZVI surface along the process, the reaction rate might be halted after a while, which consists in a drawback of this process.

\section{iv) Activation by hydrogen peroxide}

During the PS activation with hydrogen peroxide, the $\mathrm{H}_{2} \mathrm{O}_{2}$ molecule decomposes exothermically once in contact with water (Eq. 14) and, therefore, indirectly induces heat PS activation. Also, when $\mathrm{pH}$ is increased to above the $\mathrm{pKa}$ of hydrogen peroxide, the deprotonated species, $\mathrm{HO}_{2}^{-}$(Eq. 15), may interact with $\mathrm{S}_{2} \mathrm{O}_{8}{ }^{2-}$ in accordance with (Eq. 8). However, hydrogen peroxide directly reacts with PS, resulting in simultaneous decompositions of both $\mathrm{H}_{2} \mathrm{O}_{2}$ and PS (Eq. 16) (LIANG; GUO; PAN, 2014):

$$
\begin{aligned}
& \mathrm{H}_{2} \mathrm{O}_{2} \rightarrow \mathrm{H}_{2} \mathrm{O}+0.5 \mathrm{O}_{2} \quad \Delta \mathrm{H}^{0}=-98.2 \mathrm{~kJ} \mathrm{~mol}^{-1} \\
& \mathrm{H}_{2} \mathrm{O}_{2} \rightleftarrows \mathrm{HO}_{2}^{-}+\mathrm{H}^{+} \quad \mathrm{pK}_{\mathrm{a}}=11.62 \\
& \mathrm{H}_{2} \mathrm{O}_{2}+\mathrm{S}_{2} \mathrm{O}_{8}{ }^{2-} \rightarrow 2 \mathrm{H}^{+}+2 \mathrm{SO}_{4}^{2-}+\mathrm{O}_{2}
\end{aligned}
$$

Cronk and Cartwright (2006) reported that hydrogen peroxide could support persulfate activation by raising subsurface temperatures. Using controlled $\mathrm{H}_{2} \mathrm{O}_{2}$ dosage to the subsurface, the authors observed the increase in subsurface temperatures to $60-80{ }^{\circ} \mathrm{C}$, achieving persulfate activation via Eq. 4.

\section{v) Activation with UV radiation}

The scission of persulfate $\mathrm{O}-\mathrm{O}$ bond to generate $\mathrm{SO}_{4}{ }^{-}$can be also mediated by UV irradiation, similarly to heat activation presented in Eq. 4. Photolysis efficiency strongly depends on the oxidant absorptivity. The majority of UV activated oxidation processes are performed with UVC lamps emitting mainly at $254 \mathrm{~nm}$. However, at this wavelength, persulfate has a very low molar absorption coefficient $\left(\varepsilon_{254 \mathrm{~nm}} \mathrm{~S}_{2} \mathrm{O}_{8}{ }^{2-}=20 \mathrm{~L} \mathrm{~mol}^{-1} \mathrm{~cm}^{-1}\right)$ (MARK et al., 1990), as well as its major competitive oxidant $\mathrm{H}_{2} \mathrm{O}_{2}\left(\varepsilon_{254 \mathrm{~nm}} \mathrm{H}_{2} \mathrm{O}_{2}=19.6 \mathrm{~L}\right.$ $\mathrm{mol}^{-1} \mathrm{~cm}^{-1}$ ) (GLAZE; KANG; CHAPIN, 1987). This means that, in order to generate sufficient radicals capable to degrade the target contaminants, even higher concentrations 
of the oxidant must be used. Notwithstanding, even with similar absorptivity $(\varepsilon)$ values at $254 \mathrm{~nm}$, an investigation developed by Raharinirina et al. (2009) revealed a better performance of $\mathrm{UV} / \mathrm{S}_{2} \mathrm{O}_{8}{ }^{2-}$ comparing to $\mathrm{UV} / \mathrm{H}_{2} \mathrm{O}_{2}$, based on the energy necessary to break the oxidant $\mathrm{O}-\mathrm{O}$ bond. Since this bond in persulfate is weaker than in hydrogen peroxide, less energy is needed and consequently sulfate radicals might be formed more readily than hydroxyl radicals. The study of ibuprofen (IBF) removal by $\mathrm{UV} / \mathrm{H}_{2} \mathrm{O}_{2}$ and $\mathrm{UV} / \mathrm{S}_{2} \mathrm{O}_{8}{ }^{2-}$ also revealed a better performance of the latter (KWON et al., 2015). Also, despite the low molar absorptivity of both oxidants above $280 \mathrm{~nm}$, sodium persulfate reveals higher values of $\varepsilon$ at longer wavelengths (BUCK; SINGHADEJA; ROGERS, 1954), enabling the application of UVA rays, the main type of UV radiation reaching the Earth's surface (300-400 $\mathrm{nm})$, for persulfate activation.

All of these activation methods for persulfate initiate powerful oxidation processes capable of degrading a wide range of organic contaminants. However, not all mechanisms are well understood, remaining gaps in the knowledge related to persulfate ISCO. This fact consisted in one of the main motivations behind the present work.

\section{OBJECTIVES}

The aim of this first chapter is to explore different oxidation processes, driven mainly by $\mathrm{SO}_{4}{ }^{-}$or ${ }^{\circ} \mathrm{OH}$, in terms of amicarbazone degradation effectiveness. For that, four investigations were performed, each one having its own objectives:

1) To study AMZ degradation kinetics promoted by UVA-activated persulfate in the presence of $\mathrm{H}_{2} \mathrm{O}_{2}, \mathrm{Fe}(\mathrm{II})$ or $\mathrm{Fe}(\mathrm{III})$-carboxylate complexes;

2) To understand the interaction between $\mathrm{pH}$ and $\mathrm{Fe}(\mathrm{III})$ :carboxylate ratio on AMZ degradation under UVA radiation, through a surface response model, in order to explore the contribution of these complexes to the self-depuration of natural waters;

3) To monitor AMZ sample toxicity resulting from some of the processes explored in the two previous studies, towards five microorganisms representative of different taxonomic levels; and

4) To study $A M Z$ degradation promoted by ZVI-activated persulfate and how ZVI source and size, PS and ZVI dosage, UVA radiation, dissolved oxygen and inorganic ions affect this process. 


\section{AMICARBAZONE DEGRADATION BY UVA-ACTIVATED PERSULFATE IN THE PRESENCE OF HYDROGEN PEROXYDE OR Fe ${ }^{2+}$}

In recent years, persulfate (PS)-driven oxidation has been extensively studied as an efficient remediation technique for in situ chemical oxidation of contaminated sites. Among other ways, PS can be activated by UV radiation, but most UV sources applied in PS activation studies are in the UVC range (ex $\sim 254 \mathrm{~nm})$, whilst the use of UVA, which is the UV radiation most incident on Earth's surface $(300-400 \mathrm{~nm})$, has received less attention. Successful applications of UVC-activated PS have been widely reported for the degradation of a large variety of persistent contaminants, such as drugs (GAO et al., 2012; KWON et al., 2015; TAN et al., 2013; ZHANG et al., 2014), dyes (SAIEN; SOLEYMANI; SUN, 2011; YANG et al., 2010), endocrine disruptors (OLMEZ-HANCI; ARSLAN-ALATON; GENC, 2014), pesticides (LUTZE et al., 2015), etc., while the use of UVA radiation for the same purpose is usually included in the use of solar irradiation for PS activation, which is reported in the literature to a lower extent. Notwithstanding, the latter has been receiving growing attention, having as an example of its successful application a research where the decontamination of domestic wastewater containing carbamazepine was accomplished via solar PS activation (AHMED; CHIRON, 2014); other examples of solar-driven PS activation are mentioned in the literature (SAHOO; MARBANIANG; SHARAN, 2016; SHUKLA et al., 2010). To the best of our knowledge, the literature regarding the combination of solely UVA radiation and PS is still scarce (AVETTA et al., 2015; SAHOO; MARBANIANG; SHARAN, 2016). With the aim of contributing to the knowledge in this field, in this study the degradation of amicarbazone (AMZ), driven by the UVA-activated PS in the absence or in the presence of other PS activators, such as $\mathrm{H}_{2} \mathrm{O}_{2}, \mathrm{Fe}(\mathrm{II}), \mathrm{Fe}(\mathrm{III})$ and $\mathrm{Fe}(\mathrm{III})$-complexes, was explored. Up to date, this is the first time that UVA-activated persulfate and the combination of this process with other PS activation processes is carried out for AMZ degradation. Even though solar radiation would lead to more realistic results in terms of environmental applicability of the studied processes, UVA lamps are cheaper and lead to similar results without requiring complex apparatus.

As stated in section 1.3, AMZ represents an interesting target-pollutant to degrade with these processes, not only because it can pose an environmental threat in the near future, but also because there are no records in the literature regarding its degradation via AOP, thus contributing to the novelty of this investigation. 


\subsection{Materials and Methods}

\subsubsection{Chemicals}

Technical (>95.4\% w/w) and analytical grade $(99.9 \%, \mathrm{w} / \mathrm{w})$ samples of amicarbazone were obtained from Arysta LifeScience Corp. and used with no further purification. All the aqueous solutions were prepared in deionized water $(18.2 \mathrm{M} \Omega \mathrm{cm})$ obtained from a Milli-Q Direct-Q system (Millipore). Dilute solutions of sodium hydroxide or sulfuric acid were used for $\mathrm{pH}$ adjustment. Fe(III)-carboxylates complexes were prepared by mixing the solutions of $\mathrm{Fe}_{2}\left(\mathrm{SO}_{4}\right)_{3} .5 \mathrm{H}_{2} \mathrm{O}$ with the corresponding carboxylate, in the dark and before adding any other compound to the solution. All the other chemicals were of analytical grade. Hydrogen peroxide, persulfate, iron and chelated iron were added just before the UVA irradiation was turned on.

\subsubsection{Photochemical experiments}

Photodegradation experiments were carried out in the experimental setup illustrated in Figure 5, which was equipped with four 15-W blacklight lamps (Sylvania F15W/350 BL T8) emitting UVA radiation in the range 315-400 $\mathrm{nm}$ and providing 23.3 $\mathrm{W} \mathrm{m}^{-2}$ in this wavelength range (see APPENDIX A). For experiments with controlled $\mathrm{pH}$, exactly $100 \mathrm{~mL}$ of an aqueous solution containing $10 \mathrm{mg} \mathrm{L}^{-1}\left(41.4 \mu \mathrm{mol} \mathrm{L}{ }^{-1}\right)$ of AMZ buffered solution ( $5 \mathrm{mmol} \mathrm{L}^{-1}$ phosphate buffer) was irradiated in a $2000-\mathrm{mL}$ quartz beaker $\left(\varnothing_{\text {beaker }}=12 \mathrm{~cm}\right.$; solution depth $\left.\approx 1 \mathrm{~cm}\right)$ with magnetic stirring. The solution is positioned at $27 \mathrm{~cm}$ from the lamps. For experiments with free $\mathrm{pH}$, the experimental procedure was the same but without phosphate buffer addition. The reaction temperature was kept at $20 \pm 4{ }^{\circ} \mathrm{C}$ using a cool water bath. At each sampling time, a $270-\mu \mathrm{L}$ sample was collected and mixed with $\mathrm{MeOH}$ (10\% final concentration) to stop the reaction (VELOSA; NASCIMENTO, 2017). 


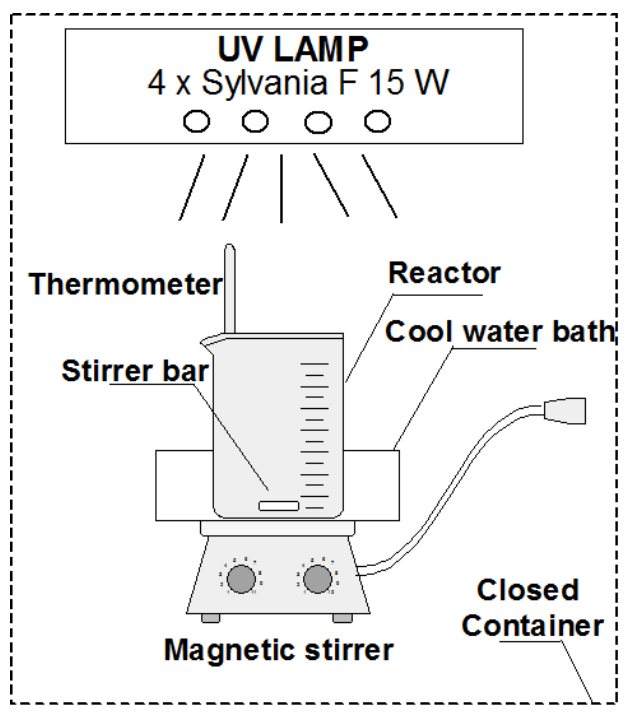

Figure 5. Experimental apparatus.

\subsubsection{Analytical methods}

Whenever appropriate, persulfate anion, $\mathrm{H}_{2} \mathrm{O}_{2}$ and $\mathrm{Fe}(\mathrm{II})$ concentrations were measured, according to the following spectrophotometric methods:

(i) The persulfate anion concentration was determined according to the method proposed by Liang et al. (2008): $0.1 \mathrm{~mL}$ of sample was added to a 40$\mathrm{mL}$ solution containing $4 \mathrm{~g}$ of $\mathrm{KI}$ and $0.2 \mathrm{~g}$ of $\mathrm{NaHCO}_{3}$. The yellow solution resulting from the reaction of persulfate and iodide in the presence of sodium bicarbonate was monitored at $400 \mathrm{~nm}$;

(ii) The hydrogen peroxide concentration was determined by the metavanadate method described in Nogueira et al. (2005): 1-mL sample was added to a 9-mL solution containing $0.062 \mathrm{~mol} \mathrm{~L}^{-1}$ of of metavanadate and $0.58 \mathrm{~mol} \mathrm{~L}^{-1}$ of $\mathrm{H}_{2} \mathrm{SO}_{4}$, in a $10-\mathrm{mL}$ volumetric flask and mixed. The change of color of the metavanadate ion $\left(\mathrm{VO}_{3}{ }^{-}\right)$, from yellow to red-orange, in the presence of $\mathrm{H}_{2} \mathrm{O}_{2}$, allowing its detection at $450 \mathrm{~nm}$. This method has a detection limit of $143 \mu \mathrm{mol} \mathrm{L}{ }^{-1}$ of $\mathrm{H}_{2} \mathrm{O}_{2}$.

(iii) The $\mathrm{Fe}$ (II) concentration was determined according to the o-phenantroline standard procedure (MORTATTI et al., 1982): $2 \mathrm{~mL}$ of the sample was added to $2 \mathrm{~mL}$ of 1,10 -phenanthroline $0.1 \%(\mathrm{w} / \mathrm{V})$ in a $15-\mathrm{mL}$ falcon tube and mixed, followed by the addition of $1 \mathrm{~mL}$ of sodium acetate solution $10 \%(\mathrm{w} / \mathrm{V})$. The absorbance was measured at the maximum absorption of the iron(II)phenantroline complex $\left(\lambda_{\max }=510 \mathrm{~nm}\right)$.

UV-vis absorption spectra were measured with a Varian Cary 50 UV-vis 
spectrophotometer using a 1-cm path-length Suprasil ${ }^{\circledR}$ quartz cuvette, in the range 190$820 \mathrm{~nm}$ and $1 \mathrm{~nm}$ intervals.

AMZ concentration during the degradation experiments was determined by HPLC-UV (Shimadzu, Series 20A) using a C18 column (ACE, $250 \times 4.6 \mathrm{~mm}$ ). The isocratic elution consisted of $50 \%$ methanol and $50 \%$ of aqueous solution containing $1 \%$ acetic acid, with a flow rate of $1.0 \mathrm{~mL} \mathrm{~min}^{-1}$. The injection volume was $50 \mu \mathrm{L}$ and the detection wavelength was $230 \mathrm{~nm}$. The limits of detection (LOD) and quantification (LOQ) were $1.03 \mu \mathrm{mol} \mathrm{L}{ }^{-1}$ and $3.09 \mu \mathrm{mol} \mathrm{L}^{-1}$, respectively (determined as described in APENDIX B).

All the experiments were performed at least in duplicate and the average of the experimental responses is reported hereinafter.

\subsection{Results and Discussion}

\subsubsection{Effect of initial persulfate and $A M Z$ concentrations}

In order to evaluate the effect of initial PS concentration on AMZ degradation, several PS concentrations were tested using a buffered $41.4 \mu \mathrm{mol} \mathrm{L}^{-1}\left(10 \mathrm{mg} \mathrm{L}^{-1}\right) \mathrm{AMZ}$ solution, at two different $\mathrm{pH}$ values (1.6 and 7). It is worth investigating an acidic condition because when PS is added to the reaction medium, the $\mathrm{pH}$ drops to near 2.6 $\left(\mathrm{AMZ} \mathrm{pKa}=2.58^{1}\right)$, so AMZ protonated groups can influence the degradation kinetics. AMZ degradation by persulfate-driven oxidation follows a pseudo first-order kinetics $\left(\mathrm{R}^{2}\right.$ $>0.96)$ and $k_{\mathrm{obs}}$ (observed pseudo first-order degradation rate constant) versus PS initial concentration is shown in Figure 6A, while the initial AMZ degradation rate $\left(r_{0}\right)$ as a function of initial $\mathrm{AMZ}$ concentration is shown in Figure 6B. AMZ degradation profiles for these experiments can be found in APENDIX C.

\footnotetext{
${ }^{1}$ chemicalize.org was used for predictions of molecular properties.
} 

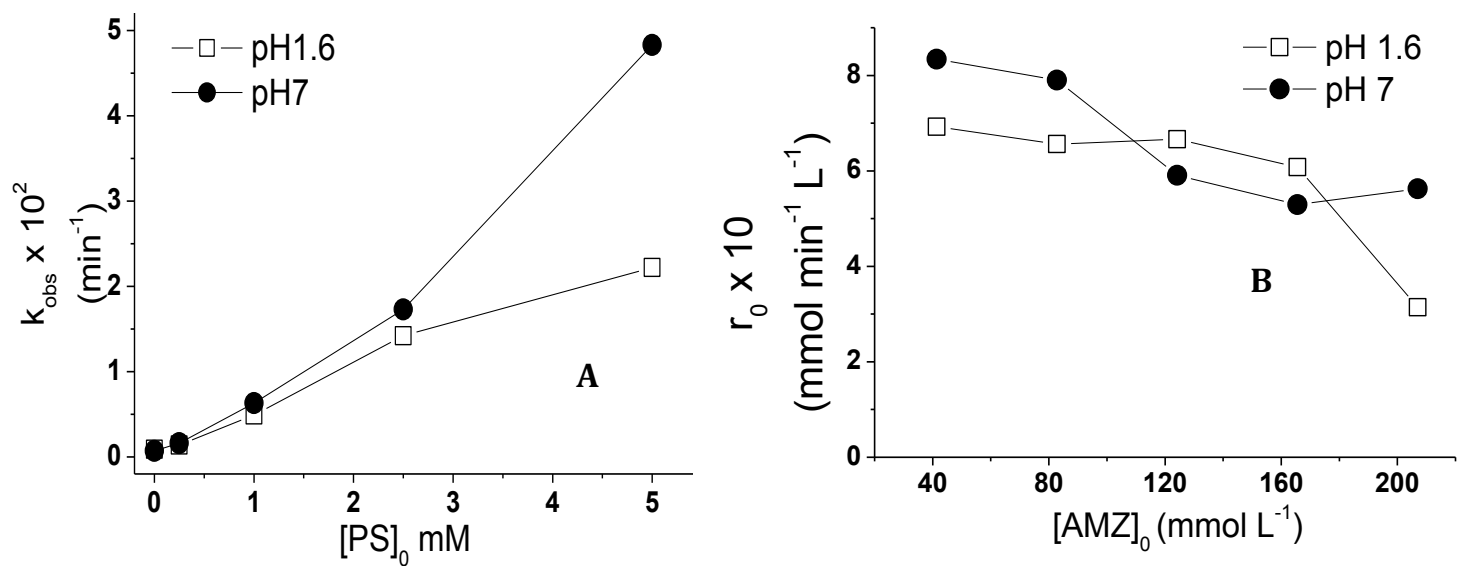

Figure 6. (A) Effect of PS on measured $k_{\mathrm{obs}}$;(B) Effect of AMZ initial concentrations on the initial AMZ degradation rate, $r_{0}$. Conditions: (A) $[\mathrm{AMZ}]_{0}=41.4 \mu \mathrm{mol} \mathrm{L}^{-1}, 0<[\mathrm{PS}]_{0}<5 \mathrm{mmol} \mathrm{L}^{-1}$; (B) $[\mathrm{PS}]_{0}=5 \mathrm{mmol} \mathrm{L}^{-1}$, $41.4<[\mathrm{AMZ}]_{0}<207.2 \mu \mathrm{mol} \mathrm{L}^{-1}$. Error bars are not included since they are smaller than the symbols.

Experimental results show that the initial persulfate concentration influenced $\mathrm{AMZ}$ degradation at both $\mathrm{pH}$ values tested, as expected. AMZ degradation increased for increasing PS dosage, since more reactive species are generated.

As aforementioned, the triazolinone group of AMZ molecules is protonated below $\mathrm{pH} 2.58$, hampering radical attack, since sulfate radicals act mainly by electron transfer (LUTZE, 2013). For PS concentrations below $2.5 \mathrm{mmol} \mathrm{L}^{-1}$, the rate of AMZ degradation is limited by the low amount of sulfate radicals generated, independently whether the target molecule is protonated or not. In that case, the values of $k_{\text {obs }}$ obtained at both $\mathrm{pH}$ values do not show significant differences. Conversely, for PS concentrations above 2.5 mmol $\mathrm{L}^{-1}$, sulfate radicals are not the limiting reactant and $\mathrm{pH}$ clearly affects the degradation kinetics, with higher $k_{\mathrm{obs}}$ values for $\mathrm{pH} 7$, at which the neutral form of the AMZ molecule dominates.

Figure 6B shows that the initial AMZ degradation rate $\left(r_{0}\right)$ values remain almost constant up to $165.5 \mathrm{mmol} \mathrm{L}^{-1}$ for $\mathrm{pH} 1.6$, decreasing above that [AMZ] $]_{0}$ value. This behavior can be explained by the fact that up to $165.5 \mathrm{mmol} \mathrm{L}^{-1}$ the amount of radicals might me enough to degrade an increasing amount of target-molecules at the same rate, becoming insufficient above that $[\mathrm{AMZ}]_{0}$. On the other hand, at $\mathrm{pH} 7, r_{0}$ values decrease by increasing the AMZ dosage, which is expected since sulfate radical generation is constant, depending on the UVA radiation intensity, and the quantity of target molecules is increased. This same behavior is not observed for both $\mathrm{pH}$ values since at $\mathrm{pH}$ 1.6 AMZ molecules are more difficult to degrade due to their protonated form, which explains the almost constant $r_{0}$ values until a certain amount of molecules. Several studies reported successful pollutant abatement with UVC-activated persulfate systems (KWON et al., 
2015; ZHANG et al., 2014), but very little is known about UVA-activated persulfate for the same purpose. Our results showed that even PS presenting a low molar absorptivity at this wavelength range (around $0.25 \mathrm{~mol}^{-1} \mathrm{~cm}^{-1}$ at $351 \mathrm{~nm}$ (LIN; LIANG; CHEN, 2011), UVA-activated persulfate degraded AMZ efficiently within a short irradiation period (less than 90 minutes for PS dosages above $5 \mathrm{mmol} \mathrm{L}^{-1}$ ).

\subsubsection{Effect of $\mathrm{H}_{2} \mathrm{O}_{2}$ addition to the PS/UVA system}

It is well known that $\mathrm{H}_{2} \mathrm{O}_{2}$ activates PS decomposition (LIANG; GUO; PAN, 2014), although the mechanism is still not well understood. Hence, the effect of $\mathrm{H}_{2} \mathrm{O}_{2}$ addition to the UVA/PS system was studied at fixed initial AMZ and PS concentrations. $[\mathrm{AMZ}]_{0}$ was $41.4 \mu \mathrm{mol} \mathrm{L}{ }^{-1}$, $[\mathrm{PS}]_{0}$ was 2.5 or $5 \mathrm{mmol} \mathrm{L}^{-1}$, and $\left[\mathrm{H}_{2} \mathrm{O}_{2}\right]_{0}$ was raised from 0 to $10 \mathrm{mmol} \mathrm{L}^{-1}$ (Table 6). Control experiments showed no notable consumption of $\mathrm{H}_{2} \mathrm{O}_{2}$ along the experiment (reaction time: 120 minutes).

The comparison of the PS/UVA systems at $\mathrm{pH} 7$ with and without $\mathrm{H}_{2} \mathrm{O}_{2}$ clearly shows that the presence of the second oxidant decelerates the reaction, thus suggesting that $\mathrm{H}_{2} \mathrm{O}_{2}$ is somehow scavenging $\mathrm{SO}_{4}{ }^{-}$(according to Eq. 17), generating a much weaker oxidant, the hydroperoxyl radical $\left(\mathrm{HO}_{2}{ }^{\circ}\right)\left(E^{0}=1.42 \mathrm{~V}\right.$ SHE (OPPENLÄNDER, 2003), superoxide radical at $\mathrm{pH}$ 7) (CHU; LAU; FUNG, 2006).

$\mathrm{SO}_{4}{ }^{--}+\mathrm{H}_{2} \mathrm{O}_{2} \rightarrow \mathrm{SO}_{4}{ }^{2-}+\mathrm{H}^{+}+\mathrm{HO}_{2}{ }^{\bullet}$

Under acidic $\mathrm{pH}\left(\mathrm{pH}\right.$ 1.6), the addition of $\mathrm{H}_{2} \mathrm{O}_{2}$ does not promote significant changes in PS/UVA $k_{\mathrm{obs}}$ values for both PS concentrations tested. The reaction given by Eq. 17 is unlikely to occur under extremely acidic conditions since hydrogen peroxide is protonated as the oxonium ion $\left(\mathrm{H}_{3} \mathrm{O}_{2}{ }^{+}\right)$(KWON et al., 1999), which is known to be very stable. This feature was also observed by other researchers when the Fenton reaction was performed at $\mathrm{pH}$ below 2 (KWON et al., 1999). In addition, the wavelength of the UV radiation used in these experiments (around $350 \mathrm{~nm}$ ) does not allow a significant conversion of this oxidant due to its low molar absorption coefficient $\left(\varepsilon_{350 \mathrm{~nm}}<0.1 \mathrm{~L} \mathrm{~mol}^{-}\right.$

${ }^{1} \mathrm{~cm}^{-1}$ ). Hence, due to its unavailability under acidic $\mathrm{pH}$, the addition of $\mathrm{H}_{2} \mathrm{O}_{2}$ does not significantly influence the PS/UVA system at $\mathrm{pH}$ 1.6. On the other hand, owing to the low probability to produce ${ }^{\circ} \mathrm{OH}$ radicals under UVA radiation, $\mathrm{H}_{2} \mathrm{O}_{2}$ molecules are able to hamper AMZ degradation at $\mathrm{pH} 7$.

Control experiments were performed to investigate the direct UVA-driven AMZ 
photolysis at both $\mathrm{pH}$ values studied, but only 10.3 and $4.8 \%$ removals after 120 minutes were observed at $\mathrm{pH} 1.6$ and 7, respectively. This was expected since AMZ does not absorb in the UVA range (see Figure D1 in APPENDIX D). To verify AMZ hydrolysis, the herbicide was kept in aqueous solution for $24 \mathrm{~h}$ and only $4 \%$ degradation was observed after that period, ensuring that this process was not responsible for AMZ removal in our experiments.

Also, control experiments were performed to check the effect of $\mathrm{H}_{2} \mathrm{O}_{2}$ under UVA radiation without PS and a variation of 1.6 and 2.8 times on $k_{\mathrm{obs}}$ for AMZ degradation at $\mathrm{pH} 1.6$ and 7, respectively, in comparison to that observed on UVA-photolysis, was observed.

Table 6. Values of $k_{\text {obs }}$ for the PS/ UVA system for different $\mathrm{H}_{2} \mathrm{O}_{2}$ initial concentrations.

\begin{tabular}{|c|c|c|c|}
\hline \multicolumn{4}{|c|}{$[\mathrm{PS}]_{0}=2.5 \mathrm{mmol} \mathrm{L}^{-1}$} \\
\hline \multicolumn{2}{|c|}{$\mathrm{pH} 1.6$} & \multicolumn{2}{|c|}{$\mathrm{pH} 7$} \\
\hline$\left[\mathrm{H}_{2} \mathrm{O}_{2}\right] \mathrm{mmol} \mathrm{L}^{-1}$ & $\begin{array}{c}k_{\text {obs }} \times 10^{3} \\
\left(\min ^{-1}\right)\end{array}$ & {$\left[\mathrm{H}_{2} \mathrm{O}_{2}\right] \mathrm{mmol} \mathrm{L}^{-1}$} & $\begin{array}{c}k_{\text {obs }} \times 10^{3} \\
\left(\min ^{-1}\right)\end{array}$ \\
\hline 0 & $13.7 \pm 0.7$ & 0 & $17.1 \pm 0.6$ \\
\hline 2.5 & $11.1 \pm 2.3$ & 2.5 & $7.9 \pm 1.3$ \\
\hline 5 & $15.3 \pm 2.9$ & 5 & $8.1 \pm 0.5$ \\
\hline 10 & $12.4 \pm 1.2$ & 10 & $14.2 \pm 1.9$ \\
\hline \multicolumn{4}{|c|}{$[\mathrm{PS}]_{0}=5 \mathrm{mmol} \mathrm{L}^{-1}$} \\
\hline \multicolumn{2}{|c|}{$\mathrm{pH} 1.6$} & \multicolumn{2}{|c|}{$\mathrm{pH} 7$} \\
\hline$\left[\mathrm{H}_{2} \mathrm{O}_{2}\right] \mathrm{mmol} \mathrm{L}^{-1}$ & $\begin{array}{c}k_{\mathrm{obs}} \times 10^{3} \\
\left(\min ^{-1}\right)\end{array}$ & {$\left[\mathrm{H}_{2} \mathrm{O}_{2}\right] \mathrm{mmol} \mathrm{L}^{-1}$} & $\begin{array}{c}k_{\mathrm{obs}} \times 10^{3} \\
\left(\min ^{-1}\right)\end{array}$ \\
\hline 0 & $21.2 \pm 0.4$ & 0 & $44.2 \pm 2.6$ \\
\hline 2.5 & $22.7 \pm 3.0$ & 2.5 & $17.0 \pm 1.1$ \\
\hline 5 & $21.4 \pm 2.7$ & 5 & $16.2 \pm 4.0$ \\
\hline 10 & $29.1 \pm 0.6$ & 10 & $15.4 \pm 1.5$ \\
\hline
\end{tabular}

\subsubsection{Effect of $\mathrm{Fe}^{2+}$ addition on the PS/UVA system}

Certain transition metals are known to stimulate the production of radicals when combined with persulfate (RAO et al., 2014). Ferrous Iron - Fe (II) - has been the most widely used due to its low environmental toxicity (Eq.9). Here, the AMZ degradation by the $\mathrm{Fe}(\mathrm{II}) / \mathrm{PS}$ process was studied and the results are presented in Figure 7. No notable consumption of PS was observed during these experiments. In order to evaluate the influence of each component in AMZ degradation, control experiments were carried out and revealed that neither sole PS nor sole Fe(II) are able to degrade AMZ in the absence 
of light, during the reaction period (120 min). However, when these two components are mixed together, they promote two-stage degradation kinetics, characterized by fast initial decay followed by a slower stage. This happens because of the high production of sulfate radicals at the moment of $\mathrm{Fe}(\mathrm{II})$ and persulfate mixture, leading to an instantaneous AMZ abatement (RAO et al., 2014). After complete ferrous ion consumption, only ferric iron (which is not able to catalyze persulfate break) remains in the solution and then the degradation is slower.

Conversely, when the reaction occurs in the presence of UVA radiation, this activation effect seems to remain and much faster AMZ degradation is observed. An attempt to relate this result to a Fe (II) - Fe (III) cycling, promoted by UVA radiation was made by measuring ferrous iron along the reaction time and the results point to a constant concentration of $20 \mu \mathrm{mol} \mathrm{L}-1$ along time. This indicates that, if ferrous ion is generated, it is continuously consumed by persulfate activation. It is worth noting that the $\mathrm{Fe}(\mathrm{II}) / \mathrm{PS} / \mathrm{UVA}$ system can be considered a photo-Fenton like process, since it combines persulfate (PS) as an oxidant, ferrous iron (Fe(II)) as a catalyst and a light source, as already mentioned by other authors (AHMED; CHIRON, 2014).

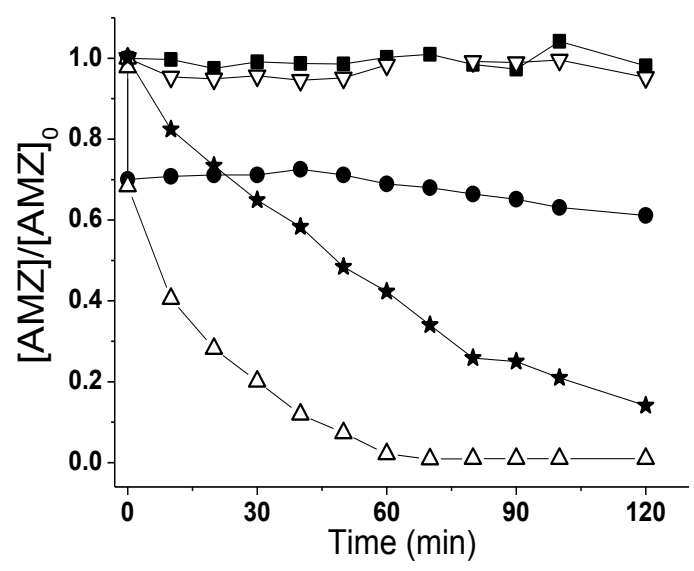

Figure 7. Effect of Fe(II) addition on AMZ degradation driven by PS/UVA at free pH. (ם) Sole Fe(II), ( $\nabla$ )

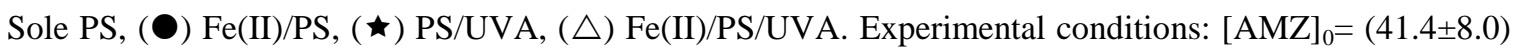
$\mu \mathrm{mol} \mathrm{L}{ }^{-1},[\mathrm{Fe}(\mathrm{II})]_{0}=0.134 \mathrm{mmol} \mathrm{L}^{-1},[\mathrm{PS}]_{0}=2.5 \mathrm{mmol} \mathrm{L}^{-1}$. Error bars are not included since they are smaller than the symbols.

A previous work, in which a solid source of Fe(II) (magnetite) was irradiated with UVA, also revealed the effective persulfate activation due to $\mathrm{Fe}^{\mathrm{III}}-\mathrm{Fe}^{\mathrm{II}}$ cycling (AVETTA et al., 2015).

If the degradation is carried out with initial $\mathrm{Fe}$ (III) instead of $\mathrm{Fe}(\mathrm{II})$ at $\mathrm{pH} 3$ (Figure 8), the reaction is a little slower but still shows a much better performance than without iron, proving that a synergic process involving PS oxidation and $\mathrm{Fe}(\mathrm{III})$ 
photolysis (KWON et al., 2015).

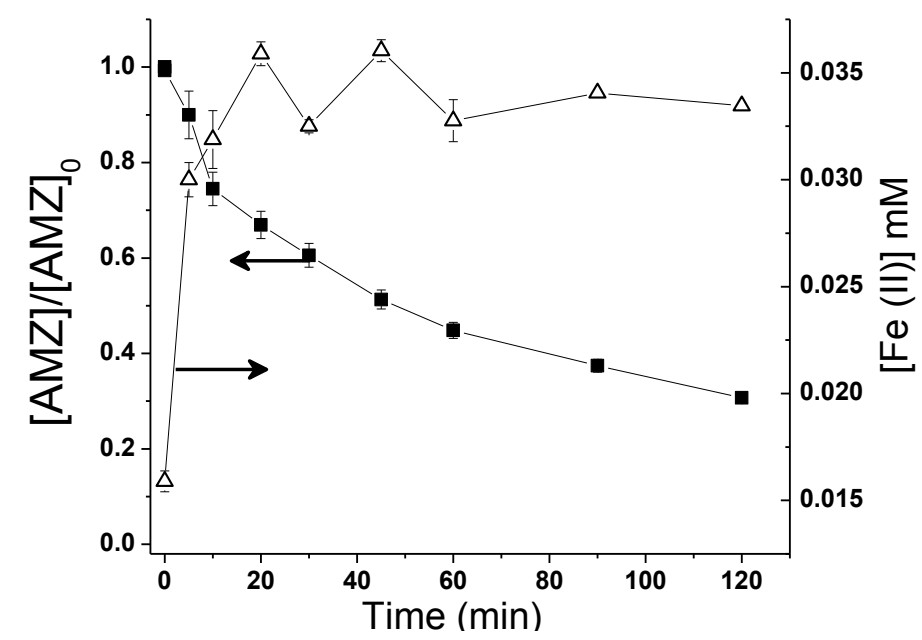

Figure 8. AMZ (- - -, left side) degradation by Fe(III)/UVA system $\left(k_{\mathrm{obs}}=0.04 \pm 4.8 \times 10^{-4} \mathrm{~min}^{-1}\right)$ and $[\mathrm{Fe}(\mathrm{II})]\left(-\triangle-\right.$, right side) measurement during the reaction. Experimental conditions: $[\mathrm{AMZ}]_{0}=(41.4 \pm 8.0)$ $\mu \mathrm{mol} \mathrm{L}{ }^{-1},[\mathrm{Fe}(\mathrm{III})]_{0}=0.134 \mathrm{mmol} \mathrm{L}^{-1}$, free $\mathrm{pH}$.

An attempt to perform the reaction under controlled $\mathrm{pH}$ with phosphate buffer showed the inhibition of AMZ degradation (data not shown), probably caused by the complexation of $\mathrm{Fe}(\mathrm{III})$ by phosphate, leading to a photo-inactive complex, as reported elsewhere (WELCH; DAVIS; AUST, 2002).

In our experimental conditions, the initial $\mathrm{pH}$ is around 5 and drops to 3 when persulfate and $\mathrm{Fe}$ (II) are added. In the absence of any other ligand, $\mathrm{Fe}$ (III) species form a complex with water and/ or hydroxide anions giving aqua complexes such as $\left[\mathrm{Fe}^{\mathrm{III}} \mathrm{OH}\left(\mathrm{H}_{2} \mathrm{O}\right)_{5}\right]^{2+}$, which is the predominant species at $\mathrm{pH} 3$. This complex undergoes a LMCT (ligand to metal charge transfer) under sunlight irradiation, which is followed by the inner-sphere photoinductive electron transfer, producing the $\mathrm{Fe}(\mathrm{II})$ aqua complex and one ${ }^{\circ} \mathrm{OH}$ radical (Eq. 18) (CIEŚLA et al., 2004). Although our irradiation experiments used UVA lamps instead of sunlight, the Fe(III) photoactive hydroxo complex reveals great absorption within the UVA lamps emission band (see Figure D2 in APPENDIX D), meaning that these are also capable of promoting the same LMCT effect.

$$
\left[\mathrm{Fe}^{\mathrm{III}} \mathrm{OH}\left(\mathrm{H}_{2} \mathrm{O}\right)_{5}\right]^{2+}+\mathrm{H}_{2} \mathrm{O} \stackrel{\text { hv(LMCT) }}{\longrightarrow}\left[\mathrm{Fe}^{\mathrm{II}}\left(\mathrm{H}_{2} \mathrm{O}\right)_{6}\right]^{2+}+\cdot \mathrm{OH}
$$

This is a well-known mechanism that occurs in natural waterbodies which contributes to its auto depuration (CIEŚLA et al., 2004).

\subsubsection{Effect of chelated-Fe(III) on PS/UVA system}


In the previous section, we observed that $\mathrm{Fe}(\mathrm{III})$ species can form an aqua complex able to produce ${ }^{\circ} \mathrm{OH}$ radicals upon UVA irradiation. However, in the presence of other chelating agents, such as carboxylates, there could be another photochemical mechanism for generating ${ }^{\circ} \mathrm{OH}$ radicals (WANG et al., 2006). In this case, the reaction begins with an electron transfer from the complexed organic ligand (LL) to Fe(III) in the excited state of the Fe(III)-LL complex (POZDNYAKOV et al., 2012). This results in the generation of $\mathrm{Fe}(\mathrm{II})$ and a positive organic radical $\left(\mathrm{LL}^{\circ+}\right)$ which can reduce molecular $\mathrm{O}_{2}$ to $\mathrm{O}_{2}{ }^{--}$leading to hydrogen peroxide production and then to the hydroxyl radical, under acidic conditions (Eqs. 19-22) (JOSEPH; VARGHESE; ARAVINDAKUMAR, 2001; KWON et al., 2015; WANG et al., 2006).

$$
\begin{aligned}
& {\left[\mathrm{Fe}^{\mathrm{III}}-\mathrm{LL}\right] \stackrel{\mathrm{hv}}{\rightarrow}[\mathrm{Fe}(\mathrm{II})-\mathrm{LL}]^{*} \rightarrow \mathrm{Fe}(\mathrm{II})+\mathrm{LL}^{\bullet+}} \\
& \mathrm{LL}^{\bullet+}+\mathrm{O}_{2} \rightarrow \mathrm{O}_{2}^{\bullet-}+\mathrm{LL}^{2+} \\
& 2 \mathrm{H}^{+}+2 \mathrm{O}_{2}^{\bullet-} \rightarrow \mathrm{H}_{2} \mathrm{O}_{2}+\mathrm{O}_{2} \\
& \mathrm{H}_{2} \mathrm{O}_{2}+\mathrm{Fe}(\mathrm{II}) \rightarrow \mathrm{Fe}(\mathrm{III})+\mathrm{HO}^{\bullet}+\mathrm{OH}^{-}
\end{aligned}
$$

Some previous studies reported that in a system in which the medium was forced to remain neutral (buffered), the activation of persulfate with chelated-iron was better than an equivalent non-chelated iron system (PETRI et al., 2011, OPPENLÄNDER, 2003). In fact, at neutral $\mathrm{pH}, \mathrm{Fe}(\mathrm{III})$ tends to precipitate as solid ferric hydroxide $\left[\mathrm{Fe}(\mathrm{OH})_{3}\right]$, thus reducing or even eliminating its activity toward oxidants. Hence, the use of carboxylates as iron ligands (or chelates) can extend the $\mathrm{pH}$ range of photolysis and increase the quantum yield of ferrous iron generation.

In the case of PS activation by chelated iron, the ferrous iron is the species usually used, since the only ferric iron complex currently known to be effective in the activation of PS in neutral pH is the Fe(III)-EDTA (LIANG; LIANG; CHEN, 2009). On the other hand, several organic complexes have been studied to increase the degradation of organic compounds by photolysis and, in this case, the iron species used is the ferric one.

For verifying the effect of different Fe(III)-complexes on PS activation, some naturally occurring ligands, oxalate $\left(\mathrm{C}_{2} \mathrm{O}_{4}{ }^{2-}\right)$, citrate $\left(\mathrm{C}_{6} \mathrm{H}_{5} \mathrm{O}_{7}{ }^{3-}\right)$ and tartrate $\left(\mathrm{C}_{4} \mathrm{H}_{4} \mathrm{O}_{6}{ }^{2-}\right)$ were selected for testing. The ratio of Fe(III):carboxylates was set according to the mode they are commonly found in nature, i.e. 1:3 Fe(III):oxalate (KOCAR; INSKEEP, 2003), 1:2 Fe(III):citrate (KÖNIGSBERGER et al., 2000), 1:1 Fe(III):tartrate (FENG; DING; 
XIE, 2012) and not necessarily represent the most photoactive compounds. Although we did not set a constant $\mathrm{pH}$ value, it varied around 3 in all the experiments with chelated iron. The absorbption spectra of AMZ solutions in the presence of $\mathrm{Fe}(\mathrm{II}), \mathrm{Fe}(\mathrm{III})$ and each one of the $\mathrm{Fe}(\mathrm{III})$-carboxylates complexes indicate that the pesticide does not form complexes with these species, at least, under our experimental conditions (see Figure D3 in APPENDIX D). Also, overlapping these Fe(III)-carboxylates absorbption spectra with the UVA lamps emission spectrum is possible to observe that they absorb in the UVA range, enabling the reactions described by Eqs.19-22 (see Figure D4 in APPENDIX D).

Figure 9 shows the effect of Fe(III) complexes in AMZ oxidation by UVAactivated persulfate. The photo generated Fe(II) concentration throughout the reaction was also measured. These results showed that chelated-Fe(III) promoted a faster AMZ degradation than non-chelated-Fe(III), which can be explained by the contribution of the photolysis process promoted by these complexes. This generates reactive species which help to degrade AMZ, and cycles the iron species leading to $\mathrm{Fe}(\mathrm{II})$, which activates the persulfate. Figure 9B allows observing that citrate promoted a threefold increase in Fe(II) concentration along the reaction time. Citrate also promotes the production of $\mathrm{Fe}(\mathrm{II})$ from $\mathrm{Fe}(\mathrm{III})$ even in the dark (data not shown), which consists in an additional contribution of this ligand to enhancing the degradation rate.

As verified, among the tested ligands, tartrate showed the ability to activate persulfate even in the dark, promoting around $40 \%$ of AMZ degradation at time zero, just after PS addition. This indicates that after lamps were turned on, the photoactive Fe(III)tartrate complex was not necessarily the same as in the beginning, since a molecular ratio of $1 \mathrm{Fe}(\mathrm{III}): 1$ tartrate was used and some ligand molecules may have been destroyed.

Even though organic ligands are well known to compete with the target pollutant for oxidizing species, this effect was not observed under the experimental conditions investigated. In fact, the AMZ degradation profiles were very similar for oxalate, citrate, and tartrate, although the Fe(III)-citrate system seems to perform slightly better.

Control experiments based on the photolysis of these same complexes in the same conditions showed that the Fe(III)-oxalate complex had the best performance in AMZ degradation but the reaction stalled after 20 minutes, probably caused by oxalate depletion. Han et al. (2015) observed that, for lower ligand:iron molecular ratios, Fe(II)citrate complex was a better PS activator than oxalate and tartrate for degrading aniline. By using the same ligand:iron molecular ratio used in the present paper, however, the best 
performance presented by the ligands was tartrate $>$ oxalate $>$ citrate, with a very close pseudo-first order $k_{\mathrm{obs}}$ for tartrate and oxalate (HAN et al., 2015).
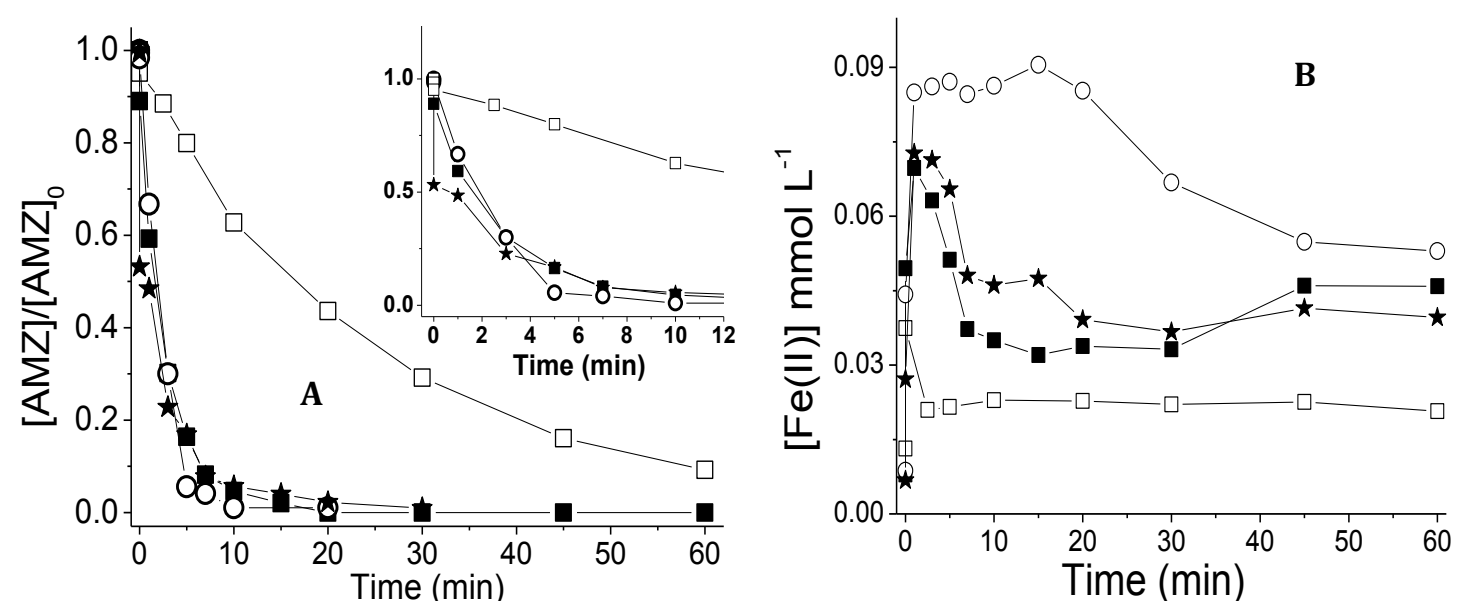

Figure 9. Effect of different $\mathrm{Fe}(\mathrm{III})$ complexes: $\mathrm{Fe}(\mathrm{III})$-aqua complex (- $\square$-); $\mathrm{Fe}(\mathrm{III})$-oxalate (-口-); $\mathrm{Fe}(\mathrm{III})$ citrate (-O-); Fe(III)-tartrate (- $\star$-) on (A) AMZ degradation promoted by the PS/UVA system and (B) $\mathrm{Fe}(\mathrm{II})$ concentration along the reaction time. Experimental conditions: $[\mathrm{AMZ}]_{0}=(41.4 \pm 8.0) \mu \mathrm{mol} \mathrm{L}^{-1},[\mathrm{PS}]_{0}$ $=2.5 \mathrm{mmol} \mathrm{L}^{-1},[\mathrm{Fe}(\mathrm{III})]=0.1 \mathrm{mmol} \mathrm{L}^{-1}, \mathrm{Fe}(\mathrm{III}):$ ligand ratio: $1 \mathrm{Fe}(\mathrm{III}): 3$ oxalato, $1 \mathrm{Fe}(\mathrm{III}): 2$ citrate, and 1 $\mathrm{Fe}(\mathrm{III}): 1$ tartrate, free $\mathrm{pH}$. Error bars are not included since they are smaller than the symbols.

\subsection{Partial conclusions}

The previous results allowed concluding that the UVA/PS system is able to efficiently degrade AMZ-contaminated water, with degradation rates following pseudo first-order kinetics. The values of $k_{\mathrm{obs}}$ increased with increased PS concentrations and decreased with AMZ concentration, although a better performance has been achieved under neutral $\mathrm{pH}$. The degradation efficiency of AMZ by UVA/PS system was significantly decreased when $\mathrm{H}_{2} \mathrm{O}_{2}$ was added at $\mathrm{pH}$ 7, but remained almost unchanged at $\mathrm{pH}$ 1.6, showing no advantage in adding this second oxidant. In the presence of $\mathrm{Fe}(\mathrm{II})$, at free $\mathrm{pH}$, the $\mathrm{AMZ}$ degradation rate obtained for the UVA/PS system increased about 4.5 times due to the synergistic effect of PS activation by UVA, by $\mathrm{Fe}(\mathrm{II})$ and by $\mathrm{Fe}$ (III) photolysis, which recycles iron and generates extra hydroxyl radicals. The addition of chelated-Fe(III) to the UVA/PS system hugely increased the AMZ degradation rate with a very close performance for tested iron complexes. 


\section{THE ROLE OF FE(III)-CARBOXYLATES IN AMZ PHOTODEGRADATION: A RESPONSE SURFACE STUDY BASED ON A DOEHLERT EXPERIMENTAL DESIGN}

Iron is the most common transition metal found in natural waters, playing an important role in water self-depuration processes (CIEŚLA et al., 2004). Usually found in natural waters chelated by organic ligands, the thermodynamically stable form of iron (Fe(III)) is rapidly photo-reduced to $\mathrm{Fe}(\mathrm{II})$, which is accompanied by the oxidation of the organic ligand and other organic compounds, especially those constituting natural organic matter (CIEŚLA et al., 2004; ZUO; HOIGNE, 1994). In surface waters, the presence of oxygen allows $\mathrm{Fe}(\mathrm{II})$ to oxidize back to $\mathrm{Fe}(\mathrm{III})$ and the iron cycling is reestablished. Hence, this photoredox cycle of $\mathrm{Fe}$ (III) complexes is very important to the environmental self-depuration mechanisms since it also contributes to the photodegradation of especially persistent organic pollutants, such as benzotriazoles (LIU et al., 2013) and pesticides (POZDNYAKOV et al., 2016). However, depending on the natural organic ligand found in water or in the structure of the organic pollutant being considered, stable nonphotoactive iron complexes can be formed and, therefore, the efficiency of the degradation/depuration process can be reduced (MANENTI et al., 2015; SILVA et al., 2010). For example, ethylenediaminetetraacetic acid (EDTA) is known to hamper the photoredox cycle of iron due to the formation of extremely stable complexes with $\mathrm{Fe}$ (III) (SUN; PIGNATELLO, 1993); similarly, the herbicide tebuthioron was proved to form a strong complex with $\mathrm{Fe}(\mathrm{III})$, which hampers its photoreduction to $\mathrm{Fe}(\mathrm{II})$ (SILVA et al., 2010). In contrast, some natural-occurring organic ligands, such as carboxylates, form strong soluble $\mathrm{Fe}(\mathrm{III})$ complexes which are photo-reactive under sunlight (BALMER; SULZBERGER, 1999; SERAGHNI et al., 2012; WANG et al., 2006).

UVA radiation of such complexes can produce both $\mathrm{Fe}(\mathrm{II})$, by ligand-to-metal charge transfer (LMCT) (Eq. 19) reactions, and $\mathrm{H}_{2} \mathrm{O}_{2}$, reducing $\mathrm{O}_{2}$ by the photo-excited carboxylate (Eqs. 20 and 21) (BALMER; SULZBERGER, 1999; SERAGHNI et al., 2012). As a consequence, the Fenton reaction occurs when $\mathrm{Fe}(\mathrm{II})$ and $\mathrm{H}_{2} \mathrm{O}_{2}$ are combined, resulting in ${ }^{\circ} \mathrm{OH}$ radicals, which play a crucial role in the degradation of aqueous pollutants (Eq. 22).

Common carboxylates present in the environment, such as oxalate, citrate and tartrate are known to form strong complexes with Fe(III). These complexes have been 
successfully applied to enhance the photolysis of pesticides in water, such as atrazine (BALMER; SULZBERGER, 1999; OU et al., 2008) and 2,4-D (POZDNYAKOV et al., 2016). Nevertheless, a review of the current literature indicates few studies devoted to the systematic investigation of the role played by $\mathrm{Fe}(\mathrm{III})$-carboxylates on pesticides degradation.

This investigation aims to shed some light on the role of Fe(III)-carboxylate complexes photolysis on the degradation of an emerging pesticide, amicarbazone (AMZ), under UVA irradiation through a careful experimental design approach.

In order to cover different environmental scenarios, in this study the effects of factors such as $\mathrm{pH}$ and type/concentration of the organic ligand were explored, since they are known to strongly affect the rate of the reaction described by Eq. 19. With the goal of finding out the most efficient combination of ferric iron complex and $\mathrm{pH}$ upon $\mathrm{AMZ}$ degradation, a Doehlert experimental design was used due to its advantages, such as the need of fewer experiments, higher efficiency and capacity to move through the experimental domain (FERREIRA et al., 2004, 2007). Furthermore, additional experiments were performed in a real water matrix, with the purpose of assessing the effect of other natural water constituents, like dissolved organic matter and inorganic species.

\subsection{Materials and Methods}

\subsubsection{Chemicals}

Technical (> 95.4\% w/w) and analytical grade $(99.9 \%$, w/w) samples of amicarbazone were obtained from Arysta LifeScience Corp. and used with no further purification. All the aqueous solutions were prepared in deionized water $(18.2 \mathrm{M} \Omega \mathrm{cm})$, obtained from a Milli-Q Direct-Q system (Millipore), except when the influence of real water constituents was explored. For that, a sample from a sewage treatment plant effluent (STP Barueri, São Paulo, Brazil) was used, with the following composition: $\mathrm{Ag}^{+}$ (0.021 mg L $\left.\mathrm{mg}^{-1}\right), \mathrm{Al}^{3+}\left(0.178 \mathrm{mg} \mathrm{L}^{-1}\right), \mathrm{Ca}^{2+}\left(15.7 \mathrm{mg} \mathrm{L}^{-1}\right)$, total Co $\left(0.021 \mathrm{mg} \mathrm{L}^{-1}\right)$, total $\mathrm{Cr}$ (0.012 $\left.\mathrm{mg} \mathrm{L}^{-1}\right)$, total $\mathrm{Cu}\left(0.109 \mathrm{mg} \mathrm{L}^{-1}\right)$, total Fe $\left(0.111 \mathrm{mg} \mathrm{L}^{-1}\right), \mathrm{Mg}^{2+}\left(3.01 \mathrm{mg} \mathrm{L}^{-1}\right)$, total $\operatorname{Mn}\left(0.113 \mathrm{mg} \mathrm{L}^{-1}\right), \mathrm{Na}^{+}\left(68.8 \mathrm{mg} \mathrm{L}^{-1}\right), \mathrm{Ni}^{2+}\left(0.023 \mathrm{mg} \mathrm{L}^{-1}\right), \mathrm{Cl}^{-}\left(70.6 \mathrm{mg} \mathrm{L}^{-1}\right), \mathrm{NO}_{3}{ }^{-}(9.27$ $\left.\mathrm{mg} \mathrm{L}^{-1}\right), \mathrm{SO}_{4}{ }^{2-}\left(44.8 \mathrm{mg} \mathrm{L}^{-1}\right), \mathrm{pH}=7.8$, Total Organic Carbon $(\mathrm{TOC})=20 \mathrm{mg} \mathrm{L}^{-1}$, Inorganic Carbon (IC): $20.7 \mathrm{mg} \mathrm{L}^{-1}$. The analytical methods used for characterizing the 
real water sample are detailed in Section 4.1.3. All the other chemicals were of analytical grade. Fe(III)-carboxylates complexes were prepared by mixing the solutions of $\mathrm{Fe}_{2}\left(\mathrm{SO}_{4}\right)_{3} .5 \mathrm{H}_{2} \mathrm{O}$ with the corresponding carboxylate, in the dark and before adding any other compound to the solution.

\subsubsection{Photo oxidation experiments}

The same experimental apparatus and photo-oxidation experimental procedure described in section 3.1 was used in this study, excepting the $\mathrm{pH}$ control procedure along the experiment, since here an automated $\mathrm{pH}$ control system was used for such purpose (see APPENDIX E).

\subsubsection{Analytical methods}

$\mathrm{Fe}(\mathrm{II})$ was measured colorimetrically as reported by Mortatti et al. (1982) and described in section 4.1.2.

$\mathrm{H}_{2} \mathrm{O}_{2}$ concentrations were measured according to the method developed by Bader et al. (1988) using N,N-diethyl-p-phenylenediamine (DPD), but with the modifications suggested by Balmer and Sulzberger (1999) to minimize the interference of $\mathrm{Fe}(\mathrm{II})$ and $\mathrm{Fe}(\mathrm{III}): 0.4 \mathrm{~mL}$ of phosphate buffer solution (pH 6, $0.5 \mathrm{~mol} \mathrm{~L}^{-1}$ ) and $0.1 \mathrm{~mL}$ of bipyridine solution $\left(0.01 \mathrm{~mol} \mathrm{~L}^{-1}\right)$ were premixed in a $10 \mathrm{~mL}$ beaker; $2 \mathrm{~mL}$ of the sample, $0.02 \mathrm{~mL}$ of EDTA solution ( $\left.0.01 \mathrm{~mol} \mathrm{~L}^{-1} \mathrm{NaEDTA}\right)$, and $0.03 \mathrm{~mL}$ of DPD (1\% in $0.1 \mathrm{~mol}$ $\mathrm{L}^{-1} \mathrm{H}_{2} \mathrm{SO}_{4}$ ) were then added, followed by $0.03 \mathrm{~mL}$ of POD (horseradish peroxidase, type VI, specific activity of 250-300 units $\mathrm{mg}^{-1}$ ) reagent (about $0.5 \mathrm{~g} \mathrm{~mL}^{-1}$ ). Bipyridine was used to complex Fe(II), while EDTA was used to complex Fe(III). The absorbance at 551 $\mathrm{nm}$ was measured. This method of $\mathrm{H}_{2} \mathrm{O}_{2}$ quantification was preferred to the other mentioned in the previous section due its higher sensibility (detection limit of $10 \mathrm{nmol} \mathrm{L}^{-}$ $1)$.

Absorption spectra were acquired with a Varian Cary 50 UV-vis spectrophotometer using $1 \mathrm{~cm}$ path-length Suprasil ${ }^{\circledR}$ quartz cuvette.

TOC and IC analyses of the real water sample were carried out in a TOC-L analyzer (Shimadzu).

For the real water sample, the metal cations content was determined by ICP-OES, using the model 710 equipment from Agilent Technologies; anions concentrations were 
determined by ion chromatography, using a Metrohm equipment with a conductivity detector (850 Professional IC 1) and a Metrosep A Supp 5-150/4 column.

The photo-generation of ${ }^{\circ} \mathrm{OH}$ radicals by the photolysis of $\mathrm{Fe}(\mathrm{III})$-complexes was measured using benzene as a probe, according to methods detailed elsewhere (WANG et al., 2006; ZHANG et al., 2006). However, due to the high volatilization of benzene, these experiments were performed in a closed $100-\mathrm{mL}$ volumetric flask instead of a beaker, in order to avoid benzene losses due to evaporation during irradiation. Before doing so, we made sure that AMZ degradation was the same, whether it was performed in the beaker or in the volumetric flask, by testing the same conditions in both systems. The formation of phenol from benzene was monitored at $270 \mathrm{~nm}$ using HPLC-UV (Shimadzu, Series 20A). The eluent was $40 \%$ methanol and $60 \% \mathrm{H}_{2} \mathrm{O}$ with $1 \%$ of acetic acid, at a flow rate of $1 \mathrm{~mL} \mathrm{m^{-1 }}$ using a $\mathrm{C} 18$ column (Phenomenex, $250 \times 4.6 \mathrm{~mm}$ ) and an injection volume of $20 \mu \mathrm{L}$. A concentration of $7 \mathrm{mmol} \mathrm{L}^{-1}$ benzene was used (much higher than Fe(III) and carboxylates) in order to ensure it captures all hydroxyl radicals generated in the reaction. According to previous studies the $\cdot \mathrm{OH}$-mediated oxidation of benzene forms phenol with nearly $100 \%$ yield; moreover, benzene is very unreactive towards ${ }^{1} \mathrm{O}_{2}\left({ }^{1} \Delta_{\mathrm{g}}\right)$. Hence, the concentration of photochemically formed hydroxyl radicals was determined as being the same as phenol (Zhan et al. 2006).

AMZ concentration during the degradation experiments was followed by HPLCUV (Shimadzu, Series 20A) using the same column and methodology previously described (see section 4.1.3).

\subsubsection{Doehlert Uniform Array Design for two variables and response surface model}

A Doehlert uniform array design was used to find the optimum condition for AMZ degradation promoted by $\mathrm{Fe}(\mathrm{III})$-carboxylate complexes. The number of experiments required $(\mathrm{N})$ is given by $N=n^{2}+n+c$, where $n$ is the number of variables and $c$ is the number of central points. We decided to fix $c$ at 3 ; therefore, for two factors (pH and iron:ligand ratio), the total number of points of the Doehlert matrix was nine. Replicates of the central point were performed to validate the model by means of an estimate of the experimental variance. The response variable was the observed pseudo first-order degradation constant for the first 20 minutes of reaction $\left(k_{\mathrm{obs}}, \mathrm{min}^{-1}\right)$, since 
longer reaction times can lead to deviations from the first-order kinetics due to the presence of degradation intermediates.

The Fe(III):ligand ratio was studied at five levels (1:1, 1:2, 1:3, 1:4, and 1:5) and $\mathrm{pH}$ at three levels $(3.5,5.7$, and 8$)$; to change the $\mathrm{Fe}(\mathrm{III})$ :ligand ratio, the $\mathrm{Fe}(\mathrm{III})$ initial concentration was set at $0.1 \mathrm{mmol} \mathrm{L}^{-1}$, whilst the ligand concentration varied from 0.1 to $0.5 \mathrm{mmol} \mathrm{L}^{-1}$. Multiple regression analysis based on the least square method was performed using Statgraphics ${ }^{\circledR}$ Centurion XVI software. The response surface model for $k_{\text {obs }}$ is a second-order polynomial equation with six coefficients (Eq. 23), where $X_{1}$ and $X_{2}$ are the coded variables studied (Fe(III):ligand ratio and $\mathrm{pH}$, respectively).

$k_{o b s}=b_{0}+b_{1} X_{1}+b_{2} X_{2}+b_{11} X_{1}^{2}+b_{22} X_{2}^{2}+b_{12} X_{1} X_{2}$

Table 7 shows the Doehlert design followed to perform the experiments.

Table 7. Doehlert design for two variables with $c=3$.

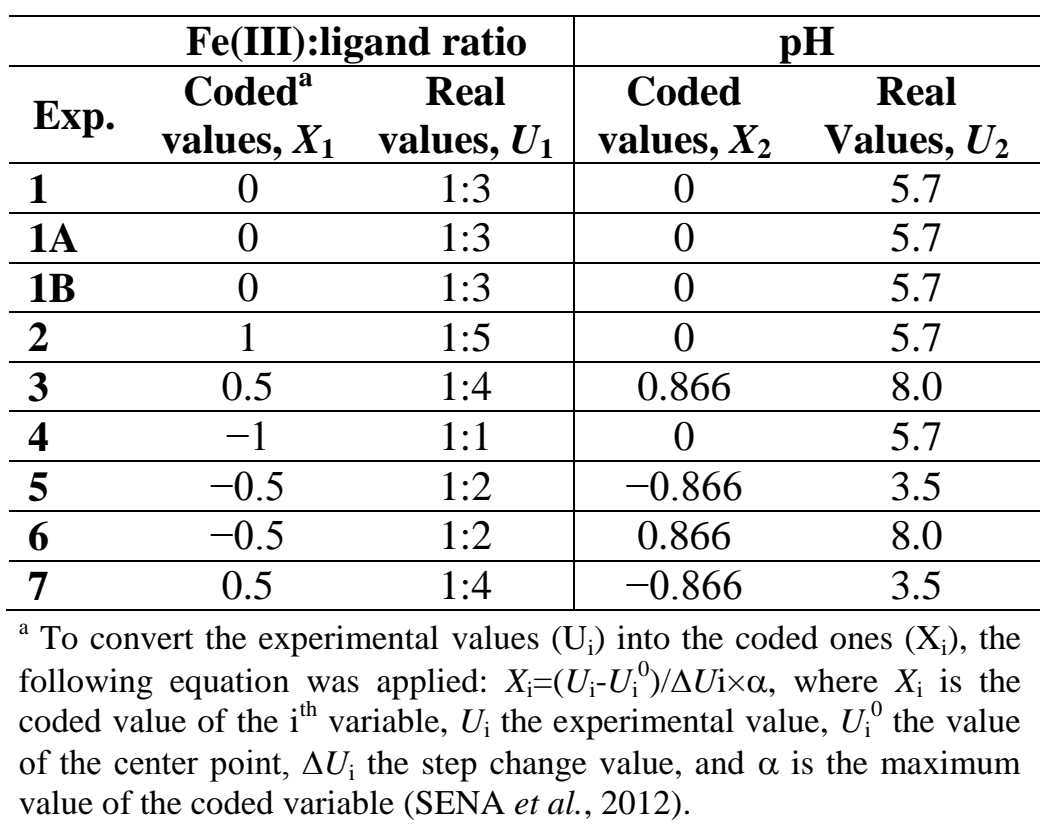

\subsection{Results and Discussion}

\subsubsection{AMZ degradation promoted by the photooxidation of $\mathrm{Fe}$ (III)-oxalate complex}

For evaluating the effect of both $\mathrm{pH}$ and $\mathrm{Fe}(\mathrm{III})$ :oxalate ratio on AMZ degradation, nine experiments were performed following the Doehlert design (Table 6), fixing $[\mathrm{AMZ}]_{0}=41.4 \mu \mathrm{mol} \mathrm{L}{ }^{-1}$ and $[\mathrm{Fe}(\mathrm{III})]_{0}=0.1 \mathrm{mmol} \mathrm{L}^{-1}$. The results are shown in Table 8. The corresponding response surface model is given by Eq. 24. The determination coefficient, $R^{2}$, was equal to 0.994 and the effects of $\mathrm{pH}, \mathrm{pH}^{2}, \mathrm{Fe}(\mathrm{III})$ :oxalate and 
$\mathrm{Fe}(\mathrm{III})$ :oxalate $\times \mathrm{pH}$ on the observed degradation rate $\left(k_{\mathrm{obs}}, \mathrm{min}^{-1}\right)$ were the most important, as shown by the ANOVA and the Pareto chart $(F$-test with $\mathrm{P}<0.005)$ (APPENDIX F, Table F1 and Figure F1, respectively).

$k_{o b s}=45.2+147.0 X_{1}-13.6 X_{2}-47.5 X_{1}^{2}+0.9 X_{2}^{2}-13.6 X_{1} X_{2}$

For all the $\mathrm{pH}$ values tested, the increase in oxalate content led to an increase in $k_{\text {obs. }}$. Additional experiments with oxalate concentration 10-fold higher than iron concentration at $\mathrm{pH} 3.5$ reinforced this tendency, for which a $k_{\mathrm{obs}}$ of $(103.3 \pm 19.7) \times 10^{-3}$ $\min ^{-1}$ was obtained up to 20 minutes of reaction. For this condition, the model shown in Eq. 24 does not give an accurate $k_{\mathrm{obs}}$ prediction, since this experiment is outside the design domain. However, more realistic models can be obtained by moving the original design into a more promising region, which, in this case, is into higher values of Fe(III):oxalate. According to Ferreira et al. (2007) this is an interesting property of Doehlert designs, because they allow the experimental domain to be displaced without losing some of the runs already performed. Given that, the original design was displaced, maintaining experiments $1,2,3$ and 7 , in such a way that only three more experiments were needed: i) $\mathrm{Fe}$ (III):oxalate ratio of $1: 10$ at $\mathrm{pH} 3.5$; ii) $\mathrm{Fe}(\mathrm{III})$ :oxalate ratio of 1:11 at pH 5.7 and iii) Fe(III):oxalate ratio of 1:10 at pH 8 (Figure 10, Table 9).

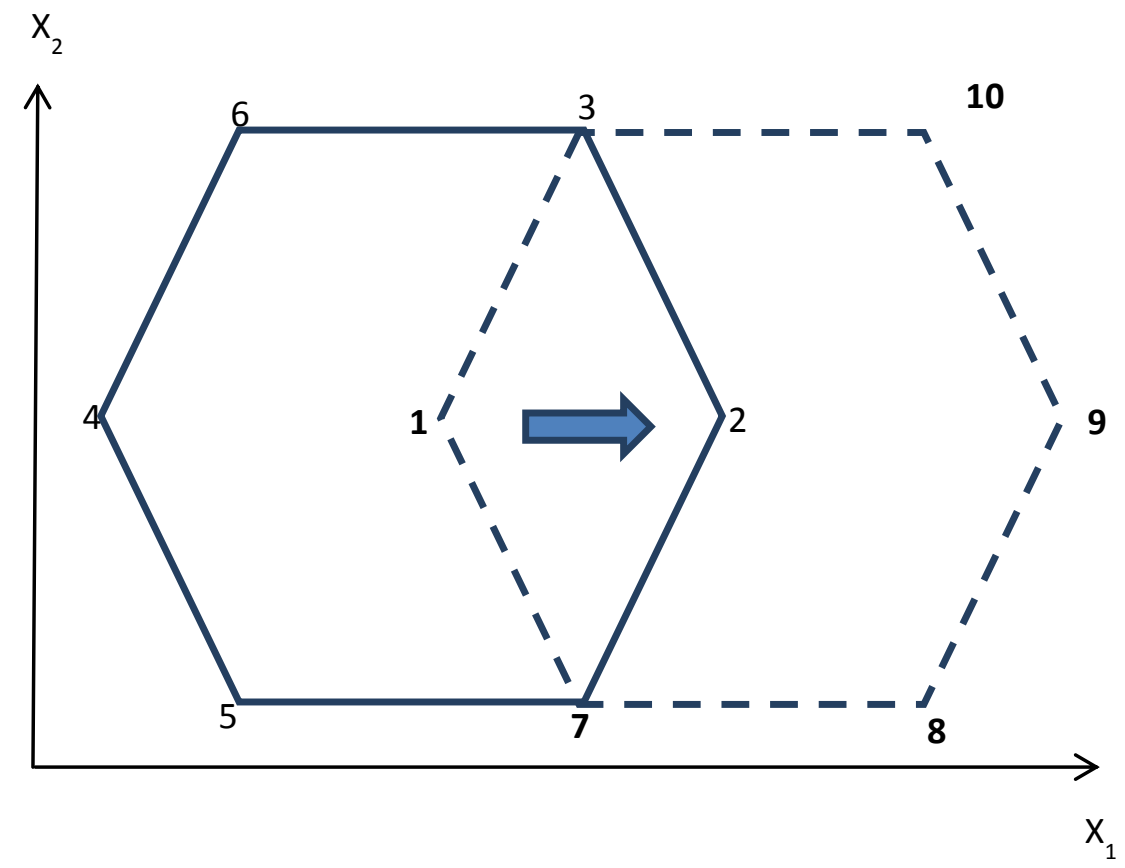

Figure 10. Displacement of the original two-factor Doehlert design for the $\mathrm{Fe}^{\mathrm{III}}$-oxalate system. 
Table 8. Doehlert design matrix for two factors and experimental values of $k_{\text {obs }}$ for the Fe(III)-oxalate system in the presence of $[\mathrm{AMZ}]_{0}=41.4 \mu \mathrm{mol} \mathrm{L}-1$ and $[\mathrm{Fe}(\mathrm{III})]_{0}=0.1 \mathrm{mmol} \mathrm{L}^{-1}$.

\begin{tabular}{cccc}
\hline Exp. & $\begin{array}{c}\text { Fe(III):oxalate } \\
\text { ratio }\end{array}$ & pH & $\begin{array}{c}\boldsymbol{k}_{\mathbf{o b s}}{ }^{\mathbf{a}} \times \mathbf{1 0}^{\mathbf{3}} \\
\left(\mathbf{m i n}^{-\mathbf{1}}\right)\end{array}$ \\
\hline $\mathbf{1}$ & $1: 3$ & 5.7 & 13.0 \\
\hline $\mathbf{1 A}$ & $1: 3$ & 5.7 & 14.0 \\
\hline $\mathbf{1 B}$ & $1: 3$ & 5.7 & 15.0 \\
\hline $\mathbf{2}$ & $1: 5$ & 5.7 & 21.2 \\
\hline $\mathbf{3}$ & $1: 4$ & 8.0 & 1.7 \\
\hline $\mathbf{4}$ & $1: 1$ & 5.7 & 3.0 \\
\hline $\mathbf{5}$ & $1: 2$ & 3.5 & 27.8 \\
\hline $\mathbf{6}$ & $1: 2$ & 8.0 & 1.3 \\
\hline $\mathbf{7}$ & $1: 4$ & 3.5 & 40.0 \\
\hline
\end{tabular}

${ }^{a}$ Calculated for the first 20 minutes of reaction.

Table 9. Additional experiments for the Fe(III):oxalate system.

\begin{tabular}{cccccc}
\hline Exp. & $\boldsymbol{X}_{\mathbf{1}}{ }^{\mathbf{a}}$ & $\boldsymbol{X}_{\mathbf{2}}{ }^{\mathbf{a}}$ & $\begin{array}{c}\mathbf{F e}(\mathrm{III}): \mathbf{0 x a l a t e} \\
\text { ratio }\end{array}$ & $\mathbf{p H}^{\mathbf{b}}$ & $\begin{array}{c}\boldsymbol{k}_{\mathbf{o b s}}{ }^{\mathbf{c}} \times \mathbf{1 0}^{\mathbf{3}} \\
\left.\mathbf{m i n}^{\mathbf{- 1}}\right)\end{array}$ \\
\hline 8 & 3.5 & -0.866 & $1: 10$ & 3.5 & 103.3 \\
\hline 9 & 4 & 0 & $1: 11$ & 5.7 & 81.6 \\
\hline 10 & 3.5 & 0.866 & $1: 10$ & 8 & 2.2 \\
\hline
\end{tabular}

${ }^{\mathrm{a}}$ Coded values; ${ }^{\mathrm{b}}$ Real values; ${ }^{\mathrm{c}}$ Calculated for the first 20 minutes of reaction.

This displacement turned the fitting by the response surface model (Eq. 25) slightly poorer $\left(R^{2}=0.982\right)$ and $\mathrm{pH}$ and $\mathrm{Fe}(\mathrm{III})$ : oxalate $\times \mathrm{pH}$ was then the only significant factor $(\mathrm{P}<0.005)$ (APPENDIX F, Table F2 and Figure F2).

However, predictions based on this model are now much more coherent with our experimental results and previous studies regarding irradiated $\mathrm{Fe}(\mathrm{III})$-oxalate systems (BALMER; SULZBERGER, 1999; ZHOU; WU; DENG, 2004). Figure 11A shows the response surface and Figure 11B the corresponding contour plot.

$k_{o b s}=3.6+91.9 X_{1}+5.4 X_{2}+80.8 X_{1}^{2}-0.4 X_{2}^{2}-23.4 X_{1} X_{2}$ 
A
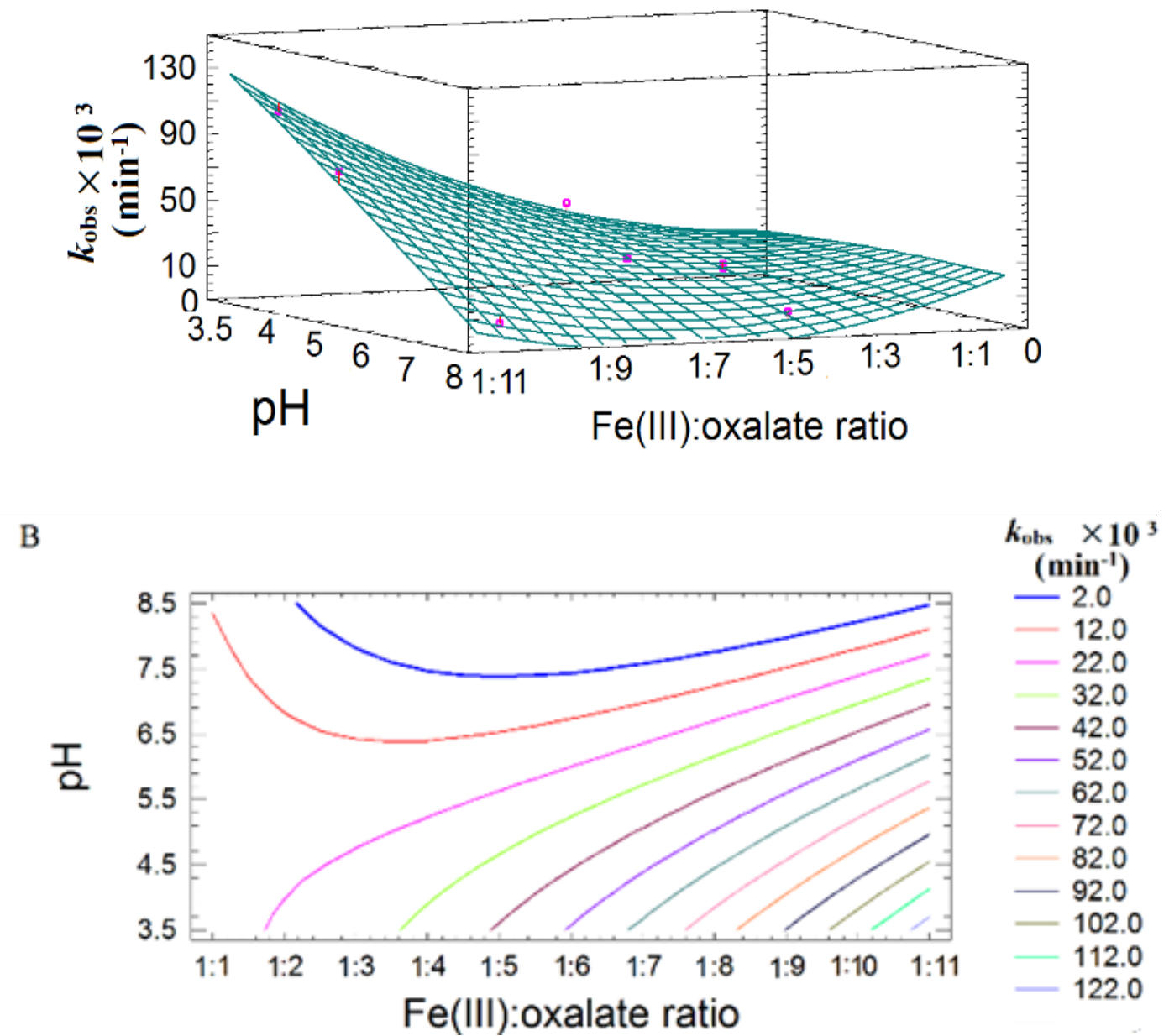

Figure 11. (A) Response surface including the experimental points (pink dots) and (B) contour plot for $k_{\mathrm{obs}}$, varying the $\mathrm{Fe}(\mathrm{III})$ :oxalate ratio from 0 to $1: 11$ and $\mathrm{pH}$ from 3.5 to 8.5 .

In the present study, the highest $k_{\mathrm{obs}}$ was obtained for the lowest $\mathrm{pH}(3.5)$ and the highest oxalate concentration $\left(1 \mathrm{mmol} \mathrm{L}^{-1}\right)$. Balmer and Sulzberger (1999) observed a similar behavior for atrazine degradation promoted by the photolysis of $\mathrm{Fe}$ (III)-oxalate complexes, where the degradation rate increased with increasing oxalate concentration for $\mathrm{pH}$ around 3.

These results can be correlated with the distribution of $\mathrm{Fe}(\mathrm{III})$-oxalate complex species as a function of $\mathrm{pH}$ and metal: ligand ratio under tested conditions; this species distribution can be predicted by the use of the Visual MINTEQ program (ver. 3.1) (APPENDIX F, Figure F3).

Under our experimental conditions, there are three main Fe(III)-oxalate complex species $-\mathrm{Fe}(\text { oxalate })^{+}, \mathrm{Fe}($ oxalate $){ }_{2}{ }^{-}$and $\mathrm{Fe}($ oxalate $) 3^{3-}-$ in which the iron molar fraction (\%) distribution varies according to the $\mathrm{pH}$ and ligand concentration. When the oxalate concentration is low ( $\mathrm{Fe}(\mathrm{III})$ :oxalate ratio $=1: 1)$, as the $\mathrm{pH}$ of the system increases, the 
number of oxalate molecules in the Fe(III)-complex also increases; hence, raising the $\mathrm{pH}$ makes the $\mathrm{Fe}$ (oxalate) ${ }_{3}{ }^{3-}$ molar fraction higher at $\mathrm{pH} 6.5$, consequently decreasing the molar fraction of the other carboxylate complex species. This iron-complex distribution can explain the relative high $\mathrm{AMZ}$ degradation rate observed at neutral $\mathrm{pH}$ like those usually found in surface waters. This can be attributed to the photo-reactivity of $\mathrm{Fe}$ (oxalate) $3^{3-}$ species, whose concentration is the highest compared to that of the other iron-complex species (BALMER; SULZBERGER, 1999). This result is very important from an application point of view because it reveals that AMZ degradation in natural waters and under neutral $\mathrm{pH}$ is expected to be possible if there is oxalate present, even at very low concentrations.

As shown in Figure 11, by fixing the $\mathrm{Fe}(\mathrm{III})$ :oxalate ratio and increasing $\mathrm{pH}$ up to 8 resulted in lower $k_{\text {obs }}$ values, since the concentration of the $\mathrm{Fe}(\mathrm{OH})_{2}{ }^{+}$species (low photoactivity) (BENKELBERG; WARNECK, 1995) becomes important and iron begins to precipitate, especially at low $\mathrm{Fe}(\mathrm{III})$ :oxalate ratios and at $\mathrm{pH}$ above 8 . However, if the $\mathrm{Fe}(\mathrm{III})$ :oxalate ratio varies from 1:1 to $1: 10$ in neutral to basic medium, Figure 11B allows verifying that the reaction rate is kept the same as for lower oxalate concentrations at $\mathrm{pH}$ 3.5. Therefore, an increase in oxalate content can compensate the effect of $\mathrm{pH}$ and rapid AMZ degradation can be expected in natural waters (neutral $\mathrm{pH}$ ) if high $\mathrm{Fe}(\mathrm{III})$ :oxalate ratios present.

\subsubsection{AMZ degradation promoted by the photo-oxidation of Fe(III)-citrate complex}

Citrate is a natural carboxylate ligand that forms strong complexes with $\mathrm{Fe}(\mathrm{III})$ and has already been studied for 3-methylphenol degradation by photolysis (SERAGHNI et al., 2012). Here the AMZ degradation driven by the photolysis of $\mathrm{Fe}(\mathrm{III})$-citrate complexes was investigated using a Doehlert design (Table 10), fixing $[\mathrm{AMZ}]_{0}=41.4$ $\mu \mathrm{mol} \mathrm{L} \mathrm{L}^{-1}$ and $[\mathrm{Fe}(\mathrm{III})]_{0}=0.1 \mathrm{mmol} \mathrm{L}^{-1}$ in the $\mathrm{pH}$ range $3.5-8$. The fitted response surface model is given by Eq. 26. The determination coefficient, $R^{2}$, was equal to 0.934 and only the effect of $\mathrm{pH}$ on the observed degradation rate $\left(k_{\mathrm{obs}}, \min ^{-1}\right)$ was considered significant, as shown by the ANOVA and the Pareto chart $(F$-test with $\mathrm{P}<0.005)$ (APPENDIX G, Table F3 and Figure F4, respectively). 
Table 10. Doehlert design matrix for two factors and experimental values of $k_{\mathrm{obs}}$ for the Fe(III)-citrate system in the presence of $[\mathrm{AMZ}]_{0}=41.4 \mu \mathrm{mol} \mathrm{L}-1$ and $[\mathrm{Fe}(\mathrm{III})]_{0}=0.1 \mathrm{mmol} \mathrm{L}^{-1}$.

\begin{tabular}{cccc}
\hline Exp. & $\begin{array}{c}\text { Fe(III):citrate } \\
\text { ratio }\end{array}$ & $\mathbf{p H}$ & $\begin{array}{c}\boldsymbol{k}_{\text {obs }} \times \mathbf{1 0}^{\mathbf{3}} \\
\left(\mathbf{m i n}^{-\mathbf{1}}\right)^{\mathbf{a}}\end{array}$ \\
\hline $\mathbf{1}$ & $1: 3$ & 5.7 & 7.5 \\
$\mathbf{1 A}$ & $1: 3$ & 5.7 & 10 \\
$\mathbf{1 B}$ & $1: 3$ & 5.7 & 6.4 \\
$\mathbf{2}$ & $1: 5$ & 5.7 & 6.1 \\
$\mathbf{3}$ & $1: 4$ & 8.0 & 3.5 \\
$\mathbf{4}$ & $1: 1$ & 5.7 & 3.1 \\
$\mathbf{5}$ & $1: 2$ & 3.5 & 10.7 \\
$\mathbf{6}$ & $1: 2$ & 8.0 & 2.3 \\
$\mathbf{7}$ & $1: 4$ & 3.5 & 12.5 \\
\hline
\end{tabular}

${ }^{\text {a }}$ Calculated for the first 20 minutes of reaction.

$k_{o b s}=9.5+61.8 X_{1}-2.2 X_{2}-84.1 X_{1}^{2}+0.04 X_{2}^{2}+0.7 X_{1} X_{2}$

The $k_{\text {obs }}$ values in Table 10 show that the highest response value was achieved for the lowest $\mathrm{pH}$ (3.5) and $\mathrm{Fe}(\mathrm{III})$ :citrate ratio equal to 1:4. However, the couple of experiments performed at $\mathrm{pH} 3.5$ did not yield much different $k_{\mathrm{obs}}$ values, therefore suggesting that increasing the citrate content in the $\mathrm{Fe}(\mathrm{III})$ :citrate ratio only promotes slight improvements. To verify this hypothesis, additional experiments with citrate concentration 10-fold higher than iron concentration at $\mathrm{pH} 3.5$ were performed, resulting in a lower $k_{\mathrm{obs}}$ (average of $5.4 \times 10^{-3} \mathrm{~min}^{-1}$ ), thus suggesting that an excessive amount of [citrate $]_{0}$ hampers the reaction. It is worth noting that this result is not predicted by Eq. 26 because the conditions are outside the design domain. Speciation of $\mathrm{Fe}(\mathrm{III})$ predicted by Visual MINTEQ confirms that above an $\mathrm{Fe}(\mathrm{III})$ :citrate ratio of $1: 4$, for $\mathrm{pH}$ in the range 3.5-6.0, the content of photoactive Fe(III)-citrate complex (Fe-citrate (aq)) does not change significantly (APPENDIX F, Figure F5), increasing mainly the amount of free citrate species, which are known to scavenge ${ }^{\circ}$ OH (SERAGHNI et al., 2012). Given that, the response surface and contour plots (Figure 12) provide acceptable estimations based on experimental results and set the 1:4 Fe(III)-citrate ratio as the best one for AMZ degradation, independently of the $\mathrm{pH}$. Although the photolysis of $\mathrm{Fe}$ (III)-citrate has not 
been deeply explored in the literature, in contrast with that of Fe(III)-oxalate, some papers reported the ferric citrate complex as a source of free radicals to degrade toxic pollutants under UVA radiation (KOLÁŘ et al., 2011; SERAGHNI et al., 2012). However, these authors evaluated the role of an increase in the Fe(III)-citrate concentration on pollutants degradation rather than a change in the $\mathrm{Fe}(\mathrm{III})$ :citrate ratio, making a direct comparison with our results not possible. On the other hand, Zhang et al. (2006) quantified the photo production of hydroxyl radicals by the Fe(III)-citrate and observed that the increase in citrate concentration up to $1: 12$ in the $\mathrm{Fe}(\mathrm{III})$ :citrate ratio led to a considerable increase in the ${ }^{\circ} \mathrm{OH}$ production.

A
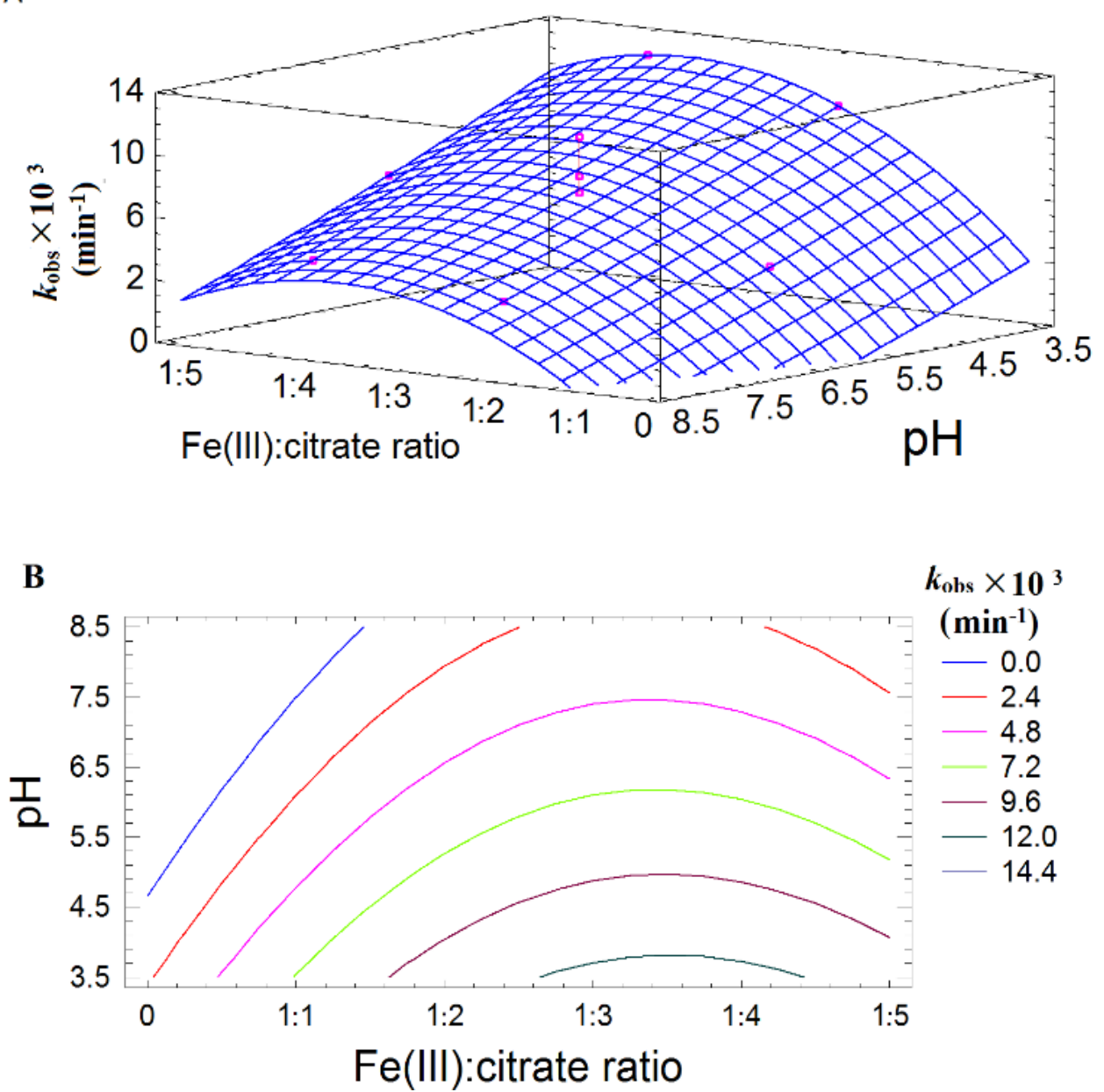

Figure 12. (A) Response surface including the experimental points (pink dots) and (B) contour plot for $k_{\mathrm{obs}}$, varying the $\mathrm{Fe}(\mathrm{III})$ :citrate ratio from 0 to $1: 5$ and $\mathrm{pH}$ from 3.5 to 8.5 .

As observed in Figure12, increasing pH results in decreasing $k_{\mathrm{obs}}$. Kolář et al. (2011) and Seraghni et al. (2012) also observed a similar behavior, yet using a 1:1 $\mathrm{Fe}(\mathrm{III})$ :citrate ratio. These authors explained that such behavior is based on the formation of less photoactive species and the precipitation of non-chelated $\mathrm{Fe}(\mathrm{III})$ near neutral $\mathrm{pH}$, which compromises the iron photocatalytic cycle and, therefore, the production of 
radicals. Very low values of $k_{\mathrm{obs}}$ were obtained at $\mathrm{pH} 8$, which can be explained by the speciation of Fe(III)-citrate under our experimental conditions. As shown in Figure F5 (see APPENDIX F), a less photoactive species starts appearing (namely $\mathrm{Fe}(\mathrm{OH})_{2}{ }^{+}$) above $\mathrm{pH} \mathrm{7,} \mathrm{for} \mathrm{all} \mathrm{the} \mathrm{Fe}(\mathrm{III})$ :citrate ratios explored, thus explaining the worse performance obtained under alkaline conditions. On the other hand, increasing the concentration of citrate up to a $\mathrm{Fe}(\mathrm{III})$ :citrate ratio of $1: 3.5$ promotes the total complexation of $\mathrm{Fe}(\mathrm{III})$ species and allows the photolysis process to proceed even under neutral conditions. Faust and Zepp (1993), studying the photochemistry of aqueous $\mathrm{Fe}(\mathrm{III})$ :carboxylates complexes, have also reported that the quantum yield of $\mathrm{Fe}(\mathrm{II})$ formation at $436 \mathrm{~nm}$ decreased when the $\mathrm{pH}$ was raised from 4 to 6 , keeping the Fe(III):citrate ratio constant. Although we have used a different excitation wavelength, the same cause might explain the lower degradation rates in less acidic conditions.

It is worth mentioning that Kolár et al. (2011) and Seraghni et al. (2012) observed two-step degradation kinetics, a fast one in the beginning of the reaction, promoted by the citrate complex, and then a slower one, promoted by the photolysis of the $\mathrm{Fe}(\mathrm{III})$ aquacomplex, for a wide range of $\mathrm{pH}$ values. In contrast, for most experiments, our results indicated single-step degradation profiles over time, which are expected to result from ferric citrate photolysis, since in the majority of the conditions tested, citrate was kept in excess compared to iron concentration.

As already mentioned, the results for 1:2 $\mathrm{Fe}$ (III): citrate ratio at $\mathrm{pH} 3.5$ (Exp. 5, $\left.k_{\mathrm{obs}}=10.7 \times 10^{-3} \mathrm{~min}^{-1}\right)$ and $1: 3 \mathrm{Fe}(\mathrm{III})$ :citrate ratio at $\mathrm{pH} 5.7\left(\right.$ Exp. $1, k_{\mathrm{obs}}=(8.0 \pm 1.8) \times 10^{-3}$ $\min ^{-1}$ ) are quite close. These results suggest that increasing citrate concentration allowed extending the reaction $\mathrm{pH}$ to neutral, since an increase of citrate content in the Fe(III):citrate ratio allows a higher concentration of Fe-citrate species in solution up to pH 7 (APPENDIX F, Figure F5). Similar results were reported by Ou et al. (2008), who used $\mathrm{Fe}(\mathrm{III})$ :citrate ratio of $1: 10$ and showed that atrazine photo-degradation rates promoted by irradiated $\mathrm{Fe}(\mathrm{III})$-citrate complexes exhibited no considerable differences between $\mathrm{pH} 3.5$ and 5.4 .

While in the $\mathrm{Fe}(\mathrm{III})$-oxalate complex the increase of the ligand concentration compensates the inhibitory effect of increasing $\mathrm{pH}$ with an almost linear relationship, this is not observed for the citrate ligand. Actually, the compensation effect related to $\mathrm{pH}$ presents a maximum value at $\mathrm{Fe}(\mathrm{III})$ :citrate ratio between 1:3 and 1:4; after this, an increase in citrate concentration has no effect either on $k_{\mathrm{obs}}$ or on the $\mathrm{pH}$ range extension. 


\subsubsection{AMZ degradation promoted by photooxidation of $\mathrm{Fe}$ (III)-tartrate complex}

Table 11 shows the results of the Doehlert design for the Fe(III)-tartrate system, fixing $[\mathrm{AMZ}]_{0}=41.4 \mu \mathrm{mol} \mathrm{L}{ }^{-1}$ and $[\mathrm{Fe}(\mathrm{III})]_{0}=0.1 \mathrm{mmol} \mathrm{L}^{-1}$. The fitted response surface model is given by Eq. 27. The determination coefficient, $R^{2}$, was equal to 0.980 and the term $\mathrm{pH}^{2}$ showed the most important effect on the observed degradation rate $\left(k_{\mathrm{obs}}, \min ^{-1}\right)$, according to the ANOVA and the Pareto chart $(F$-test with $\mathrm{P}<0.005)$ (APPENDIX F, Table F4 and Figure F6, respectively). It is worth observing that the addition of tartrate to $\mathrm{Fe}(\mathrm{III})$ solution inhibit $\mathrm{AMZ}$ degradation at $\mathrm{pH} 3.5$, and the $k_{\mathrm{obs}}$ values for the $\mathrm{Fe}(\mathrm{III})$ tartrate system are much lower than those obtained for the other two complexes in the whole $\mathrm{pH}$ range studied. These results are shown in Figure 13.

Table 11. Doehlert design matrix for two factors and experimental values of $\mathrm{k}_{\mathrm{obs}}$ for the $\mathrm{Fe}(\mathrm{III})$-tartrate system in the presence of $[\mathrm{AMZ}]_{0}=41.4 \mu \mathrm{mol} \mathrm{L}^{-1}$ and $[\mathrm{Fe}(\mathrm{III})]_{0}=0.1 \mathrm{mmol} \mathrm{L}^{-1}$.

\begin{tabular}{cccc}
\hline Exp. & $\begin{array}{c}\text { Fe(III):tartrate } \\
\text { ratio }\end{array}$ & pH & $\begin{array}{c}\boldsymbol{k}_{\text {obs }} \times \mathbf{1 0}^{\mathbf{3}} \\
\left(\mathbf{m i n}^{-\mathbf{1}}\right)^{\mathbf{a}}\end{array}$ \\
\hline $\mathbf{1}$ & $1: 3$ & 5.7 & 1.4 \\
$\mathbf{1 A}$ & $1: 3$ & 5.7 & 1.1 \\
$\mathbf{1 B}$ & $1: 3$ & 5.7 & 1.0 \\
$\mathbf{2}$ & $1: 5$ & 5.7 & 0.4 \\
$\mathbf{3}$ & $1: 4$ & 8.0 & 1.0 \\
$\mathbf{4}$ & $1: 1$ & 5.7 & 2.0 \\
$\mathbf{5}$ & $1: 2$ & 3.5 & 4.3 \\
$\mathbf{6}$ & $1: 2$ & 8.0 & 0.4 \\
$\mathbf{7}$ & $1: 4$ & 3.5 & 3.2 \\
\hline
\end{tabular}

${ }^{a}$ Calculated for the first 20 minutes of reaction.

$k_{o b s}=18.4-14.5 X_{1}-3.7 X_{2}-0.8 X_{1}^{2}-0.2 X_{2}^{2}+1.9 X_{1} X_{2}$

The highest value of $k_{\mathrm{obs}}$ was obtained for Exp. 5, performed at $\mathrm{pH} 3.5$ with $\mathrm{Fe}(\mathrm{III}):$ tartrate $=1: 2$. In order to validate the tendency observed at $\mathrm{pH} 3.5$, two more experiments were performed: one with $\mathrm{Fe}(\mathrm{III})$ :tartrate ratio of 1:1 and other with 1:10, giving $k_{\text {obs }}$ values of $4.3 \times 10^{-3} \mathrm{~min}^{-1}$ and $4.1 \times 10^{-3} \mathrm{~min}^{-1}$, respectively. These results show 
that there are no significant differences on AMZ degradation for short irradiation times. Similar results are reported in a study developed by Wang et al. (2006), where no significant differences in the generation of ${ }^{\circ} \mathrm{OH}$ radicals were achieved for $\mathrm{Fe}$ (III):tartrate ratios in the range 1:3-1:12 over 60 minutes of irradiation.

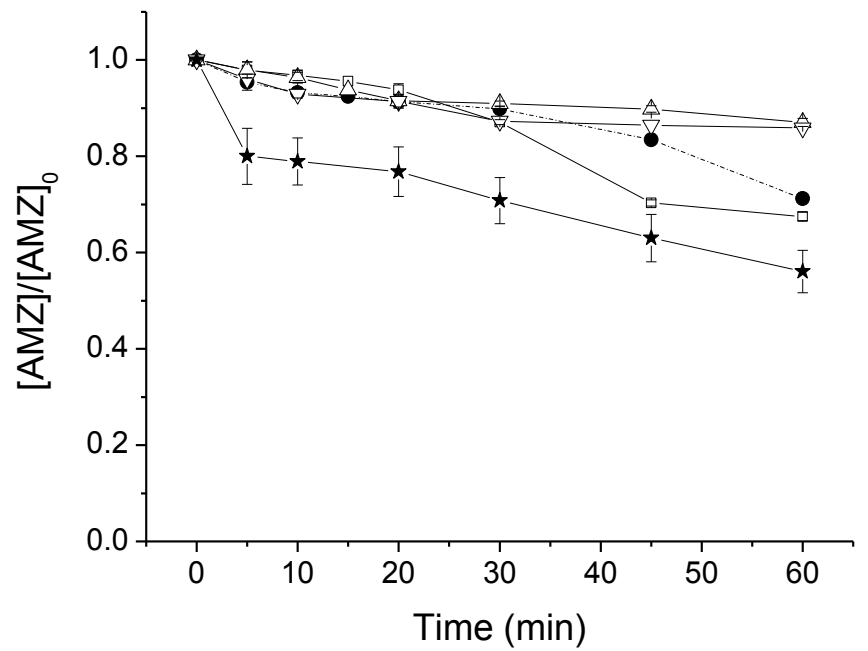

Figure 13. Effect of $\mathrm{Fe}(\mathrm{III})$ :tartrate ratio concentration on $\mathrm{AMZ}$ degradation profile. ( $\star$ ) $-\mathrm{Fe}(\mathrm{III})$ aquacomplex, ( $\square$ ) Fe(III):tartrate= 1:1, (○) Fe(III):tartrate $=1: 2 ;(\triangle) \mathrm{Fe}(\mathrm{III})$ :tartrate $=1: 4,(\nabla)$ $\mathrm{Fe}(\mathrm{III}):$ tartrate $=1: 10 .[\mathrm{AMZ}]_{0}=(41.4 \pm 8.0) \mu \mathrm{mol} \mathrm{L}{ }^{-1}$ and $[\mathrm{Fe}(\mathrm{III})]_{0}=0.1 \mathrm{mmol} \mathrm{L}^{-1}, \mathrm{pH}=3.5$.

According to the predictions based on Visual MINTEQ (APPENDIX F, Figure F7), the molar fraction of Fe-tartrate ${ }^{+}$species increases by increasing the tartrate content in the $\mathrm{Fe}(\mathrm{III})$ :tartrate ratio. $\mathrm{Fe}$-tartrate ${ }^{+}$is the most photoactive complex in the $\mathrm{pH}$ range from 3 to 5 (WANG et al., 2006). For $\mathrm{pH}$ values higher than 5, the percent concentration of Fe-tartrate ${ }^{+}$approaches zero, explaining the almost unmeasurable $\mathrm{k}_{\mathrm{obs}}$ obtained under such conditions. However, in spite of increasing photoactive species concentration in solution, increasing tartrate concentration did not result in higher $\mathrm{k}_{\mathrm{obs}}$ values, since the excess of free tartrate ions can act as ${ }^{\circ} \mathrm{OH}$ scavengers (WANG et al., 2006). In light of these considerations, we can say that the response surface and contour plots (Figure 14) given by Eq. 27 provide acceptable predictions based on experimental results. Notwithstanding, it is worth mentioning that the $k_{\text {obs }}$ value obtained from the experiment performed with a $\mathrm{Fe}(\mathrm{III})$ :tartrate ratio of $1: 10$ at $\mathrm{pH} 3.5$ is not predicted by the model of Eq.27, since it is outside the design domain. 
A

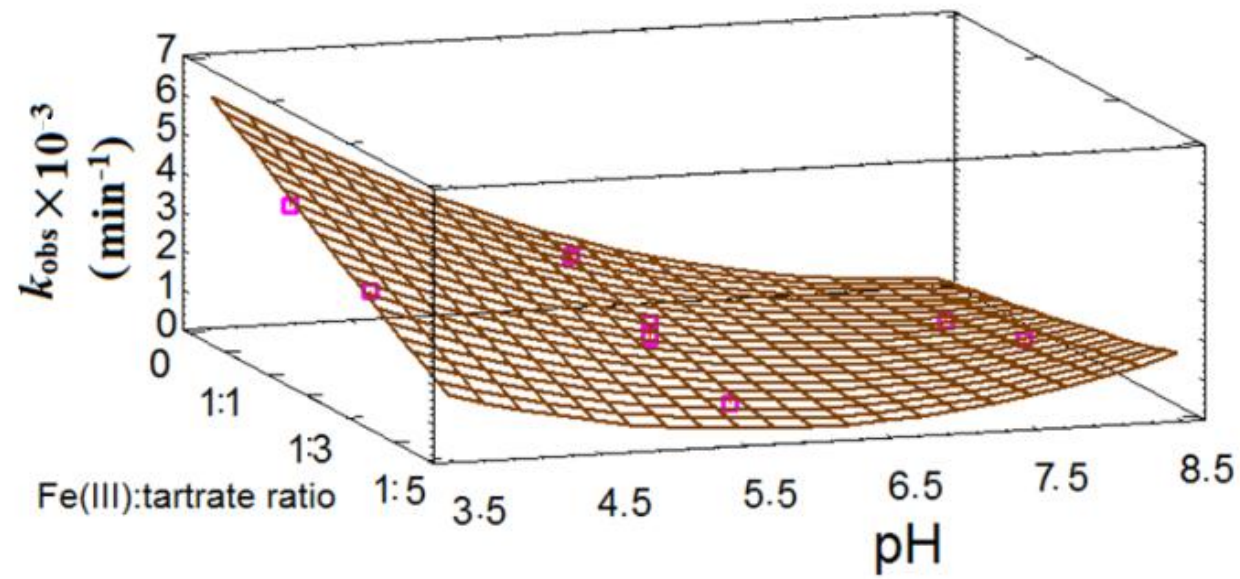

B

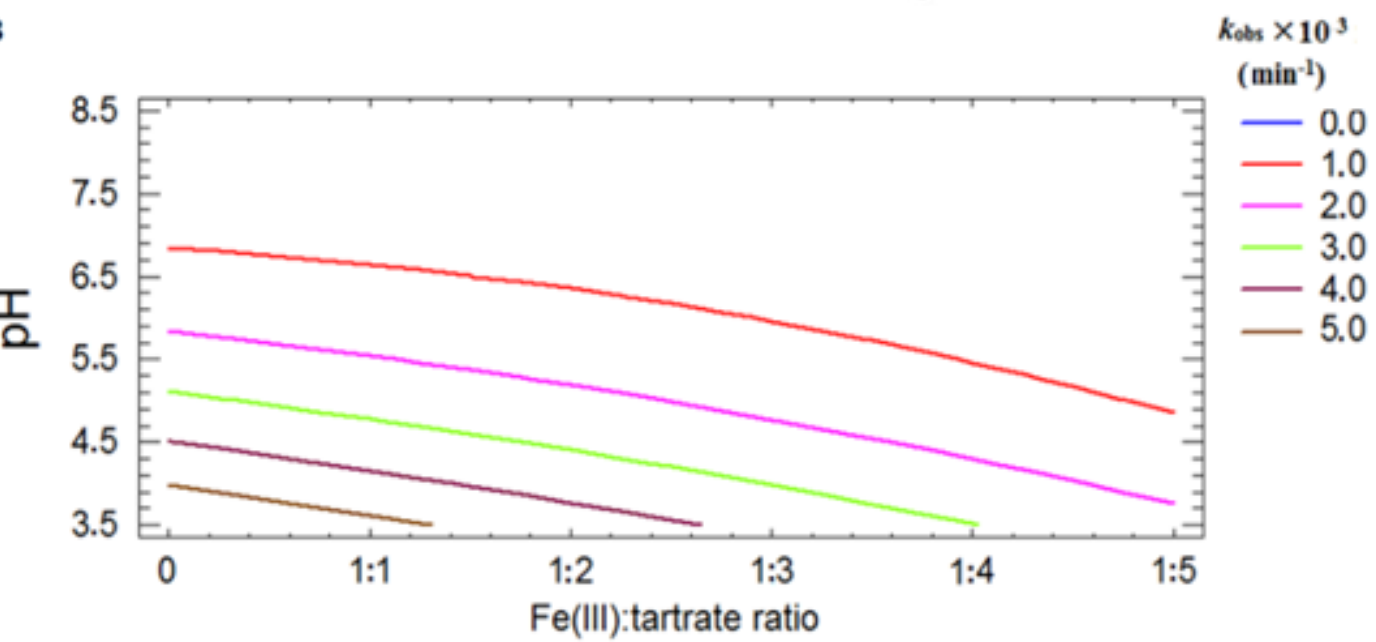

Figure 14. (A) Response surface including the experimental points (pink dots) and (B) contour plot for $k_{\mathrm{obs}}$, varying the $\mathrm{Fe}(\mathrm{III})$ :tartrate ratio from 0 to $1: 5$ and $\mathrm{pH}$ from 3.5 to 8.5.

\subsubsection{Comparison between the best conditions}

\subsubsection{Photo generated $\mathrm{Fe}(\mathrm{II}), \mathrm{H}_{2} \mathrm{O}_{2}$ and ${ }^{\circ} \mathrm{OH}$}

The concentrations of photo-generated $\mathrm{H}_{2} \mathrm{O}_{2}, \mathrm{Fe}(\mathrm{II})$ and ${ }^{\circ} \mathrm{OH}$ were measured for the best conditions found for each complex, i.e. Fe(III):ligand ratios of 1:10 for Fe(III)oxalate, 1:4 for $\mathrm{Fe}(\mathrm{III})$-citrate and 1:1 for $\mathrm{Fe}(\mathrm{III})$-tartrate, at $\mathrm{pH} 3.5$ and at a fixed $[\mathrm{Fe}(\mathrm{III})]_{0}$ of $0.1 \mathrm{mmol} \mathrm{L}^{-1}$.

Control experiments in the absence of ligands were carried out for the three $\mathrm{pH}$ values studied. We observed that UVA-irradiated Fe(III) at $\mathrm{pH} 3.5$ achieves $33 \% \mathrm{AMZ}$ removal after 60 minutes, with $k_{\mathrm{obs}}=12.9 \times 10^{-3} \mathrm{~min}^{-1}$. This result was expected, since in the absence of any other ligand, Fe(III) species can complex with water and/ or hydroxide anions, forming hidroxy-aqua complexes such as $\left[\mathrm{Fe}^{\mathrm{III}} \mathrm{OH}\left(\mathrm{H}_{2} \mathrm{O}\right)_{5}\right]^{2+}$, which is the predominant species at $\mathrm{pH} \sim 3$. This complex undergoes LMCT (ligand to metal charge transfer) under sunlight irradiation, as well as under UVA irradiation (see Figure D2, APPENDIX D), which is followed by inner-sphere photoinductive electron transfer, 
producing the $\mathrm{Fe}(\mathrm{II})$-aqua complex and one ${ }^{\circ} \mathrm{OH}$ radical (Eq. 18) (CIEŚLA et al., 2004). As expected, in the other two control runs for $\mathrm{pH} 5.7$ and 8.0 no AMZ degradation was observed since free iron species are not soluble under these conditions.

Table F5 in APPENDIX $\mathbf{F}$ provides the relative reactivity of different Fe(III) complexes (in terms of $k_{\text {obs }} \mathrm{Fe}(\mathrm{III})$-carboxylate $/ k_{\mathrm{obs}} \mathrm{Fe}(\mathrm{III})$-aquacomplex) for different $\mathrm{Fe}(\mathrm{III})$ :ligand ratios at $\mathrm{pH} 3.5$, at which the $\mathrm{Fe}(\mathrm{III})$-aquacomplex can degrade AMZ. It is evident that all $\mathrm{Fe}(\mathrm{III})$ complexes (including aquacomplexes) perform better than $\mathrm{Fe}(\mathrm{III})$ tartrate, as discussed hereinafter.

In Figure 15, the results of the measured $\mathrm{Fe}(\mathrm{II})$ and ${ }^{\circ} \mathrm{OH}$ generation from $\mathrm{Fe}(\mathrm{III})-$ aquacomplex solutions, in the presence of $\mathrm{AMZ}$ or benzene, respectively, are presented. As verified, $\mathrm{Fe}(\mathrm{II})$ concentration reached a steady state condition in 10 minutes of reaction, while ${ }^{\circ} \mathrm{OH}$ concentration increased continuously. This can be explained by considering the formation of $\mathrm{Fe}(\mathrm{II})$ from the photo-induced reduction of the $\mathrm{Fe}(\mathrm{III})$ aquacomplex and its simultaneous oxidation back to Fe(III) through dissolved oxygen $\left(\mathrm{O}_{2}\right)$ and other reactive species (e.g., ${ }^{\circ} \mathrm{OH}, \mathrm{HO}_{2}{ }^{\circ}, \mathrm{O}_{2}{ }^{-}$radicals) (CORREIA DE VELOSA; PUPO NOGUEIRA, 2013; PIGNATELLO; OLIVEROS; MACKAY, 2006). In contrast, ${ }^{\circ} \mathrm{OH}$ radicals are continuously produced since the $\mathrm{Fe}(\mathrm{III})$-aquacomplex is continuously regenerated and photolyzed .

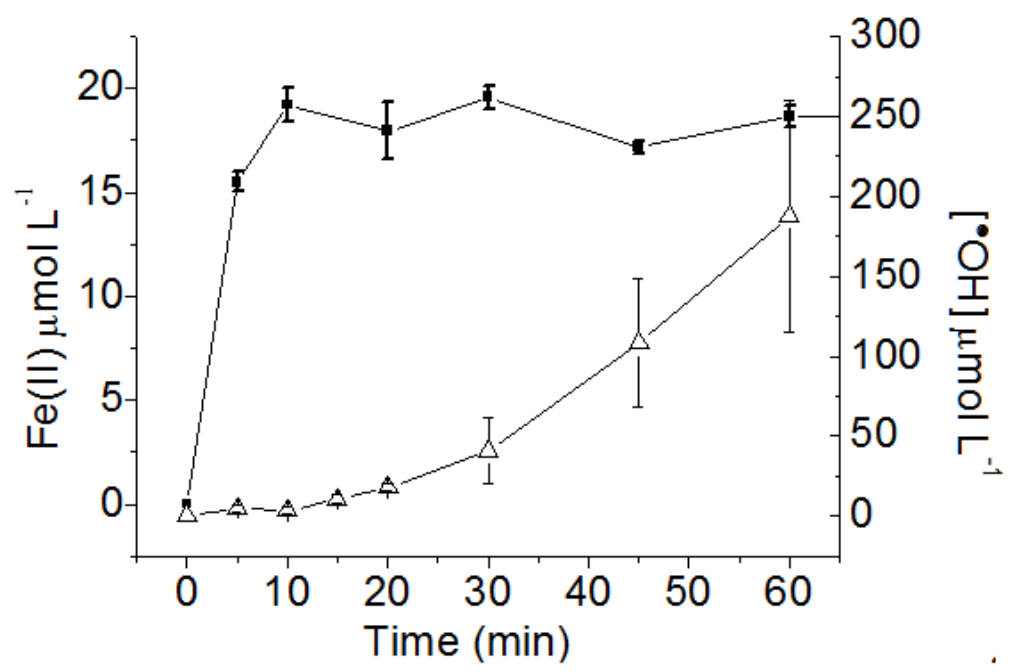

Figure 15. Formation of $\mathrm{Fe}(\mathrm{II})$ ( $\boldsymbol{\bullet}$, left scale, during AMZ degradation) and ${ }^{\circ} \mathrm{OH}$ ( $\triangle$ right scale, in the presence of benzene) from irradiated $\mathrm{Fe}(\mathrm{III})$-aquacomplex at $\mathrm{pH} 3.5$. [AMZ] $]_{0}=41.4 \mu \mathrm{mol} \mathrm{L}^{-1}$ and $[\mathrm{Fe}(\mathrm{III})]_{0}=0.1 \mathrm{mmol} \mathrm{L}^{-1}$.

In the presence of organic ligands, such as carboxylates, there is another photochemical mechanism for generating ${ }^{\circ} \mathrm{OH}$ radicals. In such systems, ${ }^{\circ} \mathrm{OH}$ is generated 
only by the Fenton reaction (Eq. 22) which depends on the generation of $\mathrm{H}_{2} \mathrm{O}_{2}$ (Eq. 21).

$\mathrm{H}_{2} \mathrm{O}_{2}$ and $\mathrm{Fe}(\mathrm{II})$ concentrations over time, during the irradiation of each Fe:ligand system, are presented in Figures $16 \mathrm{~A}$ and $\mathrm{B}$, respectively while AMZ abatement and the production of ${ }^{\circ} \mathrm{OH}$ radicals are presented in Figure 16C. All the experiments were performed at the best experimental conditions indicated by the response surfaces discussed in the previous sections. AMZ degradation profiles observed for each complex can be supported by these measurements.
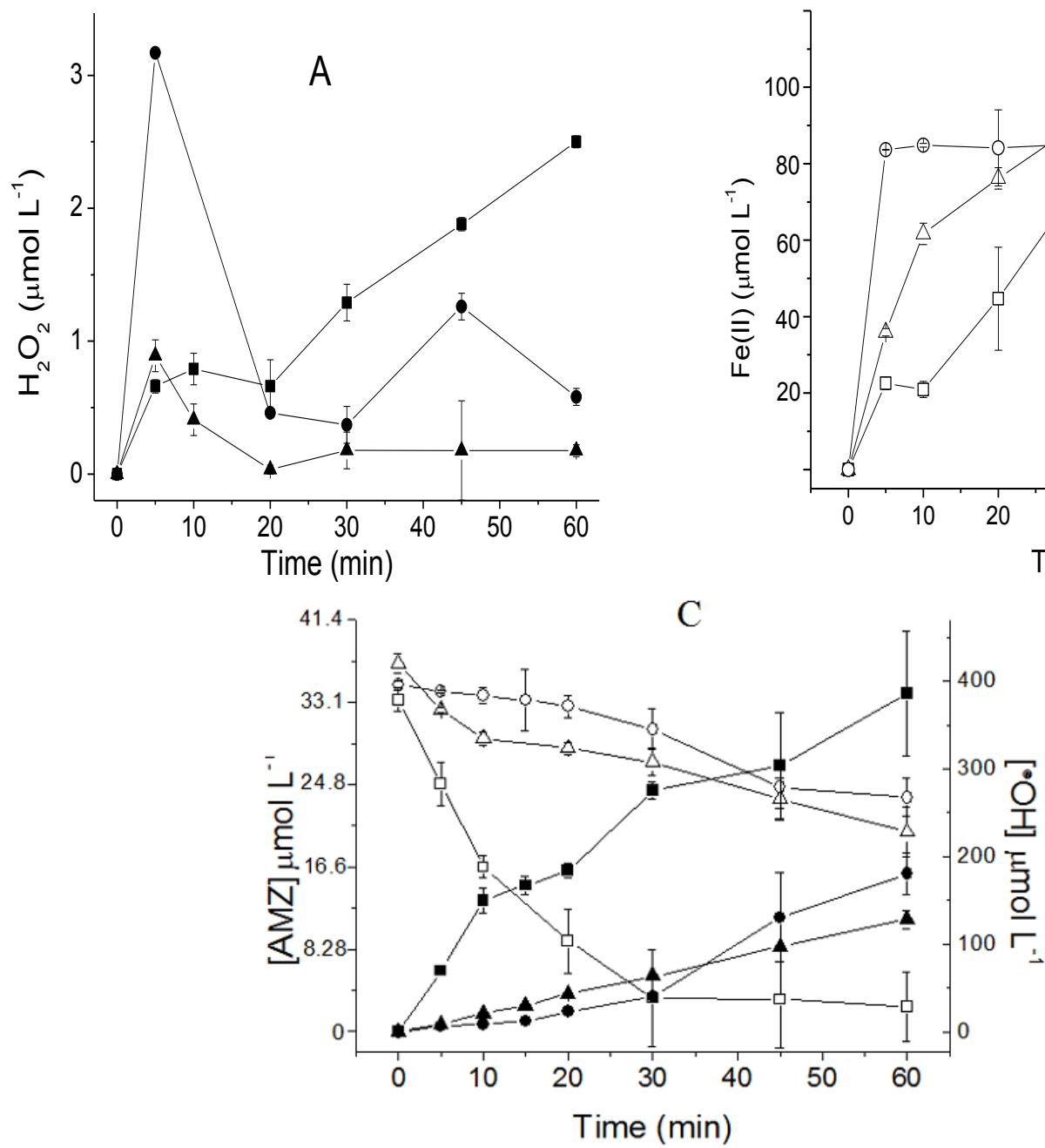

$\mathrm{C}$
B

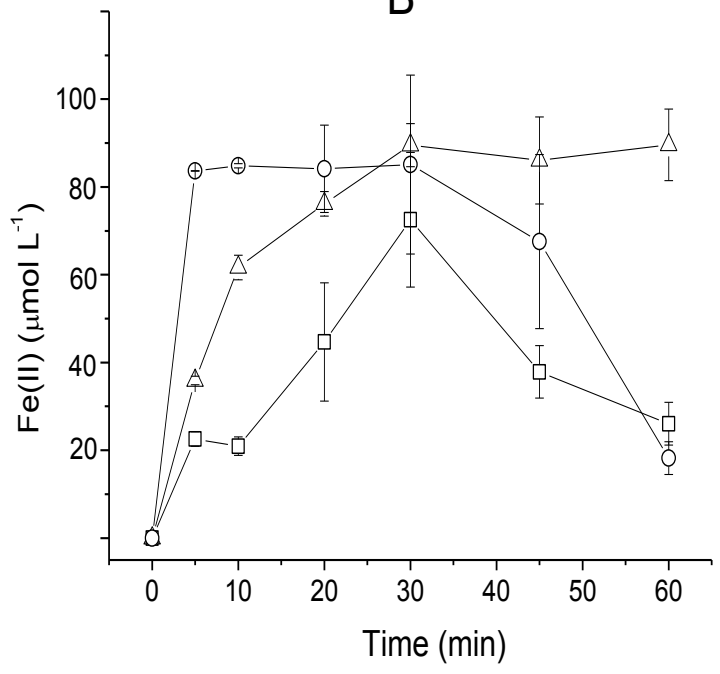


rate of $\mathrm{H}_{2} \mathrm{O}_{2}$ production (Eq. 21). Table 12 summarizes these two parameters for each complex studied.

Table 12. Production quantum yields of $\mathrm{Fe}(\mathrm{II})(\phi(+\mathrm{Fe}(\mathrm{II}))$ and rate of reaction in Eq.20 for each $\mathrm{Fe}(\mathrm{III})$ :carboxylate complex studied).

\begin{tabular}{ccccc}
\cline { 2 - 5 } & Fe(III)-oxalate & Fe(III)-citrate & $\begin{array}{c}\text { Fe(III)- } \\
\text { tartrate }\end{array}$ & $\begin{array}{c}\text { Fe(III)-aquacomplex } \\
\left(\mathbf{F e}(\mathbf{O H})^{2+}\right)\end{array}$ \\
\hline$\Phi(+\mathbf{F e}(\mathbf{I I}))$ & $1.25^{\mathrm{a}} ; 0.32^{\mathrm{b}}$ & $0.45^{\mathrm{b}} ; 0.23^{\mathrm{c}}$ & $0.58^{\mathrm{b}} ; 0.4^{\mathrm{d}}$ & $0.1^{\mathrm{e}}$ \\
\hline
\end{tabular}

\section{Reaction}

\begin{tabular}{|c|c|c|c|c|}
\hline rate & $2.4 \times 10^{9 \mathrm{f}}$ & $1.0 \times 10^{6 c}$ & Data not & Not applied \\
\hline constant & $\mathrm{L} \mathrm{mol}^{-1} \mathrm{~s}^{-1}$ & $\mathrm{~L} \mathrm{~mol}^{-1} \mathrm{~s}^{-1}$ & found & \\
\hline
\end{tabular}

(Eq. 20)

${ }^{\mathrm{a}}$ Goldstein and Rabani (2008) (unspecified $\mathrm{pH} ;$ Fe:ligand ratio $\left.=1: 3, \lambda_{\mathrm{ex}}=270-365 \mathrm{~nm}\right) ;{ }^{\mathrm{b}}$ Abrahamson, Rezvani and
Brushmiller, $(1994)\left(\mathrm{pH}=4 ;\right.$ Fe:ligand ratio $=1: 5 ; \lambda_{\mathrm{ex}}=366 \mathrm{~nm} ;{ }^{\mathrm{c}}$ Ou et al. $(2008)(\mathrm{pH}=3.5 ;$ Fe:ligand ratio $=1: 10 ;$
$\left.\lambda_{\mathrm{ex}}=436 \mathrm{~nm}\right) .{ }^{\mathrm{d}}$ Glebov et al. $(2011)\left(\mathrm{pH}=3 ; \mathrm{Fe}:\right.$ ligand ratio $\left.=1: 1 ; \lambda_{\mathrm{ex}}=350 \mathrm{~nm}\right) ;{ }^{\mathrm{e}}$ Lee and Yoon $(2004)(\mathrm{pH} \leq 1.7$
$\left.\lambda_{\mathrm{ex}}=340-360 \mathrm{~nm}\right) ;{ }^{\mathrm{f}}$ Balmer and Sulzberger $(1999)\left(\mathrm{pH} 3\right.$, various Fe:ligand ratios, $\left.300 \mathrm{~nm}<\lambda_{\mathrm{ex}}<500 \mathrm{~nm}\right)$.

In the case of the $\mathrm{Fe}(\mathrm{III})$-oxalate complex, Figure 15 shows that $\mathrm{Fe}(\mathrm{II})$ concentration grows up to 30 minutes and then decreases, while $\mathrm{H}_{2} \mathrm{O}_{2}$ and ${ }^{\circ} \mathrm{OH}$ concentrations both increase continuously over time (Figures 16A and 16C, respectively). This can be rationalized considering that $\mathrm{Fe}(\mathrm{II})$ production surpasses its consumption in the first 30 minutes of reaction until complete decarboxylation of the $\mathrm{Fe}$ (III)-oxalate complex (Eq. 19). This result is in accordance with other investigations that have reported half-lives of few minutes for $\mathrm{Fe}(\mathrm{III})$-carboxylate complexes under UVA radiation (FAUST; ZEPP, 1993b; MOREIRA et al., 2015; ZUO; JÜRG, 1992). As the carboxylate is consumed (Eq. 20), speciation diagrams reveal that the $\mathrm{Fe}(\mathrm{OH})^{2+}$ aquacomplexes increase in importance (APPENDIX F, Figure F3); these species undergo photoreduction (Eq. 18), generating $\mathrm{Fe}(\mathrm{II})$ at a much lower quantum yield, which is then consumed by the Fenton reaction (Eq. 22). In turn, $\mathrm{H}_{2} \mathrm{O}_{2}$ concentration is expected to decrease after a longer time since its consumption by the Fenton reaction will surmount its generation by the reactions given by Eqs. 20-21.

Similarly, in the case of the $\mathrm{Fe}$ (III)-citrate complex, the accumulation of $\mathrm{Fe}(\mathrm{II})$ over time can rely on the same differences regarding reaction rates. However, the quantum yield of generation of $\mathrm{Fe}$ (II) usually reported for this complex is lower than that reported for the Fe(II)-oxalate complex. Moreover, the second-order rate constant of the 
reaction between the citrate radical and oxygen (Eq. 20) is also smaller than that observed for the oxalate radical (Table 12). Therefore, less $\mathrm{H}_{2} \mathrm{O}_{2}$ is produced (as can be verified in Figure $15 \mathrm{~A}$ ), resulting in lower ${ }^{\circ} \mathrm{OH}$ production according to Eq. 22.

We hypothesize that the behavior of the Fe(III)-tartrate complex is quite similar to that of the $\mathrm{Fe}$ (III)-citrate complex but with faster reaction rates both for the consumption and the formation of $\mathrm{Fe}(\mathrm{II})$, since a higher $\Phi(+\mathrm{Fe}(\mathrm{II}))$ is reported for the former. This would explain the almost instantaneous high production of $\mathrm{Fe}$ (II) and $\mathrm{H}_{2} \mathrm{O}_{2}$ achieved. However, after 5 minutes, $\mathrm{Fe}(\mathrm{II})$ concentration remains constant over 25 minutes, then decreases, while $\mathrm{H}_{2} \mathrm{O}_{2}$ concentration drops abruptly. Based on the consumption of $\mathrm{Fe}(\mathrm{II})$ and $\mathrm{H}_{2} \mathrm{O}_{2}$ observed during the irradiation of the $\mathrm{Fe}(\mathrm{III})$-tartrate complex, more ${ }^{\circ} \mathrm{OH}$ radicals would had been formed and, as a consequence, a higher AMZ removal was expected. This was also observed during the $\mathrm{Fe}$ (III)-oxalate photolysis, helping to explain the high AMZ degradation achieved. In fact, Figure 16C shows that a little higher amount of ${ }^{\circ} \mathrm{OH}$ radicals were produced after 60 minutes through the photolysis of $\mathrm{Fe}(\mathrm{III})$-tartrate in comparison with $\mathrm{Fe}(\mathrm{III})$-citrate; surprisingly, less AMZ was degraded through Fe(III)-tartrate photolysis. However, considering the experimental error involved, it is not possible to confirm that significant differences exist between citrate and tartrate towards AMZ degradation following the generation of hydroxyl radicals by each $\mathrm{Fe}(\mathrm{III})$ complex at $\mathrm{pH}$ 3.5. Although no data was found for the second-order rate constant of the reaction given by Eq.20 regarding the Fe(III)-tartrate complex, Xianghua et al., 2013 reported that during Fe(III)-tartrate irradiation the production of $\mathrm{Fe}(\mathrm{II})$ was far faster than that of ${ }^{\circ} \mathrm{OH}$ radicals. Therefore, according to these authors, longer irradiation times would be required to achieve higher AMZ removals.

Another important factor that can help to understand our results is the reactivity between $\mathrm{Fe}$ (II)-carboxylates and $\mathrm{H}_{2} \mathrm{O}_{2}$. For all the Fe:ligand ratios studied there is a certain amount of free carboxylate available to complex with $\mathrm{Fe}(\mathrm{II})$ produced from $\mathrm{Fe}(\mathrm{III})$-carboxylates photolysis (Eq.19). As stated in the literature, Fe(II)-oxalate reacts much faster with $\mathrm{H}_{2} \mathrm{O}_{2}$ than uncomplexed $\mathrm{Fe}(\mathrm{II})$, yielding ${ }^{\circ} \mathrm{OH}$ radicals fast as well (PARK et al., 1997). In the case of Fe(II)-citrate recent studies suggest that not only the reaction rate constant between this complex and $\mathrm{H}_{2} \mathrm{O}_{2}$ is much lower than that reported for Fe(II)-oxalate and uncomplexed Fe(II) (MILLER; ROSE; WAITE, 2016), but also radicals with lower oxidation potentials than ${ }^{\circ} \mathrm{OH}$ radicals are formed (KORNWEITZ; BURG; MEYERSTEIN, 2015). Similar studies were not found for Fe(II)-tartrate. 
Notwithstanding from the results obtained in the present study we believe that this complex will behave similarly to Fe(II)-citrate, although further investigation is needed.

Although the photolysis of the three Fe(III)-carboxylate complexes studied promoted AMZ degradation at $\mathrm{pH} 3.5$, only the best conditions found for $\mathrm{Fe}$ (III)-oxalate and $\mathrm{Fe}(\mathrm{III})$-citrate achieved better or similar AMZ removals after 60 minutes of irradiation than that observed for the Fe(III)-aquacomplex, respectively. In turn, also these two $\mathrm{Fe}(\mathrm{III})$-carboxylates enabled $\mathrm{AMZ}$ degradation at circumneutral $\mathrm{pH}$, where iron would normally precipitate. Besides, Fe(III)-oxalate enabled AMZ degradation under alkaline conditions $(\mathrm{pH}=8)$, which, to the best of our knowledge, was never verified before but is indeed very important to the self-depuration of waterbodies.

\subsubsection{Influence of real water constituents}

Although carboxylates have been extensively applied in many studies to represent natural organic matter (NOM), the presence of other substances besides carboxylates, in natural waters, has also to be taken into account when evaluating the environmental fate of contaminants. Given that, additional experiments using a real water sample were performed, in order to analyze the influence of other natural water constituents in AMZ degradation promoted by Fe(III)-carboxylate complexes. With this aim, we sampled the treated effluent of a sewage treatment plant located in São Paulo, Brazil. This matrix contains solubilized material discarded in waterbodies, impacting their natural characteristics (see Section 5.1). The water sample was spiked with AMZ (10 mg L $\mathrm{L}^{-1}$ ) and irradiated for $60 \mathrm{~min}$, in the presence of each Fe(III) complex studied, at the best $\mathrm{Fe}(\mathrm{III})$ :ligand ratio found for each complex: 1:10 (Fe(III):oxalate), 1:4 (Fe(III):citrate), and 1:1 (Fe(III):tartrate). The same three $\mathrm{pH}$ values (3.5, 5.7, and 8.0) were tested, excepting the case when the $\mathrm{Fe}(\mathrm{III})$-aquacomplex was considered, in which case only $\mathrm{pH}$ 3.5 was used, due to iron precipitation above that $\mathrm{pH}$ value.

For all the Fe(III)-carboxylates, AMZ degradation in real water was worse than in deionized water, except tartrate, for which similar $[\mathrm{AMZ}] /[\mathrm{AMZ}]_{0}$ time-evolutions were obtained (Figure 17). In deionized water containing carboxylates, Fe(III) can only form aquacomplexes and/or Fe(III)-carboxylate complexes, which we have already proved to effectively degrade AMZ under UVA radiation. On the other hand, the organic matter $(\mathrm{OM})$ in the real water sample $\left(\mathrm{TOC}=20 \mathrm{mg} \mathrm{L}^{-1}\right.$ ) can compete for ${ }^{\circ} \mathrm{OH}$ radicals, possibly explaining the lower AMZ removal rates obtained. Actually, depending on its composition, $\mathrm{OM}$ can behave as an inner light filter, hydroxyl radicals quencher, and also 
as a source of additional oxidizing species (like singlet oxygen, ${ }^{1} \mathrm{O}_{2}$; excited triplet states of organic matter, ${ }^{3} \mathrm{OM}^{*}$; and ${ }^{\circ} \mathrm{OH}$ radicals (OPPENLÄNDER, 2003)). Therefore, the overall AMZ photodegradation behavior is a result of these opposite roles played by OM. Furthermore, the presence of high concentrations of $\mathrm{Cl}^{-}\left(70.6 \mathrm{mg} \mathrm{L}^{-1}\right)$ and $\mathrm{SO}_{4}{ }^{2-}(44.8 \mathrm{mg}$ $\left.\mathrm{L}^{-1}\right)$ in the real water sample may also have interfered with AMZ degradation, since these ions are known not only for forming less photoactive complexes with $\mathrm{Fe}(\mathrm{III})$, thus affecting the distribution and the reactivity of iron species, but also for quenching ${ }^{\circ} \mathrm{OH}$ radicals (BENKELBERG; WARNECK, 1995; LAAT; LE; LEGUBE, 2004). Moreover, the inorganic carbon content of the real water $\left(\mathrm{IC}=20.7 \mathrm{mg} \mathrm{L}^{-1}\right)$ is associated with high $\mathrm{CO}_{3}{ }^{2-}$ and/or $\mathrm{HCO}_{3}{ }^{-}$contents, which are well known scavenging species (OPPENLÄNDER, 2003).

It is worth mentioning that no significant AMZ removal by direct photolysis was observed up to $120 \mathrm{~min}$ of irradiation in real water, suggesting that the amount of iron species originally present $\left(0.111 \mathrm{mg} \mathrm{L}^{-1}\right.$ total $\left.\mathrm{Fe}\right)$ was not enough to overcome inner filter effects and side-scavenging reactions. However, when solely Fe(III) was spiked, AMZ degradation occurred slightly faster in real water than in deionized water (Figure 17D). In this case, we hypothesize that stable photoactive $\mathrm{Fe}(\mathrm{III})-\mathrm{OM}$ complexes and aquacomplexes would be formed in the presence of excess Fe(III), thus favoring AMZ removal. In contrast, when Fe(III)-carboxylate complexes are added to real water, not only the iron content is increased but also the TOC content, and its associated undesirable side effects. 
A1) Fe(III)-oxalate $\mathrm{pH} 3.5$

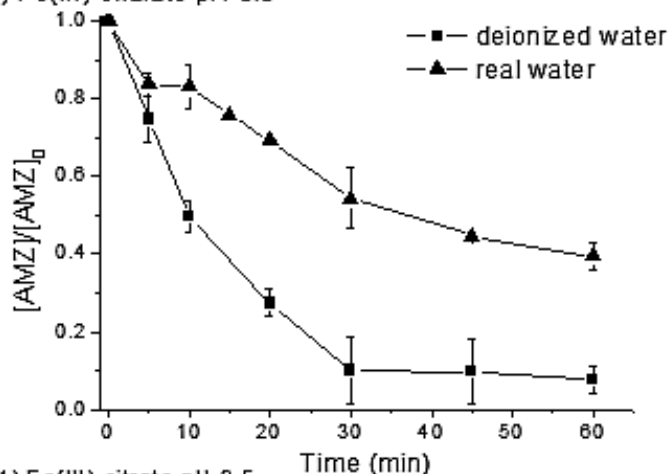

B 1) $\mathrm{Fe}$ (III)-citrate $\mathrm{pH} 3.5 \quad$ Time (min)

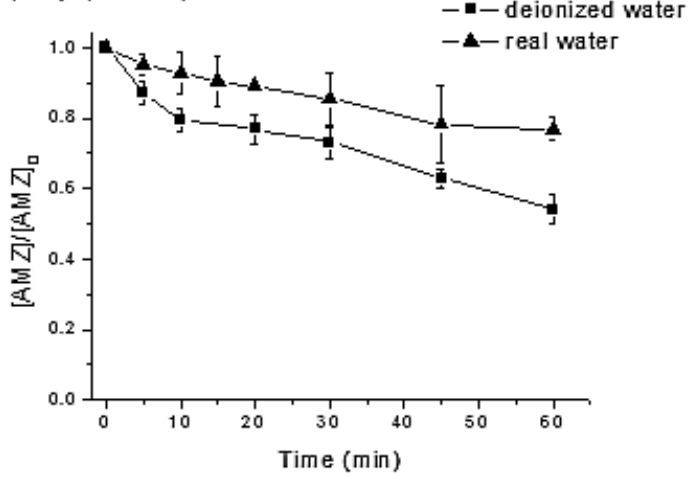

C1) Fe(III)-tartrate pH $3.5 \quad-\mathbf{- 1}$-deionized water

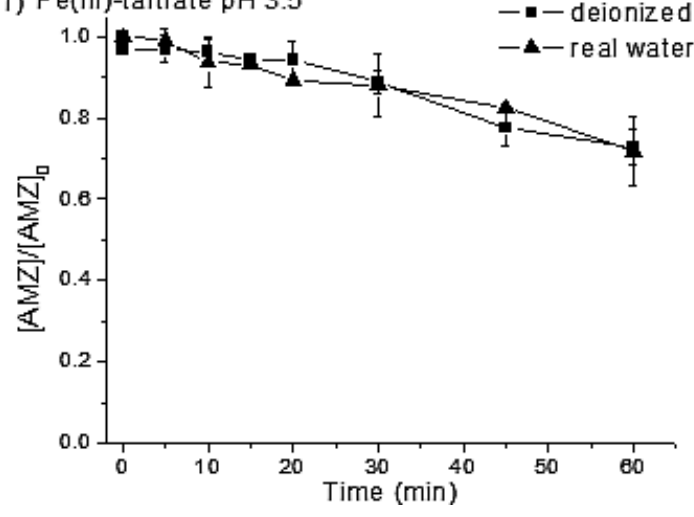

A2) Real water

- - $-\mathrm{pH} 3.5$
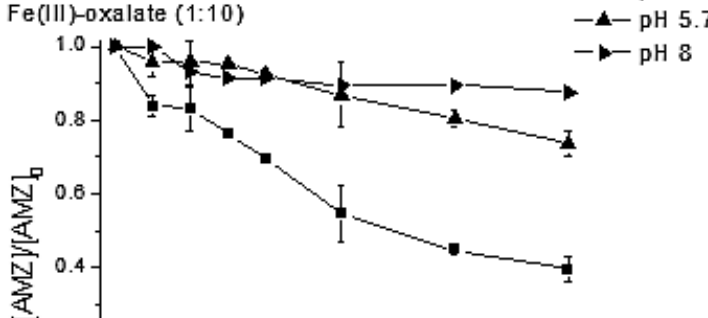

द्य.

0.2

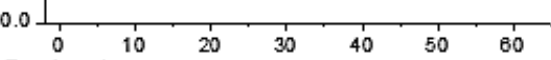

B2) Real water Time (min) $\quad-m-\mathrm{pH} 3.5$

Fe(III)-citrate (1:4) - $\quad$ - $-\mathrm{pH} 5.7$

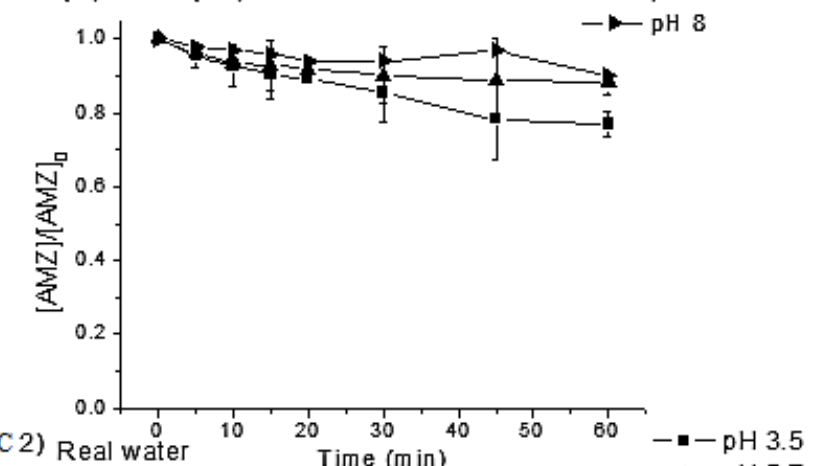

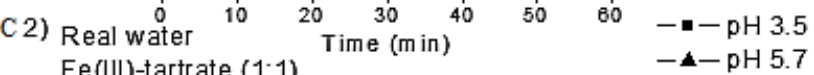

$\mathrm{Fe}(\mathrm{III})$-tartrate (1:1) $\mathrm{I}-\mathrm{pH}$

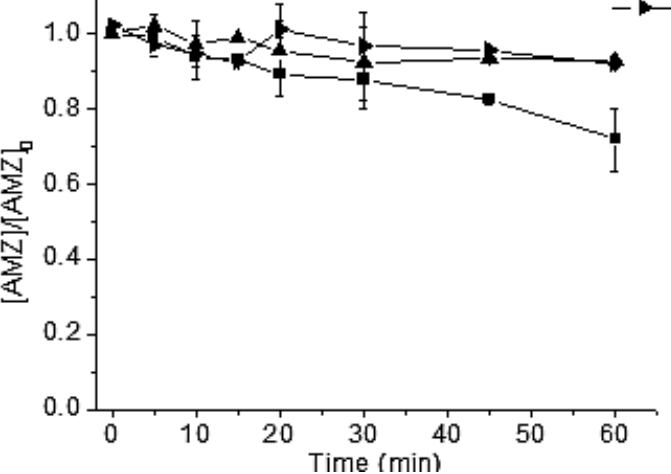

D) Fe(III)-aquacomplex

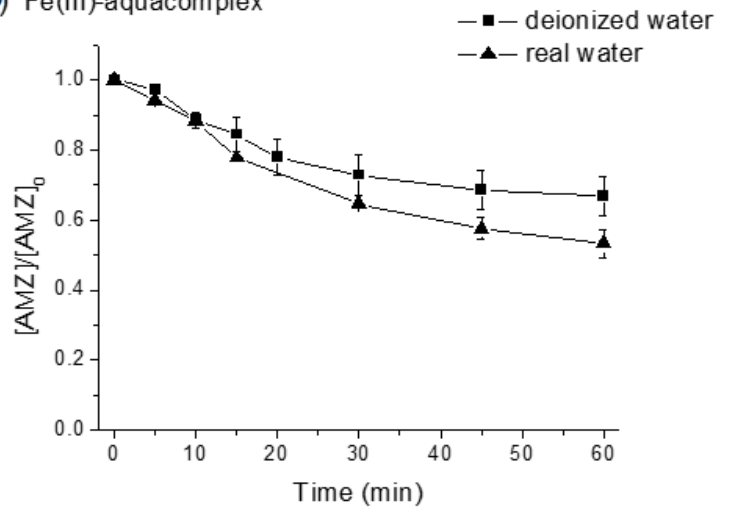

Figure 17. Comparison between AMZ degradation promoted by A1) Fe(III)-oxatale (1:10), B1) Fe(III)citrate (1:4) and $\mathrm{C} 1) \mathrm{Fe}(\mathrm{III})$-tartrate (1:1) photolysis in deionized water and real water, for 1:10 (Fe(III):oxalate), 1:4 (Fe(III):citrate), and 1:1 (Fe(III):tartrate). A2), B2) and C2) correspond to the same experiments in real water, but varying $\mathrm{pH}$. D) $\mathrm{Fe}(\mathrm{III})$-aquacomplex photolysis in deionized water and real water at $\mathrm{pH}$ 3.5. In all the experiments, $[\mathrm{AMZ}]_{0}=(41.4 \pm 8) \mu \mathrm{mol} \mathrm{L}^{-1} ;[\mathrm{Fe}]_{0}=0.1 \mathrm{mmol} \mathrm{L}^{-1}$. 
Previous mathematical simulations predicted that AMZ half-life time in natural waters fall in a timescale of days, depending on water constituents, especially the dissolved organic matter content (Silva et al., 2015). However, the model used by the authors for such predictions (BODRATO; VIONE, 2014) does not consider the influence of Fe(III)-complexes at different $\mathrm{pH}$ values, which we showed to decrease AMZ half-life times. Based on the $k_{\text {obs }}$ values, we estimated AMZ half-lives in a timescale of hours, even under nearly natural $\mathrm{pH}$ in the case of $\mathrm{Fe}(\mathrm{III})$-oxalate and $\mathrm{Fe}(\mathrm{III})$-citrate complexes (about $2.3 \mathrm{~h}$ and 6.4 for $\mathrm{Fe}(\mathrm{III})$-oxalate and $\mathrm{Fe}(\mathrm{III})$-citrate, respectively, at $\mathrm{pH}$ 5.7). Accordingly, these results suggest that mathematical models developed to predict the photochemical environmental fate of emerging pollutants in natural waterbodies would greatly benefit by considering the reactions involving the photolysis of $\mathrm{Fe}$ (III)carboxylates.

\subsection{Partial conclusions}

The use of a response surface model allowed studying the simultaneous effect of the $\mathrm{Fe}(\mathrm{III})$ :carboxylate ratio and $\mathrm{pH}$ on $\mathrm{AMZ}$ degradation. Quantification of photoproduced $\mathrm{Fe}(\mathrm{II}), \mathrm{H}_{2} \mathrm{O}_{2}$ and ${ }^{\circ} \mathrm{OH}$ radicals during irradiation of the $\mathrm{Fe}(\mathrm{III})$-carboxylates helped to substantiate our results. The highest AMZ removals were achieved with a $\mathrm{Fe}(\mathrm{III})$ :ligand ratio of $1: 10$ for $\mathrm{Fe}(\mathrm{III})$ :oxalate, 1:4 for $\mathrm{Fe}(\mathrm{III})$ :citrate, and 1:1 for $\mathrm{Fe}(\mathrm{III})$ :tartrate, all at $\mathrm{pH} 3.5$. However, even at the best condition found for $\mathrm{Fe}(\mathrm{III})$ tartrate, AMZ removal was not as efficient as that obtained through the $\mathrm{Fe}(\mathrm{III})$ :aquacomplex photolysis.

The solution $\mathrm{pH}$ plays an essential role in all the systems studied, since it is directly related to iron speciation, which is a key parameter in the photolysis reaction. We verified that oxalate and citrate complexes enable $\mathrm{AMZ}$ degradation even at high $\mathrm{pH}$ values (pH 5.7 for both and pH 8 only for the Fe(III)-oxalate complex), both in deionized and real water matrixes, although with a worse performance in the latter. Also, our study proved that $\mathrm{AMZ}$ persistence in the environment due to its resistance to direct photolysis can be dramatically decreased by Fe(III)-carboxylates photolysis, especially Fe(III)oxalate, with half-lives falling into a timescale of hours. Knowing that reactions between ${ }^{\circ} \mathrm{OH}$ radicals and organic targets generally follow second-order kinetics; the amount of pesticide will also influence the degradation rate. Therefore, environmental AMZ concentrations would probably decay faster in natural waterbodies. Besides further 
investigation is needed to address this issue, this study provides a good understanding of the role of $\mathrm{Fe}(\mathrm{III})$-carboxylates towards pollutants removal in natural waterbodies. 


\section{EVALUATION OF AMICARBAZONE TOXICITY REMOVAL THROUGH DEGRADATION PROCESSES BASED ON ${ }^{\circ} \mathrm{OH}$ AND $\mathrm{SO}_{4}{ }^{\circ-} \mathrm{RADICALS}^{\circ}$}

Pesticides are known to contaminate both ground and surface waterbodies by processes such as leaching and runoff, consisting in a threat especially to the aquatic biota. Researches devoted to studying the effect of pesticides in a variety of biota proved that pesticides commonly detected in the aquatic environment are present at likely harmful levels to most plants and animal species (FARRUGGIA et al., 2016).

Depending on the frequency at which some pesticides are found and on their potential threat to human health, a pesticide application can be prohibited or limited. This was the case of atrazine, one of the most applied herbicides in the United States of America. Due to its toxic effect towards several organisms and to the environmental concentrations surpassing the accepted levels, atrazine was banned in Europe (SASS; COLANGELO, 2006). Therefore, an effort has been made to replace this herbicide by less hazardous alternatives.

In this context, the amicarbazone (AMZ) herbicide appears as a possible alternative to atrazine, since it is effective against a similar weed spectrum, with the advantage of having lower toxicity (EPA, 2005a; KRÄMER; SCHIRMER, 2012). However, as already mentioned, AMZ can persist in the environment due to its resistance to hydrolysis, anaerobic metabolism and photolysis (EPA, 2005a; PEIXOTO; TEIXEIRA, 2014; SILVA et al., 2015), posing potential future environmental issues if its extensive usage continues. Moreover, conventional treatment processes applied to urban wastewater plants are very unlikely to remove AMZ and its photolysis products (PEIXOTO; TEIXEIRA, 2014); consequently, the development of alternative remediation techniques capable of degrading this herbicide are needed.

As demonstrated in the previous sections, AOPs can be considered attractive processes for treating AMZ contaminated waters. With exception of the UVA-persulfate activation in the presence of $\mathrm{H}_{2} \mathrm{O}_{2}$, all the processes tested revealed a greater AMZ degradation when a second reactant was added to the medium (i.e. Fe(II), Fe(III) and $\mathrm{Fe}(\mathrm{II})$-complexes). However, in some cases, even when the target pollutant is completely removed, the degradation products can still pose an environmental threat. This was observed with the UV-photolysis degradation products of carbamazepine (DONNER et al., 2013) and chloroacetamines herbicides (SOUISSI et al., 2013), which revealed to be more toxic than the parent-compound. Therefore, it is very important to assess the 
toxicity of the treated effluent prior to its disposal to avoid the exposure of aquatic wildlife to these compounds.

Since toxicity is based on a biological response, different organisms from various taxonomic levels should be used to improve the reliability of results. The organisms normally used in bioassays for toxicity include representative samples of marine, freshwater, or terrestrial ecosystems, such as microorganisms, algae, plants, invertebrates, and fish (TOTHILL; TURNER, 1996). Therefore, the toxicity evaluation of AOPs using bioassays with various organisms can be a useful tool to choose among different processes (RIZZO, 2011).

The most common organisms used for acute ecotoxicity assessment of pesticides solutions treated by AOPs are the standardized tests with daphnias and luminescent bacteria (RIZZO, 2011). However, due to the low concentrations in which pesticides are normally found in water, their effect in organisms is usually not observed in short exposure times; therefore, evaluating their chronic toxicity towards such organisms is also important. For aquatic ecosystems, algal tests are widely used among the most sensitive bioassays for chronic ecotoxicity (RADIX et al., 2000). Yet these are timeconsuming and require a large sample volume. In this regard, Tetrahymena thermophila assay is a good option since it is a short chronic test (24 h), it is simple to implement, and requires only a small quantity of reagents and samples. $T$. thermophila is a nonpathogenic and free-living ciliate protozoan ubiquitously distributed in the natural world. It represents an important trophic level and its presence may indicate healthy aquatic environments (GERHARDT; UD-DAULA; SCHRAMM, 2010). Antimicrobial activity can also serve as a complementary bioassay and is commonly applied for water quality monitoring purposes. For example, Escherichia coli presence is one of the most important microbiological parameters used as a fecal indicator (FREITAS et al., 2016).

The aim of this work was to evaluate the acute toxicity, chronic toxicity and antimicrobial activity of AMZ solutions before and after the treatment with different AOP-based techniques explored in our previous investigations: $\mathrm{SO}_{4}{ }^{-}$-driven $\mathrm{AOPs}$, such as UVA-activated persulfate alone or in the presence of $\mathrm{Fe}(\mathrm{II}), \mathrm{Fe}$ (III) or $\mathrm{Fe}$ (III)carboxylate complexes; and ${ }^{\circ} \mathrm{OH}$-driven AOP, such as UVA-irradiated $\mathrm{Fe}(\mathrm{II}), \mathrm{Fe}(\mathrm{III})$ or $\mathrm{Fe}(\mathrm{III})$-carboxylate complexes. To the best of our knowledge, this is the first time the toxicity of AMZ associated with degradation products by AOPs has been evaluated. Moreover, researches where AOPs efficacy is evaluated with complementary toxicity bioassays do not usually consider such a wide range of microorganisms; therefore, we 
believe that this work configures an original and useful contribution.

\subsection{Materials and Methods}

\subsubsection{Chemicals and microorganisms}

Technical (> 95.4\%, w/w) and analytical grade (99.9\%, w/w) samples of AMZ $\left(\mathrm{C}_{10} \mathrm{H}_{19} \mathrm{~N}_{5} \mathrm{O}_{2}\right.$, CAS number 129909-90-6) were obtained from Arysta LifeScience Corp. and used with no further purification. All the aqueous solutions were prepared in deionized water (18.2 M $\Omega \mathrm{cm}$ ) obtained from a Milli-Q Direct-Q system (Millipore). All the other chemicals were of analytical grade.

Antimicrobial assays were performed with E.coli (Gram - negative bacteria ATCC® 23716) and B. subtilis (Gram-positive bacteria, ATCC® 168). These strains were obtained from ATCC (Manassas, USA) and CPQBA (Campinas, Brazil), respectively. V. fischeri strains purchased from Unwelt (Blumenau, Brazil) were used in the Microtox ${ }^{\circledR}$ toxicity assays.

Microalgae $C$. vulgaris was donated by the Botanic Institute of the São Carlos Federal University (Brazil).

The ciliate $T$. thermophila was part of a microbiotest kit (Protoxkit F), purchased from Ambifirst Lda. (Portugal).

\subsubsection{Experimental setup}

Photodegradation experiments were performed as described in previous sections, in an experimental apparatus as illustrated in Figure 5.

At the end of each process, the remaining solution was stored in sterile falcon tubes and kept in the fridge at $0-4{ }^{\circ} \mathrm{C}$ until the day of the ecotoxicity tests (no longer than 30 days).

Different degradation processes already explored in our previous studies were evaluated in the present work in terms of toxicity removal efficiency of AMZ solutions with different ecotoxicity assays. UVA-activated persulfate alone or in the presence of $\mathrm{Fe}(\mathrm{II}), \mathrm{Fe}(\mathrm{III})$ or $\mathrm{Fe}(\mathrm{III})$-carboxylate complexes were carried out at free $\mathrm{pH}$ because, when persulfate is added, the $\mathrm{pH}$ drops to nearly 3 and does not significantly change during the reaction. The initial concentration of reactants was fixed at $2.5 \mathrm{mmol} \mathrm{L}^{-1}$ for 
persulfate (PS) and $0.1 \mathrm{mmol} \mathrm{L}^{-1}$ for $\mathrm{Fe}(\mathrm{II})$ and $\mathrm{Fe}(\mathrm{III})$. Fe(III)-carboxylates complexes were prepared by mixing the solutions of $\mathrm{Fe}_{2}\left(\mathrm{SO}_{4}\right)_{3} .5 \mathrm{H}_{2} \mathrm{O}$ (containing $0.1 \mathrm{mmol} \mathrm{L}^{-1}$ in $\mathrm{Fe}(\mathrm{III}))$ with the corresponding carboxylate $\left(1 \mathrm{mmol} \mathrm{L}^{-1}\right.$ of oxalate, $0.4 \mathrm{mmol} \mathrm{L}^{-1}$ of citrate or $0.1 \mathrm{mmol} \mathrm{L}^{-1}$ of tartrate), in the dark and before adding any other compound to the solution.

The UVA irradiation of $\mathrm{Fe}(\mathrm{II}), \mathrm{Fe}(\mathrm{III})$ or $\mathrm{Fe}(\mathrm{III})$-carboxylates complexes in the absence of persulfate was performed under controlled $\mathrm{pH}$ (around 3) by an automated $\mathrm{pH}$ control system (see APPENDIX E) to avoid iron precipitation, using diluted $\mathrm{HClO}_{4}$ or $\mathrm{NaOH}$ solutions.

\subsubsection{Analytical methods}

UV-vis absorption spectra were measured with a Varian Cary 50 UV-vis spectrophotometer using a 1-cm path-length Suprasil ${ }^{\circledR}$ quartz cuvette, in the range 190$820 \mathrm{~nm}$ and $1 \mathrm{~nm}$ intervals.

Dissolved organic carbon (DOC) determinations were carried out by a TOC-L analyzer (Shimadzu).

AMZ concentration during the degradation experiments was followed by HPLCUV (Shimadzu, Series 20A) using the same column and methodology previously described (see section 4.1.3).

\subsubsection{Ecotoxicity tests}

For ecotoxicity evaluation, samples were collected at initial (0 min), intermediate (60 $\mathrm{min})$ and final degradation times $(120 \mathrm{~min})$ for processes containing $\mathrm{Fe}(\mathrm{III})$ carboxylates, since they proved to be faster in our previous studies, while only initial (0 $\min )$ and final degradation times $(120 \mathrm{~min})$ where collected for the others. Samples were filtered with a sterile PVDF $0.22-\mu \mathrm{m}$ membrane before performing any ecotoxicity test.

Five ecotoxicity tests were selected: $V$. fischeri (acute toxicity), T. thermophila (chronic toxicity), C. vulgaris (chronic toxicity), and antimicrobial activity against Grampositive (B. subtilis) and Gram-negative (E. coli) bacteria. These species were chosen because some tests are standardized and others are commonly used to evaluate the toxicity reduction during the treatment of contaminated waters by AOPs (CAIANELO et 
al., 2016; FREITAS et al., 2016; SAGGIORO et al., 2015; URBANO et al., 2016). For all the assays, serial dilutions of a $414-\mu \mathrm{mol} \mathrm{L}^{-1}\left(100 \mathrm{mg} \mathrm{L}^{-1}\right) \mathrm{AMZ}$ solution were used to find the dose at which $50 \%$ of the population exhibited a loss in their response (luminescence loss or growth inhibition), in order to calculate the $\mathrm{EC}_{50}$ values.

\subsubsection{1- Vibrio fischeri acute toxicity test}

This test is based on the inhibition of luminescence of the marine bacteria $V$. fischeri before and after contacting with the sample. The $V$. fischeri culture was stored at $-10{ }^{\circ} \mathrm{C}$ and reactivated in $1.0 \mathrm{~mL}$ of a reconstitution solution composed of $0.01 \%$ sodium chloride. The $\mathrm{pH}$ value of the samples was adjusted between 6.0 and 8.0 using $\mathrm{NaOH}$ solution. Analyses were carried out in screening mode according with the basic $81.9 \%$ Microtox $^{\circledR}$ test protocol, using a Microtox Model 500 analyzer and MicrotoxOmni v. 4.2 software (Modern Water, Inc.) (see Figure 18). The contact time was $30 \mathrm{~min}$. The evolution of toxicity was expressed in terms of luminescence inhibition percentage (\%), following the established Microtox protocol.

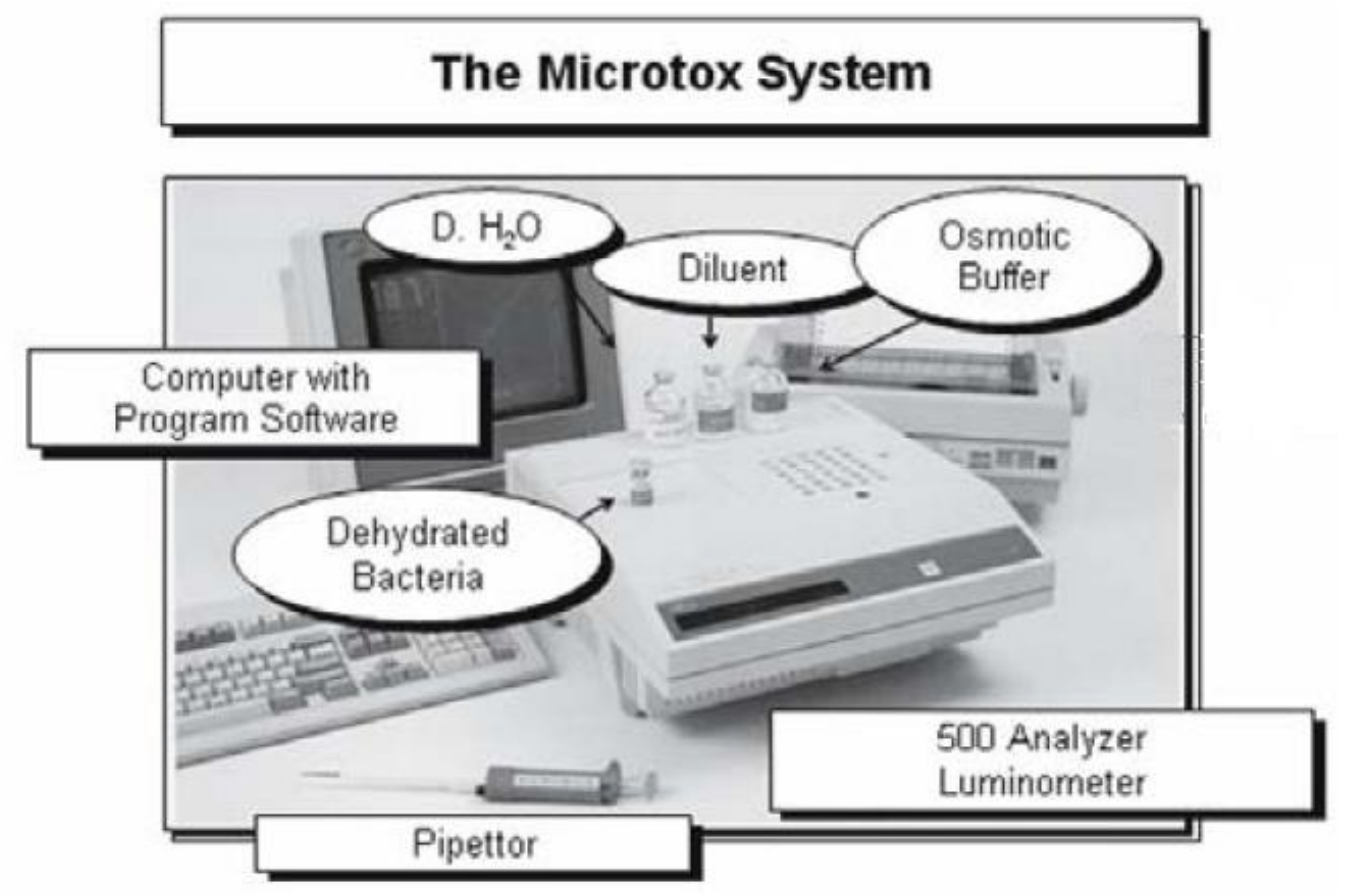

Figure 18. Microtox equipment and suplies (adapted from Microtox ${ }^{\circledR}$ test protocol).

\subsubsection{Tetrahymena thermophila chronic tests}

The 24-h growth inhibition tests with the ciliate $T$. thermophila were performed according to the standard operational procedure of the Protoxkit F (PROTOXKIT, 1998). A picture of this microbiotest kit is shown in Figure 19. The tests were based on the turnover of substrate into ciliate biomass: normal proliferating cell cultures turn the 
substrate suspension clear in $24 \mathrm{~h}$, while inhibited cultures remain turbid. Optical density (OD) measurements of the turbidity quantify the degree of inhibition. Ciliate inoculum was exposed to the samples and the OD at $440 \mathrm{~nm}$ was measured in a spectrophotometer at the beginning $(\mathrm{OD} \mathrm{t})_{0}$ ) and at the end $\left(\mathrm{OD} \mathrm{t}_{24}\right)$ of the test. Deionized water was used as the control. The difference between the mean OD at $t_{0}$ and $t_{24}$ for each sample $(\Delta O D)$ and for the control $\left(\Delta \mathrm{OD}_{\mathrm{C}}\right)$ was calculated. The percent inhibition was calculated by Eq. 28 . All the samples were tested in duplicate.

$\%$ Inhibition $=\left(1-\Delta \mathrm{OD} / \Delta \mathrm{OD}_{\mathrm{C}}\right) \times 100$

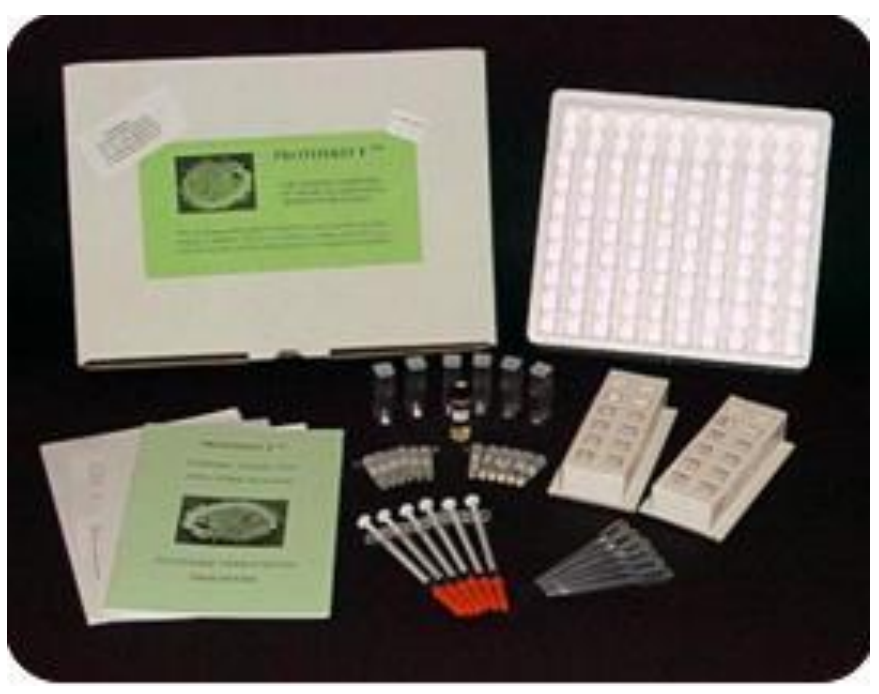

Figure 19. Picture of the Protoxkit $F$ and its contents.

\subsubsection{Chlorella vulgaris chronic tests}

Procedures for culture and tests using $C$. vulgaris followed the Brazilian regulations ABNT-NBR-12648:2011. Before filtering the samples, their $\mathrm{pH}$ values were adjusted between 6.0 and 8.0 by using $\mathrm{NaOH}$ solution $\left(10 \mathrm{mmol} \mathrm{L}^{-1}\right)$ to meet the tolerance range of $C$. vulgaris. Microalgae were cultivated in WC medium (APPENDIX G, Table G1) (ANDERSEN, 2005) and test solutions were prepared by mixing $60 \mathrm{~mL}$ of the sample with $10 \mathrm{~mL}$ of the algal suspension during its exponential growth phase (inoculum containing a microalgae dry mass of $0.088 \pm 0.015 \mathrm{~g} \mathrm{~L}^{-1}$ ). These solutions were stirred under light for $72 \mathrm{~h}$ (see Figure 20). The spectrum of the lamps used in the microalgae culture is shown in Figure 21, with its maximum emission above $400 \mathrm{~nm}$, which is above the wavelength at which PS and Fe(III)-complexes absorb, so no further reaction is expected during this procedure. The OD at $665 \mathrm{~nm}$ was measured at the beginning and at the end of the test. Deionized water was used as the control. Then, the inhibition percentage (\%) was calculated by Eq. 28. 
In chronic tests, a sample was considered toxic when the inhibition (\%) of the test organism was higher than $20 \%$ of the inhibition of the control groups. An increase in microalgae growth higher than $20 \%$ was considered a trophic effect (SAGGIORO et al. 2015).

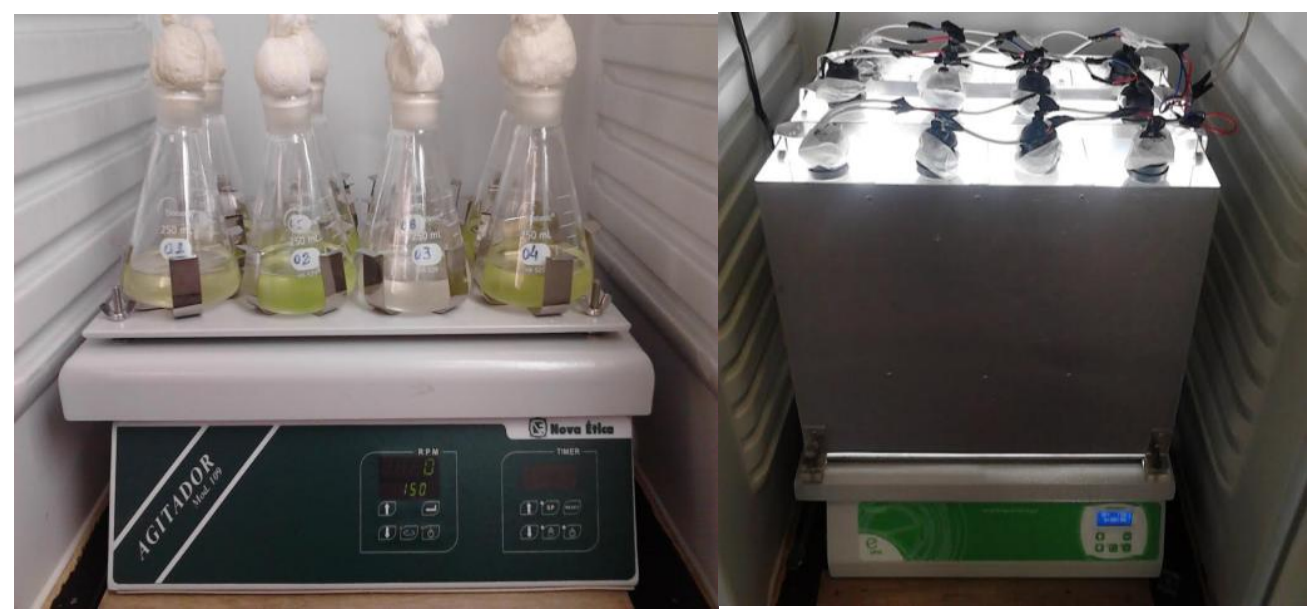

Figure 20. C. vulgaris culture growth system.

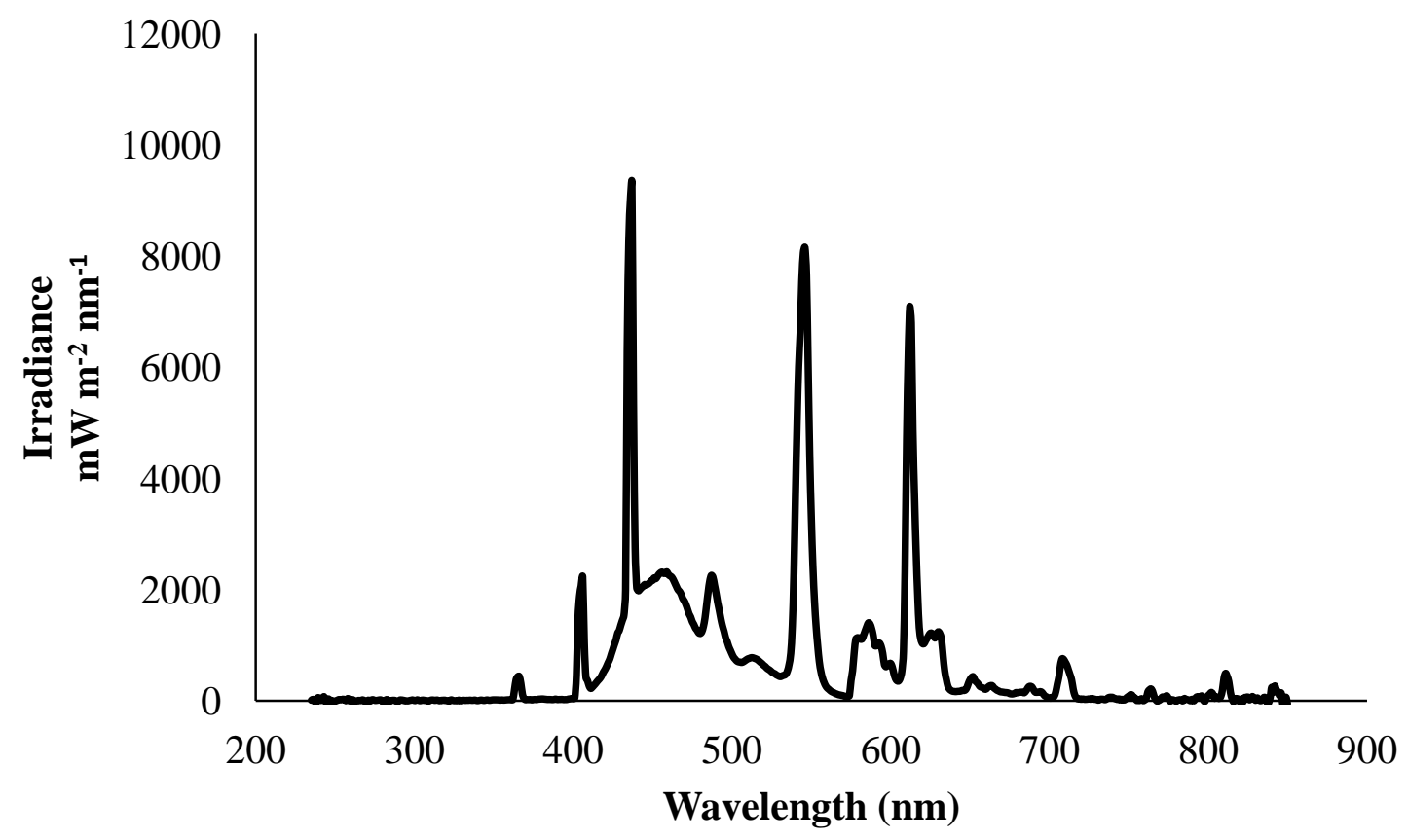

Figure 21. Emission spectrum of the lamps used in the microalgae growth system.

6.1.4.4 Antimicrobial activity against Gram-positive (B. subtilis) and Gramnegative (E. coli) bacteria

Antimicrobial activity assays were performed according to the method described by Caianelo et al. (2016), with some modifications, as the samples were not serially diluted. The antimicrobial activity was evaluated by using the bacteria culture with a 
population density of $1.0 \times 10^{6} \mathrm{CFU} \mathrm{mL} \mathrm{m}^{-1}$.

An aliquot of each sample $(90 \mu \mathrm{L})$ was added into two wells of a 96-well microtiter plate (to have the result in duplicate), and $10 \mu \mathrm{L}$ of $1 \mathrm{mmol} \mathrm{L}^{-1}$ phosphate buffer ( $\mathrm{pH} 8$ ) was added to the sample. Two wells contained only the buffer solution (100 $\mu \mathrm{L}$ ) to verify the bacterial growth in the absence of any sample (controls). After that, all the wells (with samples and the controls) were inoculated with $100 \mu \mathrm{L}$ of the bacteria culture (E. coli or B. subtilis) (Figure 22). The plate was sealed and incubated for $8 \mathrm{~h}$ at $37^{\circ} \mathrm{C}$. After this period, the absorbance of each sample well was measured at $620 \mathrm{~nm}$ by a SpectraMax microplate reader (Molecular Devices). The absorbance measurements were converted to growth inhibition values, as described by Eq. 29.

$I(\%)=\frac{A_{0}-A}{A_{0}} \times 100$

Where $A_{0}$ is the absorbance of the well containing phosphate buffer and $A$ is the absorbance of each sample after $8 \mathrm{~h}$.

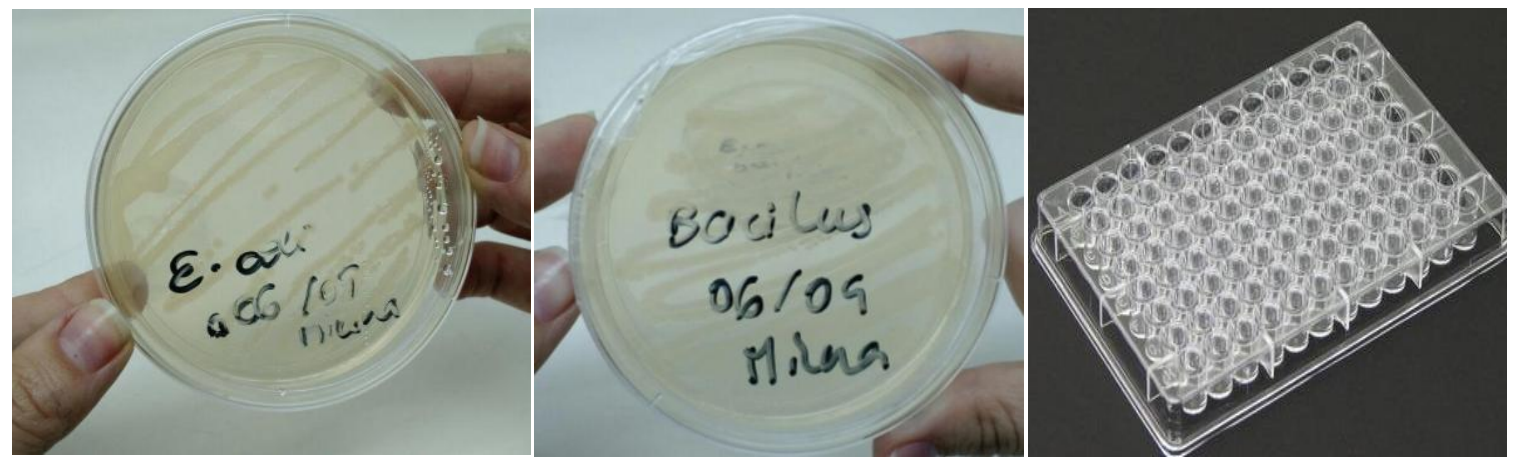

Figure 22. Pictures of E. coli and B. subtilis cultures and microtiter plate where the toxicity tests regarding these bacteria were performed.

\subsection{Results and Discussion}

\subsubsection{AMZ removal by ${ }^{\bullet} \mathrm{OH}$-driven and $\mathrm{SO}_{4}{ }^{-}-$-driven $\mathrm{AOPs}$}

Our previous investigation focused on evaluating the efficiency of UVApersulfate activated processes on AMZ degradation, in terms of the observed degradation rate constant $\left(k_{\mathrm{obs}}\right)$. The effect of a second reactant, such as $\mathrm{Fe}(\mathrm{II}), \mathrm{Fe}$ (III) and $\mathrm{Fe}$ (III)carboxylates was also evaluated and proved to enhance the degradation efficiency (higher $k_{\text {obs }}$ ), especially when Fe(III)-carboxylates were added. This observation was attributed to a synergistic effect between the activation of persulfate (PS) by UVA radiation, which produces $\mathrm{SO}_{4}{ }^{*-}$ radicals, the $\mathrm{Fe}(\mathrm{III})$ to $\mathrm{Fe}(\mathrm{II}) \mathrm{UVA}-$ recycling, and the photolysis of $\mathrm{Fe}(\mathrm{III})$-complexes, which produces ${ }^{\circ} \mathrm{OH}$ radicals. Furthermore, the contribution of UVAirradiated $\mathrm{Fe}(\mathrm{II}), \mathrm{Fe}(\mathrm{III})$ and $\mathrm{Fe}(\mathrm{III})$-carboxylates on AMZ degradation, in the absence of 
persulfate, was also studied and, despite the lower degradation rates observed, proved to be efficient for the herbicide removal. Fe(II) in aqueous solutions in the presence of UV radiation is known to give $\mathrm{Fe}(\mathrm{III})$ and $\mathrm{H}_{2}$ (BRATERMAN et al., 1984). In turn, at a $\mathrm{pH}$ near 3, this $\mathrm{Fe}(\mathrm{III})$ produces ${ }^{\circ} \mathrm{OH}$ radicals when irradiated (CIEŚLA et al., 2004), which are responsible for $\mathrm{AMZ}$ degradation. In the presence of organic ligands, such as carboxylates, there is another photochemical mechanism: the Fe(III)-carboxylate irradiation leads to the formation of $\mathrm{Fe}(\mathrm{II})$ and $\mathrm{H}_{2} \mathrm{O}_{2}$, therefore giving rise to the Fenton reaction and, consequently, to the formation of ${ }^{\circ} \mathrm{OH}$ radicals.

Table 13 compares AMZ percent removals obtained by the ${ }^{\circ} \mathrm{OH}$-driven and $\mathrm{SO}_{4}{ }^{\circ}-$ driven processes. Analyses revealed high removal efficiencies (> 70\%) after 120 minutes in all cases. As expected, the AMZ removal increases as the irradiation time increases. However, no significant TOC removal was observed in any of the processes studied, revealing that none of them was capable of mineralizing AMZ, which confirms its persistent character for both AMZ and degradation products. These results corroborate those published by Peixoto and Teixeira (2014), who also obtained no significant TOC removal even when complete AMZ removal by photolysis was achieved.

Table 13. AMZ percent removals after the ${ }^{\circ} \mathrm{OH}$ - driven and $\mathrm{SO}^{\circ}{ }^{\circ}$-driven AOPs.

\begin{tabular}{|c|c|c|c|}
\hline & \multicolumn{3}{|c|}{ AMZ removal (\%) } \\
\hline & \multirow[t]{2}{*}{ Degradation process } & \multicolumn{2}{|c|}{ Irradiation time (min) } \\
\hline & & 60 & 120 \\
\hline \multirow{5}{*}{$\cdot \mathrm{OH}$-driven AOPs } & $\mathrm{Fe}(\mathrm{II})+\mathrm{UVA}$ & - & 79.4 \\
\hline & $\mathrm{Fe}(\mathrm{III})+\mathrm{UVA}$ & - & 79.1 \\
\hline & $\mathrm{Fe}(\mathrm{III})$-oxalate + UVA & 65.1 & 91.2 \\
\hline & $\mathrm{Fe}(\mathrm{III})$-citrate + UVA & 34.6 & 78.9 \\
\hline & $\mathrm{Fe}(\mathrm{III})$-tartrate + UVA & 29.0 & 75.8 \\
\hline \multirow{6}{*}{$\mathrm{SO}_{4}{ }^{-}$-driven $\mathrm{AOPs}$} & PS + UVA & - & 89.9 \\
\hline & $\mathrm{PS}+\mathrm{Fe}(\mathrm{II})+\mathrm{UVA}$ & - & $>92.5$ (N.D.) \\
\hline & PS+Fe(III)+UVA & - & 90.0 \\
\hline & $\mathrm{PS}+\mathrm{Fe}(\mathrm{III})$-oxalate + UVA & $>92.5$ (N.D) & $>92.5$ (N.D.) \\
\hline & $\mathrm{PS}+\mathrm{Fe}(\mathrm{III})$-citrate + UVA & $>92.5$ (N.D) & $>92.5$ (N.D.) \\
\hline & $\mathrm{PS}+\mathrm{Fe}(\mathrm{III})$-tartrate + UVA & $>92.5$ (N.D) & $>92.5$ (N.D.) \\
\hline
\end{tabular}

N.D. = not detectable, since the concentration is below the HPLC quantification limit. 
Given the persistence of the degradation products, even after 120 minutes of irradiation, toxicity assessment is required, since treated solutions can still pose an environmental threat.

\subsubsection{Ecotoxicity assessment}

To evaluate the effectiveness of a water treatment process, it is important to assess not only the pollutant removal but also the remaining toxicity after treatment. In fact, in some circumstances, the applied treatment technique can produce more toxic compounds than the parent compounds (DONNER et al., 2013; SOUISSI et al., 2013). In this study, the toxicity of AMZ solutions before and after the processes discussed in previous sections was evaluated. For that purpose, five organisms (three species of bacteria, one microalgae and one protozoan) representing different trophic levels (decomposers, a primary producer and a filter feeder) were tested in chronic, acute and antimicrobial activity ecotoxicity assays.

Regarding acute toxicity, the initial solution containing $41.4 \mu \mathrm{mol} \mathrm{L}{ }^{-1}$ AMZ did not cause any inhibitory effect on $V$. fischeri within 30 min of contact nor did a 10-fold higher concentrated solution. This means that $V$. fischeri is very resistant to AMZ and it would be necessary to test higher $\mathrm{AMZ}$ concentrations to be able to obtain the $\mathrm{EC}_{50}$ value. Since the environmental concentrations of $A M Z$ are detected at much lower levels (SANTOS; CORREIA, 2015), this herbicide is currently very unlikely to pose any threat to $V$. fischeri.

In order to perform the oxidation process, some reactants were added prior to irradiation, which, in some cases, enhanced the inhibition of the bacteria luminescence when in contact with the initial AMZ solution into toxic levels (\% Inhibition > 20\%). This effect was observed when PS, Fe(II), Fe(III), PS +Fe(III), Fe(III)-oxalate complex, $\mathrm{PS}+\mathrm{Fe}(\mathrm{III})$-oxalate complex, PS + Fe(III)-citrate complex, Fe(III)-tartrate complex and $\mathrm{PS}+\mathrm{Fe}$ (III)-tartrate complex were added (Figure 23). It is worth mentioning that PS alone did not cause any inhibitory effect on these bacteria either. After irradiation, some of these processes generated even more toxic degradation products, as well as some of those samples that initially did not cause inhibitory effects revealed some toxicity after irradiation. 


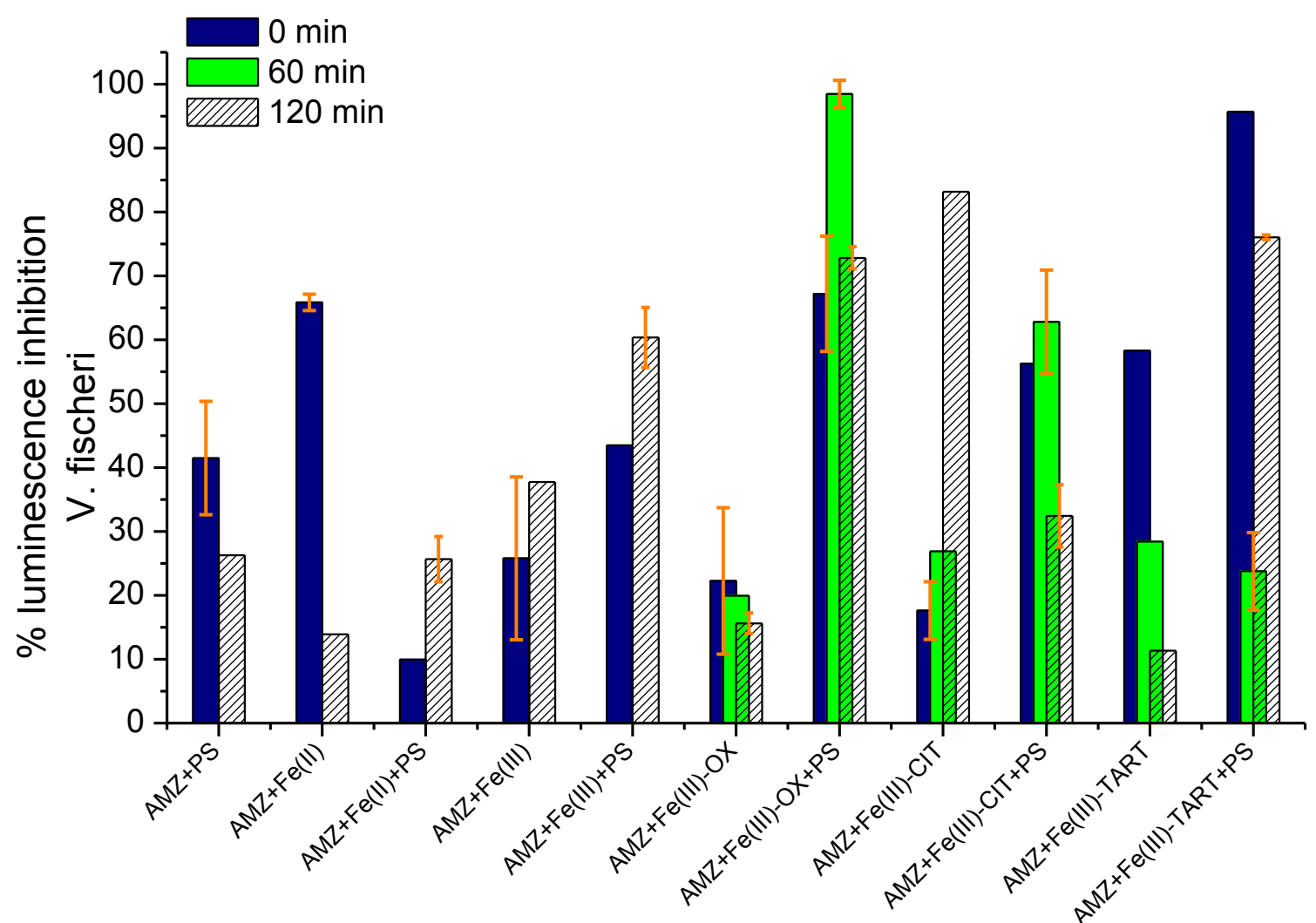

Figure 23. Acute toxicity evaluation of an AMZ solution before (navy bar, time 0 min) and after (green bar, time $60 \mathrm{~min}$; stripped bar, time $120 \mathrm{~min}$ ) different AOPs, towards V. fischeri. Fe(III)-OX: Fe(III)-oxalate complex; Fe(III)-CIT: Fe(III)-citrate complex; Fe(III)-TART: Fe(III)-tartrate complex.

The cases in which the degradation process led to more toxic compounds than the parent untreated AMZ solutions are mostly related to fast AMZ removals. Since no AMZ mineralization was observed at the end of any of the processes applied, the final AMZ degradation products are probably low molar mass organic compounds, such as organic acids, aldehydes and ketones, which are known to be toxic to $V$. fischeri (DANTAS et al., 2008; TROVÓ et al., 2009; WANG et al., 2016).

In a previous study, in which AMZ photolysis products were identified, the degradation products also proved to be resistant to mineralization, with a nonbiodegradable character (PEIXOTO; TEIXEIRA, 2014). Although a photolytic process was also applied herein to degrade AMZ, auxiliary reactants were used (PS and iron) to enhance AMZ degradation; therefore, our experiments may have resulted in different degradation pathways, as well as in different photoproducts, in comparison to those reported by Peixoto and Teixeira (2014), which prevents comparing the toxicity of our degradation products to those identified in their study.

Regarding chronic toxicity, the initial AMZ solution containing $41.4 \mu \mathrm{mol} \mathrm{L}^{-1}(10$ $\mathrm{mg} \mathrm{L}^{-1}$ ) revealed to be very toxic to the microalgae C. vulgaris, inhibiting $87.1 \pm 12.5 \%$ 
of its growth after $72 \mathrm{~h}$. The $\mathrm{EC}_{50}(72-\mathrm{h})$ of $\mathrm{AMZ}$ calculated for this organism was 1.16 $\mathrm{mg} \mathrm{L}^{-1}\left(4.8 \mu \mathrm{mol} \mathrm{L} \mathrm{L}^{-1}\right)$, which is a little higher than that reported for other herbicides exposed to $C$. vulgaris (diuron and prometryn) along the same period (BURNS; RITCHIE; KENNEDY, 2014). Nevertheless, according to Persoone et al. (2000), if the $\mathrm{EC}_{50}(72 \mathrm{~h})$ for $C$. vulgaris is between 1 and $10 \mathrm{mg} \mathrm{L}^{-1}$, the contaminant is considered harmful. This relatively high sensitivity of $C$. vulgaris to AMZ was expected, since herbicides mode-of-action include the disruption of some vital processes of photosynthetic organisms, among which microalgae are included.

In some cases, the addition of reactants to the initial AMZ solution enhanced microalgae growth inhibition greater than $100 \%$, meaning that the reactants not only inhibited the growth, but also killed some microalgae. This effect was more evident when $\mathrm{Fe}(\mathrm{III})$-oxalate, PS + Fe(III)-oxalate and PS + Fe(III)-tartrate were added (Figure 24). However, similarly to $V$. fischeri, this microalgae did not show any sensitivity to persulfate alone. For processes in which a high AMZ removal ( $\geq 90 \%)$ was achieved, not only the toxicity was removed, but also the formation of degradation products that stimulated microalgae growth (trophic effect) was observed. Only for the Fe(III)-oxalate + PS this cannot be assumed since, after irradiation, the inhibition is within the normal variation expected for such tests $(<20 \%$ variation of growth). This means that, probably, the same AMZ final degradation products which were toxic to $V$. fischeri bacteria act as micronutrients to $C$. vulgaris.

Among the processes which stimulated microalgae growth (Fe(II) + PS; Fe(III)oxalate; Fe(III)-citrate + PS; Fe(III)-tartrate + PS), only for the Fe(III)-oxalate photolysis the irradiation time reduced the trophic effect of the degradation products. However, longer irradiations would be necessary to evaluate this tendency. A study developed by Saggioro et al. (2015), where indigo carmine dye was degraded by photocatalytic processes, also reported degradation products with trophic effect on microalgae (Pseudokirchneriella subcapitata). 


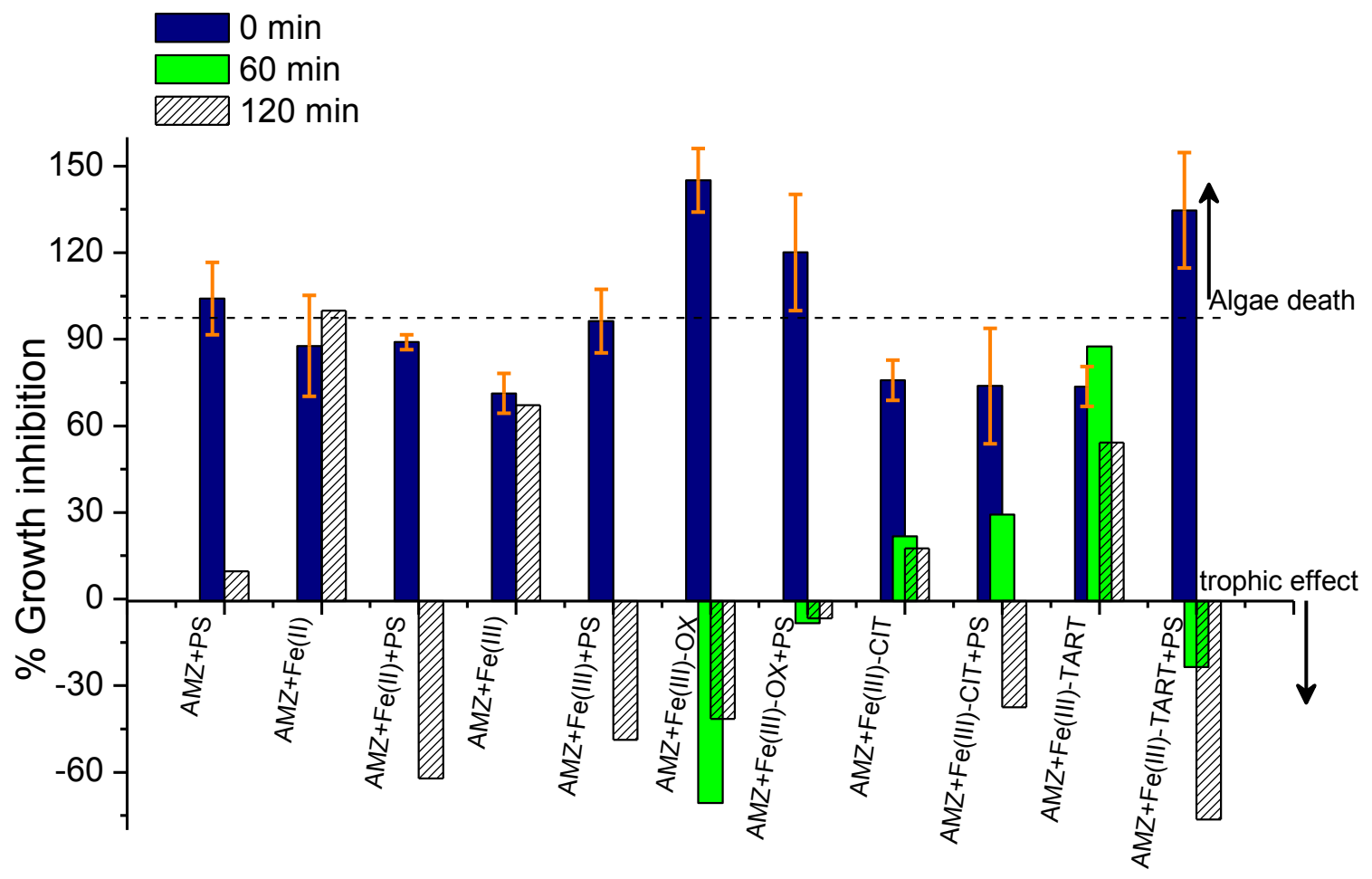

Figure 24. Chronic toxicity evaluation of an AMZ solution before (navy bar, time $0 \mathrm{~min}$ ) and after (green bar, time $60 \mathrm{~min}$; stripped bar, time $120 \mathrm{~min}$ ) different AOPs, to C. vulgaris microalgae. Algae death is observed when growth inhibition>100\%, while trophic effect is observed when growth inhibition < $0 \%$. Fe(III)-OX: Fe(III)-oxalate complex; Fe(III)-CIT: Fe(III)-citrate complex; Fe(III)-TART: Fe(III)-tartrate complex.

For the chronic ecotoxicity assay with the protozoan $T$. thermophila, a $24 \mathrm{~h} \mathrm{EC}_{50}$ of $411 \mu \mathrm{mol} \mathrm{L} \mathrm{L}^{-1}\left(99.3 \mathrm{mg} \mathrm{L}^{-1}\right)$ was found for AMZ. Although the initial AMZ solution containing $41.4 \mu \mathrm{mol} \mathrm{L} \mathrm{L}^{-1}$ did not inhibit this organism, the addition of reactants substantially enhanced the solutions toxicity, except when Fe(II) was added (Figure 25). After irradiation, only three processes promoted significant toxicity reductions (PS + UVA; Fe(II) + UVA and Fe(II) + PS + UVA), while the other revealed to be extremely toxic to the protozoan. Control experiments, in which each reactant was tested against this organism, indicated that persulfate is the most toxic reactant of all and, even after irradiation, its toxic effect towards T. thermophila remained. In fact, our previous studies, in which measurements of PS were made during UVA irradiation, showed that this reactant is not significantly consumed, explaining the toxicity persistence. Actually, the PS toxic effect can mask the degradation products toxicity, then disabling any possible evaluation about their own effect on T. thermophila. If this toxicity assay had been performed separately from the others, we would have concluded that only the photooxidation of $\mathrm{Fe}(\mathrm{II})$ achieved a good response. Despite the scarcity of literature 
reporting the use of $T$. thermophila to evaluate effluents toxicity, previous studies indicated that the sensitivity of this organism is comparable with other standard organisms commonly used to perform similar toxicity tests, such as microalgae and daphnids (FREITAS et al., 2016). However, comparing our results obtained from using the $C$. vulgaris assay with those using the protozoan assay, the latter is evidently much more sensitive to the added reactants than the former and different conclusions are achieved from each assay. Nevertheless, comparing the toxicity based on the $\mathrm{EC}_{50}$ value for each organism against $\mathrm{AMZ}$, it is possible to conclude that the microalgae is the most sensitive organism to the herbicide.

This is an interesting finding since an ecotoxicity assay performed alone could have led to misleading conclusions. Different organisms living in the same waterbody reveal different behaviors towards the same chemical or mixture of chemicals, making it important to study their effect upon those organisms prior to disposal.

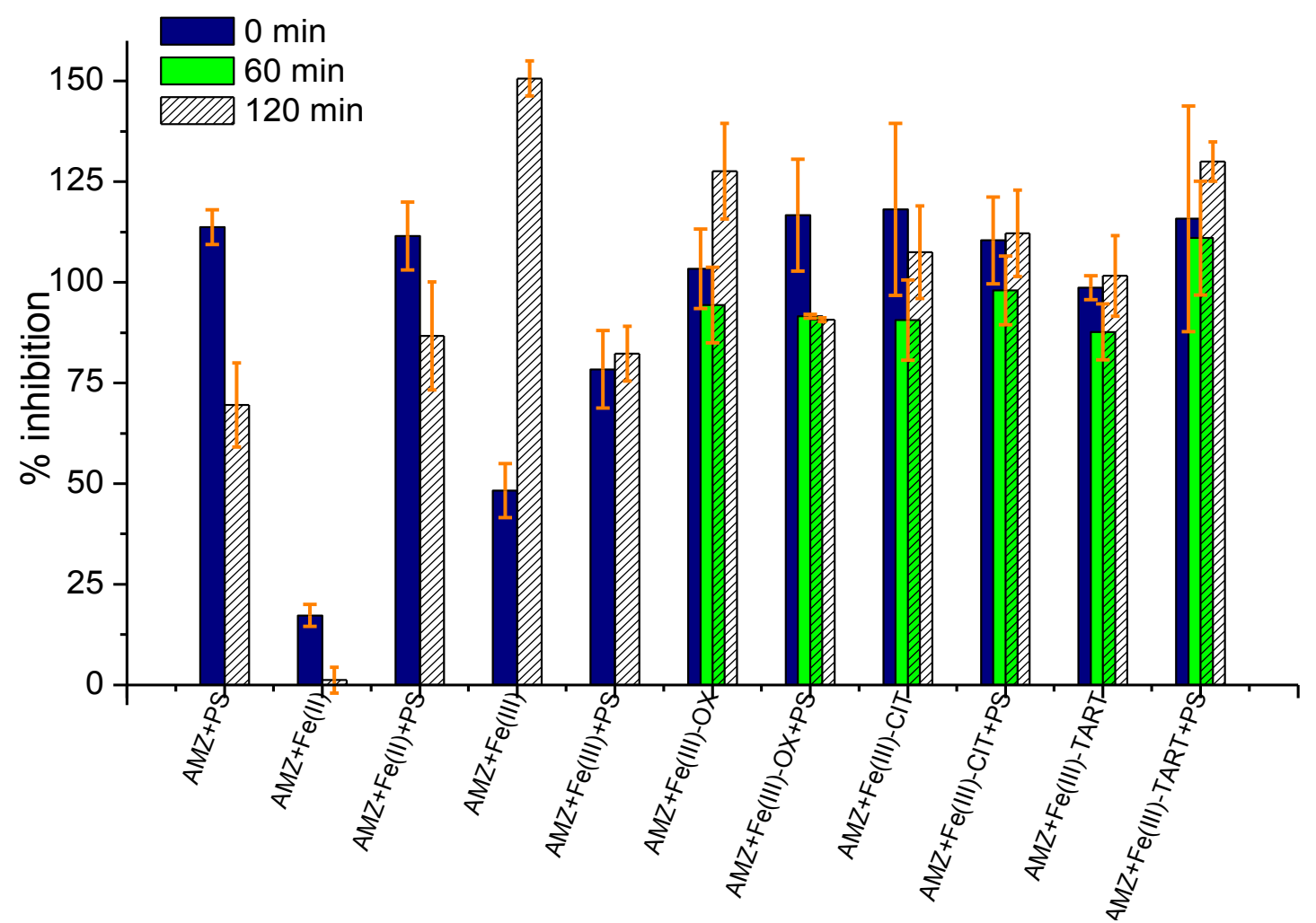

Figure 25. Chronic toxicity evaluation of an AMZ solution before (navy bar, time 0 min) and after (green bar, time $60 \mathrm{~min}$; stripped bar, time $120 \mathrm{~min}$ ) different AOPs, towards T. termophila. Fe(III)-OX: Fe(III)oxalate complex; Fe(III)-CIT: Fe(III)-citrate complex; Fe(III)-TART: Fe(III)-tartrate complex.

To evaluate the residual antimicrobial activity of AMZ solutions before and after the processes, Gram positive (B. subtilis) and Gram negative (E. coli) microorganisms were used. Both the initial AMZ solution, with a concentration of $41.4 \mu \mathrm{mol} \mathrm{L}^{-1}(10 \mathrm{mg}$ $\left.\mathrm{L}^{-1}\right)$, and a 10-fold higher concentrated $\left(414 \mu \mathrm{mol} \mathrm{L^{-1 }}, 100 \mathrm{mg} \mathrm{L}^{-1}\right)$ did not significantly 
inhibit the growth of these organisms (growth inhibition $<20 \%$ ), meaning that these bacteria have low sensitivity to this pesticide and extremely high amounts of the latter are needed to achieve the $\mathrm{EC}_{50}$ value. However, the addition of reactants to the initial AMZ solution affected the growth of B. subtilis (Figure 26), while E. coli remained unaffected. This resistance of E.coli was already observed in a study developed by Handore et al. (2015), in which this organism was the only bacteria growing in the presence of several pesticides. No inhibition was observed in both bacteria when each reactant was tested alone, meaning that the increase of toxicity observed for the gram positive bacteria is a result of the mixture $\mathrm{AMZ}+$ reactants.

In general, all the processes resulted in solutions with higher toxicity towards $B$. subtilis in comparison with the AMZ initial solution, excepting the degradation processes based on the photooxidation of $\mathrm{Fe}(\mathrm{II})$ and photolysis of the $\mathrm{Fe}$ (III)-oxalate complex. These conclusions are similar to those obtained for $V$.fischeri. It is worth emphasizing that these organisms belong to the same trophic level (decomposers), although the latter revealed higher sensitivity to the pesticide and its degradation products. Nevertheless, all the bacteria tested revealed high resistance to AMZ, but different responses were achieved from each one when the pesticide was submitted to equal degradation processes. This result reinforces the importance of evaluating the toxicity towards different microorganisms, even those from the same trophic level. 


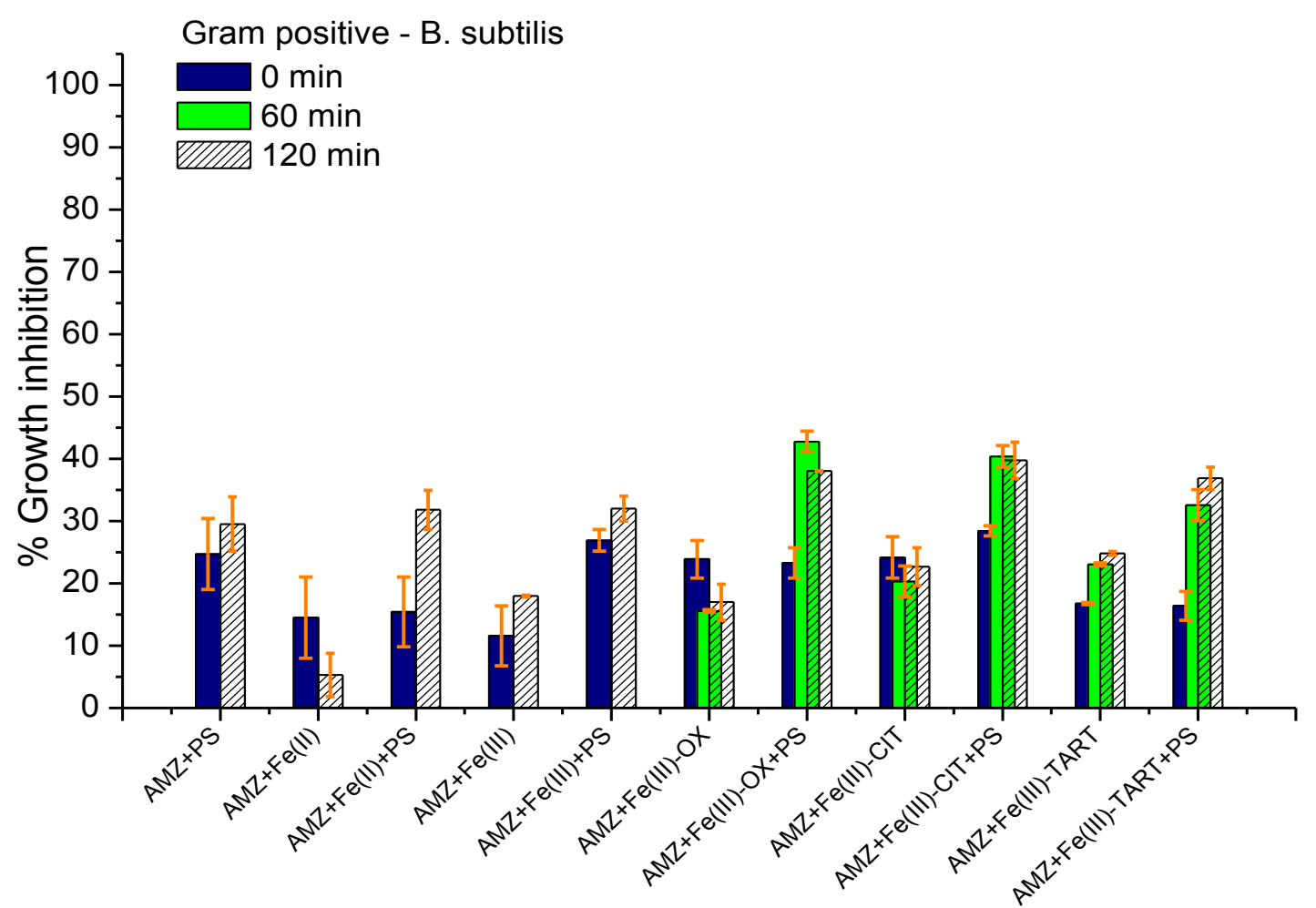

Figure 26. Antimicrobial activity evaluation of an AMZ solution before (navy bar, time 0 min) and after (green bar, time $60 \mathrm{~min}$; stripped bar, time $120 \mathrm{~min}$ ) different AOPs, towards B. subtilis. Fe(III)-OX: Fe(III)-oxalate complex; Fe(III)-CIT: Fe(III)-citrate complex; Fe(III)-TART: Fe(III)-tartrate complex.

\subsection{Partial Conclusions}

Processes in which the highest AMZ removal was achieved, i.e, UVA + PS + $\mathrm{Fe}(\mathrm{II}), \mathrm{UVA}+\mathrm{PS}+\mathrm{Fe}(\mathrm{III})$-oxalate, $\mathrm{UVA}+\mathrm{PS}+\mathrm{Fe}(\mathrm{III})$-citrate and UVA + PS + Fe(III)tartrate, derived persistent degradation products that revealed to be more toxic than the parent-pollutant towards $V$. fischeri, T. termophila and B. subtilis. Regarding the microalgae bioassay, the same processes resulted in the opposite effect: instead of inhibiting, they stimulated the algae growth (trophic effect), which is also an undesirable effect. E. coli revealed extreme resistance to AMZ, preventing the toxicity of the solutions from being assessed based on that assay. This result highlights the fact that an ecotoxicity assay performed alone could have led to misleading conclusions.

Different organisms living in the same waterbody reveal different behaviours towards the same chemical or mixture of chemicals, reinforcing the importance of studying their effect upon those organisms prior to disposal. Nonetheless, based on the organism sensitivity observed in our results, we recommend that algae bioassays be performed when assessing the ecotoxicity of an effluent with a significant presence of herbicides. In sum, processes that generally reduced AMZ concentration to non-toxic levels, without producing more toxic compounds, such as PS + UVA and Fe(II) + UVA, seem to be preferable to those which removed AMZ completely. 


\section{AMICARBAZONE DEGRADATION PROMOTED BY ZVI-ACTIVATED PERSULFATE: STUDY OF RELEVANT VARIABLES FOR PRACTICAL APPLICATION}

Fenton and Fenton-like processes, which are based on the reaction between a source of iron and a strong oxidant (e.g. $\mathrm{H}_{2} \mathrm{O}_{2}$ ), are among the most studied AOPs (BABUPONNUSAMI; MUTHUKUMAR, 2014), and have proved to successfully degrade a large range of organic pollutants, such as pharmaceuticals (TROVÓ et al., 2009, 2011), hormones (XU et al., 2009), pesticides (MA; SUNG, 2010; MACKUL'AK; PROUSEK; ŠVORC, 2011), dyes (SOHRABI et al., 2014), among others. Similar to the Fenton process, iron as ferrous ion $\left(\mathrm{Fe}^{2+}\right)$ has been the most employed metal in PS activation (Eq. 9) because of its high abundance, low-cost and non-toxic properties. Therefore, this technique can be considered a Fenton-like process.

However, when $\mathrm{Fe}^{2+}$ is oxidized to $\mathrm{Fe}^{3+}$ the PS activation is halted, so large amounts of $\mathrm{Fe}^{2+}$ are required to compensate this effect, hence consisting in a disadvantage of this process. This could also represent another drawback, since too much $\mathrm{Fe}^{2+}$ can scavenge sulfate radicals (Eq. 30), leading to a decline in the process efficiency (HAN et al., 2015).

$\mathrm{Fe}^{2+}+\mathrm{SO}_{4}^{\cdot-} \rightarrow \mathrm{Fe}^{3+}+\mathrm{SO}_{4}^{2-}$

For these reasons, alternative sources of $\mathrm{Fe}^{2+}$ such as UVA irradiated magnetite (AVETTA et al., 2015) and Fe(III)-complexes (GRAÇA; VELOSA; TEIXEIRA, 2017) have been explored for a more efficient PS activation by means of $\mathrm{Fe}^{2+}$ recycling. In the absence of light, zero-valent iron (ZVI) can also be used as an alternative way to induce PS activation by gradually releasing of $\mathrm{Fe}^{2+}$ in water (Eqs. 10-11), that enables PS activation for extended periods (DENG et al., 2014) or by reacting directly in the surface of ZVI particles (Eq. 31) (WENG; TAO, 2015).

$\mathrm{S}_{2} \mathrm{O}_{8}^{2-}+\mathrm{Fe}^{0}(\mathrm{~s}) \rightarrow \mathrm{Fe}^{2+}+2 \mathrm{SO}_{4}^{--}+2 \mathrm{e}^{-}$

ZVI has already shown to be more effective than $\mathrm{Fe}^{2+}$ or $\mathrm{Fe}^{3+}$ in PS activation for a wider range of $\mathrm{pH}$ (DENG et al., 2014), being, therefore, more suitable for environmental applications. Following that, in this study we evaluated the effectiveness of a ZVI-activated persulfate system in the degradation of an emerging pollutant: the 
herbicide amicarbazone (AMZ). As already mentioned, this is a particularly interesting contaminant to study due to the existence of few records in the literature regarding its degradation by different AOP technologies. Given that, our present research intents to contribute to the development of alternative techniques capable of degrading such contaminant. Moreover, in this study, the effect of ZVI size and source, PS and ZVI initial dosage, $\mathrm{pH}$, UVA radiation and inorganic ions are explored together for the first time, hence consisting in an original contribution to the AOP state-of-the-art. These variables were investigated since they enable to infer about the possibility of applying this process under environmental conditions.

\subsection{Materials and Methods}

\subsubsection{Chemicals}

Technical (> 95.4\% w/w) and analytical grade $(99.9 \% \mathrm{w} / \mathrm{w})$ samples of amicarbazone were obtained from Arysta LifeScience Corp. and used with no further purification. All the aqueous solutions were prepared in deionized water $(18.2 \mathrm{M} \Omega \mathrm{cm})$, obtained from a Milli-Q Direct-Q system (Millipore). To test the influence of inorganic ions, samples of bottled mineral water (Baviera São Lourenço) were used as acquired and had the following composition, as described in the bottle label: $\mathrm{HCO}_{3}{ }^{-}, 42.82 \mathrm{mg} \mathrm{L}{ }^{-1}$; $\mathrm{Sr}^{2+}, 0.088 \mathrm{mg} \mathrm{L}^{-1} ; \mathrm{Ca}^{2+}, 1.960 \mathrm{mg} \mathrm{L}{ }^{-1} ; \mathrm{Mg}^{2+}, 2.909 \mathrm{mg} \mathrm{L}{ }^{-1}, \mathrm{~K}^{+}, 2.909 \mathrm{mg} \mathrm{L}{ }^{-1} ; \mathrm{Na}^{+}$, $11.500 \mathrm{mg} \mathrm{L}^{-1}, \mathrm{PO}_{4}{ }^{3-}, 0.11 \mathrm{mg} \mathrm{L}^{-1} ; \mathrm{NO}_{3}{ }^{-}, 0.80 \mathrm{mg} \mathrm{L}^{-1} ; \mathrm{Cl}^{-}, 1.95 \mathrm{mg} \mathrm{L}^{-1} ; \mathrm{SO}_{4}{ }^{2-}, 6.06 \mathrm{mg} \mathrm{L}^{-}$ ${ }^{1}$; F', $0.22 \mathrm{mg} \mathrm{L}^{-1}$; $\mathrm{Br}^{-}, 0.03 \mathrm{mg} \mathrm{L} \mathrm{L}^{-1}$; $\mathrm{pH} 7.03$.

Commercial nano-scale ZVI particles (NANOFER 25) were obtained from NANO IRON (Czech Republic) and used as received. According to the information provided by the manufacturer these particles have a surface area of $20-25 \mathrm{~m}^{2} \mathrm{~g}^{-1}$ and an average size of $50 \mathrm{~nm}$. Other ZVI nanoparticles were prepared by the reduction of ferrous iron using sodium borohydride (98\% purity), according to the procedure of Ponder et al. (2000). After synthesis, the nanoparticles were stored refrigerated in nitrogen-saturated water slurry $(5 \% \mathrm{w} / \mathrm{v})$ for at most one week. The sizes of individual particles were determined by Field Emission Gun-Scanning Electron Microscopy analysis (FEG-SEM), using a FEI Quanta 400 model.

Micro-scale ZVI particles were from J. T. Baker (U.S.A). The surface area of these particles was $3.092 \mathrm{~m}^{2} \mathrm{~g}^{-1}$ (determined by $\mathrm{N}_{2}$ adsorption using a Micromeritics ASAP 2020 surface analyzer). All the other chemicals were of analytical grade. 


\subsubsection{Experimental procedures}

All the experiments were carried out in duplicate in a $250-\mathrm{mL}$ capacity beaker inside a closed container, to avoid the influence of external light. The solution was kept under magnetic stirring to provide a constant mixing state. The reaction temperature was kept under $20{ }^{\circ} \mathrm{C}$ using a cool water bath to ensure that persulfate was not activated by heat. Firstly, the desired amount of ZVI was added into a $100-\mathrm{mL}$ solution containing $41.4 \mu \mathrm{mol} \mathrm{L}{ }^{-1}$ of AMZ. Then, PS was introduced to start the oxidation reaction. Sample aliquots $(0.45 \mathrm{~mL})$ were taken at specified times, immediately filtered through $0.22-\mu \mathrm{m}$ PVDF membranes to separate the ZVI particles from the reaction solution and mixed with $500 \mu \mathrm{L}$ of $\mathrm{MeOH}$ to stop the reaction (VELOSA, NASCIMENTO, 2017). In pHcontrolled experiments the $\mathrm{pH}$ was adjusted with $\mathrm{NaOH}$ or $\mathrm{HClO}_{4}$ solutions. In UVAirradiated experiments the beaker containing the reaction solution was placed under four 15-W blacklight lamps (Sylvania F15W/350 BL T8) positioned at $27 \mathrm{~cm}$ from the liquid surface inside the beaker (Figure 5) and emitting $23.3 \mathrm{~W} \mathrm{~m}^{-2}$ in the wavelength range of 315-400 nm, as determined using a spectroradiometer (SPR 4002, Luzchem). The set was placed inside a closed box. To study the influence of dissolved oxygen a stream of $\mathrm{O}_{2}$ or $\mathrm{N}_{2}$ was bubbled into the solution.

\subsubsection{Analytical methods}

Dissolved Fe(II) concentration was determined according to the o-phenantroline standardized procedure (MORTATTI et al., 1982), as described in section 4.1.3.

AMZ concentration during the degradation experiments was followed by HPLCUV (Shimadzu, Series 20A) using the same column and methodology previously described (see section 4.1.3).

\subsection{Results and Discussion}

\subsection{1 nZVI characterization}

The FEG-SEM analyses (presented in the next section, Figure 35A) reveal that synthesized nZVI particles are spherical with diameters ranging from 103 to $582 \mathrm{~nm}$ (average $180 \mathrm{~nm}$ ), and some aggregates larger than $1 \mu \mathrm{m}$, which is in accordance with previous studies where nZVI were synthesised by similar methods (CORREIA DE VELOSA; PUPO NOGUEIRA, 2013). 


\subsubsection{Influence of ZVI source and size}

The influence of ZVI source and size on AMZ (41.4 $\left.\mu \mathrm{mol} \mathrm{L} \mathrm{L}^{-1}\right)$ degradation by PS/ZVI $\left(1: 1 \mathrm{mmol} \mathrm{L}^{-1}\right)$ is illustrated in Figure 27A. Control experiments in the presence of either ZVI or PS alone were carried out varying the concentration of each reactant and no significant AMZ degradation was observed during $24 \mathrm{~h}$, confirming that none of these reactants alone is responsible for the degradation observed over the reaction time (180 min maximum). As observed in Figure 27, when PS and ZVI are mixed together they promote AMZ degradation, although promoting distinct degradation profiles: nano-sized particles promoted a two-stage degradation, characterized by a faster phase when PS and nZVI are mixed, followed by a stagnation phase, while micro-sized ZVI promoted a gradual degradation over time. This happens since the system reveals a lower $\mathrm{pH}$ during the first moments of reaction (between 3-3.5), leading to a faster $\mathrm{Fe}(\mathrm{II})$ release from ZVI particles (Eq. 32), immediately producing sulfate radicals (Eq. 9) and leading to instantaneous AMZ abatement.

$\mathrm{Fe}^{0}+2 \mathrm{H}^{+} \rightarrow \mathrm{Fe}^{2+}+\mathrm{H}_{2}$

As observed in Figure 27B, a high amount of Fe(II) is released from nano-sized ZVI when it is mixed with PS, which could lead to the total PS consumption, not remaining enough to subsequent reaction. This would explain the AMZ degradation profile promoted by nano-sized particles. Although synthesized nZVI continues releasing $\mathrm{Fe}$ (II) up to 30 minutes, no further degradation is observed during this period, probably due to the scavenging effect of excessive Fe(II) (Eq.30). On the other hand, Figure 27B reveals a gradual Fe(II) release from micro-sized ZVI, which leads to a constant PS activation over time (Eq. 9), explaining the continuous AMZ degradation promoted by these particles.

One of the major advantages of using ZVI instead of dissolved Fe(II) to activate persulfate is the ability of the former to continuously activate PS over time, along with a gradual Fe(II) release, which was only observed with micro-sized ZVI. This result is in opposition to what is normally reported, since smaller particles, due to their higher surface areas, generally lead to a higher PS activation due to a higher Fe(II) release. However this can be justified by the low PS concentration used in our experiments.

Notwithstanding, in our experiments micro ZVI was preferred to nano ZVI for PS 
activation to perform further ZVI/PS investigations, given its better performance.
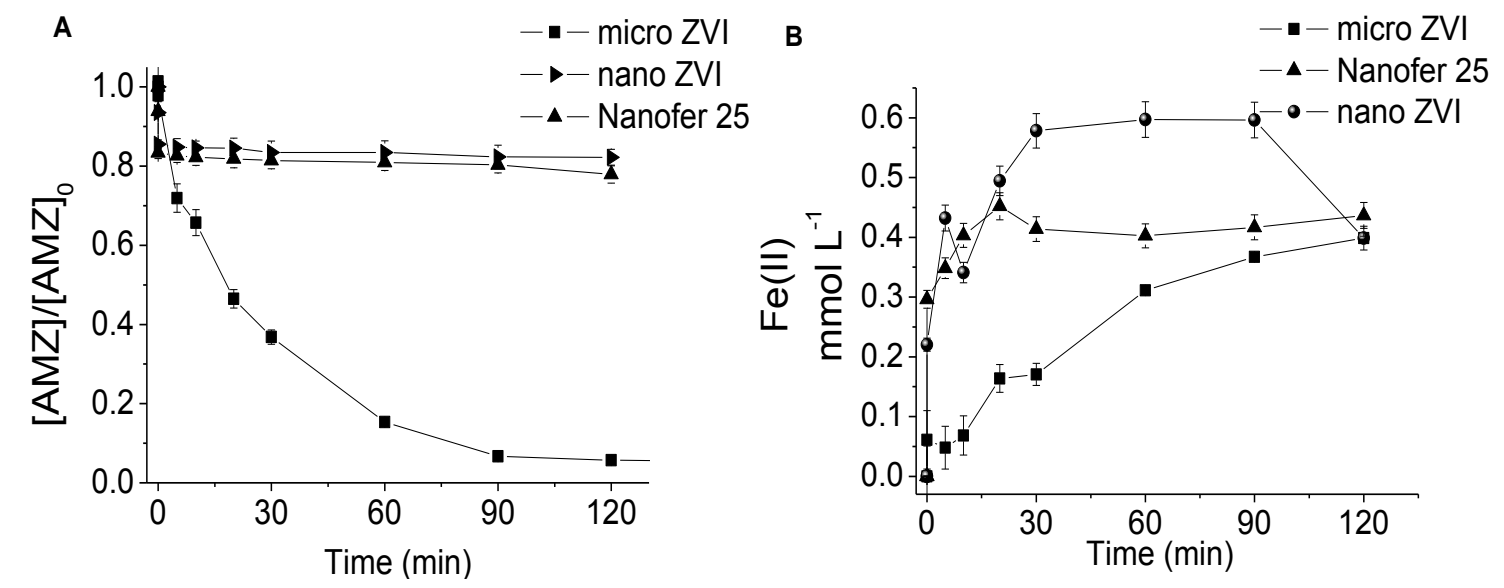

Figure 27. (A) Influence of ZVI source and size on AMZ degradation by the PS/ZVI system (1:1); (B) $\mathrm{Fe}(\mathrm{II})$ released from PS/ZVI (1:1) experiments with micro ZVI, Nanofer 25 and nano ZVI, respectively . $[\mathrm{AMZ}]_{0}=(41.4 \pm 8.0) \mu \mathrm{mol} \mathrm{L}^{-1} ;[\mathrm{ZVI}]_{0}=1 \mathrm{mmol} \mathrm{L}^{-1} ;[\mathrm{PS}]_{0}=1 \mathrm{mmol} \mathrm{L}{ }^{-1} ;$ free $\mathrm{pH} ; \mathrm{pH}_{0} \sim 3$.

\subsubsection{Effect of initial ZVI and PS dosage}

The effect of initial ZVI dosage was investigated by adding different amounts of micro ZVI into a $41.4 \mu \mathrm{mol} \mathrm{L}{ }^{-1}\left(10 \mathrm{mg} \mathrm{L}^{-1}\right)$ AMZ solution, while initial PS concentration was fixed at $1 \mathrm{mmol} \mathrm{L}^{-1}$.

With no $\mathrm{pH}$ adjustment, a gradual $\mathrm{pH}$ increase was observed over time, which is dependent on the initial ZVI dosage. The $\mathrm{pH}$ started increasing earlier (initial $\mathrm{pH}$ around 3 for all the experiments) for higher initial ZVI dosages as expected, since the amount of $\mathrm{OH}^{-}$anions released from iron corrosion is proportional to the initial $\mathrm{Fe}^{0}$ concentration (Eqs. 11-12) (DENG et al., 2014). However, by the time $\mathrm{pH}$ increases (Figure 28A), $\mathrm{Fe}^{2+}$ is no longer available to react with PS (Eq. 9) (Figure 28B), since it is removed by precipitation, and AMZ degradation slows down as a consequence. This is more evident for a ZVI dosage of $20 \mathrm{mmol} \mathrm{L}^{-1}$, for which Fe(II) measurements reveal a significant decrease after 30 minutes of reaction. In Figure $28 \mathrm{C}$ is possible to observe that this slower AMZ degradation stage was reached earlier for higher ZVI initial dosages, which consequently led to less AMZ removals for equal degradation periods. In the same way, AMZ degradation followed a pseudo first-order behavior for shorter times as the ZVI dosage increased. To facilitate comparison between kinetics, the observed degradation rate constants $\left(k_{\mathrm{obs}}\right)$ were all calculated for 30 minutes of reaction, giving the following values: of $3.13 \times 10^{-2} \mathrm{~min}^{-1}$ for PS/ZVI ratio $1: 1,4.0 \times 10^{-2} \mathrm{~min}^{-1}$ for PS/ZVI ratio 1:5 and $1: 10$ and $3.02 \times 10^{-3} \mathrm{~min}^{-1}$ for PS/ZVI ratio 1:20. Another factor that might have 
contributed to less AMZ removals as ZVI dosage increased above $10 \mathrm{mmol} \mathrm{L}^{-1}$ was the $\mathrm{SO}_{4}{ }^{-}$- scavenging by excessive amounts of $\mathrm{Fe}^{2+}$ (Eq. 30), thereby reducing the degradation efficiency. This feature is supported by Fe(II) measurements shown in Figure 28B, since initial Fe(II) release increase with increasing ZVI dosage. Similar results were observed by Wei et al. (2016), who reported that high amounts of ZVI decreased the PS/ZVI efficiency on bentazon degradation due to sulfate radicals scavenging by excessive $\mathrm{Fe}(\mathrm{II})$.
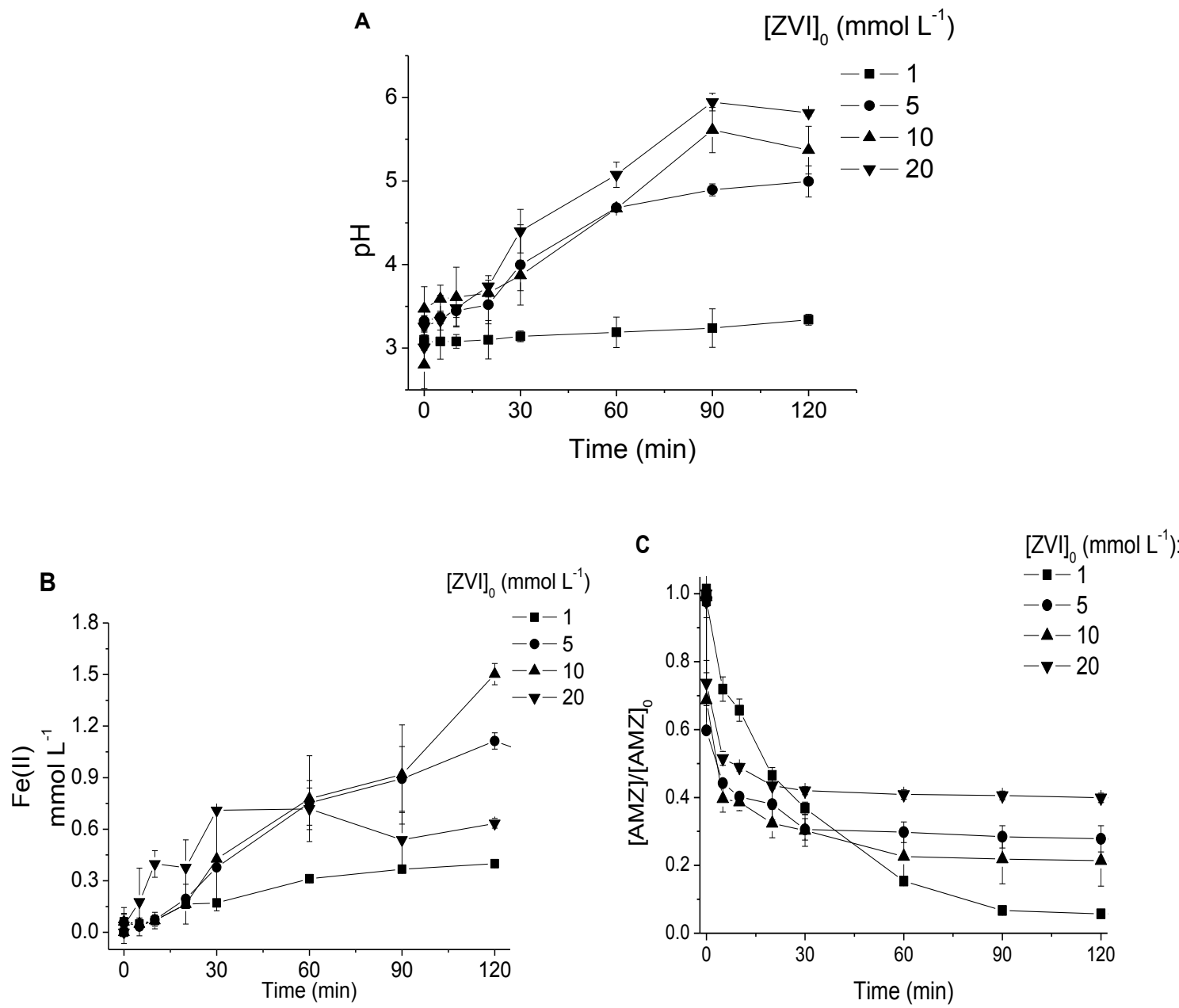

Figure 28. Effect of $[\mathrm{ZVI}]_{0}$ on (A) $\mathrm{pH}$ profile over reaction (B) $\mathrm{Fe}^{2+}$ release during reaction; (C) AMZ degradation by the PS/ZVI system. $[\mathrm{AMZ}]_{0}=(41.4 \pm 8.0) \mu \mathrm{mol} \mathrm{L}^{-1} ;[\mathrm{PS}]_{0}=1 \mathrm{mmol} \mathrm{L}^{-1} ; 1<[\mathrm{ZVI}]_{0}<20$ $\mathrm{mmol} \mathrm{L}{ }^{-1}$; free $\mathrm{pH}, \mathrm{pH}_{0} \sim 3$.

Conversely, the effect of initial PS concentration was investigated by spiking different amounts of PS into a $41.4 \mu \mathrm{mol} \mathrm{L} \mathrm{L}^{-1} \mathrm{AMZ}$ solution, while the initial ZVI dosage was fixed at $5 \mathrm{mmol} \mathrm{L} \mathrm{L}^{-1}$. As expected, AMZ degradation increased by increasing PS initial concentration (Figure 29A), since more radicals were expected to be generated. Also, higher initial PS concentrations kept a lower $\mathrm{pH}$ over the reaction time, since increasing persulfate ions in aqueous solution increased $\mathrm{H}^{+}$release (Eqs. 33 - 34) (GHAUCH; AYOUB; NAIM, 2013). As a consequence, more $\mathrm{SO}_{4}{ }^{-}{ }^{-}$radicals would be 
produced, since the formation and maintenance of ferrous ions $\left(\mathrm{Fe}^{2+}\right)$ in solution (Eq. 32) is favored under acidic conditions (Figure 29B) (WEI et al., 2016), therefore existing more $\mathrm{Fe}^{2+}$ available to react with PS. Also, it is clear in Figure 29B that $\mathrm{Fe}$ (II) measurements up to 30 min decrease with increasing PS concentration, suggesting that, during this period, $\mathrm{Fe}(\mathrm{II})$ consumption is higher than its production, which explains the increasing AMZ degradation. After that, a stagnation phase appears, probably due to excessive $\mathrm{Fe}(\mathrm{II})$ or to a total PS consumption. In this case, $k_{\mathrm{obs}}$ values of $1.5 \times 10^{-2} \mathrm{~min}^{-1}$ and $7.7 \times 10^{-2} \mathrm{~min}^{-1}$ were obtained for PS/ZVI ratios of 0.5:5 and 2.5:5, respectively (both calculated based on data up to 30 minutes of reaction).

$$
\begin{aligned}
& 2 \mathrm{~S}_{2} \mathrm{O}_{8}^{2-}+2 \mathrm{H}_{2} \mathrm{O} \rightarrow 4 \mathrm{HSO}_{4}^{-}+\mathrm{O}_{2} \\
& \mathrm{HSO}_{4}^{-} \rightarrow \mathrm{SO}_{4}^{2-}+\mathrm{H}^{+}
\end{aligned}
$$
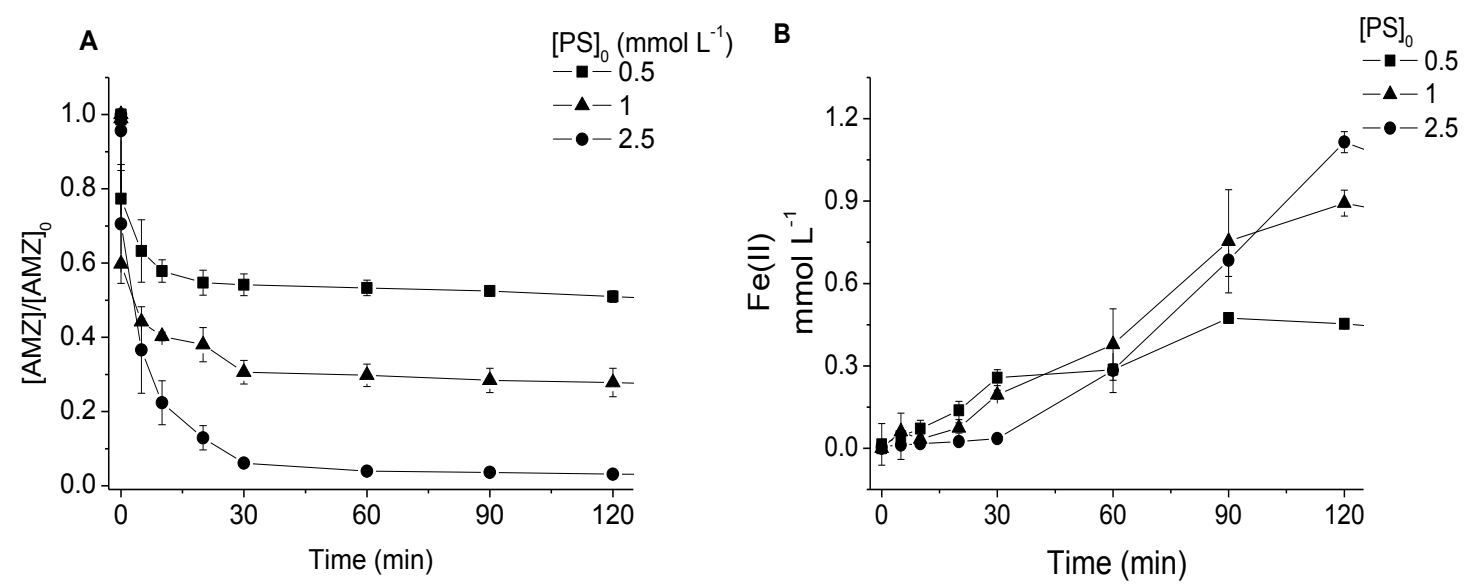

Figure 29. Effect of $[\mathrm{PS}]_{0}$ on (A) AMZ degradation and (B) $\mathrm{Fe}^{2+}$ concentrations at the end of 120 minutes of reaction. $[\mathrm{AMZ}]_{0}=(41.4 \pm 8.0) \mu \mathrm{mol} \mathrm{L}^{-1} ;[\mathrm{ZVI}]_{0}=5 \mathrm{mmol} \mathrm{L}^{-1} ; 0.5<[\mathrm{PS}]_{0}<2.5 \mathrm{mmol} \mathrm{L}{ }^{-1}$; free pH. $\mathrm{pH}_{0}$ $\sim 3$.

The two PS/ZVI ratios that promoted the highest AMZ removal, i.e. 1:1 and 2.5:5, where selected to perform the experiments described in the subsequent paragraphs. Previous studies in which the PS/ZVI system was applied to oxidize organic pollutants, namely acetaminophen and polyvinyl alcohol, also reported a PS/ZVI molar ratio of 1:1 as the optimum (DENG et al., 2014; OH et al., 2009).

\subsubsection{Effect of solution pH}

To evaluate the effect of $\mathrm{pH}$ on $\mathrm{AMZ}$ degradation, experiments were performed at three different $\mathrm{pH}$ values: 3.5, 5 and 8. The effect of $\mathrm{pH}$ on AMZ degradation promoted by the PS/ZVI process for PS/ZVI ratios of 1:1 and 2.5:5 is shown in Figures 30A and 30B, respectively. The PS/ZVI system promoted AMZ degradation over a broad $\mathrm{pH}$ 
range, although with a slower rate at $\mathrm{pH}$ 8. This happened because iron ions are insoluble at such $\mathrm{pH}$, forming precipitates. Even so, for the higher PS/ZVI ratio almost $70 \%$ AMZ removal was achieved under alkaline conditions, indicating that higher loads of ZVI and PS together can overcome this drawback. One of the reasons behind this behavior can rely on the generation of sulfate radicals via the surface reaction (Eq.31) even under slightly alkaline conditions (WENG; TAO, 2015). Another reason is the possibility of generation of stronger oxidizing radicals like hydroxyl radical under alkaline media (Eq. 35):

$\mathrm{SO}_{4}^{\bullet-}+\mathrm{OH}^{-} \rightarrow \mathrm{SO}_{4}^{2-}+\cdot{ }^{\cdot} \mathrm{OH}$

However, it is possible to observe that, for both ratios, at $\mathrm{pH} 8$ the degradation rate starts declining after a certain time. This feature can be attributed to the absence of corrosion under these circumstances, therefore not providing new active sites that could be available in deeper layers of the ZVI particle. Decreasing the number of active sites on ZVI surface, the chance of PS to react via the surface reaction decrease (Eq.31). Under acidic conditions, both ratios enabled AMZ removals below LOQ after 120 minutes of reaction, indicating that lower $\mathrm{pH}$ values are better for such processes, as expected, since iron precipitation occurs in a less extent.
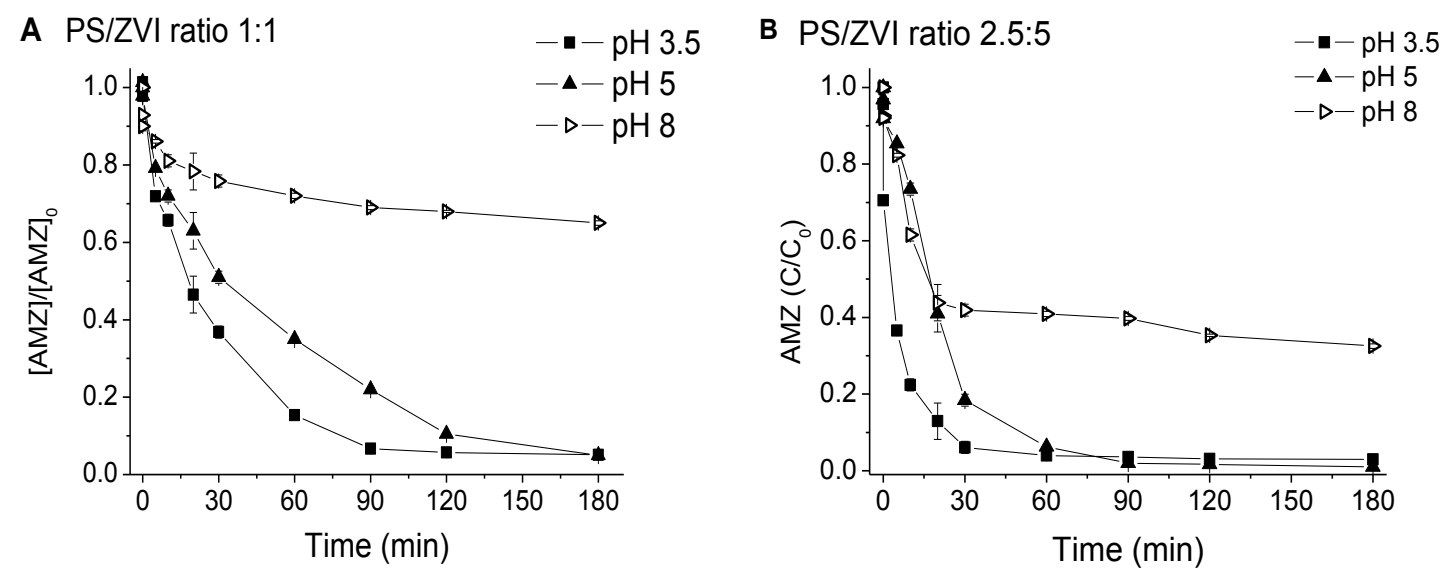

Figure 30. Effect of solution $\mathrm{pH}$ on AMZ degradation by the PS/ZVI system, for PS/ZVI ratios of (A) 1:1 and (B) 2.5:5. $[\mathrm{AMZ}]_{0}=(41.4 \pm 8.0) \mu \mathrm{mol} \mathrm{L}{ }^{-1}$.

Studies where dissolved $\mathrm{Fe}^{2+}$-activated PS was applied to degrade organic pollutants reported that this process is only effective under acidic conditions (CAO et al., 2008; RAO et al., 2014). Given that, our results confirm that ZVI is a much more suitable $\mathrm{PS}$ activator than $\mathrm{Fe}^{2+}$, since it allows working in a wider $\mathrm{pH}$ range. 


\subsubsection{Influence of dissolved oxygen}

The influence of dissolved oxygen was studied here by bubbling high purity $\mathrm{O}_{2}$ or $\mathrm{N}_{2}$ gas in the reaction medium, for the PS/ZVI ratio of 1:1, in the absence or presence of UVA radiation (Figure 30). As shown by Figure 30A1 increasing the content of dissolved oxygen in solution in the dark leads to a slight decrease on AMZ removal after 30 minutes of reaction, while decreasing $\mathrm{O}_{2}$ content by bubbling $\mathrm{N}_{2}$ clearly inhibited AMZ removal. By bubbling $\mathrm{O}_{2}$, the ZVI corrosion increases, resulting in a faster $\mathrm{pH}$ increase (from 3 to 5 in 30 minutes) (Eq. 11), which explains the slower AMZ degradation rate after $30 \mathrm{~min}$ of reaction. On the other hand, by reducing the concentration of dissolved $\mathrm{O}_{2}$, the iron corrosion still occurs but less $\mathrm{Fe}^{2+}$ is released (Eq. 12) (Figure 31A2), which clearly affects AMZ degradation. In the presence of UVA radiation, increasing the content of dissolved $\mathrm{O}_{2}$ greatly enhanced AMZ degradation, while decreasing the $\mathrm{O}_{2}$ concentration did not show any significant impact (Figure 31B). Reducing the $\mathrm{O}_{2}$ availability in the irradiated system does not seem to significantly affect AMZ degradation, since the lower production of sulfate radicals from the $\mathrm{Fe}^{2+}$ activated PS system as a result of less iron corrosion is probably compensated by the production of sulfate radicals by the UVA-activated PS. On the other hand, increasing $\mathrm{O}_{2}$ concentration in the irradiated system has a greater impact than in the dark, since irradiation provides extra radicals via $\mathrm{Fe}(\mathrm{III})-\mathrm{Fe}(\mathrm{II})$ recycling (Eq.18), therefore extending the reaction described by Eq. 9 . 

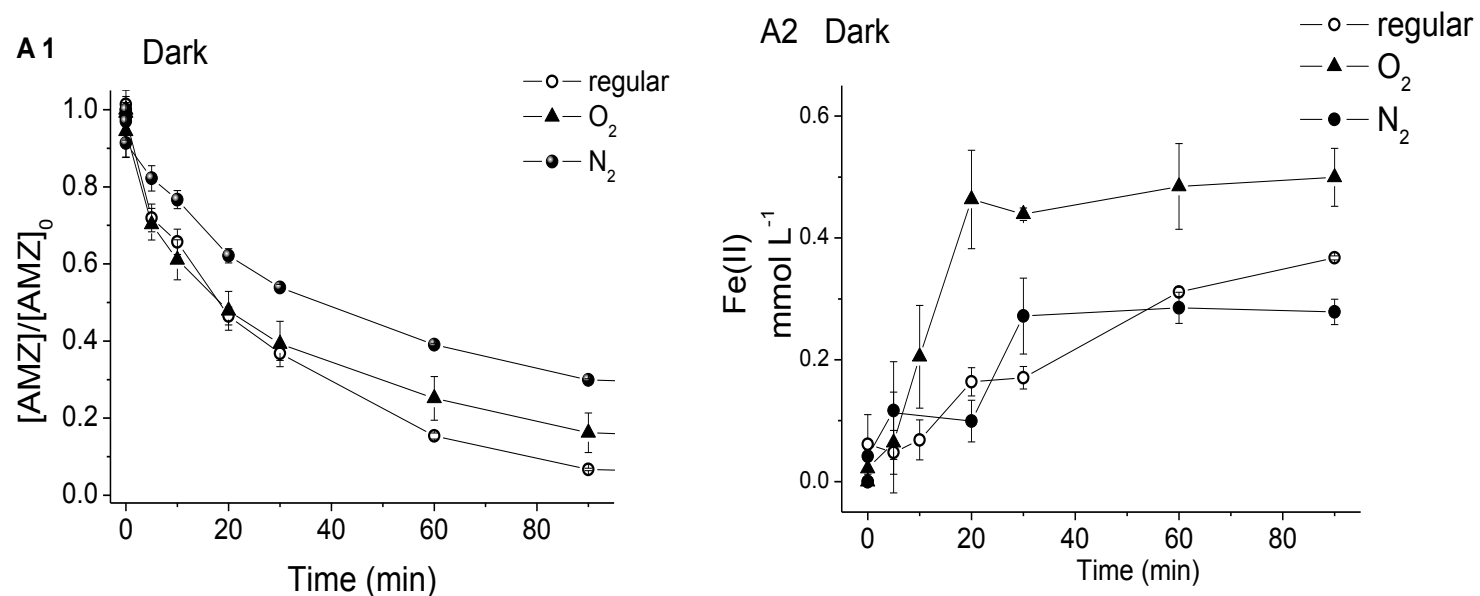

B UVA radiation

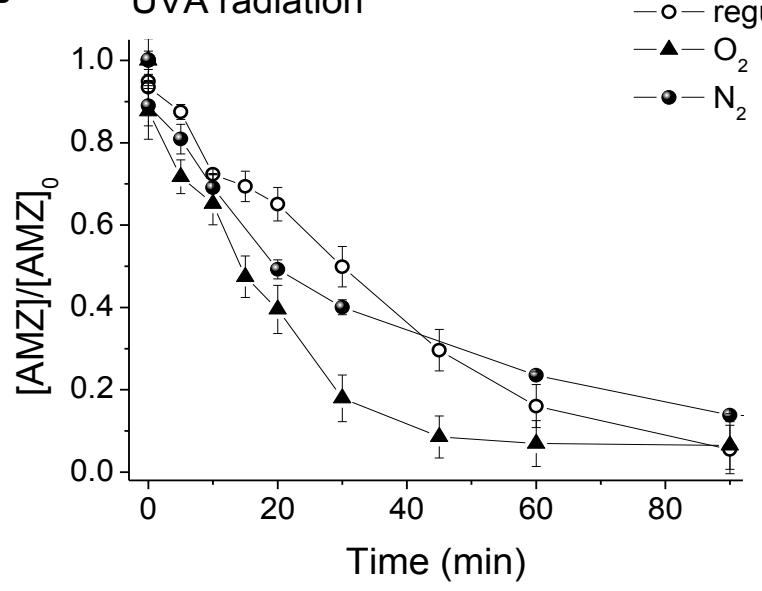

Figure 31. (A1) Influence of dissolved oxygen on AMZ degradation by the PS/ZVI system $\left(1: 1 \mathrm{mmol} \mathrm{L}^{-1}\right)$ in the dark or (B) in the presence of UVA radiation; (A2) Influence of dissolved oxygen on released $\mathrm{Fe}$ (II) during AMZ degradation in the dark; $[\mathrm{AMZ}]_{0}=(41.4 \pm 8.0) \mu \mathrm{mol} \mathrm{L}^{-1}$, free $\mathrm{pH}, \mathrm{pH}_{0} \sim 3$.

\subsubsection{Influence of inorganic constituents of natural waters}

To study the effect of several inorganic ions usually present in natural waters on the performance of PS/ZVI system used to degrade AMZ, experiments were performed using bottled mineral water instead of deionized water. Both PS/ZVI ratios (1:1 and 2.5:5 molar ratios) were tested. It is possible to observe in Figure 32 that, for both PS/ZVI ratios, AMZ degradation in mineral water was a bit faster than in deionized water. The mineral water used in our experiments is rich in $\mathrm{HCO}_{3}{ }^{-}$and $\mathrm{SO}_{4}{ }^{2-}$ anions, well-known radical scavengers (GHAUCH; AYOUB; NAIM, 2013; LI et al., 2015), therefore our results are in opposition to what is usually reported. Nonetheless, differing results like ours were already reported in the literature. For instance, Velosa and Nascimento (2017) have also reported similar results for sulfathiazole degradation present in STP effluent promoted by activated persulfate. Furthermore, there are already evidences in the literature mentioning that the addition of carbonates to activated-persulfate systems can generate reactive carbonate species capable of catalyzing the propagation reactions, 
resulting in more sulfate radicals (BENNEDSEN; MUFF; SØGAARD, 2012), which would explain the higher AMZ degradation observed in mineral water. Moreover, salts are known to increase the rate of iron corrosion (ZAKOWSKI; NAROZNY; SZOCINSKI, 2014), due to an increase in water conductivity, leading to a higher $\mathrm{Fe}^{2+}$ release from ZVI particles, and more $\mathrm{SO}_{4}{ }^{--}$production from the reaction between the latter and PS (Eq.9), as a consequence. Given that, our results indicate that the PS/ZVI system is an attractive alternative for treating (i) Groundwater contaminated with AMZ through on-site active barriers or by pumping and treating off-site; (ii) Contaminated rinsing water generated in land farm use, particularly from spray equipment and containers, water used to wash vegetables and fruits etc; and (iii) Contaminated water from plastic bottles (containing pesticide) washing prior to crushing and pelletization in plastic container recycling operations. For the latest application, the Brazilian Ministry of Agriculture, Livestock and Food Supply (MAPA, normative instruction $\mathrm{n}^{\circ}$ 2, January 3, 2008) already regulates the practice for treatment of effluents, recommending ozonation for the treatment of agricultural effluents. However, up to date there are no published studies regarding the degradation of AMZ-contaminated waters with ozonation, which prevents a direct comparison between the processes applied in the present study with the process recommended by the Brazilian legislation.
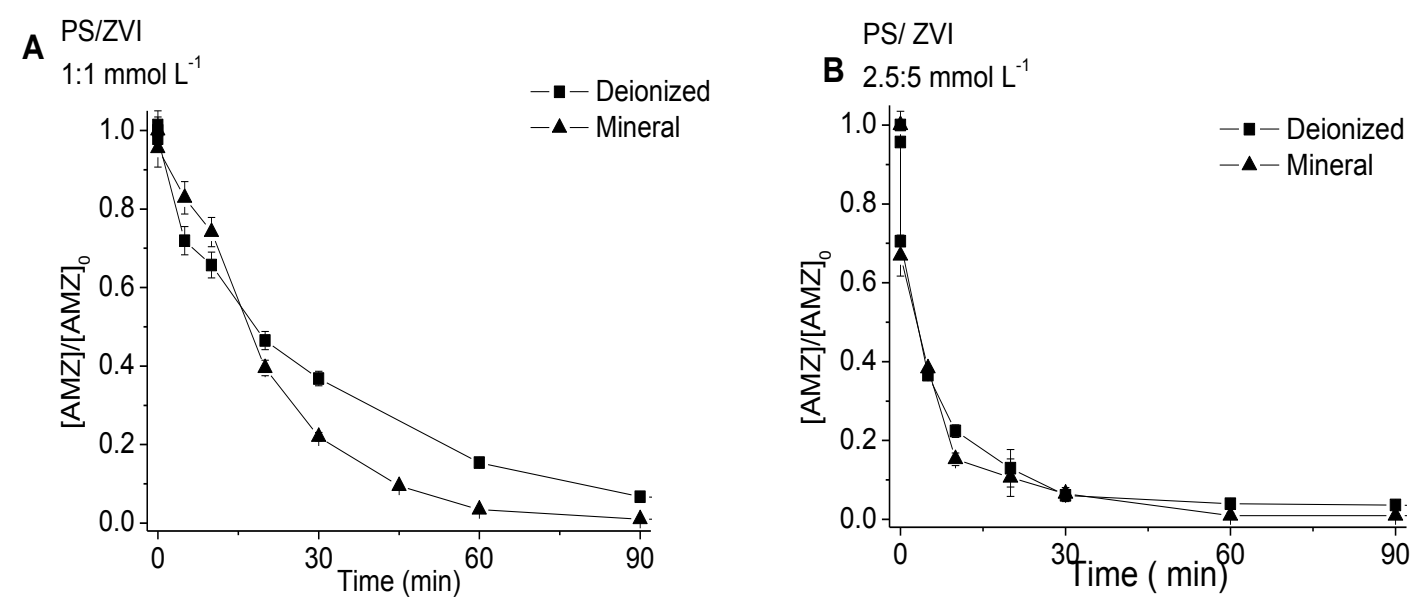

Figure 32. Influence of different water matrices on AMZ degradation by the PS/ZVI system, for PS/ZVI ratios of (A) 1:1 and (B) 2.5/5. [AMZ] $]_{0}=(41.4 \pm 8.0) \mu \mathrm{mol} \mathrm{L}^{-1}$, free $\mathrm{pH}, \mathrm{pH}_{0} \sim 3$.

\subsubsection{Identification of active radicals}

As already mentioned, both ${ }^{\circ} \mathrm{OH}$ and $\mathrm{SO}_{4}{ }^{-}$radicals can be simultaneously produced in the studied system, whether in the absence or presence of UVA radiation. In order to identify the predominant oxidative species for both PS/ZVI ratios, in the absence 
or presence of light, 2-propanol and tert-butyl alcohol (TBA) were used as radical probes to weigh the contributions of $\mathrm{SO}_{4}{ }^{\circ}$ and ${ }^{\circ} \mathrm{OH}$ species on the herbicide removal. These two specific alcohols were chosen because 2-propanol can scavenge both ${ }^{\circ} \mathrm{OH}$ and $\mathrm{SO}_{4}{ }^{--}$with very high rate constants, i.e. $1.9 \times 10^{9} \mathrm{~L} \mathrm{~mol}^{-1} \mathrm{~s}^{-1}$ and $4 \times 10^{7} \mathrm{~L} \mathrm{~mol}^{-1} \mathrm{~s}^{-1}$ (BUXTON et al., 1988; NETA; HUIE; ROSS, 1988), respectively, while TBA is an effective quencher for ${ }^{\circ} \mathrm{OH}\left(k=3.8-7.6 \times 10^{8} \mathrm{~L} \mathrm{~mol}^{-1} \mathrm{~s}^{-1}\right)$ but not for $\mathrm{SO}_{4}{ }^{--}\left(k=4-9.1 \times 10^{5} \mathrm{~L} \mathrm{~mol}^{-1} \mathrm{~s}^{-1}\right)(\mathrm{HAN}$ et al., 2015). To perform these experiments, two different probe/AMZ proportions were used: 500/1 and 1000/1 (molar ratios) and AMZ degradation was followed over the first 90 min of reaction. The results in Table 14 show that 2-propanol dramatically inhibited AMZ degradation for both PS/ZVI ratios, with or without UVA radiation, whereas TBA also suppressed AMZ although to a lesser extent, except for the PS/ZVI ratio 1:1 without UVA irradiation. These results indicate that both ${ }^{\circ} \mathrm{OH}$ and $\mathrm{SO}_{4}{ }^{--}$contributed to the overall removal of $\mathrm{AMZ}$, although $\mathrm{SO}_{4}{ }^{--}$radicals clearly play a more important role. In the case where TBA inhibited AMZ degradation to a greater extent, probably more ${ }^{\circ} \mathrm{OH}$ were participating, since less PS was used $\left(1 \mathrm{mmol} \mathrm{L}^{-1}\right)$ and, in the absence of UVA radiation, an early $\mathrm{pH}$ increase occurred, which might have led to more radical interconversion (Eq. 35) than in any other case.

Table 14. Effect of 2-propanol and TBA on AMZ degradation by the PS/ZVI system, for PS/ZVI ratios of $1: 1$ and 2.5:5 $\left(\mathrm{mmol} \mathrm{L}^{-1}\right)$, in the absence and presence of UVA radiation.

\begin{tabular}{ccccccc} 
& & \multicolumn{4}{c}{ AMZ removal (\%) in 90 min of reaction } \\
\cline { 3 - 7 } & PS/ZVI ratio & Without quencher & 2-propanol & \multicolumn{2}{c}{ TBA } \\
\cline { 3 - 7 } & & & $500 / 1$ & $1000 / 1$ & $500 / 1$ & $1000 / 1$ \\
\hline Without & $1: 1$ & 94.8 & 19 & 5 & 29 & 44 \\
UVA & $2.5: 5$ & 97 & 30 & 15 & 97 & 50 \\
\hline With & $1: 1$ & 94.5 & 8 & 10 & 60 & 77 \\
UVA & $2.5: 5$ & 98.8 & 28 & 13 & 93 & 98.8
\end{tabular}

\subsection{Partial Conclusions}

In this study, the suitability of ZVI as a PS activator for the degradation of the herbicide amicarbazone (AMZ) was investigated. The effects of variables such as ZVI size, PS/ZVI ratio, suspension $\mathrm{pH}$, dissolved oxygen content, UVA radiation and 
presence of inorganic ions on the PS/ZVI system were evaluated in terms of AMZ removal. Our results indicated that micro-sized iron performed better than the two other nano-sized iron sources, and increasing its dosage above $10 \mathrm{mmol} \mathrm{L}^{-1}$ negatively affected the PS/ZVI system. However, this negative effect can be surpassed by increasing the PS concentration. Slightly alkaline conditions were found not to be the most adequate for the PS/ZVI system, although significant AMZ removals were still possible to achieve under such conditions, with a high PS/ZVI ratio, which revealed to be an advantage of using a solid iron source. The incidence of UVA radiation alone did not seem to significantly affect the PS/ZVI system, but together with a higher content of dissolved oxygen it boosts AMZ degradation. Even in the absence of light, oxygen was proved to play an important role in this process. Contrary to what is usually reported, the presence of inorganic ions revealed to slightly enhance $\mathrm{AMZ}$ degradation, which can be attributed to the catalyzed sulfate radicals production by carbonate reactive species. Tests with radical scavengers confirmed that the major active species taking part in the process studied is the sulfate radical. Given that, our research demonstrates that ZVI can be an effective alternative to PS activation applied for water decontamination purposes. 


\section{GENERAL CONCLUSIONS OF CHAPTER I}

Comparing all the processes applied for AMZ degradation, is possible to conclude that those using UVA-activated persulfate together with $\mathrm{Fe}(\mathrm{III})$-carboxylate complexes achieved better results, taking into account the time needed to remove the pesticide below quantifiable levels. However, these same processes resulted in more toxic solutions towards three of five organisms tested in toxicity assays, which turns them not suitable for practical application. Among the processes which enabled a toxicity reduction towards most of the organisms tested, UVA-activated persulfate seems to be the most attractive for practical application, given its effectiveness (high AMZ removals in 120 minutes) either in acid ( $\mathrm{pH}$ 1.6) or neutral ( $\mathrm{pH} 7)$ media. Another process that showed high AMZ removals (>92.5\% in 90 minutes) within "real" conditions was ZVI-activated persulfate, although nothing is known about the toxicity of treated solutions. However, considering that $\mathrm{Fe}(\mathrm{II})$ and $\mathrm{Fe}(\mathrm{III})$ are released from $\mathrm{ZVI}$ along the process, and, at the end, solid iron has to be separated from the solution to evaluate its toxicity, it can be predicted that this process will also give more toxic solutions than the initial AMZ solution towards the majority of organisms tested, based on the results shown in section 6. Notwithstanding, to make a better assessment regarding processes applicability, environmental concentrations in which pesticides are usually detected (ng L $\mathrm{L}^{-1}$ or $\mu \mathrm{g} \mathrm{L}^{-1}$ ) should be tested, as well as processes performance in real water matrixes. Besides that, an economic assessment could serve as a complementary tool to evaluate processes applicability, but further investigation regarding overall costs associated with each process is necessary. 


\section{CHAPTER II}

\section{DEGRADATION OF PERSISTENT}

\section{PESTICIDES VIA REDUCTIVE PROCESSES}




\section{Water remediation with reductive processes}

Organohalogens are an important class of contaminants that may degrade very slowly when submitted to an oxidative treatment due to their electrondeficient/withdrawing group (halogen), therefore being more effectively eliminated when their initial treatment is undertaken in a reducing (electron-rich) environment (PEREIRA; FREIRE, 2005; SATAPANAJARU; ANURAKPONGSATORN, 2008). Given that, a growing number of researchers have been studying the elimination of these contaminants using zero-valent metals as chemical reducing agents (SARATHY et al., 2010). ZeroValent Iron (ZVI) has been the most applied metal for this purpose due to its abundance and non-toxic character, successfully degrading a wide range of persistent pollutants containing halogens, such as pesticides (BEZBARUAH; THOMPSON; CHISHOLM, 2009) and azo-dyes (ZAMORA P. P.; SOUZA C. L., 2006; ZHAO et al., 2008). The redox pair formed by ZVI $\left(\mathrm{Fe}^{0}\right)$ and ferrous ion $\left(\mathrm{Fe}^{2+}\right)$ has a standard reduction potential of $-0.440 \mathrm{~V} \mathrm{SHE}$, which means that this is a relatively strong reducing agent relative to many redox-labile substances, including hydrogen ions, carbonate and nitrate (HWANG; KIM; SHIN, 2011; PEREIRA; FREIRE, 2006). Under aerobic conditions, oxygen is the major electron acceptor, while under anaerobic conditions, the organohalogenated compounds can be the final electron acceptors from ZVI oxidation. In a $\mathrm{ZVI}-\mathrm{H}_{2} \mathrm{O}$ system this process can occur by three possible ways: i) direct electron transfer from the ZVI surface to the adsorbed organohalogen (Figure. 33A); ii) reduction promoted by dissolved $\mathrm{Fe}^{2+}$ coming from ZVI corrosion (Figure 33B); iii) catalyzed hydrogenation by the hydrogen produced from ZVI reaction with water (Figure 33C).

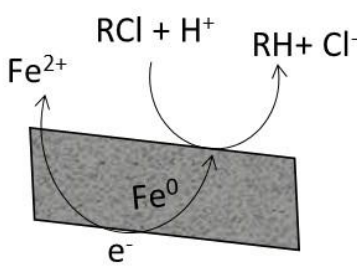

(A)

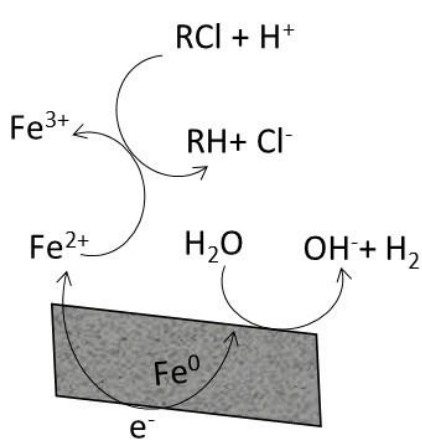

(B)

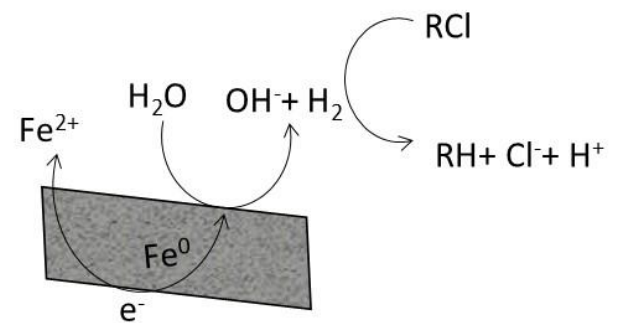

(C)

Figure 33. Proposed pathways for the reductive dehalogenation in anoxic $\mathrm{Fe}^{0}-\mathrm{H}_{2} \mathrm{O}$ systems.

Several laboratory-scale studies revealed effective reduction of alkyl halides in aqueous solution, which encouraged the practical application of this process for in situ remediation of contaminated groundwater. For example, Gilham and co-workers (1994) 
developed a pilot-scale field study where a permeable barrier containing granular ZVI filings and sand was emplaced perpendicular to the path of an artificial plume of chlorinated hydrocarbons, as illustrated in Figure 34. The results showed that the barrier promoted effective chemical reduction of perchloroethylene (PCE) and TCE and no decline in the performance was observed over five years. The success of this field demonstration attracted considerable attention, especially because it consisted in a costeffective alternative to conventional groundwater treatment methods ( GILLHAM; RITTER, 1994).

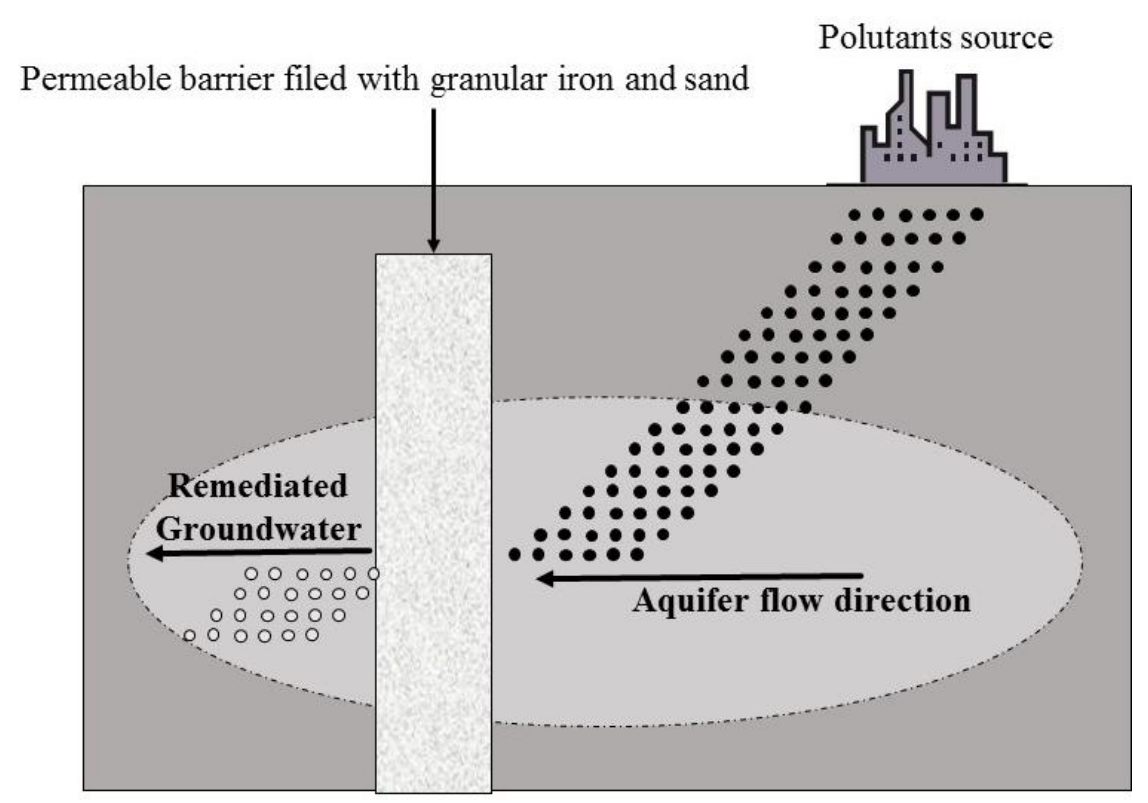

Figure 34. Schematic permeable reactive barrier (PRB) for in situ treatment with ZVI of groundwater containing halocarbons (adapted from Pereira and Ferreira, 2005).

Particles reactivity has a straight relationship with surface area, so nanoparticles are expected to be more efficient in organochlorinated reduction than microparticles. The first application of nano-sized ZVI (nZVI) was in the dechlorination of TCE and polychlorinated biphenyls (PCBs) by Wang and Zhang (1997), which has triggered further research activities devoted to enhance the performance of ZVI for contaminants removal. This is one of several countermeasures that can be made to improve ZVI efficiency. In fact, over the past two decades efforts have been made to overcome ZVIbased technologies limitations so that the efficiency for contaminants removal can be improved. One major limitation of this technology is the loss of ZVI reactivity over time due to surface passivation caused by the corrosion products (e.g. $\mathrm{Fe}(\mathrm{OH})_{2}, \mathrm{Fe}(\mathrm{OH})_{3}$ and $\mathrm{FeCO}_{3}$ on the surface of ZVI), as well as by some contaminants (GUAN et al., 2015). Countermeasures to overcome this limitation usually rely on physical and chemical 
enhancements of ZVI particles, such as surface pretreatment (e.g. acid washing and $\mathrm{H}_{2}-$ reduction), coupling ZVI with other materials (e.g. ZVI/CMC, ZVI/bentonite, ZVI/zeolite), ZVI-based bimetals (ZVI/Pd, ZVI/Ag, ZVI/Cu), among others (CAO et al., 2011; LIEN; ZHANG, 2005; MATHESON; TRATNYEK, 1994; MORALES; HUTCHESON; CHENG, 2002; SHI; ZHANG; CHEN, 2010; ZIN et al., 2013).

Besides iron, other zero-valent metals have been studied as potential reactive materials in permeable barriers, such as zinc (Zn) and tin (Sn) (TRATNYEK et al., 2003), although $\mathrm{Zn}$ reveals to be more attractive given its lower reduction potential $\left(\mathrm{E}_{\mathrm{Zn}}^{0}=\right.$ -0.762 V SHE) (STEVEN G. BRATSCH, 1988), thus providing electrons for reductive dechlorination more easily and enlarging the number of contaminants available for a reduction treatment. Some organochlorines effectively degraded by $\mathrm{Zn}^{0}$ include carbon tetrachloride (TRATNYEK et al., 2010), N-Nitrosodimethylamine (HAN et al., 2012), chlorinated phenols (KIM; CARRAWAY, 2003), among others. However, the $\mathrm{Zn}^{2+}$ generated in the reaction of $\mathrm{ZVZ}$ with a chlorinated contaminant might be a concern to human health due to its toxicity. Notwithstanding, there is a way to remediate the release of toxic $\mathrm{Zn}^{2+}$ by the addition of hydroxyapatite, onto which the $\mathrm{Zn}^{2+}$ is removed by adsorption, recovering $\mathrm{Zn}^{0}$ as an attractive choice (MAVROPOULOS, 1999).

Surface-catalyzed iron and zinc in the form of bimetallic particles $(\mathrm{Fe} / \mathrm{Pd}, \mathrm{Zn} / \mathrm{Pd}$, $\mathrm{Fe} / \mathrm{Ni}, \mathrm{Zn} / \mathrm{Ni}, \mathrm{Zn} / \mathrm{Cu}$ ) have been successfully applied in the degradation of recalcitrant chlorinated contaminants, such as 2,4,6-trichlorophenol (CHOI; KIM, 2009) and 1,2,3,4tetrachlorodibenzo-p-dioxin (WANG et al., 2010). In these systems, the secondary metal onto the primary metal surface (ZVI or Zn) plays two main roles: i) to promote the catalytic hydrodehalogenation (process illustrated in Figure 33C) and hydrogenation reactions on the surface of the primary metal via the $\mathrm{H}_{2}$ released from the corrosion of the primary metal; ii) to enhance the corrosion of the primary metal. When two metals contact, the corrosion of one metal increases and that of the other decreases due to differences in standard electrode potentials. Enhanced corrosion through this mechanism supplies electrons to the second metal on which the electron transfer occurs. This is why noble metals, such as $\mathrm{Pd}, \mathrm{Ni}$ and $\mathrm{Cu}$ are usually applied as secondary metals on bimetallic particles.

Notwithstanding, the addition of the secondary metal has to be economically justified, and the bimetallic material has to be environmentally acceptable. For instance, 
although Pd reveals an effective catalyst role when applied to coat zero-valent metals (LIEN; ZHANG, 2005; WANG et al., 2010), it may not be economically attractive at the field scale. Instead, $\mathrm{Ni}$ or $\mathrm{Cu}$ may be more promising secondary metals for such purpose. Another aspect to take into account is the load of the second metal onto the zero-valent metal particles, which is crucial in the overall rate of contaminant degradation. Bransfield; Cwiertny and Roberts (2006) investigated the reduction of 1,1,1-TCA with $\mathrm{Cu} / \mathrm{Fe}$ and proved that the most dramatic increase in rate constants occurred with relatively low levels of secondary metal loading (BRANSFIELD; CWIERTNY; ROBERTS, 2006).

Given its structural properties, chlorpyrifos $(\mathrm{CP})$ can be considered a suitable target to be degraded via zero-valent metals. As aforementioned, ZVI-based methods represent a new generation of environmental technologies that provide highly effective and low-cost solutions for water remediation, especially when the target is a halocarboncontaminated water matrix (REDDY et al., 2013). Advanced Oxidation Processes (AOPs) are also a possible way to degrade $\mathrm{CP}$, since several studies have reported its successful degradation through photocatalytic oxidation $\left(\mathrm{TiO}_{2} / \mathrm{UV}\right.$ ) (MUHAMAD, 2010), UV/ $\mathrm{H}_{2} \mathrm{O}_{2}$ (WU; LINDEN, 2010), heterogeneous ozonation (MENG et al., 2010), photo-Fenton and photo-Fenton-like reactions (DERBALAH; ISMAIL; SHAHEEN, 2013), although these processes use expensive reactants and expensive apparatus, which are important drawbacks at the full scale level. Besides, CP oxidation products, namely CP oxon, can be more toxic than the parent-compound (WU; LAIRD, 2003).

Reddy et al. (2013) showed that nano-scale ZVI can be successfully used to remediate chlorpyrifos-contaminated soils under anoxic environment at room temperature and pressure. Other research works published up to date using zero-valent metals to degrade CP are listed in Table 15: 
Table 15. Zero-valent metals used in chlorpyrifos degradation.

\begin{tabular}{c|c}
\hline Metal & Reference \\
\hline Nano-sized ZVI & REDDY et al. (2013) \\
Ag and Au nanoparticles & BOOTHARAJU and \\
Ag nanoparticles supported on \\
cellulose acetate membrane \\
Ag nanoparticles supported on \\
alumina powder & SHANTHAKUMAR (2014) \\
Carboxymethyl Cellulose (CMC) & NAIR and PRADEEP \\
stabilized ZVI and ZVI/Ag & REDDY et al. (2015) \\
nanoparticles & \\
\hline
\end{tabular}

\section{OBJECTIVES}

In the present chapter the ability of different zero-valent metals and bimetallic particles $(\mathrm{Fe} / \mathrm{Cu}$ and $\mathrm{Zn} / \mathrm{Cu})$ to degrade the insecticide $\mathrm{CP}$ in an aqueous solution was explored. The main objectives were:

i) To investigate $\mathrm{CP}$ degradation kinetics with different ZVMs and bimetallic particles;

ii) To calculate the apparent degradation rate constant $\left(k_{\text {obs }}\right)$ and the specific degradation rate constant $\left(k_{\mathrm{SA}}\right)$ of each metal, in order to determine the most effective on $\mathrm{CP}$ degradation;

iii) To perform the structural characterization of both synthesized and commercial particles used in the degradation studies;

iv) To identify $\mathrm{CP}$ degradation by-products promoted by the ZVMs tested and compare these products with those reported in other investigations. 


\section{ANAEROBIC DEGRADATION OF CHLORPYRIFOS BY ZERO-VALENT MONOMETALLIC AND BIMETALLIC PARTICLES IN SOLUTION}

Chlorinated organic compounds are broadly present in our daily life, making part of several solvents, lubricants, pesticides, dyes, pharmaceuticals, etc. (GRIBBLE, 1995). However, when released into environment, these compounds may pose high risk to several organisms, due to their general toxic character and environmental persistence (MANAHAN E., 2013). Despite existing strict regulations for control and monitoring of such contaminants, there are many cases in which safety standards are not met. Detection of alarming quantities of these toxic compounds in environmental samples, especially in water, makes urgent the need of developing effective remediation techniques. In general, these pollutants are resistant to conventional water treatment methods, therefore being important to investigate innovative alternatives. Among them, advanced oxidation processes (AOPs) have revealed to be very effective against several persistent pollutants (OPPENLÄNDER, 2003), although in the specific case of halogenated contaminants they may not be effective since these compounds are usually difficult to oxidize (MUNTER, 2001). In fact, oxidation of chlorinated organic compounds may lead to the generation of even more toxic products, as already mentioned for the case of CP. Given that, for these kind of substances, an initial reductive treatment is preferred to an oxidative treatment (SATAPANAJARU; ANURAKPONGSATORN, 2008).

With the aim of evaluating the effect and mechanism of different metallic particles in $\mathrm{CP}$ removal, in the present study was investigated the anaerobic CP degradation promoted by several ZVM. In order to compare the efficiency of different metals, $\mathrm{Cu}^{0}$, $\mathrm{Fe}^{0}, \mathrm{Zn}^{0}$, as well as bimetallic particles obtained by the mixture of these metals, were studied. Beyond this, here was also compared the influence of iron particles size, as well as different pretreatments on particles surface, on CP degradation. To the best of our knowledge, this is the first time that $\mathrm{Zn}^{0}, \mathrm{Cu}^{0}$ and bimetallic particles containing copper are tested as $\mathrm{CP}$ reducing agents. Moreover, although there are other studies reporting CP degradation with other ZVM, none of them comprise such a wide variety of metallic materials, which consists in an important assessment regarding ZVM field application in CP-contaminated sites. Furthermore, different metals can promote different degradation mechanisms, leading to different degradation intermediates. Following that, in this study CP degradation products generated from the reaction with each metal were identified by 
LCMS, aiming the comparison with degradation compounds already reported in other investigations (BOOTHARAJU; PRADEEP, 2012; REDDY et al., 2013).

\subsection{Materials and Methods}

\subsubsection{Chemicals}

Technical grade (> 97\% w/w) samples of chlorpyrifos were obtained from Fersol Indústria e Comércio S/A. and used with no further purification.

Micro-scale ZVI particles and $\mathrm{Cu}^{0}$ were purchased from J.T. Baker (U.S.A), micro-scale $\mathrm{Zn}^{0}$ particles were purchased from Nuclear. These particles were used as received, excepting when the previous surface treatment influence was studied.

All the other chemicals used in this study were of analytical grade.

\subsubsection{Synthesis of Zero-Valent-Iron nanoparticles (nZVI)}

ZVI nanoparticles were prepared by reduction of ferrous iron using sodium borohydride (Eq. 36), according to the methodology described by Ponder et al. 2000, which involves the following reaction:

$2 \mathrm{Fe}^{2+}+\mathrm{BH}_{4}^{-}+2 \mathrm{H}_{2} \mathrm{O} \rightarrow 2 \mathrm{Fe}^{0}+\mathrm{BO}_{2}^{-}+4 \mathrm{H}^{+}+2 \mathrm{H}_{2}$

Shortly, $6.83 \mathrm{~g}$ of $\mathrm{FeSO}_{4} \cdot 7 \mathrm{H}_{2} \mathrm{O}$ were dissolved in $250 \mathrm{~mL}$ of deionized water and $\mathrm{pH}$ was adjusted to 6.8 by using $6-\mathrm{mol} \mathrm{L}^{-1} \mathrm{NaOH}$ solution. The sodium borohydride solution was obtained by dissolution of $1.86 \mathrm{~g}$ of $\mathrm{NaBH}_{4}$ in $125 \mathrm{~mL}$ of deionized water. Excess reagent borohydride (four times in excess) was used in order to improve the growth of iron nanoparticles. Then, the borohydride solution was added drop by drop at a rate of $34 \mathrm{~mL}$ per minute into iron sulphate solution under vigorous stirring. After adding the whole $\mathrm{NaBH}_{4}$ solution, the mixture was stirred for additional 20 minutes under nitrogen flux and then washed three times with deionized water and kept in a $2.5 \%(\mathrm{w} / \mathrm{V})$ suspension in a $50 \% \mathrm{MeOH}$ solution at $4{ }^{\circ} \mathrm{C}$ for no more than 3 days until its use.

\subsubsection{Synthesis of bimetallic particles}

\subsubsection{Synthesis of bimetallic nano $\mathrm{Fe} / \mathrm{Cu}$ with $5 \%(w / w)$ of copper}

The methodology used to synthesize these particles was adapted from Zin et al. (2013): Freshly prepared nZVI particles were added into $\mathrm{CuSO}_{4}$ solution under vigorous mechanical stirring for 2 hours, at room temperature. $\mathrm{CuSO}_{4}$ solution was prepared by 
dissolving $\mathrm{CuSO}_{4} \cdot 5 \mathrm{H}_{2} \mathrm{O}$ in ethanol-water (9:1) solution and the amount of cooper mixed depended on the desired mass of copper. As the mass desired was 5\% (w/w), $0.24 \mathrm{~g}$ of copper salt (containing $0.0625 \mathrm{~g}$ of $\mathrm{Cu}$ ) was weighed for $1.25 \mathrm{~g}$ of freshly prepared nZVI. The particles were then washed with $50 \% \mathrm{MeOH}$ solution three times, kept in a $2.5 \%$ $(\mathrm{w} / \mathrm{V})$ slurry and stored at $4{ }^{\circ} \mathrm{C}$ for no more than three days before use.

\subsubsection{Synthesis of bimetallic micro $\mathrm{Fe} / \mathrm{Cu}$ and micro $\mathrm{Zn} / \mathrm{Cu}$ containing $5 \%$ (w/w) of copper}

The methodology used to synthesize these particles was adapted from Kim and Carraway, (2003): $1 \mathrm{~g}$ of the respective metal powder was washed with $10 \mathrm{~mL}$ of $0.4 \%$ (v/v) $\mathrm{H}_{2} \mathrm{SO}_{4} / 1 \mathrm{~g}$ of metal for $10 \mathrm{~min}$ and then added to $100 \mathrm{~mL}$ of a $\mathrm{CuSO}_{4} .5 \mathrm{H}_{2} \mathrm{O}$ solution. Zinc powder from Nuclear was used to synthesize micro $\mathrm{Zn} / \mathrm{Cu}$ particles. The copper solution was prepared as described in the previous section. Contents were then mixed on a shaker table for $2 \mathrm{~h}$, rinsed with purified water and ethanol and dried in a vacuum stove at $40{ }^{\circ} \mathrm{C}$ during $24 \mathrm{~h}$. After that, particles were stored in vials kept inside sealed bags in desiccators for no more than three days before use.

\subsubsection{Degradation experimental procedures}

Chlorpyrifos has a very low solubility in water $\left(\sim 2 \mathrm{mg} \mathrm{L}^{-1}\right)$ (RACKE; LASKOWSKI; SCHULTZ, 1990), which could compromise its detection in our analytical instruments. Given that, in order to have detectable concentrations in solution for convenient study, a 1 to 1 mixture of water and methanol was used as a solvent in the reactors. A $10-\mathrm{mL}$ chlorpyrifos solution $\left(100 \mathrm{mg} \mathrm{L}^{-1}, 50 \% \mathrm{MeOH}\right)$ was mixed with the corresponding amount of metal in a $20-\mathrm{mL}$ vial, under inert atmosphere $\left(\mathrm{N}_{2}\right)$, in order to avoid metal oxidation. Preliminary baseline experiments under varying reaction conditions (different nZVI concentrations) were conducted to examine the effect of metal concentration on $\mathrm{CP}$ degradation, in order to optimize the process. After that, the optimized amount of metal was added to the pesticide solution, in order to obtain the same final concentration for all the metals. This step was performed inside a glove-bag under $\mathrm{N}_{2}$ atmosphere where all the vials were prepared and sealed with a septum and an aluminum crimped cap. Each vial corresponds to an individual point in the degradation profile and was repeated twice. Along the reaction time, the sacrificial vials were submitted to an end-over-end agitation process. At designed times, the whole samples were collected and immediately filtered through $0.22 \mu \mathrm{m}$ PVDF membranes (micro sized 
particles) or centrifuged at $8000 \mathrm{~g}$ (nano sized particles) to separate the particles from the solution.

Micrometric metal powders were submitted to an additional trial test in order to evaluate if the pre-surface treatment influenced CP degradation. Here metal particles were immersed in pure reaction medium (50\% water: $50 \% \mathrm{MeOH}$ mixture) for $24 \mathrm{~h}$ or previously washed with $\mathrm{H}_{2} \mathrm{SO}_{4} 0.4 \%$ (v/v) before starting the reaction.

\subsubsection{Analytical methods}

Chlorpyrifos concentration was monitored by HPLC, using a C18 column, 85\% MeOH: $15 \% \mathrm{H}_{2} \mathrm{O}$ (1\% acetic acid) as mobile phase, flow rate of $1 \mathrm{~mL} \mathrm{m^{-1 }}$. The injection volume was $50 \mu \mathrm{L}$, the column temperature was maintained at $40{ }^{\circ} \mathrm{C}$ and two wavelength were used: $290 \mathrm{~nm}$ to detect chlorpyrifos and $320 \mathrm{~nm}$ to detect one of its most reported degradation products - 3,5,6-Trichloro-2-Pyridinol (TCP) (MORTLAND; RAMAN, 1967). The limits of detection (LOD) and quantification (LOQ) of chlorpiryfos were $0.49 \mathrm{mg} \mathrm{L}^{-1}$ and $1.46 \mathrm{mg} \mathrm{L}^{-1}$, respectively (determined as described in APPENDIX B).

Chloride concentration was determined by an ion chromatography equipment from Metrohm ${ }^{\odot}$, with a conductivity detector (850 Professional IC 1), column Metrosep A Supp 5 - 150/4 and using $3.2 \mathrm{mmol} \mathrm{L}^{-1}$ of sodium carbonate and $1.0 \mathrm{mmol} \mathrm{L}^{-1}$ of sodium bicarbonate as the mobile phase. The limits of detection (LOD) and quantification (LOQ) of chloride were $0.094 \mathrm{mg} \mathrm{L}^{-1}$ and $0.283 \mathrm{mg} \mathrm{L}^{-1}$, respectively.

In some samples, released $\mathrm{Fe}, \mathrm{Zn}$ and $\mathrm{Cu}$ concentrations were measured. These samples were immediately filtered and acidified before being subjected to atomic absorption spectrometry (AAS) (AA-7000 atomic absorption spectrophotometer from Shimadzu).

Particles surface areas (BET) were measured using the nitrogen adsorption method with a Micromeritics ASAP 2020 surface analyzer. Particles morphology was observed with a Phenom Pro-X scanning electron microscopy coupled to X-ray microanalysis (SEM-EDS) or with a Jeol JSM-7401F scanning electron microscopy coupled to a field emission gun (SEM-FEG), to characterize the size and size distribution of the metal particles. The crystal structures and phase purity were examined with a Rigaku miniflex 300 automated powder X-ray diffractometer (XRD) with nickel filtered $\mathrm{CuK} \alpha$ radiation $(\lambda=0.1542 \mathrm{~nm})$. 
The oxidation state of the bimetallic particles surface was investigated via X-Ray absorption spectroscopy (XAS), using the X-Ray Absortion Fine Structure I (XAFS1) beamline of the Brazilian Synchrotron Light Laboratory (LNLS).

Qualitative mass spectrometric analyses of $\mathrm{CP}$ and its transformation products were carried out using hybrid ion trap/time-of-flight equipment (Shimadzu LCMS-ITTOF) operated in tandem configuration (MS/MS). The sample was nebulized and ionized at atmospheric pressure electrospray type-probe (ESI) in positive and negative mode. Sample drying was performed with nitrogen gas with a minimum purity of 99\%, pressure of $180 \mathrm{kPa}$ and $11 \mathrm{~L} \mathrm{~min}^{-1}$. The electrospray probe (ESI) was operated at $4.5 \mathrm{kV}$. The dissolvation curved line (CDL) interface was operated at $200{ }^{\circ} \mathrm{C}$. The fragmentation of the molecules in tandem mass mode $\left(\mathrm{MS}^{n}\right)$ was performed by collision-induced dissociation with $\operatorname{Ar}(>99.99 \%)$, with a collision-induced dissociation (CID) energy of $50 \%$.

\subsection{Results and discussion}

\subsection{1- Particles characterization}

The commercial and synthetized particles were analyzed by SEM-EDS or SEMFEG in order to verify their morphology. By the analysis of images (Figure 35, A-G) it is possible to say that, except for micro $\mathrm{Zn} / \mathrm{Cu}$, all the particles show approximately spherical shape. Also, except for $\mathrm{Cu}^{0}$, micro $\mathrm{Zn} / \mathrm{Cu}$ and micro $\mathrm{Fe} / \mathrm{Cu}$ particles, all the particles tend to agglomerate in a larger sphere or into a "pearls collar" structure (ZVI nanoparticles). $\mathrm{Zn}$-nuclear, micro $\mathrm{Fe} / \mathrm{Cu}$ and micro $\mathrm{Zn} / \mathrm{Cu}$ exhibit wrinkled aspect while the remaining particles show a smooth aspect.

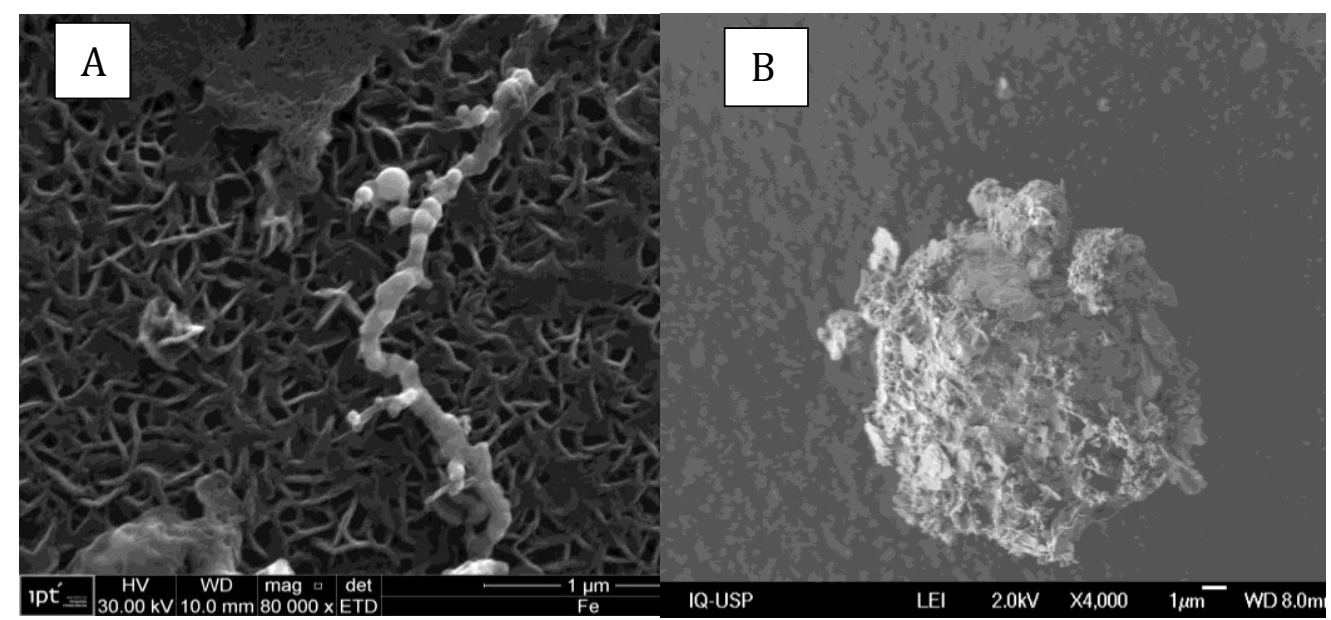

Figure 35. (A) SEM-FEG image $[\times 50,000]$ of nZVI; (B) SEM-FEG image $[\times 4,000]$ of $\mathrm{Zn} / \mathrm{Cu}$. 

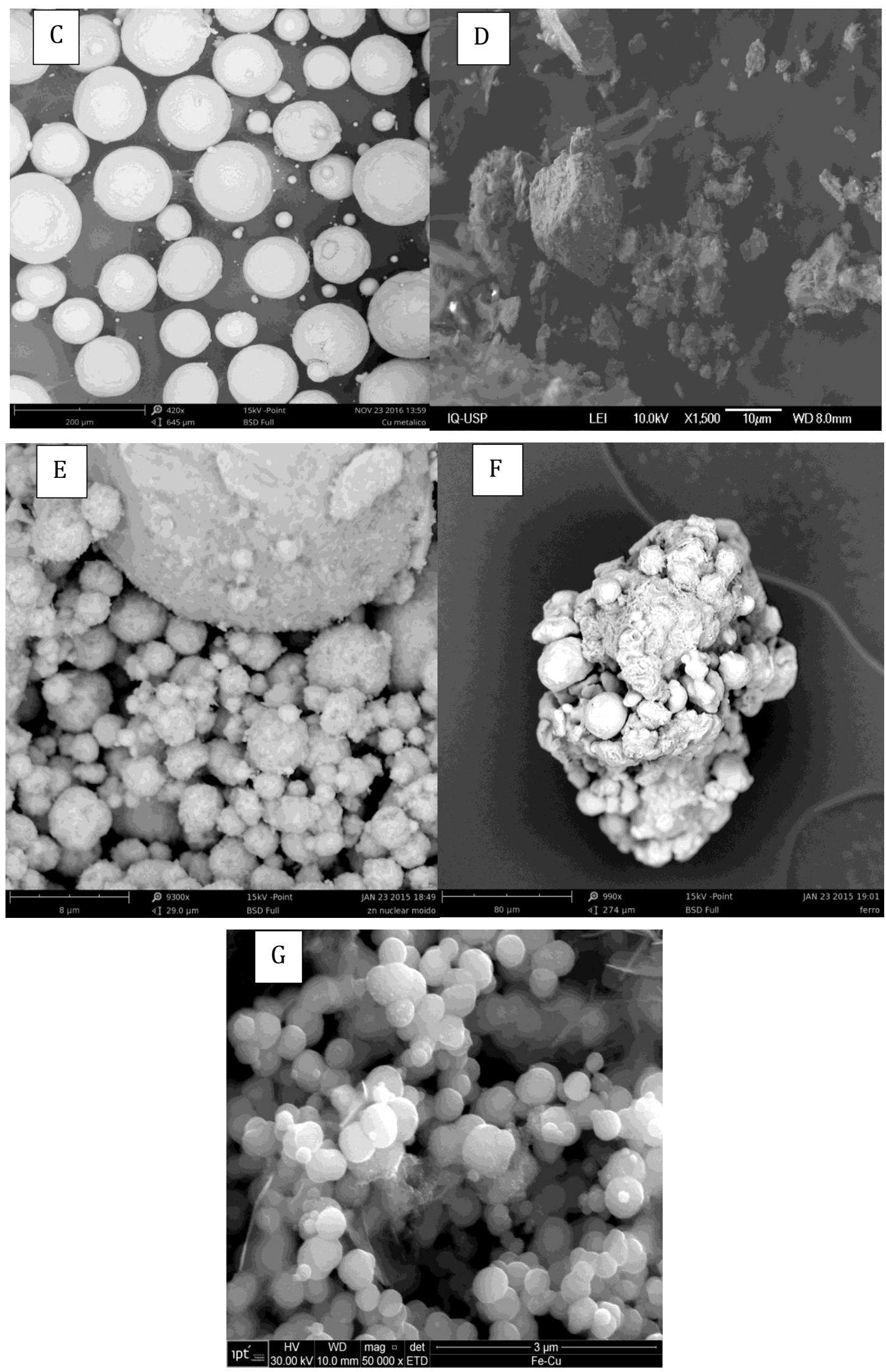

Figure 35 (cont.). (C) SEM-FEG image $[\times 1,500]$ of micro $\mathrm{Fe} / \mathrm{Cu}$; (D) SEM-EDS image $[\times 420]$ of $\mathrm{Cu}^{0}$; (E) SEM-EDS image $[\times 9300]$ of $\mathrm{Zn}^{0}$; (F) SEM-EDS image $[\times 990]$ of micro ZVI; $(\mathrm{G})$ SEM-FEG image $[\times$ $50,000]$ of $\mathrm{nZVI} / \mathrm{Cu}^{0}$. 
Since the specific surface area of particles is essential to explain the reactive behavior and is necessary for comparing materials of different compositions, the BET analysis was performed for all the studied materials and the corresponding results are shown at Table 16. In the case of nanoparticles an attempt was made to perform BET analysis by previously drying the materials in a vacuum oven purged with $\mathrm{N}_{2}$; nevertheless nanoparticles are known to be very reactive to oxygen, and even trying to ensure an inert atmosphere during the drying process, a much higher area than that reported was observed $\left(137.6 \mathrm{~m}^{2} \mathrm{~g}^{-1}\right.$ in the case of $\mathrm{nZVI} / \mathrm{Cu}$ ), which might be a result of particles oxidation. Therefore, for the nanomaterials we report here the values found by the researchers whose methodology for nanoparticles synthesis was followed. As can be observed, higher specific surface areas are associated with smaller particles and/or bimetallic particles, as expected, since the last ones reveal wrinkled surfaces and smaller particles have higher specific surfaces.

Table 16. Particles size based on SEM images and specific surface areas obtained from BET analysis.

\begin{tabular}{lcc}
\hline Material & Size range & $\begin{array}{c}\text { BET surface area } \\
\left(\mathbf{m}^{\mathbf{2}} \mathbf{g}^{\mathbf{- 1}}\right)\end{array}$ \\
\hline Micro Fe & $16.2-204.6 \mu \mathrm{m}$ & 3.1 \\
\hline Micro Zn & $1.7-5.6 \mu \mathrm{m}$ & 2.7 \\
\hline Micro Cu & $35.5-132.4 \mu \mathrm{m}$ & 5.39 \\
\hline Micro Fe/Cu & $1.7-78.4 \mu \mathrm{m}$ & 11.6 \\
\hline Micro Zn/Cu & $0.36-147.2 \mu \mathrm{m}$ & 11.9 \\
\hline Nano Fe & $103-582 \mathrm{~nm}$ & $21.7 *$ \\
\hline Nano Fe/Cu & $148.6-1095.9 \mathrm{~nm}$ & $44.02^{* *}$ \\
\hline${ }^{*}$ data from (PONDER; DARAB; MALLOUK, 2000) \\
${ }^{* *}$ data from (ZIN et al., 2013)
\end{tabular}

The elemental composition of the nanoparticles was determined by EDS coupled to SEM and confirmed the composition of the monometallic and the bimetallic particles: $\mathrm{Fe}, \mathrm{Zn}$ or/and $\mathrm{Cu}$ (Figure 36, A-F). 


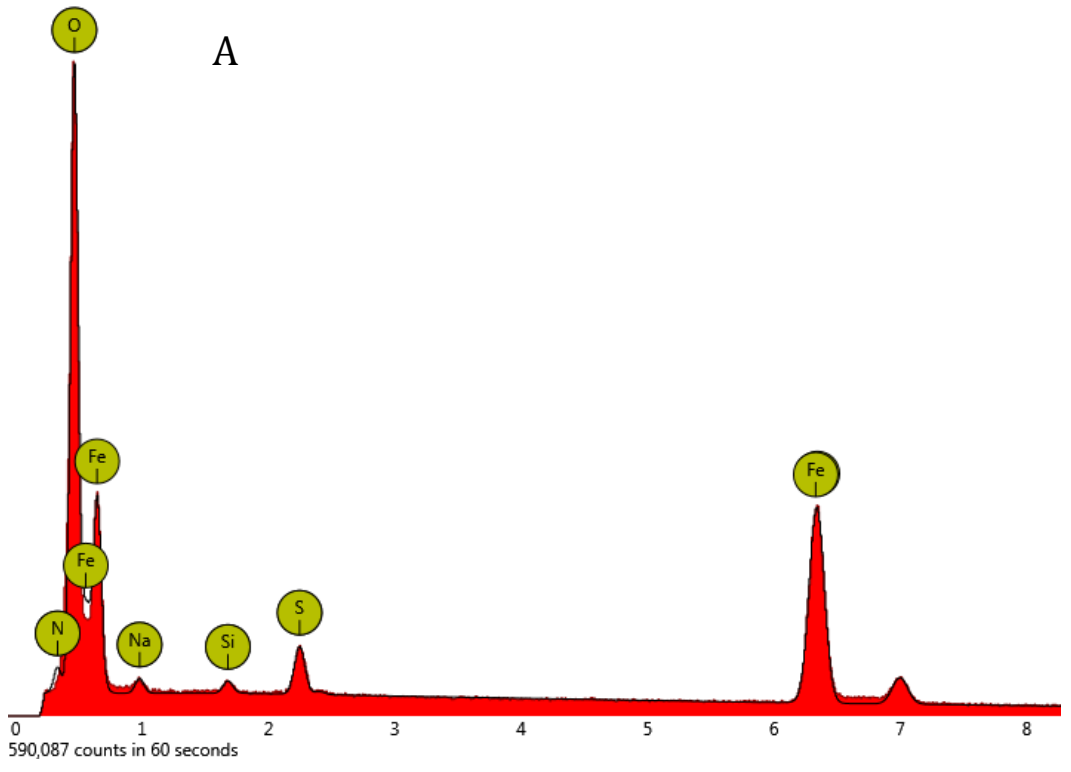

Full scale counts: $\mathbf{1 0 7 8}$

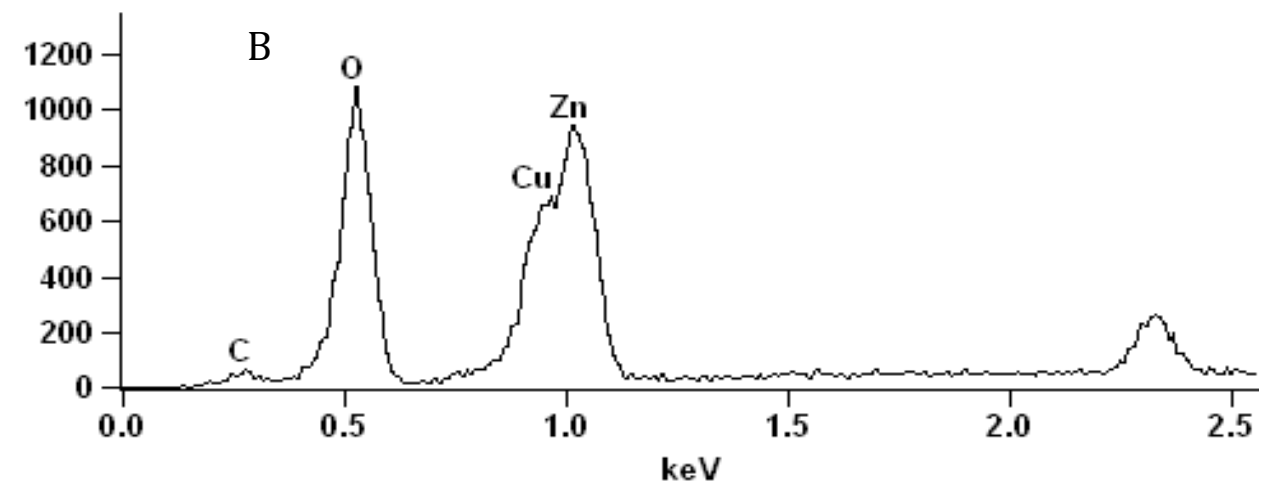

Full scale counts: 2231

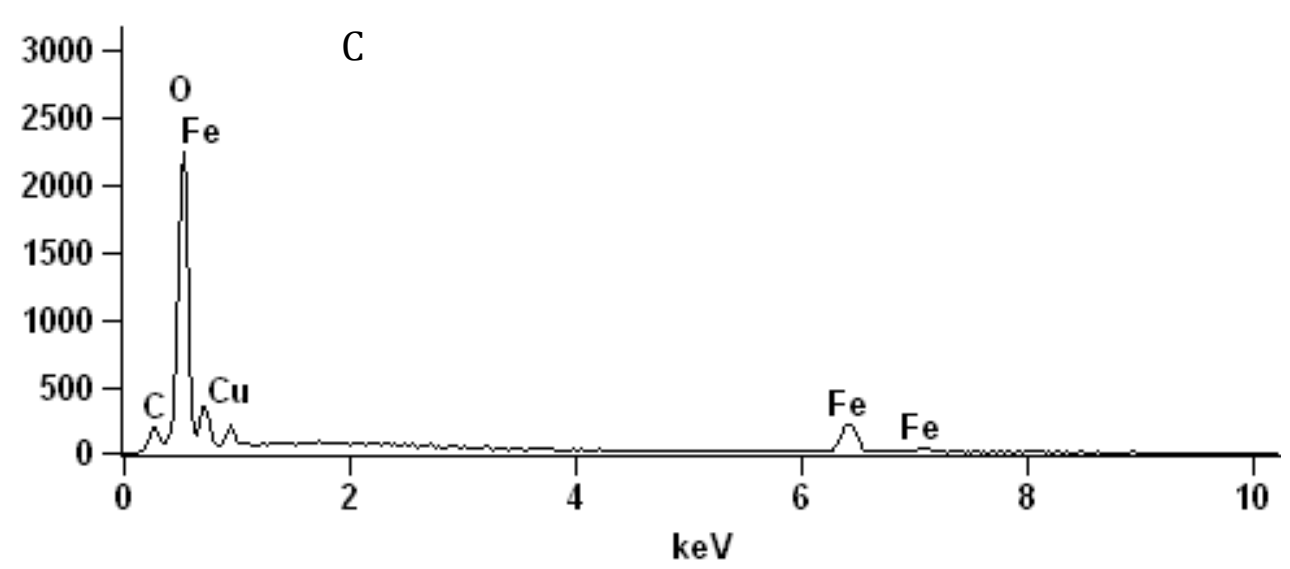

Figure 36. (A) EDS of nZVI; (B) EDS of Zn/Cu. (C) EDS micro ZVI/Cu. 


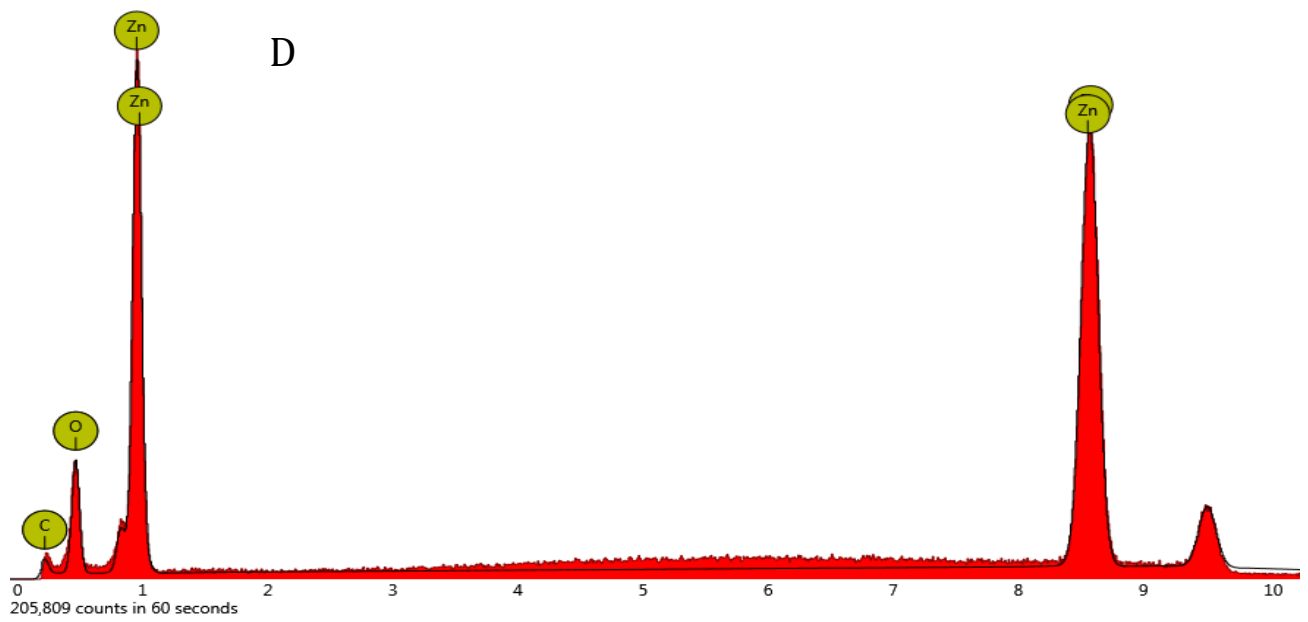

E
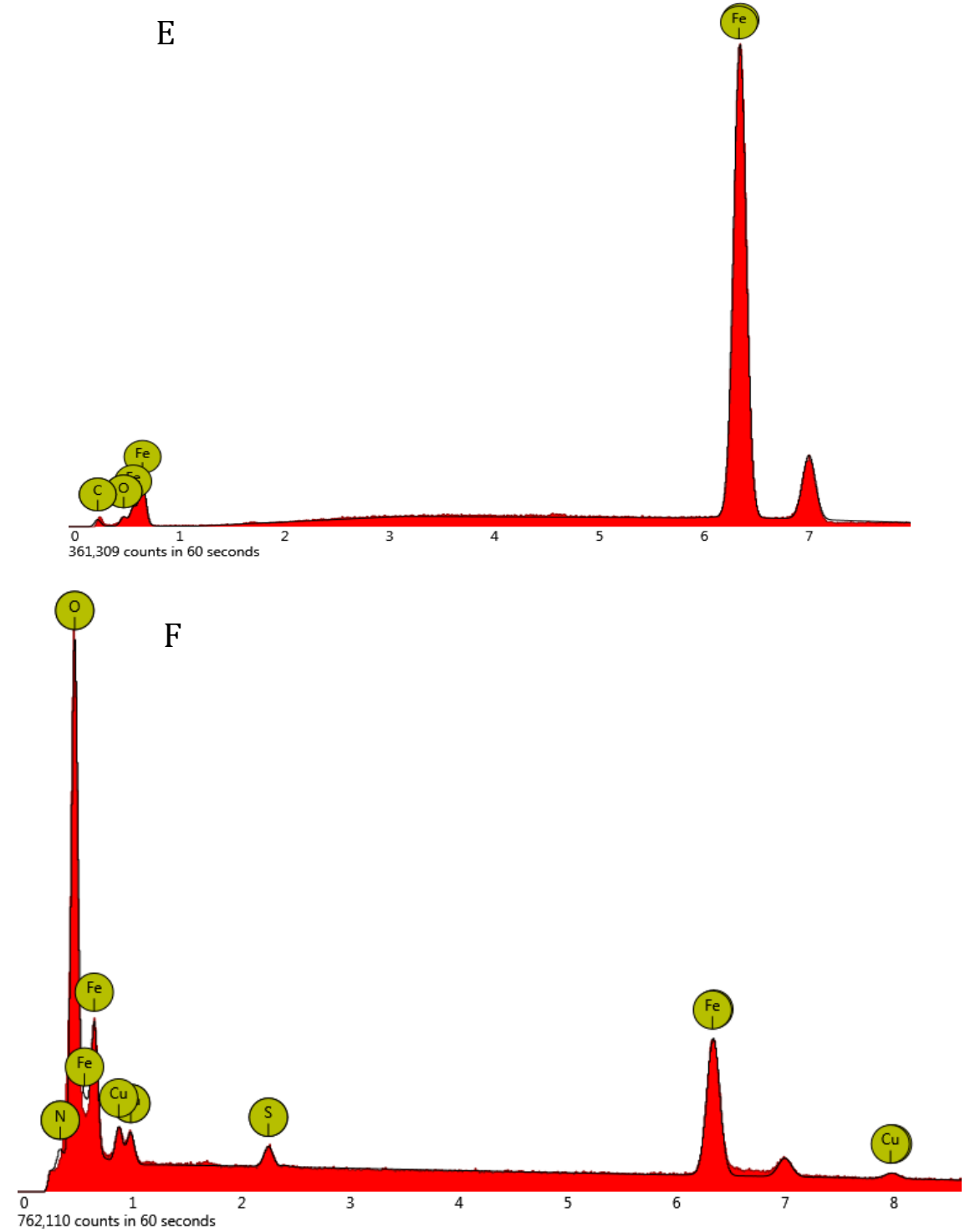

Figure 36 (cont.). (D) EDS of Zn ; (E) EDS micro ZVI; (F) EDS of nZVI/Cu.

XAS analysis confirmed that bimetallic particles contain zero-valent copper onto their surface, as well as some $\mathrm{Cu}$ (II). 
According to XDR analysis, synthesized nZVI and nZVI/Cu reveal amorphous structures, while the others obtained or synthesized through commercial metals reveal crystalline structures typical of $\mathrm{Fe}, \mathrm{Zn}$ or $\mathrm{Cu}$ phases accordingly (Figure 37, A-E), which were identified using the database of the International Center of Diffraction Data (ICDD) and the database provided by Rigaku.
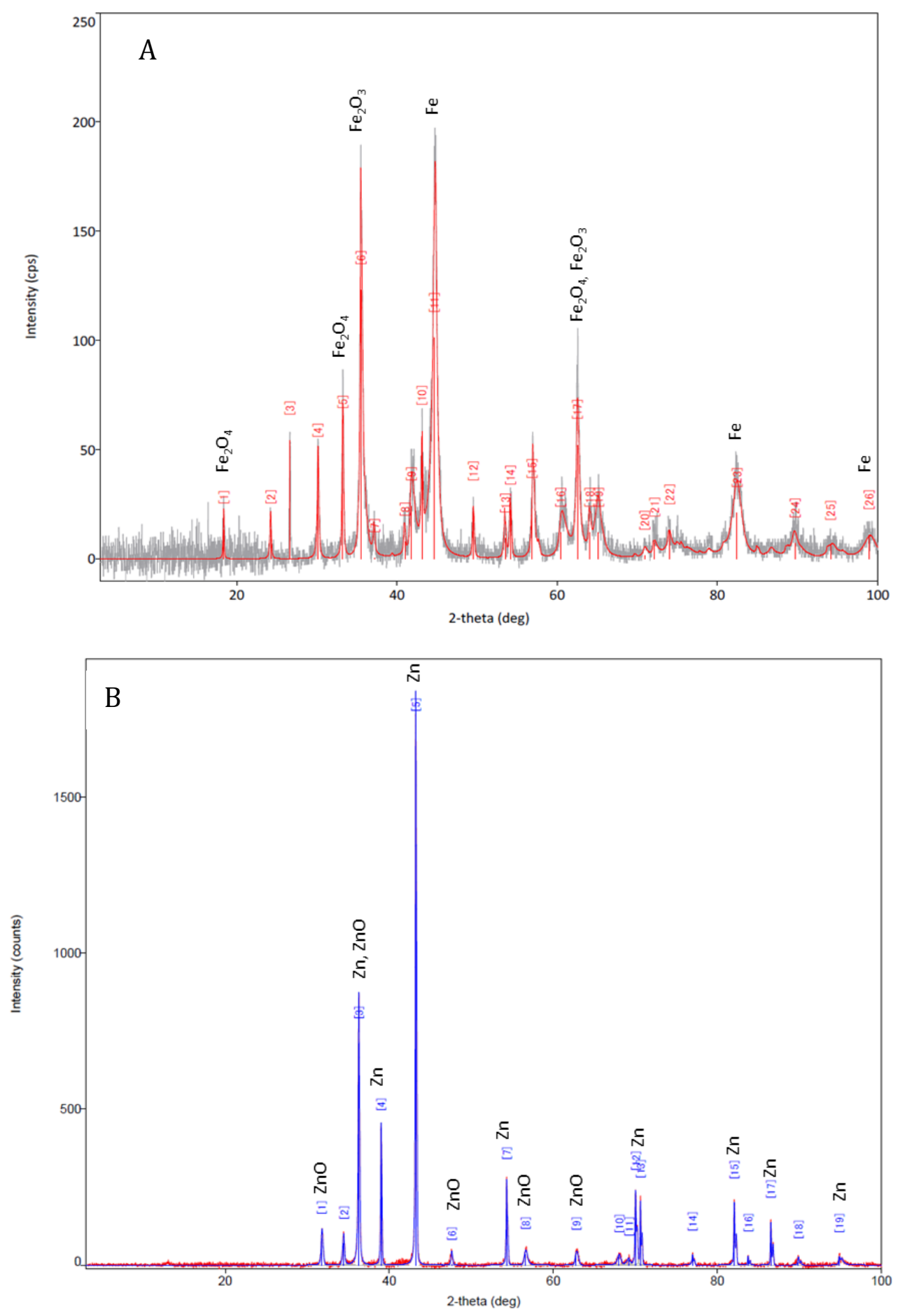

Figure 37. (A) micro ZVI diffractogram; (B) $\mathrm{Zn}^{0}$ diffractogram. 

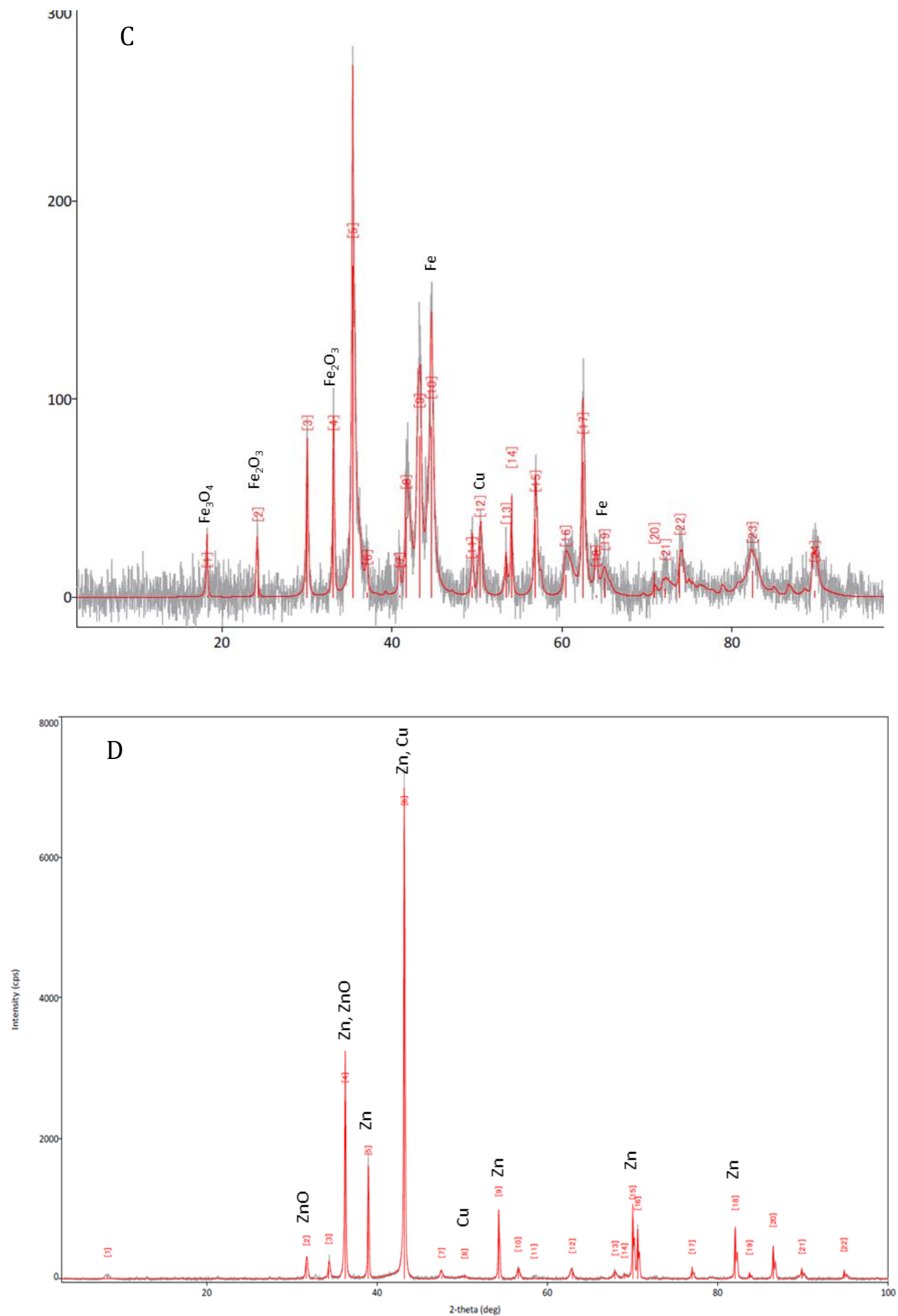

Figure 37 (cont.). (C) micro ZVI/Cu diffractogram; (D) Zn/Cu diffractogram; 


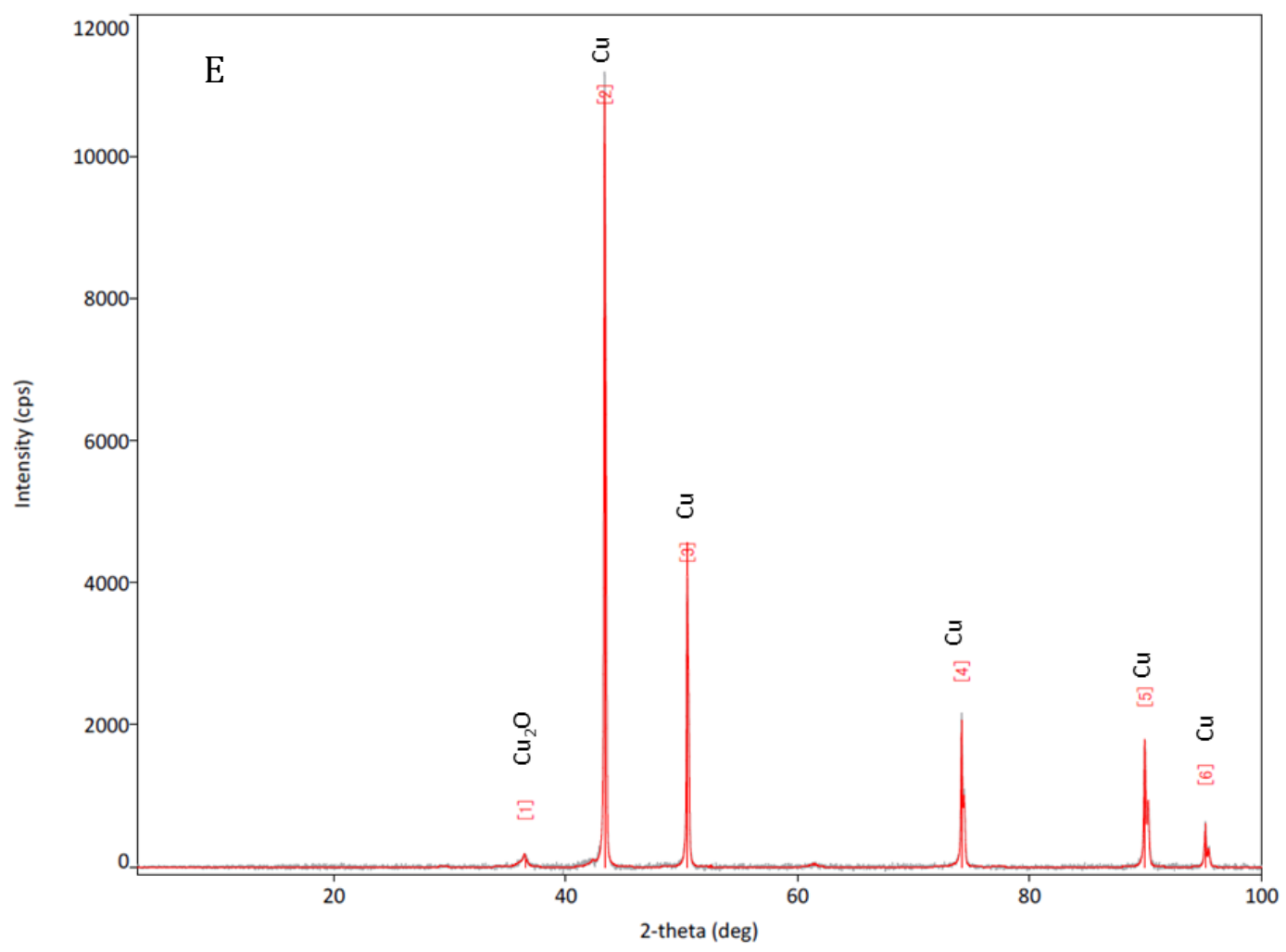

Figure 37 (cont.). (E) $\mathrm{Cu}^{0}$ diffractogram.

\subsubsection{Chlorpyrifos degradation}

\subsubsection{Influence of $\mathrm{nZVI}$ and $\mathrm{nZVI} / \mathrm{Cu}$ concentration}

Experiments with different nZVI and nZVI/Cu concentrations were conducted: first a trial with nZVI during a period of 18 days, in order to evaluate the influence of metal concentration on $\mathrm{CP}$ degradation rate and select the best one, then with $\mathrm{nZVI} / \mathrm{Cu}$ for 30 days. Concentrations of $0.25 \%, 0.5 \%$ and $1 \%(\mathrm{w} / \mathrm{V})$ were tested for $\mathrm{nZVI}$ and the results are shown in Figure 38A. No significant differences are observed in CP degradation rates for $\mathrm{nZVI}$ concentrations higher than $0.5 \%(\mathrm{w} / \mathrm{V})$. Control experiments in the absence of metal particles were also performed and revealed no significant $\mathrm{CP}$ degradation (blank control). Many researchers have concluded that the observed rate constant increased linearly with increased iron loading, although differing results like ours have also been reported in the literature (SHIH et al., 2015). These results can be due to particles aggregation, which is more likely to happen with high nZVI dosages, decreasing the available surface area for reaction (PHENRAT; SALEH, 2007). Therefore, the concentration of $0.5 \%(\mathrm{w} / \mathrm{V})$ was chosen to perform further experiments with different metals.

Experiments regarding the variation of $n Z \mathrm{VI} / \mathrm{Cu}$ concentration are shown in 
Figure 38B. Concentrations of $0.1 \%, 0.25 \%$ and $0.5 \%(\mathrm{w} / \mathrm{V})$ were chosen to perform these experiments in order to test concentrations below the optimal value found for nZVI. The results reveal that the increasing concentration led to higher CP removals at the end of 30 days. These results agree with previous studies regarding CP degradation with bimetallic nanoparticles, namely one where bimetallic $\mathrm{Fe} / \mathrm{Pd}$ particles immobilized in MgAlO support were used (NTHUMBI et al., 2016), suggesting that an increase in the number of particles leads to a proportional increase in the number of active sites and active surface area.

Comparing CP removals obtained with nZVI with those obtained with nZVI/Cu, it is clear that bimetallic particles are much more reactive, which was expected given the catalytic activity of $\mathrm{Cu}$. This result is consistent with others reporting enhanced nZVI reactivity by coating with noble metals (KIM; CARRAWAY, 2000; MORALES; HUTCHESON; CHENG, 2002; ZHANG; WANG; LIEN, 1998).

Previous studies proved that reductive dechlorination constitutes the major degradation process of CP by ZVI (REDDY et al., 2013). In order to verify this mechanism, chloride concentration was followed during 30 days of reaction for the metal particles concentration that promoted the highest degradation $(0.5 \% \mathrm{w} / \mathrm{V})$. The results shown in Figure 39 indicate that particles which promoted the highest degradation are the same which promoted the highest dechlorination, confirming that this mechanism makes part of the degradation process promoted by $\mathrm{nZVI/Cu}$, as well as by nZVI. However, these results also indicate that not all chlorine atoms are removed from the CP molecules (Figure 34) at the same time, otherwise a much higher chloride release would be observed. For example, in the case of $\mathrm{nZVI} / \mathrm{Cu}$, at the end of 30 days $90 \%$ of $\mathrm{CP}$ is degraded, which would correspond to a total chloride removal of $27 \mathrm{mg} \mathrm{L}^{-1}$; however only $3.28 \mathrm{mg} \mathrm{L}^{-1}$ was removed, indicating that degradation products still contain chlorine in their structures. 


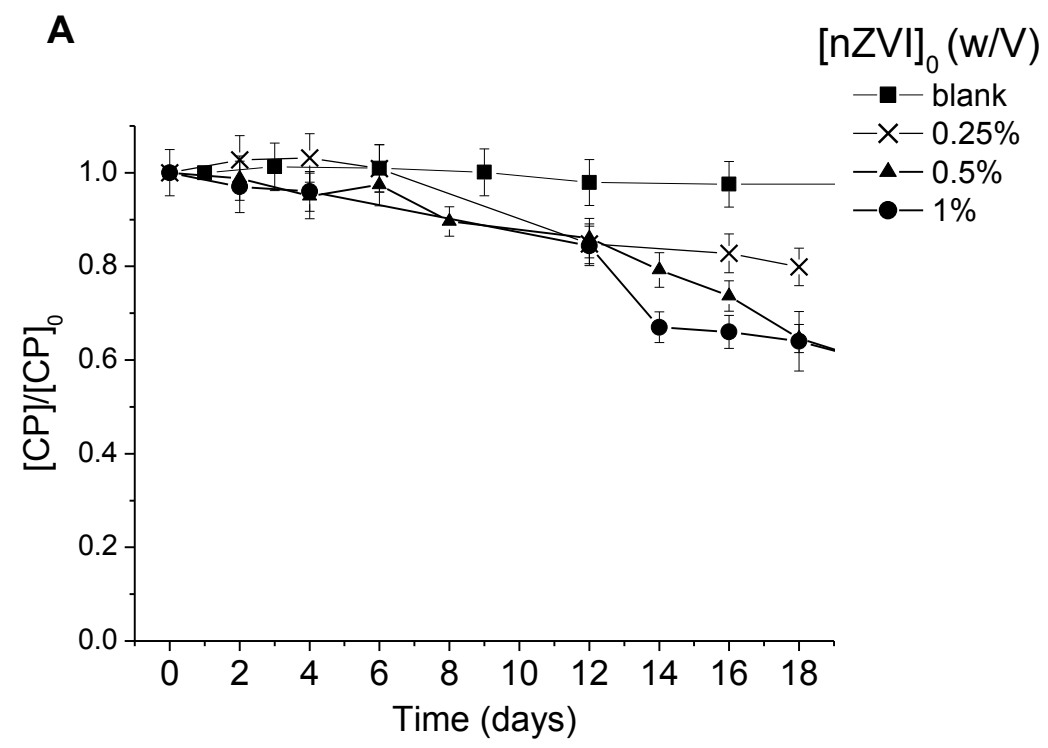

B

$[\mathrm{nZVI} / \mathrm{Cu}]_{0}(\mathrm{w} / \mathrm{V})$

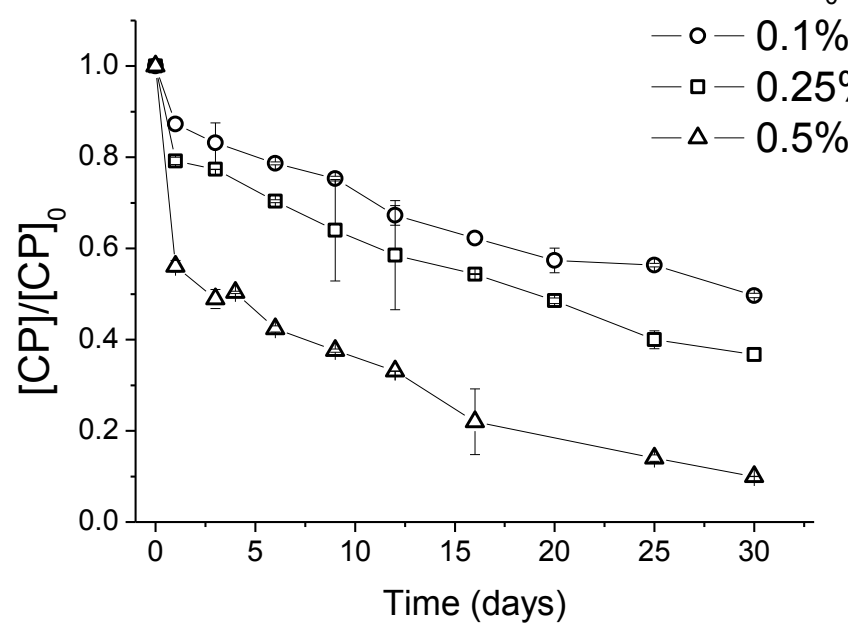

Figure 38. Effect of different (A) nZVI and (B) $n Z V I / C u$ concentrations on $\mathrm{CP}$ degradation. Conditions: $[\mathrm{CP}]_{0}=(100 \pm 10) \mathrm{mg} \mathrm{L}^{-1}$; free $\mathrm{pH}$.

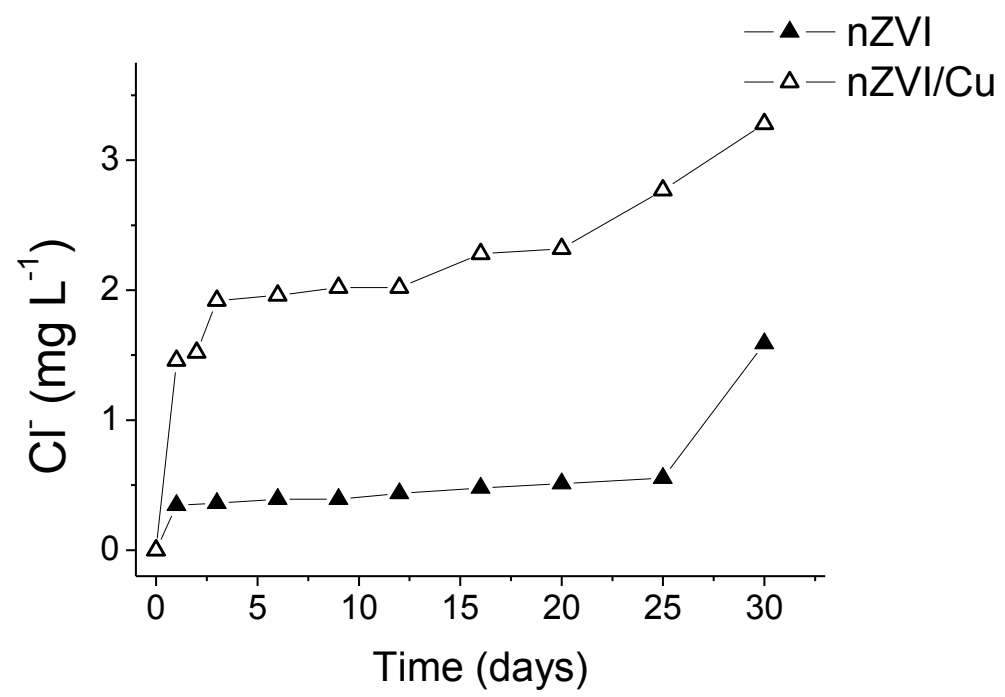

Figure 39. Chloride release as a result of $\mathrm{CP}$ dechlorination promoted by $\mathrm{nZVI}$ and $\mathrm{nZVI} / \mathrm{Cu}$. Conditions: $[\mathrm{CP}]_{0}=(100 \pm 10) \mathrm{mg} \mathrm{L}^{-1} ;[\mathrm{nZVI}]_{0}=[\mathrm{nZVI} / \mathrm{Cu}]_{0}=0.5 \%(\mathrm{w} / \mathrm{V})$, free $\mathrm{pH}$. 
11.2.2.2 Comparison between different monometallic and bimetallic microparticles

The effect of different metals, as well as the combination of these metals in bimetallic microparticles, was studied for $\mathrm{CP}$ degradation. The results are shown in Figure 40A and 40B, respectively.

Regarding monometallic microparticles, it is possible to observe that $\mathrm{Zn}^{0}$ particles promoted a higher $\mathrm{CP}$ degradation than $\mathrm{Fe}^{0}$. In this case, the effect of the standard reduction potential of the metal on $\mathrm{CP}$ degradation is more significant than that of available reactive sites (surface area): Zinc has a $\mathrm{E}_{\mathrm{H}}^{0} 1.73$ times smaller than $\mathrm{Fe}^{0}\left(\mathrm{E}_{\mathrm{Zn}}^{0}=\right.$ -0.762 V SHE; $\mathrm{E}_{\mathrm{Fe}}^{0}=-0.440 \mathrm{~V}$ SHE) (STEVEN G. BRATSCH, 1988), meaning that it donates electrons more easily and, therefore, has a greater ability to reduce chlorinated pesticides. However, this same factor does not explain the results obtained with $\mathrm{Cu}^{0}$, which promoted the fastest $\mathrm{CP}$ degradation (CP concentration below the quantification limit in $24 \mathrm{~h}$ ) and dechlorination (Figure 41), although revealing the highest standard reduction potential $\left(\mathrm{E}_{\mathrm{Cu}}^{0}=+0.339 \mathrm{~V} \mathrm{SHE}\right)(\mathrm{STEVEN} \mathrm{G}$. BRATSCH, 1988). This positive standard reduction potential of $\mathrm{Cu}^{0}$ reveals that this metal is very unlikely to provide electrons, raising the hypothesis that another degradation mechanism rather than electron transfer occurs with $\mathrm{Cu}^{0}$ particles.

Recent studies have used zero-valent copper particles in pollutants hydrodechlorination in the presence of a $\mathrm{H}_{2}$ source, as $\mathrm{BH}_{4}^{-}$(BELAY et al., 2015; HUANG; LO; LIEN, 2012), since copper is known to be a strong hydrogenation catalyst. However, in the absence of $\mathrm{H}_{2}$ and under anaerobic conditions, zero-valent copper and ZVI have shown similar efficiencies in chlorobenzene reduction (LEE; JOU; WANG, 2010), thus similar results would be expected in our study. However, a new approach regarding the dechlorination of contaminants containing aromatic rings in their structures by zero-valent copper was recently purposed by Duan et al. (2016). The authors suggested that the high degradation efficiency of copper is due to the conjugation between electron orbitals of $\mathrm{Cu}^{0}$ and large $\pi$-bonds of the aromatic ring present in the contaminant structure. This conjugation would explain electron transfer from copper to $\mathrm{CP}$, then promoting pesticide dechlorination. An evidence that confirms that copper acts as electron donner is the high content of dissolved copper in solution after $24 \mathrm{~h}$ of reaction $\left(9 \mathrm{mg} \mathrm{L}^{-1}\right)$, indicating that during the degradation, $\mathrm{Cu}^{0}$ transforms into $\mathrm{Cu}$ (II) or $\mathrm{Cu}$ (I). In fact, $\mathrm{Cu}$ (II) can also act as a catalyst in $\mathrm{CP}$ hydrolysis, as reported by Mortland 
and Raman (1967). Here, $\mathrm{Cu}$ (II) binds to two sites of the CP molecule (nitrogen in the ring and sulfate on the phosphate side chain, see Figure 34), weakening the bonds and promoting hydrolysis, giving two main products: 3,5,6-trichloro-2-pyridinol (TCP) and diethylthiophosphate (DETP). In that same study the authors mentioned that TCP generation was monitored by following the appearance of a new peak at $320 \mathrm{~nm}$ on the $\mathrm{CP}$ absorbance spectrum. In fact, in our study all the HPLC chromatograms indicate a rising peak at $320 \mathrm{~nm}$ while the $290 \mathrm{~nm}$ peak decreases, indicating that TCP might have been produced by the time CP was degraded (see HPLC chromatograms in APPENDIX H). Given that, there are evidences in our results that TCP is one possible CP degradation product. Other investigation where $\mathrm{CP}$ reductive degradation pathway was studied also indicated TCP as one of the main intermediates (REDDY et al. 2013). To confirm this conjecture, degradation intermediates must be identified, which was performed and discussed ahead in this study.

Furthermore, monometallic copper revealed much higher degradation and dechlorination efficiency than bimetallic particles containing copper onto their surfaces. As aforementioned, in bimetallic particles, copper is known to play a catalytic role rather than a reducing role, thus different degradation mechanisms are expected between these particles.

Comparing bimetallic and monometallic microparticles, copper clearly enhances ZVI and Zn reactivity, which can be addressed to the copper catalytic role in the bimetallic system, as suggested in the previous section. Again, the better performance of micro $\mathrm{Zn} / \mathrm{Cu}$ in relation to micro $\mathrm{ZVI} / \mathrm{Cu}$ is attributed to the differences in standard reduction potentials: in bimetallic systems, the electron donor and $\mathrm{H}_{2}$ supplier is the primary metal, so the smaller its standard reduction potential, the greater the electron transfer and generated $\mathrm{H}_{2}$, which is a feature assigned to $\mathrm{Zn}$.

Additionally, XAS investigations (data not shown) revealed the presence of both $\mathrm{Cu}^{0}$ and $\mathrm{Cu}(\mathrm{II})$ species in all bimetallic particles under study.

The amount of metal released during pesticide degradation is something that cannot be neglected, especially given the toxicity associated with $\mathrm{Zn}$ and $\mathrm{Cu}$ ions (MEHDINIA; SHEGEFTI; SHEMIRANI, 2015). The AAS analyses revealed greater amounts of dissolved iron and zinc than that observed for copper, $91 \mathrm{mg} \mathrm{L}^{-1}, 100 \mathrm{mg} \mathrm{L}^{-1}$ and $11.8 \mathrm{mg} \mathrm{L}^{-1}$, respectively, after 30 days of reaction. These concentrations are higher 
than those allowed in drinking water $\left(<2 \mathrm{mg} \mathrm{L}^{-1}\right)$, according to the limits proposed by the World Health Organization (WHO, 2011), which may raise concerns regarding ZVM field application. Nevertheless, given its high reactivity, smaller amounts of copper than that applied in our studies could be used, in order to meet safety standards. Also, CP concentrations found in natural waters are usually below $0.1 \mu \mathrm{g} \mathrm{L}^{-1}$ in surface waters or $0.01 \mu \mathrm{g} \mathrm{L}^{-1}$ in ground waters (WHO, 2011), thus probably requiring a much lower copper amount for degradation. All these aspects together, in addition to the metal cost and availability, have to be considered when selecting the most appropriate ZVM for practical applications. Given that, zero-valent copper appears to be the most suitable metal among all the metals studied.
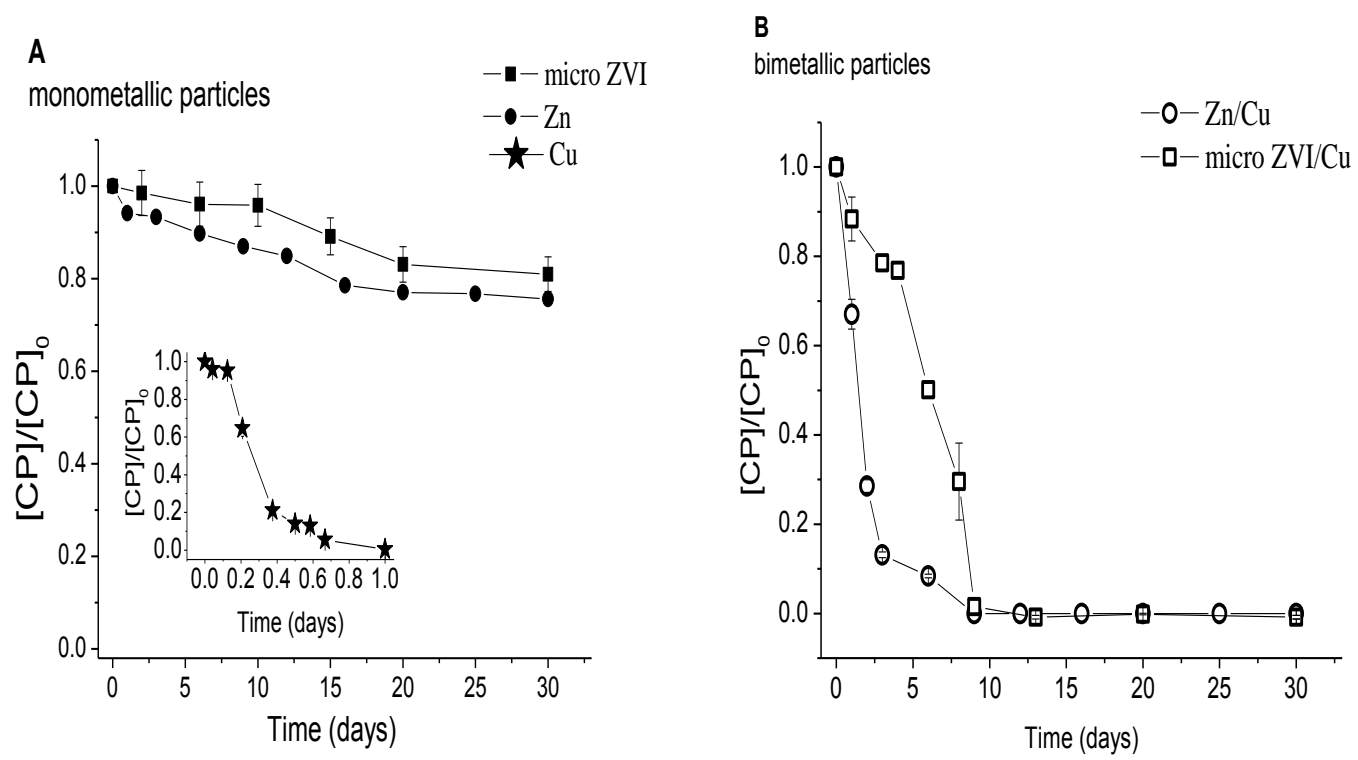

Figure 40. Comparison between the effect of different (A) monometallic and (B) bimetallic particles on $\mathrm{CP}$ degradation. Conditions: $[\mathrm{CP}]_{0}=(100 \pm 10) \mathrm{mg} \mathrm{L}^{-1}$; metals initial concentration $=0.5 \%(\mathrm{w} / \mathrm{V})$; free $\mathrm{pH}$.

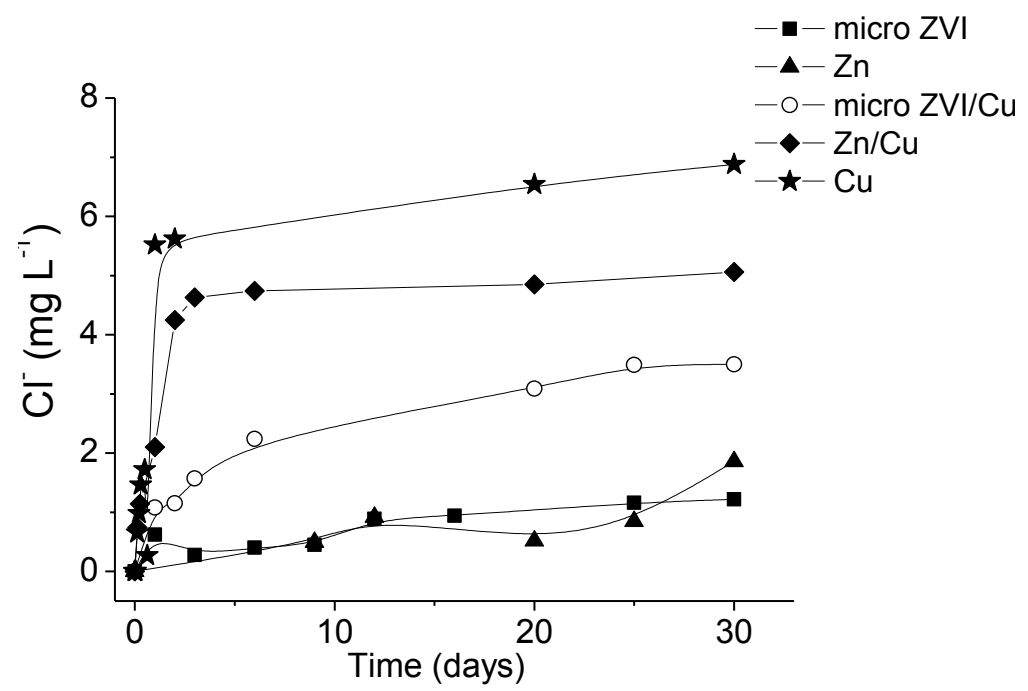

Figure 41. Chloride release as a result of $\mathrm{CP}$ dechlorination promoted by monometallic and bimetallic microparticles. Conditions: $[\mathrm{CP}]_{0}=(100 \pm 10) \mathrm{mg} \mathrm{L}^{-1}$; metals initial concentration $=0.5 \%(\mathrm{w} / \mathrm{V})$, free $\mathrm{pH}$. 
11.2.2.3 Determination of the observed degradation rate constant $\left(\mathrm{k}_{\mathrm{obs}}\right)$ and specific rate constant $\left(\mathrm{k}_{\mathrm{SA}}\right)$

All the anaerobic batch systems adjust to a pseudo-first-order rate model, except those performed with copper particles, which reveal two kinetic stages: a slower stage up to 3 hours followed by a faster one until complete degradation. However, an acceptable pseudo-first order kinetics fit was obtained for copper considering that the slower stage is due to particles adaptation to the medium and the degradation effectively starts after that. Actually, ahead in this study, this hypothesis is supported by pre-exposure experiments. Given that, to facilitate the comparison between particles reactivity in terms of rateconstants, the slower stage was not considered in the calculation of observed CP degradation rate constants $\left(k_{\mathrm{obs}}\right)$ promoted by copper particles (Figure 42 ).

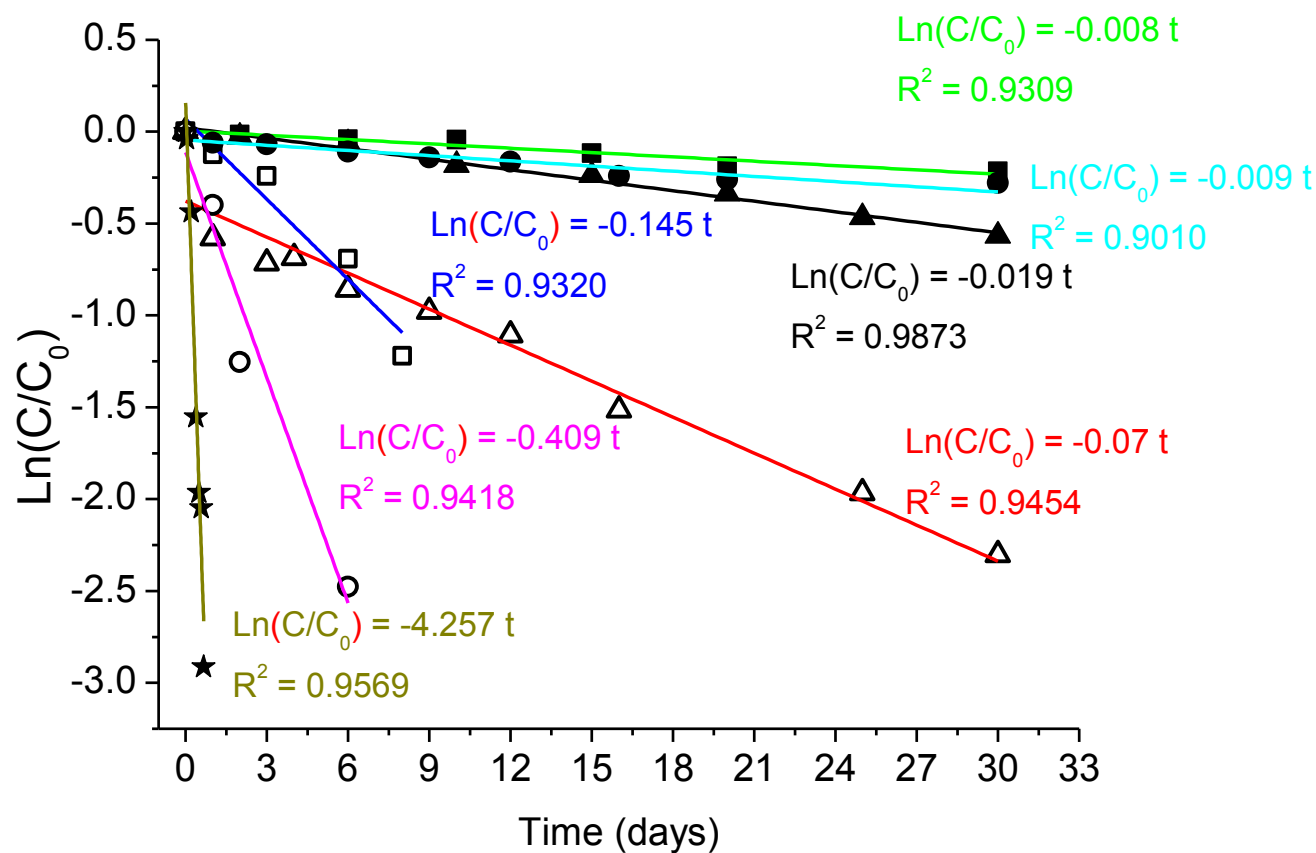
- micro ZVI
$\Delta$ - nZVI
- $\mathrm{Zn} \quad$ - Zn fitting
$\square$ - micro ZVI/Cu - micro ZVI/Cu fitting
$\Delta-\mathrm{nZVI} / \mathrm{Cu}-\mathrm{nZVI} / \mathrm{Cu}$ fitting
$\mathrm{O} \mathrm{Zn} / \mathrm{Cu}-\mathrm{Zn} / \mathrm{Cu}$ fitting
$\star \mathrm{Cu} \quad-\mathrm{Cu}$ fitting

Figure 42. First-order kinetic fitting for $\mathrm{CP}$ degradation. Conditions: $[\mathrm{CP}]_{0}=100 \mathrm{mg} \mathrm{L}^{-1}$; metals initial concentration $=0.5 \%(\mathrm{w} / \mathrm{V})$, free $\mathrm{pH}$.

According to Johnson; Scherer and Tratnyek (1996) first-order degradation rate constants $\left(k_{\text {obs }}\right)$ normalized with respect to the particle specific surface area offers a more realistic description of contaminant degradation kinetics. Therefore, in our results this same procedure was followed in order to compare metals reactivity in a more realistic way. Specific rate constants for each metal $\left(k_{\mathrm{SA}}, \mathrm{L}\right.$ day $\left.{ }^{-1} \mathrm{~m}^{-2}\right)$ were then calculated according to Eq. 37: 
$\mathrm{k}_{\mathrm{SA}}=\frac{\mathrm{k}_{\mathrm{obs}}}{\rho_{\mathrm{m}} a_{\mathrm{s}}}$

Where $k_{\mathrm{obs}}$ is the observed rate constant, $\rho_{\mathrm{m}}$ is the mass concentration of metal $\left(\mathrm{g} \mathrm{L}^{-1}\right)$ and $a_{\mathrm{s}}$ is the specific surface area of metal $\left(\mathrm{m}^{2} \mathrm{~g}^{-1}\right)$. Results are shown in Table 17.

Table 17. Average $k_{\mathrm{obs}}$ and $k_{\mathrm{SA}}$ values calculated for each metal studied at $0.5 \mathrm{~g} \mathrm{~L}^{-1}$.

\begin{tabular}{llc}
\hline Metals & $\begin{array}{c}k_{\text {obs }} \\
\left(\text { days }^{-1}\right)\end{array}$ & $\left(\mathrm{L} \mathrm{day}^{-1} \mathrm{~m}^{-2}\right)$ \\
\hline Micro ZVI & 0.008 & $5.1 \times 10^{-4}$ \\
$\mathrm{Zn}$ & 0.009 & $6.8 \times 10^{-4}$ \\
$\mathrm{Cu}$ & 4.257 & 0.158 \\
$\mathrm{micro} Z \mathrm{ZVI} / \mathrm{Cu}$ & 0.143 & $2.4 \times 10^{-3}$ \\
$\mathrm{Zn} / \mathrm{Cu}$ & 0.43 & $7.2 \times 10^{-3}$ \\
$\mathrm{nZVI}$ & 0.019 & $1.8 \times 10^{-4}$ \\
$\mathrm{nZVI} / \mathrm{Cu}$ & 0.07 & $2.7 \times 10^{-4}$ \\
\hline
\end{tabular}

Results show that bimetallic particles promote higher CP $k_{\text {obs }}$ than monometallic particles, which is valid for $\mathrm{nZVI} / \mathrm{Cu}$ in comparison with $\mathrm{nZVI}$, micro ZVI/Cu with micro $\mathrm{ZVI}$ and $\mathrm{Zn} / \mathrm{Cu}$ with $\mathrm{Zn}^{0}$. Researches where the dechlorination of several chlorinated aliphatics and aromatics was studied using different bimetals (BRANSFIELD; CWIERTNY; ROBERTS, 2006; CHOI; KIM, 2009; LIEN; ZHANG, 2005; ZHANG; WANG; LIEN, 1998) report similar behavior, in comparison to the monometallic particles used in the same studies.

Another factor that can contribute to the faster degradation observed with bimetallic particles is their specific surface area, which was always higher than that obtained for monometallic particles used in their synthesis. However, this factor alone does not explain the significant differences observed between their $k_{\mathrm{SA}}$, suggesting that another effect apart from the surface area is enhancing bimetallic particles reactivity. For that reason, catalytic effects of $\mathrm{Cu}^{0}$ and $\mathrm{Cu}$ (II) together with high surface areas are plausible reasons for the faster pesticide degradation obtained with bimetallic systems. 
Comparing monometallic particles from the same metal (nZVI vs. micro ZVI), it is possible to conclude that smaller particles achieved higher $k_{\text {obs }}$ values, as expected, since they have higher surface areas, resulting in higher reactivity. However, there is a significant difference between their $k_{\mathrm{SA}}$ values. These differences in $k_{\mathrm{SA}}$ between monometallic iron particles can rely in differences between metals internal structures, since the nano-sized ZVI synthesized in this study reveals amorphous structure (confirmed by DRX), while micro-sized ZVI reveals crystalline structure (Figure 37A), explaining the higher reactivity, in terms of $k_{\mathrm{SA}}$, achieved with the latter.

11.2.2.4. Influence of previous surface treatment of the particles

Some particles revealed a stagnation phase at the beginning of the reaction before $\mathrm{CP}$ concentration started decreasing. This behavior was more evident with copper particles, where degradation started abruptly after 5 hours. The other monometallic micro-sized particles revealed a similar stagnation period during the first days of reaction. Similar results were obtained by Tratnyek et al. (2010), where a lag phase up to $6 \mathrm{~h}$ was observed for zinc particles before the $\mathrm{CCl}_{4}$ reduction started, due to the existence of passive oxide films around the $\mathrm{Zn}$ particles. In this same study the authors suggested that the lag phase can be avoided by pre-exposing the particles to the medium before adding the contaminant, thus skipping the time needed to breakdown the passive films. Given that, we performed a trial test to evaluate the influence of pre-exposing copper particles during $24 \mathrm{~h}$ in the reaction medium before adding CP. As shown in Figure 43, preexposed particles revealed higher reactivity than non-exposed particles, starting to degrade CP right after one hour of reaction, confirming that pre-exposition avoids the initial lag phase. This result helps to support our prior hypothesis that $\mathrm{Cu}(\mathrm{II})$ catalyzes $\mathrm{CP}$ hydrolysis when released during the reaction. By pre-exposing copper particles to the medium, by the time $\mathrm{CP}$ is added there is already a certain amount of solubilized $\mathrm{Cu}$ (II) available to hydrolyze the pesticide. 


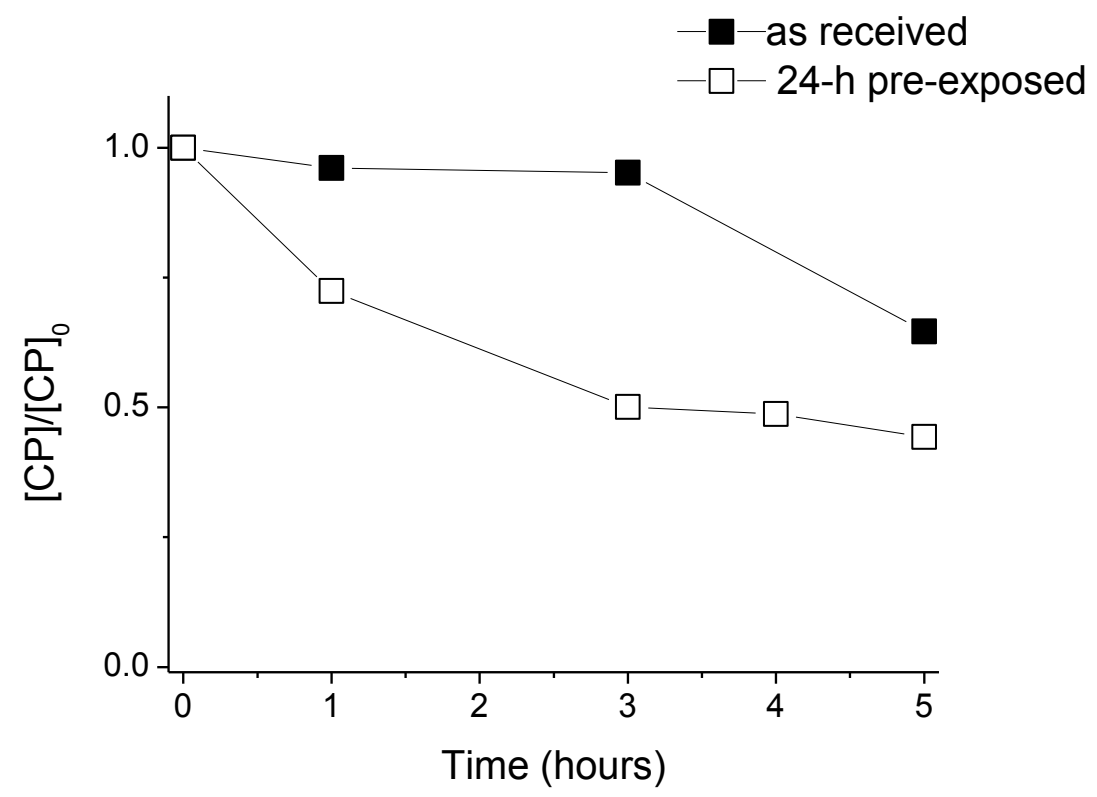

Figure 43. Influence of the pre-exposure of copper particles to the reaction medium on $\mathrm{CP}$ degradation. Conditions: $[\mathrm{CP}]_{0}=(100 \pm 10) \mathrm{mg} \mathrm{L}^{-1}$; metals initial concentration $=0.5 \%(\mathrm{w} / \mathrm{V})$; free $\mathrm{pH}$.

Iron and Zinc are known to readily oxidize when exposed to air, so probably the slow degradation promoted by these micro sized particles is due to the presence of oxides onto their surface, which are known to compromise their overall activity (FORSBERG; PENN; KIM, 2010). XRD analyses confirm the presence of iron and zinc oxides in micro ZVI and Zn particles, respectively (Figures 44A and 44B). Previous studies proved that this passive layer can be removed by acid washing (JOHNSON; SCHERER; TRATNYEK, 1996). For that reason, a 15-day trail test with iron and zinc particles previously washed with $\mathrm{H}_{2} \mathrm{SO}_{4} 0.4 \%$ (v/v) was performed. As can be observed in Figures $44 \mathrm{~A}$ and $44 \mathrm{~B}$ the acid washing of both particles significantly enhanced the initial $\mathrm{CP}$ degradation rate, suggesting that oxides onto particles surface were hampering the reaction. Similarly to the pre-treatment performed for $\mathrm{Cu}$ particles, a trial test where these particles were submersed in the reaction medium for $24 \mathrm{~h}$ prior to the addition of $\mathrm{CP}$ was also carried out, although no significant differences were observed in comparison to the reactions in which the particles were used as received. The lack of a notable increase in reaction rates upon prior medium exposure could be due to a high passivation layer on the surface of the untreated ZVI and Zn samples, increasing the time needed to observe the passive film breakdown. 

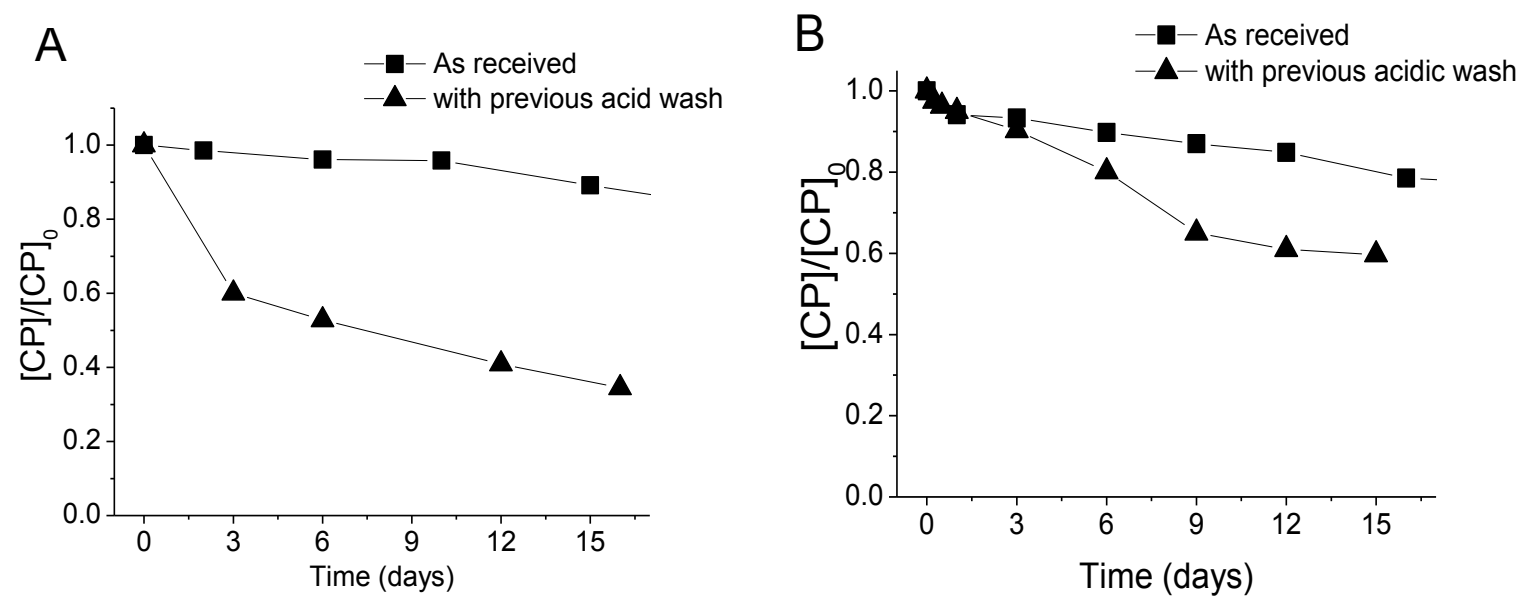

Figure 44. Influence of previous acid washing of (A) micro ZVI particles and (B) Zn particles on CP degradation. $[C P]_{0}=(100 \pm 10) \mathrm{mg} \mathrm{L}^{-1}$; metals initial concentration $=0.5 \%(\mathrm{w} / \mathrm{V})$; free $\mathrm{pH}$.

It is worth mentioning that bimetallic particles also involve an acid wash step during their synthesis and their XRD analyses still indicate the presence of oxides (Figure 37), which can be hampering their degradation efficiency.

11.2.2.5 Identification of chlorpyrifos degradation products by mass spectrometry

In other investigations dealing with $\mathrm{CP}$ degradation by zero-valent-metals, TCP and DETP were degradation products commonly identified (BOOTHARAJU; PRADEEP, 2012; REDDY et al., 2013), even resulting from different degradation mechanisms. As aforementioned, our results also suggest the formation of TCP during CP degradation due to the presence of a peak at $320 \mathrm{~nm}$ in all HPLC chromatograms, which is observed for all the metallic systems investigated. Also, both monometallic and bimetallic particles promoted CP dechlorination, therefore some degradation products with less chlorine in their structures than the parent-compound were expected. To confirm this conjecture, supernatants of the reaction mixture of $\mathrm{CP}\left(100 \mathrm{mg} \mathrm{L}^{-1}\right)$ and each metal $(0.5 \% \mathrm{w} / \mathrm{V})$, after a certain reaction time, were analyzed in a hybrid ion trap/time-offlight mass spectrometer, in order to assess the structural information of degradation products. Reaction times were selected to enable the detection of the highest number of degradation products possible, which were 6 days for ZVI, 30 days for ZVI/Cu, 16 days for $\mathrm{Zn}, 6$ days for $\mathrm{Zn} / \mathrm{Cu}$, and 9 hours for $\mathrm{Cu}$. These reaction times were chosen given their higher number of peaks on HPLC chromatogram, therefore increasing the chances of identifying more intermediates. The interpretation of mass spectrometry (MS) results is shown in Table 18 and the list of compounds assigned to each metal is shown in Table 19. 
Table 18. Mass spectrometry measurements $(\mathrm{m} / \mathrm{z})$ determined by LC/ESI(+)-IT-TOF and LC/ESI(-)-IT$\mathrm{TOF}$ of $\mathrm{CP}$ degradation products $(\mathrm{DBE}=$ Double bond equivalent $)$

\begin{tabular}{|c|c|c|c|c|c|c|}
\hline Identification & $\begin{array}{l}\text { HPLC } \\
\text { retention } \\
\text { time } \\
(\mathrm{min})\end{array}$ & Formula & Ion & $\begin{array}{l}\text { Experimental } \\
\text { mass-to- } \\
\text { charge ratio } \\
(\mathbf{m} / \mathbf{z})\end{array}$ & $\begin{array}{l}\text { Calculated } \\
\text { mass-to- } \\
\text { charge } \\
\text { ratio }(\mathbf{m} / \mathbf{z})\end{array}$ & DBE \\
\hline $\begin{array}{l}\text { A: O,O-diethyl O- }(3,5,6- \\
\text { trichloropyridin-2-yl) } \\
\text { phosphorothioate }\end{array}$ & 22.8 & $\begin{array}{l}\mathrm{C}_{9} \mathrm{H}_{11} \mathrm{NO}_{3} \mathrm{PSCl} \\
3 \\
\mathrm{C}_{9} \mathrm{H}_{11} \mathrm{NO}_{3} \mathrm{PSCl} \\
3\end{array}$ & $\begin{array}{l}{[\mathrm{M}+\mathrm{H}]^{+}} \\
{[\mathrm{M}+\mathrm{K}]^{+}}\end{array}$ & $\begin{array}{l}349.95 \\
390.29\end{array}$ & $\begin{array}{l}349.9336 \\
387.8894\end{array}$ & $\begin{array}{l}4.0 \\
4.0\end{array}$ \\
\hline $\begin{array}{l}\mathrm{B}: 3,5,6 \text {-trichloropyridin-2 } \\
\mathrm{Ol}\end{array}$ & 11.1 & $\mathrm{C}_{5} \mathrm{H}_{2} \mathrm{NOCl}_{3}$ & {$[\mathrm{M}-\mathrm{H}]^{-}$} & 195.916 & 195.9129 & 3.0 \\
\hline C: Phosphorothioic acid & 11.85 & $\mathrm{H}_{6} \mathrm{O}_{6} \mathrm{P}_{2} \mathrm{~S}_{2}$ & {$[\mathrm{M}-\mathrm{H}]^{-}$} & 112.991 & 112.9468 & 2.0 \\
\hline
\end{tabular}

\begin{tabular}{llllll}
\hline $\begin{array}{l}\text { D: O-(4-chloropyridin-2- } \\
\text { yl) phosphinothioate }\end{array}$ 10.6 & $\mathrm{C}_{5} \mathrm{H}_{5} \mathrm{NOPSCl}$ & {$[\mathrm{M}-\mathrm{H}]^{-}$} & 191.965 & 191.9445 & 4.0 \\
yl) O-ethyl O-methyl \\
phosphorothioate
\end{tabular}


Table 18 (cont.). Mass spectrometry measurements (m/z) determined by LC/ESI(+)-IT-TOF and LC/ESI(-)-IT-TOF of CP degradation products. (DBE = Double bond equivalent).

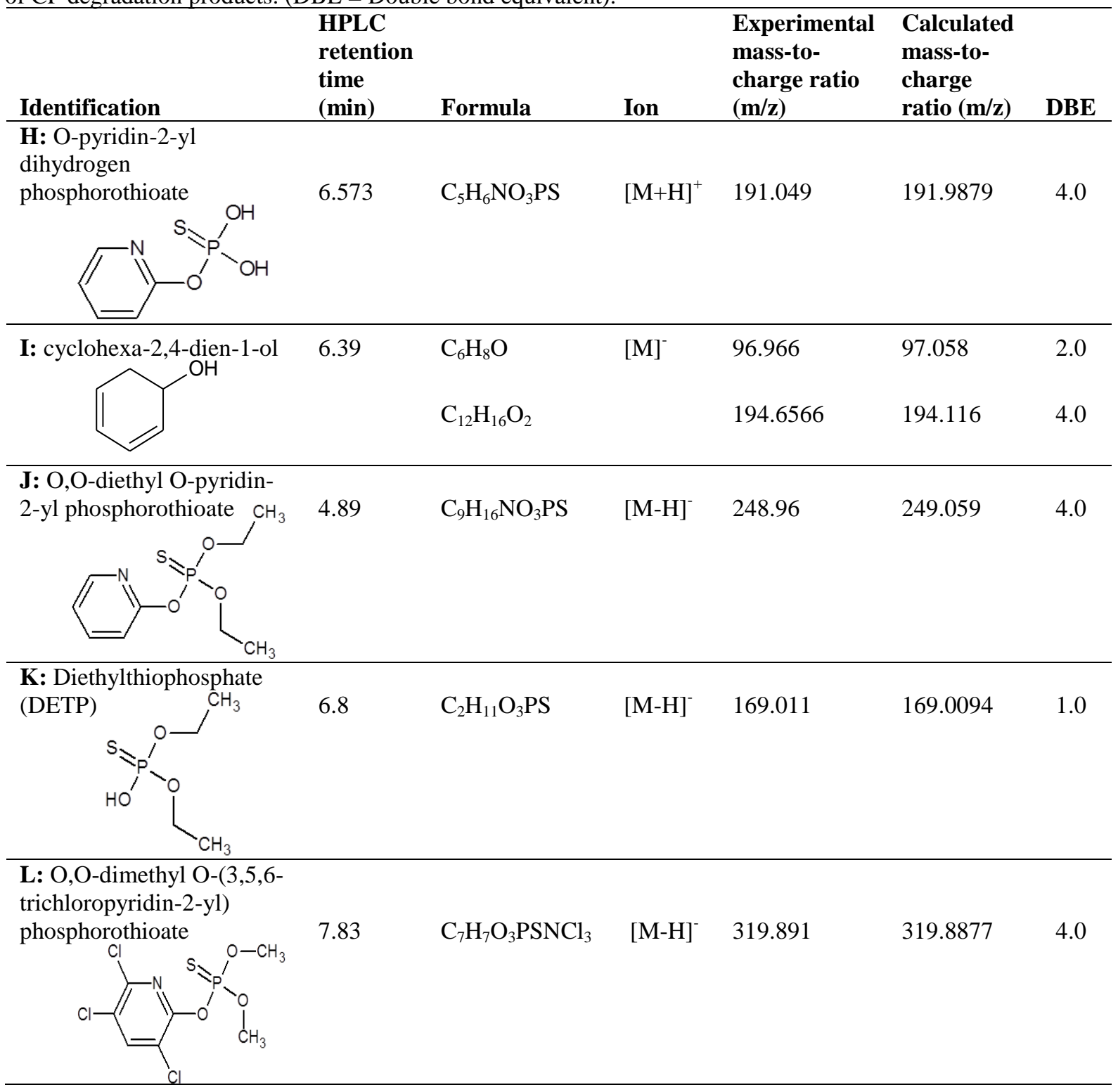

Table 19. Identified products for each metal tested.

\begin{tabular}{ll}
\hline Metal & Identified products \\
\hline $\mathbf{Z V I}$ & B, C, F, I, J, K \\
\hline $\mathbf{Z V I} / \mathbf{C u}$ & B, C, F, J, K \\
\hline $\mathbf{Z n}$ & B, C, F, J, K, L \\
\hline $\mathbf{Z n} / \mathbf{C u}$ & B, C, H, J, K \\
\hline $\mathbf{C u}$ & A, B, D, E, G, H, K
\end{tabular}

As can be observed, mass spectrometry analyses confirm that TCP and DETP are common degradation products to all metallic systems, which is in accordance to previous studies regarding CP degradation via zero-valent metals. Degradation products identified in Table 3 as C, G and I were also identified by Reddy et al. (2013) in a study regarding $\mathrm{CP}$ degradation by ZVI in soils. Product $\mathrm{C}$ was proposed by those authors to be derived 
from DETP, while products $\mathrm{G}$ and I derived from TCP dechlorination. In our study product $\mathrm{G}$ appeared for $\mathrm{Cu}$-induced degradation and product $\mathrm{I}$ for ZVI-induced degradation, indicating that these systems also promoted $\mathrm{CP}$ dechlorination by first breaking the CP molecule into TCP and DETP and then dechlorinating TCP. ZVI, $\mathrm{ZVI} / \mathrm{Cu}$ and $\mathrm{Zn}$ reveal the product $\mathrm{F}$ in common, indicating that they promoted ring breakage of product $\mathrm{G}$ in some point of the degradation mechanism. Product $\mathrm{J}$ is also a common compound found in all the solutions analyzed, including the solution prior to degradation. This compound might have undergone hydrolysis, giving non-chlorinated compounds, such as $\mathrm{K}, \mathrm{I}, \mathrm{H}$ and $\mathrm{C}$, which prevents to associate these compounds to $\mathrm{CP}$ reductive dechlorination products.

Degradation promoted by Zn-containing particles might exhibit a different degradation pathway compared to that reported by Reddy et al. (2013) for ZVI particles, since different degradation products not derived from TCP were here identified, namely products $\mathrm{L}$ and $\mathrm{H}$. Product $\mathrm{L}$ results from the loss of two $-\mathrm{CH}_{3}$ from $\mathrm{CP}$. If $\mathrm{Zn}$ continues degrading this molecule, promoting the loss of two more methyl groups and then dechlorinating it, it gives raise to product $\mathrm{H}$. Notwithstanding, TCP and DETP are also identified, thus the "traditional" degradation mechanism can be occurring simultaneously.

Products $\mathrm{D}$ and $\mathrm{E}$ were never identified before and appear only during the degradation promoted by $\mathrm{Cu}$ particles. These can be originated from the loss of one $-\mathrm{CH}_{3}$ from $\mathrm{CP}$ and subsequent dechlorination. It is worth mentioning that these products might not have been identified in other metallic system due to differences in the degradation stage. However, similarly to what was mentioned for the $\mathrm{Zn}$-induced degradation, these products indicate a different degradation mechanism from that reported for ZVI particles (REDDY et al. 2013), since they cannot result from TCP dechlorination. By that, $\mathrm{Cu}$ particles might promote $\mathrm{CP}$ demethylation at the same time as its hydrolysis into TCP and DETP, then promoting subsequent dechlorination of molecules originated from these processes.

\subsection{Partial Conclusions}

For the same metal, the highest $k_{\mathrm{obs}}$ was achieved with smaller particles, i.e. nano ZVI comparing to micro ZVI, although the opposite was observed for $k_{\mathrm{SA}}$, which was attributed to differences between amorphous and crystalline structures. Between $\mathrm{Zn}$ and ZVI monometallic and bimetallic particles, a higher reactivity $\left(k_{\mathrm{obs}}\right.$ and $\left.k_{\mathrm{SA}}\right)$ was observed 
for those containing the metal that has the lowest reduction potential (Zn). Among all the metallic systems studied, the most effective degradation is associated with $\mathrm{Cu}$, which can be due to a different degradation mechanism. An even greater reactivity of this metal can be achieved when particles are submersed in the reaction medium for 24-h prior to treatment. Copper coating onto iron or zinc micro-sized particles revealed to enhance their reactivity due to the catalytic role of the secondary metal. In the absence of coating, the reactivity of these particles can also be enhanced by removing oxides from their surfaces with an acid washing pretreatment. All the metallic systems tested promoted CP dechlorination, although probably through different reduction mechanisms. Total chlorine removal was not achieved for any of the metals tested, since the majority of the identified products still contain chlorine in their structures, even after CP total degradation. Notwithstanding, other aspects besides pesticide removal has to be considered when evaluating these type of processes, once metals dissolution may raise an environmental concern. 
CONCLUSIONS 
Regarding Chapter I, the results enabled us to conclude that persulfate activated by UVA and/or iron species consists in an attractive process to degrade AMZcontaminated waters. However, toxicity assays revealed that processes which removed AMZ faster are not necessarily those promoting the highest toxicity removal. Nevertheless, the results shown in this chapter contribute to the AOPs state-of-the-art, since there are no other records in the literature dedicated to the study of AMZ degradation via persulfate-driven AOP nor via photolysis of $\mathrm{Fe}$ (III)-carboxylate complexes. As a future work related with this chapter we suggest that AMZ degradation products be identified and correlated with toxicity results shown in Section 5.

Regarding Chapter II, it is possible to conclude that chlorpyrifos dechlorination was effectively promoted by ZVM, especially by $\mathrm{Cu}^{0}$, resulting in less-chlorinated degradation products. The extremely high reactivity observed for copper against chlorpyrifos configures an important contribution of this work regarding the state-of-the art of zero-valent-metals for degradation of organochlorine pesticides, since $\mathrm{Cu}^{0}$ is a much less explored ZVM and very few literature reports its effectiveness on reductive dechlorination. Another aspect that requires further investigation is chlorpyrifos degradation at environmental concentrations, using lower copper dosages, in order to evaluate the effectiveness of this process under environmental conditions, without exceeding metal ions safety levels in waterbodies.

A process combining oxidative and reductive processes would be also interesting for future investigation. This can be accomplished by passing organochloridecontaminated water through a column filled with ZVM before degrading it via AOP. By doing so, firstly the organochlorine would be reduced, which would facilitate its following oxidation and, consequently, mineralization. 


\section{REFERENCES}

ABNT-NBR-12648. Aquatic ecotoxicology - chronic toxicity - method of test with gree algae (Chlorophyceae). Rio de Janeiro, 2011.

ABRAHAMSON, H.; REZVANI, A.; BRUSHMILLER, J. Photochemical and spectroscopic studies of complexes, of iron (III) with citric acid and other carboxylic acids. Inorganica Chimica Acta, v. 226, n. 1-2, p. 117-127, 1994.

AHMED, M. M.; CHIRON, S. Solar photo-Fenton like using persulphate for carbamazepine removal from domestic wastewater. Water Research, v. 48, n. 1, p. 229236, 2014.

AL-SHAMSI, M. A.; THOMSON, N. R. Treatment of organic compounds by activated persulfate using nanoscale zerovalent iron. Industrial and Engineering Chemistry Research, v. 52, n. 38, p. 13564-13571, 2013.

ANDERSEN, R. Algal Culturing Technique. San Diego: Academic Press, 2005.

ANDREOZZI, R. Advanced oxidation processes (AOP) for water purification and recovery. Catalysis Today, v. 53, n. 1, p. 51-59, 1999.

AQUASTAT - FAO's Information system on water and agriculture, 2014, retrieved July 2016, 2015.

ARRAES, A.; MAUR, F. Use of Atrazine and groundwater availability in Brazil: case study Tianguá. Water availability, use and management. Anais de congresso, 2008

AVETTA, P. et al. Activation of persulfate by irradiated magnetite: implications for the degradation of phenol under heterogeneous photo-fenton-like conditions. Environmental Science \& Technology, v. 49, n. 2, p. 1043-1050, 2015.

BABUPONNUSAMI, A.; MUTHUKUMAR, K. A review on Fenton and improvements to the Fenton process for wastewater treatment. Journal of Environmental Chemical Engineering, v. 2, n. 1, p. 557-572, 2014. 
BADER, H.; STURZENEGGER, V.; HOIGNÉ, J. Photometric method for the determination of low concentrations of hydrogen peroxide by the peroxidase catalyzed oxidation of N,N-diethyl-p-phenylenediamine (DPD). Water Research, v. 22, n. 9, p. 1109-1115, 1988.

BALMER, M. E.; SULZBERGER, B. Atrazine degradation in irradiated iron/oxalate Systems: effects of pH and oxalate. Environmental Science \& Technology, v. 33, n. 14, p. 2418-2424, 1999.

BEDUK, F.; AYDIN, M. E.; OZCAN, S. Degradation of malathion and parathion by ozonation, photolytic ozonation, and heterogeneous catalytic ozonation processes. Clean - Soil, Air, Water, v. 40, n. 2, p. 179-187, 2012.

BELAY, T. A. et al. Reduction of concentrated nitrate by using in situ synthesized zerovalent copper. Water Science and Technology, v. 72, n. 6, p. 960-965, 2015.

BENKELBERG, H. J.; WARNECK, P. Photodecomposition of Iron(Iii) Hydroxo and Sulfato Complexes in Aqueous-Solution - Wavelength Dependence of Oh and So4Quantum Yields. Journal of Physical Chemistry, v. 99, n. 14, p. 5214-5221, 1995.

BENNEDSEN, L. R.; MUFF, J.; SøGAARD, E. G. Influence of chloride and carbonates on the reactivity of activated persulfate. Chemosphere, v. 86, n. 11, p. 1092-1097, 2012.

BEZBARUAH, A. N.; THOMPSON, J. M.; CHISHOLM, B. J. Remediation of alachlor and atrazine contaminated water with zero-valent iron nanoparticles. Journal of environmental science and health. Part. B, Pesticides, food contaminants, and agricultural wastes, v. 44, n. 910699465, p. 518-524, 2009.

BLOCK PA, BROWN RA, ROBINSON D., Novel activation technologies for sodium persulfate in situ chemical oxidation. Proceeding, Fourth International Conference on Remediation of Chlorinated and recalcitrant compounds, Monterey, CA, USA, May 24-27, Paper 2A-05,2004.

BODRATO, M.; VIONE, D. APEX ( Aqueous Photochemistry of Environmentally occurring Xenobiotics ): a free software tool to predict the kinetics of photochemical processes. Environmental science: processes and impacts, v. 16, p. 732-740, 2014. 
BOOTHARAJU, M. S.; PRADEEP, T. Understanding the degradation pathway of the pesticide Chlorpyrifos by noble metal nanoparticles. Langmuir, 2012.

BRANSFIELD, S. J.; CWIERTNY, D. M.; ROBERTS, A. L. Influence of Copper Loading and Surface Coverage on the Reactivity of Granular Iron toward. Environmental Science \& Technology, v. 40, n. 5, p. 1485-90, 2006.

BRAUN, A. M.; OLIVEROS, E.; MAURETTE, M.-T. Photochemical technology. New York: Wiley \& Sons, 1991.

BRATERMAN, P. et al., Photo-oxidation of iron(II) in water between $\mathrm{pH} 7.5$ and 4.0. Journal of Chemical society, Dalton transactions, p. 1441-1445, 1984.

BRATSCH, S. Standard electrode potentials and temperature coefficients in water at 298.15K.pdf. Journal of physical chemistry, v. 18, p. 1, 1988.

BUCK, R. P.; SINGHADEJA, S.; ROGERS, L. B. Ultraviolet Absorption Spectra of Some Inorganic Ions in Aqueous Solutions. Analytical Chemistry, v. 26, n. 7, p. 12401242, jul. 1954.

BURNS, M.; RITCHIE, R. J.; KENNEDY, I. R. Probabilistic risk assessment of diuron and prometryn in the Gwydir River catchment, Australia, with the input of a novel bioassay based on algal growth. Ecotoxicology and Environmental Safety, v. 106, p. 213-219, 2014.

BUXTON, G. V et al. Critical review of rate constants for reactions of hydrated electrons, hydrogen atoms and hydroxyl radicals $\left(\mathrm{OH} / \mathrm{O}^{-}\right)$in aqueous Solution. Atomic Energy, v. 17, n. 1988, p. 513-886, 1988.

CAIANELO, M. et al. Antimicrobial activity against Gram-positive and Gram-negative bacteria during gatifloxacin degradation by hydroxyl radicals. Environmental Science and Pollution Research, v. 24, n.7,p. 6288-6298, 2017.

CAO, J. et al. Synthesis of monodispersed CMC-stabilized $\mathrm{Fe}-\mathrm{Cu}$ bimetal nanoparticles for in situ reductive dechlorination of 1,2,4-trichlorobenzene. Science of the Total Environment, v. 409, n. 11, p. 2336-2341, 2011. 
CAO, J. S. et al. Oxidation of lindane with $\mathrm{Fe}(\mathrm{II})$-activated sodium persulfate. Environmental Engineering Science, v. 25, n. 2, p. 221-228, 2008.

CARNEIRO, F. F. et al. Dossiê Abrasco 2015 - Um alerta sobre os impactos dos agrotóxicos na saúde. Rio de Janeiro/ São Paulo Expressão Popular, 2015.

CHOI, J. H.; KIM, Y. H. Reduction of 2,4,6-trichlorophenol with zero-valent zinc and catalyzed zinc. Journal of Hazardous Materials, v. 166, n. 2-3, p. 984-991, 2009.

CHU, W.; LAU, T. K.; FUNG, S. C. Effects of combined and sequential addition of dual oxidants $\left(\mathrm{H}_{2} \mathrm{O}_{2} / \mathrm{S}_{2} \mathrm{O}_{8}{ }^{2-}\right)$ on the aqueous carbofuran photodegradation. Journal of Agricultural and Food Chemistry, v. 54, n. 26, p. 10047-52, 2006.

CRIMI ML, TAYLOR J., Experimental evaluation of catalyzed hydrogen peroxide and sodium persulfate for destruction of BTEX contaminants., Soil Sediment Contamination, v. 16, p. 29-45, 2007.

CIEŚLA, P. et al. Homogeneous photocatalysis by transition metal complexes in the environment. Journal of Molecular Catalysis A: Chemical, v. 224, n. 1-2, p. 17-33, 2004.

CORREIA, A. V.; NOGUEIRA, R. F. P. 2,4-Dichlorophenoxyacetic acid (2,4-D) degradation promoted by nanoparticulate zerovalent iron (nZVI) in aerobic suspensions. Journal of Environmental Management, v. 121, p. 72-79, 2013.

DANTAS, R. F. et al. Sulfamethoxazole abatement by means of ozonation. Journal of Hazardous Materials, v. 150, n. 3, p. 790-794, 2008.

DENG, J. et al. Zero-valent iron/persulfate(Fe0/PS) oxidation acetaminophen in water. International Journal of Environmental Science and Technology, v. 11, n. 4, p. 881890, 2014.

DERBALAH, A.; ISMAIL, A.; SHAHEEN, S. Monitoring of organophosphorus pesticides and remediation technologies of the frequently detected compound (chlorpyrifos) in drinking water. Polish journal of chemical technology, v. 15, n. 3, p. 25-34, 2013. 
DONNER, E. et al. Ecotoxicity of carbamazepine and its UV photolysis transformation products. Science of the Total Environment, v. 443, p. 870-876, 2013.

DUAN, J. et al. A new approach to 4-chlorophenol dechlorination on monometallic copper compared to its $\mathrm{Cu} / \mathrm{Fe}$ bimetallic system. Chemical Engineering Journal, v. 304, p. 282-288, 2016.

EPA (US). Pesticide fact sheet: Amicarbazone. Washington, D.C.: GPO, 2005. Acessed May 18, 2015a.

EPA (US). Persistent organic pollutants - global issue response, Available in http://www2.epa.gov/international-cooperation/persistent-organic-pollutants-global-issueglobal-response, Acessed 25/07/2015, 2015 b.

EPA (US). Types of Pesticides. Available in http://www.epa.gov/pesticides/about/types.htm, Acessed July 16, 2015c.

EPA (US), Chlorpyrifos; Tolerance Revocation; Proposed Rule; 2015, Acessed April 4 2016.

FARRUGGIA, F. T. et al. Refined assessment for Atrazine. Draft ecological risk assessments for triazines. United States Enviromental Protection Agency, Washington D.C., 20460: [s.n.]. Disponível em: <https://www.epa.gov/ingredients-used-pesticideproducts/draft-ecological-risk-assessments-triazines>.

FAUST, B. C.; ZEPP, R. G. Photochemistry of aqueous iron(III)-polycarboxylate complexes: roles in the chemistry of atmospheri and surface waters. Environmental Science \& Technology, v. 27, n. 12, p. 2517-2522, 1993.

FENG, X.; DING, S.; XIE, F. Photochemical Degradation of Dimethyl Phthalate by $\mathrm{Fe}(\mathrm{III}) /$ tartrate/H 2 O 2 System. Bulletin of the Korean Chemical Society, v. 33, n. 11, p. 3686-3690, 20 nov. 2012.

FERREIRA, S. L. C. et al. Doehlert matrix: A chemometric tool for analytical chemistry - Review. Talanta, v. 63, n. 4, p. 1061-1067, 2004. 
FERREIRA, S. L. C. et al. Statistical designs and response surface techniques for the optimization of chromatographic systems. Journal of Chromatography A, v. 1158, n. 1-2, p. 2-14, 2007.

FORSBERG, B.; PENN, R. L. E. E.; KIM, C. S. Chemical Transformations during Aging of Zerovalent Iron Nanoparticles in the Presence of Common Groundwater Dissolved Constituents. p. 3455-3461, 2010.

FREITAS, A. M. et al. Ecotoxicity evaluation of a WWTP effluent treated by solar photo-Fenton at neutral $\mathrm{pH}$ in a raceway pond reactor. Environmental Science and Pollution Research, p. 1-12, 2016.

GAO, Y. Q. et al. Ultraviolet (UV) light-activated persulfate oxidation of sulfamethazine in water. Chemical Engineering Journal, v. 195-196, p. 248-253, 2012.

GERHARDT, A.; UD-DAULA, A.; SCHRAMM, K. W. Tetrahymena spp. (Protista, Ciliophora) as test species in rapid multilevel ecotoxicity tests. Acta Protozoologica, v. 49, n. 4, p. 271-280, 2010.

GHAUCH, A.; AYOUB, G.; NAIM, S. Degradation of sulfamethoxazole by persulfate assisted micrometric $\mathrm{Fe}^{0}$ in aqueous solution. Chemical Engineering Journal, v. 228, p. 1168-1181, 2013.

GLAZE, W. H.; KANG, J.-W.; CHAPIN, D. H. The chemistry of water treatment processes involving ozone, hydrogen peroxide and ultraviolet radiationOzone: Science \& Engineering, 1987.

GLEBOV, E. M. et al. Intermediates in photochemistry of Fe(III) complexes with carboxylic acids in aqueous solutions. Photochem. Photobiol. Sci., v. 10, n. 3, p. 425430, 2011.

GOLDSTEIN, S.; RABANI, J. The ferrioxalate and iodide - iodate actinometers in the UV region. Journal of Photochemistry and Photobiology A: Chemistry, v. 193, p. 50$55,2008$. 
GRAÇA, C. A. L.; VElosA, A. C. DE; TEIXEIRA, A. C. S. C. Amicarbazone degradation by UVA-activated persulfate in the presence of hydrogen peroxide or $\mathrm{Fe}^{2+}$. Catalysis Today, v. 280, p. 80-85, 2017.

GRIBBLE, G. W. Chlorine and Health. American Council on Science and Health, 1995.

GUAN, X. et al. The limitations of applying zero-valent iron technology in contaminants sequestration and the corresponding countermeasures: The development in zero-valent iron technology in the last two decades (1994-2014). Water Research, v. 75, p. 224$248,2015$.

HAN, D. et al. New insights into the role of organic chelating agents in Fe ( II ) activated persulfate processes. CHEMICAL ENGINEERING JOURNAL, v. 269, p. 425-433, 2015.

HAN, Y. et al. Reduction of $\mathrm{N}$-Nitrosodimethylamine with zero-valent zinc. Water Research, v. 47, n. 1, p. 216-224, 2012.

HANDORE, A. V; KHANDELWAL, S. R.; BHAVSAR, S. P. Antimicrobial activity of pesticide residue and implications of international MRLS in Indian and imported wines. International journal of development research, v. 5, n. 4, p. 3967-3974, 2015.

HOSSAIN, M. S. et al. Determination of selected pesticides in water samples adjacent to agricultural fields and removal of organophosphorus insecticide chlorpyrifos using soil bacterial isolates. Applied Water Science, v. 5, n. 2, p. 171-179, 2014.

HUANG, C. C.; LO, S. L.; LIEN, H. L. Zero-valent copper nanoparticles for effective dechlorination of dichloromethane using sodium borohydride as a reductant. Chemical Engineering Journal, v. 203, p. 95-100, 2012.

HWANG, Y.-H.; KIM, D.-G.; SHIN, H.-S. Mechanism study of nitrate reduction by nano zero valent iron. Journal of hazardous materials, v. 185, n. 2-3, p. 1513-1521, 2011.

IBGE, Anuários Estatísticos 2011, Volume 71, São Paulo.

IBGE, Atlas de Saneamento, 2012. 
JI, Y. et al. Heat-activated persulfate oxidation of atrazine: Implications for remediation of groundwater contaminated by herbicides. Chemical Engineering Journal, v. 263, p. 45-54, 2015.

JIN, L.; DAI, B. TiO2 activation using acid-treated vermiculite as a support: Characteristics and photoreactivity. Applied Surface Science, v. 258, n. 8, p. 3386-3392, 2012.

JOHNSON, T. L.; SCHERER, M. M.; TRATNYEK, P. G. Kinetics of halogenated organic compound degradation by iron metal. Environmental Science \& Technology, v. 30, n. 8, p. 2634-2640, 1996.

JOSEPH, J. M.; VARGHESE, R.; ARAVINDAKUMAR, C. T. Photoproduction of hydroxyl radicals from $\mathrm{Fe}(\mathrm{III})$-hydroxy complex: a quantitative assessment. Journal of Photochemistry and Photobiology A: Chemistry, v. 146, n. 1-2, p. 67-73, 10 dez. 2001 .

KIM, Y.-H.; CARRAWAY, E. R. Dechlorination of chlorinated phenols by zero valent zinc. Environmental Technology, v. 24, n. December, p. 1455-1463, 2003.

KIM, Y. H.; CARRAWAY, E. R. Dechlorination of pentachlorophenol by zero valent iron and modified zero valent irons. Environmental Science \& Technology, v. 34, n. 10, p. 2014-2017, 2000.

KOCAR, B. D.; INSKEEP, W. P. Photochemical Oxidation of As(III) in Ferrioxalate Solutions. Environmental Science \& Technology, v. 37, n. 8, p. 1581-1588, abr. 2003.

KOLÁ̌̌, M. et al. Degradation of organic pollutants in aquatic environment photoinduced by Fe(III)Cit complex: Impact of TiO2. Catalysis Today, v. 161, n. 1, p. 127-132, 2011.

KÖNIGSBERGER, L. C. et al. Complexation of iron(III) and iron(II) by citrate. Implications for iron speciation in blood plasma. Journal of Inorganic Biochemistry, v. 78, n. 3, p. 175-184, 2000. 
KORNWEITZ, H.; BURG, A.; MEYERSTEIN, D. Plausible mechanisms of the fentonlike reactions, $\mathrm{M}=\mathrm{Fe}(\mathrm{II})$ and $\mathrm{Co}(\mathrm{II})$, in the presence of $\mathrm{RCO}_{2}{ }^{-}$substrates: Are $\mathrm{OH}$ radicals formed in the process? Journal of Physical Chemistry A, v. 119, n. 18, p. 4200-4206, 2015.

KRALJ, M. B.; FRANKO, M.; TREBS, P. Photodegradation of organophosphorus insecticides - Investigations of products and their toxicity using gas chromatography mass spectrometry and AChE-thermal lens spectrometric bioassay. Chemosphere, v. 67, p. 99-107, 2007.

KRÄMER, W.; SCHIRMER, U. Modern Crop Protection Compounds: Herbicides. Madison: Wiley-VCH, 2012. v. 1

KWON, M. et al. Comparative evaluation of ibuprofen removal by $\mathrm{UV} / \mathrm{H}_{2} \mathrm{O}^{2}$ and $\mathrm{UV} / \mathrm{S}_{2} \mathrm{O}_{8}{ }^{2-}$ processes for wastewater treatment. Chemical Engineering Journal, v. 269, p. 379-390, 2015.

LAAT, J. DE; LE, G. T.; LEGUBE, B. A comparative study of the effects of chloride , sulfate and nitrate ions on the rates of decomposition of $\mathrm{H}_{2} \mathrm{O}_{2}$ and organic compounds by $\mathrm{Fe}(\mathrm{II}) / \mathrm{H}_{2} \mathrm{O}_{2}$ and $\mathrm{Fe}(\mathrm{III}) / \mathrm{H}_{2} \mathrm{O}_{2}$. Chemosphere, v. 55, p. 715-723, 2004.

LARI, S. Z. et al. Comparison of pesticide residues in surface water and ground water of agriculture intensive areas. Journal of environmental health science \& engineering, v. 12, n. 1, p. 11, 2014.

LAZAR, M. A.; VARGHESE, S.; NAIR, S. S. Photocatalytic water treatment by titanium dioxide: Recent Updates. Catalysts, v. 2, p. 572-601, 2012.

LEE, C.-L.; JOU, C.-J. G.; WANG, H. P. Enhanced degradation of chlorobenzene in aqueous solution using microwave-induced zero-valent iron and copper particles. Water Environment Research, v. 82, n. 7, p. 642-647, 2010.

LEE, C.; YOON, J. Determination of quantum yields for the photolysis of Fe(III)hydroxo complexes in aqueous solution using a novel kinetic method. Chemosphere, v. 57, n. 10, p. 1449-1458, 2004. 
LI, H. et al. Role of inorganic ions and dissolved natural organic matters on persulfate oxidation of acid orange 7 with zero-valent iron. RSC Advances, v. 5, p. 99935-99943, 2015.

LIANG, C. et al. A rapid spectrophotometric determination of persulfate anion in ISCO. Chemosphere, v. 73, n. 9, p. 1540-1543, 2008.

LIANG, C.; GUO, Y.-Y.; PAN, Y.-R. A study of the applicability of various activated persulfate processes for the treatment of 2,4-dichlorophenoxyacetic acid. International Journal of Environmental Science and Technology, v. 11, n. 2, p. 483-492, 2014.

LIANG, C.; LIANG, C.-P.; CHEN, C.-C. pH dependence of persulfate activation by EDTA/Fe(III) for degradation of trichloroethylene. Journal of contaminant hydrology, v. 106, n. 3-4, p. 173-82, 2009.

LIEN, H.-L.; ZHANG, W. Hydrodechlorination of Chlorinated Ethanes by Nanoscale $\mathrm{Pd} / \mathrm{Fe}$ Bimetallic Particles. Journal of Environmental Engineering, v. 131, n. 1, p. 4 $10,2005$.

LIN, Y.-T.; LIANG, C.; CHEN, J.-H. Feasibility study of ultraviolet activated persulfate oxidation of phenol. Chemosphere, v. 82, n. 8, p. 1168-1172, 2011.

LIU, C. S. et al. Oxidative degradation of propachlor by ferrous and copper ion activated persulfate. Science of the Total Environment, v. 416, p. 507-512, 2012.

LIU, Y.-S. et al. Photodegradation of three benzotriazoles induced by four FeIII?carboxylate complexes in water under ultraviolet irradiation. Environmental Chemistry, v. 10, n. 2, p. 135, 2013.

LOURES, C. C. A et al. Advanced Oxidative Degradation Processes : Fundamentals and Applications. International Review of Chemical Engineering, v. 5, n. March, p. 102$120,2013$.

LUTZE, H. Sulfate radical radical oxidation in water treatment. PhD. Dissertation . Institut für Instrumentelle Analytische Chemie of Universität Duisburg-Essen, 2013. 
LUTZE, H. V. et al. Degradation of chlorotriazine pesticides by sulfate radicals and the influence of organic matter. Environmental Science \& Technology, v. 49, n. 3, p. 1673$1680,2015$.

GLEBOV, M. E. et al. Intermediates in photochemistry of Fe(III) complexes with carboxylic acids in aqueous solutions. Photochemical and Photobiological Sciences, v. 10, n. 3, p. 425-430, 2011.

MA, Y.-S.; SUNG, C.-F. Investigation of carbofuran decomposition by a combination of ultrasound and Fenton process. Journal of Environmental Engineering and Management, v. 20, n. 4, p. 213-219, 2010.

MACKUL'AK, T.; PROUSEK, J.; ŠVORC, L. Degradation of atrazine by Fenton and modified Fenton reactions. Monatshefte fur Chemie, v. 142, n. 6, p. 561-567, 2011.

MANAHAN E., S. Fundamentals of environmental and toxicological chemistry: sustainable science. CRC Press 2013, 2013.

MANENTI, D. R. et al. Insights into solar photo-Fenton process using iron(III)-organic ligand complexes applied to real textile wastewater treatment. Chemical Engineering Journal, v. 266, n. April 2015, p. 203-212, 2015.

MARINO, D.; RONCO, A. Cypermethrin and Chlorpyrifos concentration levels in surface water bodies of the Pampa Ondulada, Argentina. Bulletim of Environmental Contaminants Toxicology, v. 75, p. 820-826, 2005.

MARK, G. et al. The photolysis of potassium peroxodisulphate in aqueous solution in the presence of tert-butanol: a simple actinometer for $254 \mathrm{~nm}$ radiation. Journal of Photochemistry and Photobiology A: Chemistry, v. 55, n. 2, p. 157-168, 1990.

MAVROPOULOS, ELENA., A hidroxiapatita como absorvedor de metais. Dissertação de Mestrado, Fundação Oswaldo Cruz, Escola Nacional de Saúde Pública; 1999.

MATHESON, L. J.; TRATNYEK, P. G. Reductive Dehalogenation of Chlorinated Methanes by Iron Metal. Environmental Science \& Technology, v. 28, n. 12, p. 20452053, 1994. 
MEHDINIA, A.; SHEGEFTI, S.; SHEMIRANI, F. Removal of lead(II), copper(II) and zinc(II) ions from aqueous solutions using magnetic amine-functionalized mesoporous silica nanocomposites. Journal of the Brazilian Chemical Society, v. 26, n. 11, p. 2249-2257, 2015.

MENG, J. et al. Heterogeneous ozonation of suspended malathion and chlorpyrifos particles. Chemosphere, v. 79, n. 4, p. 394-400, 2010.

MILLER, C. J.; ROSE, A. L.; WAITE, T. D. Importance of Iron complexation for fentonmediated hydroxyl radical production at circumneutral pH. Frontiers in Marine Science, v. 3, n. August, p. 1-13, 2016.

MIRANDA-GARCIA, N. et al. Degradation study of 15 emerging contaminants at low concentration by immobilized $\mathrm{TiO} 2$ in a pilot plant. Catalysis Today, v. 151, n. 1-2, p. 107-113, 2010.

MORALES, J.; HUTCHESON, R.; CHENG, I. F. Dechlorination of chlorinated phenols by catalyzed and uncatalyzed Fe (0) and Mg (0) particles. v. 90, p. 97-108, 2002.

MOREIRA, F. C. et al. Degradation of trimethoprim antibiotic by UVA photoelectroFenton process mediated by Fe ( III )- carboxylate complexes. Applied Catalysis B: Environmental, v. 162, p. 34-44, 2015.

MORTATTI, F. J. et al. Determination of iron in natural waters and plant material with 1,10-phenanthroline by flow injection analysis. Analyst, v. 107, 659-6, p. 659-663, 1982.

MORTLAND;, M. M.; RAMAN, K. V. Catalytic hydrolysis of some organic phosphate pesticides by copper (II). Journal of agricultural and food chemistry, v. 15, n. 11, p. 163-167, 1967.

MUHAMAD, S. G. Kinetic studies of catalytic photodegradation of chlorpyrifos insecticide in various natural waters. Arabian Journal of Chemistry, v. 3, n. 2, p. 127133, 2010.

MUNTER, R. Advanced Oxidation Processes - Current Status and Prospect. Proceedings. Estonian Academy Science and Chemistry, v. 50, n. 2, p. 59-80, 2001. 
NAIR, A. S.; PRADEEP, T. Extraction of chlorpyrifos and malathion from water by metal nanoparticles. Journal of nanoscience and nanotechnology, v. 7, p. 1-7, 2007.

NETA, P.; HUIE, R. E.; ROSS, A. B. Rate constants for reaction of inorganic radicals in aqueous solution, 1988.

NOGUEIRA, R.; OLIVEIRA, M.; PATERLINI, W. Simple and fast spectrophotometric determination of $\mathrm{H} 2 \mathrm{O} 2$ in photo-Fenton reactions using metavanadate. Talanta, v. 66, n. 1, p. 86-91, 2005.

NTHUMBI, R. M. et al. Dechlorination of Selected Pesticides in Water using Catalytic Bimetallic (Fe-Pd) Nanoparticles Immobilized on MgAlO Support. In: Crystallizing Ideas - The Role of Chemistry. Cham: Springer International Publishing, 2016. p. 297322.

$\mathrm{OH}$, S. Y. et al. Oxidation of polyvinyl alcohol by persulfate activated with heat, $\mathrm{Fe} 2+$, and zero-valent iron. Journal of Hazardous Materials, v. 168, n. 1, p. 346-351, 2009.

OLlER, I.; MALATO, S.; SÁNCHEZ-PÉREZ, J. A. Combination of Advanced Oxidation Processes and biological treatments for wastewater decontamination-A review. Science of the Total Environment, v. 409, n. 20, p. 4141-4166, 2011.

OLMEZ-HANCI, T.; ARSLAN-ALATON, I.; GENC, B. Degradation of the nonionic surfactant TritonTM X-45 with HO and SO4- - Based advanced oxidation processes. Chemical Engineering Journal, v. 239, p. 332-340, 2014.

OPPENLÄNDER, T. Photochemical Purification of Water and Air. Germany: Wiley VCH, 2003.

OU, X. et al. Photocatalytic reaction by Fe(III)-citrate complex and its effect on the photodegradation of atrazine in aqueous solution. Journal of Photochemistry and Photobiology A: Chemistry, v. 197, n. 2-3, p. 382-388, 2008.

PARK, J. S. et al. A kinetic and ESR investigation of iron(II) oxalate oxidation by hydrogen peroxide and dioxygen as a source of hydroxyl radicals. Free radical research, v. 27, n. 5, p. 447-458, 1997. 
PEIXOTO, A. L.; TEIXEIRA, A. C. S. C. Degradation of amicarbazone herbicide by photochemical processes. Journal of Photochemistry and Photobiology A: Chemistry, v. 275, p. 54-64, 2014.

PEREIRA, W. S.; FREIRE, R. S. Ferro zero: uma nova abordagem para o tratamento de águas contaminadas com compostos orgânicos poluentes. Química Nova, v. 28, n. 1, p. 130-136, fev. 2005.

PEREIRA, W. S.; FREIRE, R. S. Azo dye degradation by recycled waste zero-valent iron powder. Journal of the Brazilian Chemical Society, v. 17, n. 5, p. 832-838, 2006.

PERSOONE, G.; JANSSEN, C.; COEN, W. DE. New microbiotests for routine toxicity screening and biomonitoring. Springer, 2000.

PETRI, G. B. et al. In situ chemical oxidation for groundwater remediation. Springer, New York, 2011.

PHENRAT, T.; SALEH, N. Aggregation and Sedimentation of Aqueous Nanoscale Zerovalent Iron Dispersions. Environtal Science \& Technology, v. 41, n. 1, p. 284-290, 2007.

PIGNATELLO, J. J.; OLIVEROS, E.; MACKAY, A. Advanced Oxidation Processes for Organic Contaminant Destruction Based on the Fenton Reaction and Related Chemistry. Critical Reviews in Environmental Science and Technology, v. 36, n. 1, p. 1-84, 2006.

PONDER, S. M.; DARAB, J. G.; MALLOUK, T. E. Remediation of Cr(VI) and Pb(II) aqueous solutions using supported, nanoscale zero-valent iron. Environmental Science \& Technology, v. 34, n. 12, p. 2564-2569, 2000.

POZDNYAKOV, I. et al. Degradation of herbicide 2,4-dichlorophenoxybutanoic acid in the photolysis of $[\mathrm{FeOH}]^{2+}$ and $\left[\mathrm{Fe}(\mathrm{Ox})_{3}\right]^{3-}$ complexes: A mechanistic study. Chemosphere, v. 146, p. 280-288, 2016.

POZDNYAKOV, I. P. et al. Photophysics of $\mathrm{Fe}(\mathrm{III})$-tartrate and $\mathrm{Fe}(\mathrm{III})-$ citrate complexes in aqueous solutions. Chemical Physics Letters, v. 530, p. 45-48, 2012.

PROTOXKIT. Fresh Water Toxicity Test with a Ciliate Protozoan. MicroBioTests Inc., 1998. 
RACKE, K. D.; LASKOWSKI, D. A.; SCHULTZ, M. R. Resistance of Chlorpyrifos to Enhanced Biodegradation in Soil. Journal agriculture food chemistry, v. 38, n. 6, p. 1430-36, 1990.

RADIX, P. et al. Comparison of four chronic toxicity tests using algae, bacteria, and invertebrates assessed with sixteen chemicals. Ecotoxicology and environmental safety, v. 47, n. 2, p. 186-94, 2000.

RAHARINIRINA， D., RAMANANTSIZEHENA,G., LAHATRA, F., RAZAFINDRAMISA, N.. Comparison of $\mathrm{UV} / \mathrm{H}_{2} \mathrm{O}_{2}$ and $\mathrm{UV} / \mathrm{S}_{2} \mathrm{O}_{8}{ }^{2-}$ processes for the decoloration of azo dyes congo red in various kinds of water. Fourth High-Energy Physics International Conference, Madagascar: 2009

RAO, Y. F. et al. Degradation of carbamazepine by Fe(II)-activated persulfate process. Journal of Hazardous Materials, v. 268, p. 23-32, 2014.

RATHORE, H., NOLLET, L. Pesticides: evaluation of environmental pollution. CRC Press, 2012.

REDDY, A. V. B. et al. Remediation of Chlorpyrifos-Contaminated Soils by LaboratorySynthesized Zero-Valent Nano Iron Particles: Effect of $\mathrm{pH}$ and Aluminium Salts. Journal of Chemistry, v. 2013, p. 1-7, 2013.

REDDY, A. V. et al. Relative efficiency comparison of carboxymetil cellulose (CMC) stabilized $\mathrm{Fe}^{0}$ and $\mathrm{Fe}^{0} / \mathrm{Ag}$ nanoparticles for rapid degradation of chlorpyrifos in aqueous solutions. Digest Journal of Nanomaterials \& Biostructures, v. 10, p. 331-340, 2015.

RIZZO, L. Bioassays as a tool for evaluating advanced oxidation processes in water and wastewater treatment. Water Research, v. 45, n. 15, p. 4311-4340, 2011.

ROBERT W. GILLHAM, KAYLENE RITTER, Y. Z. \& M. S. O. Factors in the LongTerm Performance of Granular Iron PRBs. Ground water, v. 32, p. 352-67, 1994.

SAGGIORO, E. M. et al. Photo-decolorization and ecotoxicological effects of solar compound parabolic collector pilot plant and artificial light photocatalysis of indigo carmine dye. Dyes and Pigments, v. 113, p. 571-580, 2015. 
SAHOO, M. K.; MARBANIANG, M.; SHARAN, R. N. UV light-assisted mineralisation and biodetoxification of Ponceau S with hydroxyl and sulfate radicals. Chemical Papers, v. 70, n. $8,2016$.

SAIEN, J.; SOLEYMANI, A. R.; SUN, J. H. Parametric optimization of individual and hybridized AOPs of $\mathrm{Fe} 2+/ \mathrm{H} 2 \mathrm{O} 2$ and UV/S2O82- for rapid dye destruction in aqueous media. Desalination, v. 279, n. 1-3, p. 298-305, 2011.

SAMET, Y., HMANI, E., ABDELHÉDI, R., Fenton and solar photo-Fenton processes for the removal of chlorpyrifos insecticide in wastewater, African Journals Online, v. 38, 2012.

SANTOS, E. A.; CORREIA, N. M. Herbicide detection in groundwater in Córrego RicoSP. Planta Daninha, v. 33, p. 147-155, 2015.

SARATHY, V. et al. Degradation of 1,2,3-Trichloropropane (TCP): Hydrolysis, elimination, and reduction by iron and zinc. Environmental Science \& Technology, v. 44, n. 2, p. 787-793, 2010.

SASS, J. B.; COLANGELO, A. European Union bans atrazine, while the United States negotiates continued use. International Journal of Occupational and Environmental Health, v. 12, n. 3, p. 260-267, 2006.

SATAPANAJARU, T.; ANURAKPONGSATORN, P. Remediation of Atrazinecontaminated soil and water by nano zerovalent iron. Water Air Soil Pollution, v. 192, p. 349-359, 2008.

SENA, A. R. et al. Application of Doehlert experimental design in the optimization of experimental variables for the Pseudozyma sp . (CCMB 306 ) and Pseudozyma sp .) CCMB 300 ) cell lysis. Ciência e Tecnologia de Alimentos, v. 32, n. 4, p. 762-767, 2012.

SERAGHNI, N. et al. Fe(III)-Citrate-Complex-Induced Photooxidation of 3Methylphenol in Aqueous Solution. International Journal of Photoenergy, v. 2012, n. Iii, p. 1-10, 2012. 
SHANTHAKUMAR, G. M. S. Silver nanoparticles: synthesis and application in mineralization of pesticides using membrane support. 2014.

SHI, L.; ZHANG, X.; CHEN, Z. Removal of Chromium (VI) from wastewater using bentonite-supported nanoscale zero-valent iron. Water Research, v. 45, n. 2, p. 886-892, 2010.

SHIH, Y. J. et al. Optimization of hexavalent chromium (Cr(VI)) reduction by granulated nano zero-valent iron (nZVI). In: Environmental Engineering and Computer Application: Proceedings of the 2014 International Conference on Environmental Engineering and Computer Application (ICEECA 2014). Hong Kong: p. 139-143.

SHRIVASTAVA, A.; GUPTA, V.; ARTICLE, R. Methods for the determination of limit of detection and limit of quantitation of the analytical methods. Chronicles of Young Scientists, v. 2, n. 1, p. 21-25, 2011.

SHUKLA, P. R. et al. Photocatalytic oxidation of phenolic compounds using zinc oxide and sulphate radicals under artificial solar light. Separation and Purification Technology, v. 70, n. 3, p. 338-344, 2010.

SILVA, M. P. et al. Photochemical fate of amicarbazone in aqueous media: laboratory measurement and simulations. Environmental Engineering Science, v. 32, n. 8, p. 1-11, 2015.

SILVA, M. R. A. et al. Photo-Fenton degradation of the herbicide tebuthiuron under solar irradiation: Iron complexation and initial intermediates. Water Research, v. 44, n. 12, p. 3745-3753, 2010.

SINHA, S. N. et al. Effect of dissociation energy on ion formation and sensitivity of an analytical method for determination of chlorpyrifos in human blood, using gas chromatography - mass spectrometer (GC - MS in MS/MS). International journal of mass spectrometry, v. 253, p. 48-57, 2006.

SOHRABI, M. R. et al. Removal of Carmoisine edible dye by Fenton and photo Fenton processes using Taguchi orthogonal array design. Arabian Journal of Chemistry, 2014. 
SOUISSI, Y. et al. Identification and ecotoxicity of degradation products of chloroacetamide herbicides from UV-treatment of water. Science of the Total Environment, v. 458-460, p. 527-534, 2013.

SUN, Y.; PIGNATELlO, J. J. Photochemical reactions involved in the total mineralization of 2,4-D by $\mathrm{Fe}^{3+} / \mathrm{H}_{2} \mathrm{O}_{2} / \mathrm{UV}$. Environmental science \& technology, v. 27 , n. 2, p. 304-310, 1993.

TAN, C. et al. Degradation of antipyrine by $\mathrm{UV}, \mathrm{UV} / \mathrm{H}_{2} \mathrm{O}_{2}$ and UV/PS. Journal of Hazardous Materials, v. 260, p. 1008-1016, 2013.

TATUM, M., HARRIS, B. What is water remediation. available in http://www.wisegeek.com/what-is-water-remediation.htm, Accessed in July 26, 2015

TOTHILL, I. E.; TURNER, A. P. F. Developments in bioassay methods for toxicity testing in water treatment. TrAC - Trends in Analytical Chemistry, v. 15, n. 5, p. 178188, 1996.

TRATNYEK, P. G. et al. Permeable reactive barriers of iron and other zero-valent metals. Chemical Degradation Methods for Wastes and Pollutants: Environmental and Industrial Applications. p. 371-421. CRc Press. 2003.

TRATNYEK, P. G. et al. Environmental Applications of Zerovalent Metals : Iron vs . Zinc. In: Nanoscale Materials in Chemistry: Environmental Applications. ACS Symposium Series; American Chemical Society: Washington, DC, 2010. p. 165-178.

TROVÓ, A. G. et al. Degradation of sulfamethoxazole in water by solar photo-Fenton. Chemical and toxicological evaluation. Water Research, v. 43, n. 16, p. 3922-3931, 2009.

TROVÓ, A. G. et al. Degradation of the antibiotic amoxicillin by photo-Fenton process Chemical and toxicological assessment. Water Research, v. 45, n. 3, p. 1394-1402, 2011.

URBANO, V. R.; MANIERO, M. G.; DESIGN, U. Influence of pH and ozone dose on sulfaquinoxaline ozonation. Journal of Environmental Management, in press, 2016. 
$\begin{array}{llll}\text { UWEX. } & \text { Persistent } & \text { Pesticides. }\end{array}$ http://connectingthecoast.uwex.edu/Investigate/cpPersistantPesticides.html, Accessed in July 24, 2015.

VELOSA, A. C.; NASCIMENTO, C. A. O. Evaluation of sulfathiazole degradation by persulfate in Milli-Q water and in effluent of a sewage treatment plant. Environmental Science and Pollution Research, v. 24, n. 7, p. 6270-6277, 2017.

VOGNA, D. et al. Kinetic and chemical assessment of the $\mathrm{UV} / \mathrm{H}_{2} \mathrm{O}_{2}$ treatment of antiepileptic drug carbamazepine. Chemosphere, v. 54, n. 4, p. 497-505, 2004.

WANG, C.; ZHANG, W. Synthesizing nanoscale iron particles for rapid and complete dechlorination of TCE and PCBs. Environmental Science \& Technology, v. 31, n. 7, p. 2154-2156, 1997.

WANG, L. et al. Photoproduction and determination of hydroxyl radicals in aqueous solutions of $\mathrm{Fe}$ (III)-tartrate complexes: a quantitative assessment. Journal of Coordination Chemistry, v. 59, n. 7, p. 803-813, 2006.

WANG, X. H. et al. Comparison of toxicities to Vibrio fischeri and Fish based on discrimination of excess toxicity from baseline level. Plos One, v. 11, n. 2, p. 15-28, 2016.

WANG, Z. et al. Rapid transformation of 1,2,3,4-TCDD by $\mathrm{Pd} / \mathrm{Fe}$ catalysts. Chemosphere, v. 78, n. 2, p. 147-151, jan. 2010.

WEI, X. et al. Zero-valent iron (ZVI) activation of persulfate (PS) for oxidation of bentazon in water. Chemical Engineering Journal, v. 285, p. 660-670, 2016.

WELCH, K. D.; DAVIS, T. Z.; AUST, S. D. Iron autoxidation and free radical generation: effects of buffers, ligands, and chelators. Archives of biochemistry and biophysics, v. 397, n. 2, p. 360-369, 2002.

WENG, C.; TAO, H. Highly efficient persulfate oxidation process activated with $\mathrm{Fe}^{0}$ aggregate for decolorization of reactive azo dye Remazol Golden Yellow. Arabian Journal of Chemistry, 2015. 
WHO. Guidelines for Drinking-water Quality. available in: <http://www.ncbi.nlm.nih.gov/pubmed/15806952>.

WU, C.; LINDEN, K. G. Phototransformation of selected organophosphorus pesticides : Roles of hydroxyl and carbonate radicals. Water Research, v. 44, n. 12, p. 3585-94, 2010 .

WU, J.; LAIRD, D. A. Abiotic transformation of chlorpyrifos to chlorpyrifos oxon in chlorinated water. Environmental toxicology and chemistry / SETAC, v. 22, n. 2, p. 261-264, 2003.

XIANGHUA;, F.; JUAN;, M.; SHIMIN, D. Photolysis characteristics of Fe(III)-tartrate complex system. Chinese Journal of Environmental Engineering, v. 7, n. 7, p. 2557$2562,2013$.

$\mathrm{XU}, \mathrm{X}$. R. et al. Degradation of melatonin by UV, UV/ $/ \mathrm{H}_{2} \mathrm{O}_{2}, \mathrm{Fe} 2+/ \mathrm{H}_{2} \mathrm{O}_{2}$ and $\mathrm{UV} / \mathrm{Fe}^{2+} / \mathrm{H}_{2} \mathrm{O}_{2}$ processes. Separation and Purification Technology, v. 68 , n. 2, p. 261266, 2009.

YANG, S. et al. Degradation efficiencies of azo dye Acid Orange 7 by the interaction of heat, UV and anions with common oxidants: Persulfate, peroxymonosulfate and hydrogen peroxide. Journal of Hazardous Materials, v. 179, n. 1-3, p. 552-558, 2010.

ZAKOWSKI, K.; NAROZNY, M.; SZOCINSKI, M. Influence of water salinity on corrosion risk - the case of the southern Baltic Sea coast. Environmental Monitoring and Assessment, v. 186, p. 4871-4879, 2014.

ZAMORA P. P.; SOUZA C. L. Degradation of Azo - Dyes By Metallic Iron. Engenharia Sanitária e Ambiental, v. 11, n. 1, p. 16-20, 2006.

ZHANG, C. et al. Quantitation of hydroxyl radicals from photolysis of Fe(III)-citrate complexes in aerobic water. Environmental science and pollution research international, v. 13, p. 156-160, 2006.

ZHANG, Q. et al. Degradation of carbamazepine and toxicity evaluation using the UV/persulfate process in aqueous solution. Journal of Chemical Technology and Biotechnology, v. 90, p. 701-708, 2014. 
ZHANG, W.; WANG, C.; LIEN, H. Treatment of chlorinated organic contaminants with nanoscale bimetallic particles. Catalysis Today, v. 40, p. 387-95, 1998.

ZHAO, Z. et al. Rapid decolorization of water soluble azo-dyes by nanosized zero-valent iron immobilized on the exchange resin. Science in China, Series B: Chemistry, v. 51, n. 2, p. 186-192, 2008.

ZHOU, D.; WU, F.; DENG, N. Fe(III)-oxalate complexes induced photooxidation of diethylstilbestrol in water. Chemosphere, v. 57, n. 4, p. 283-291, 2004.

ZIN, M. T. . et al. Synthesis of Bimetallic Fe/Cu Nanoparticles with Different Copper Loading Ratios. International Journal of Chemical, Nuclear, Metallurgical and Materials Engineering, v. 7, n. 12, p. 669-673, 2013.

ZUO, Y.; HOIGNE, J. Photochemical decomposition of oxalic glyoxylic and pyruvic acid catalysed by iron in atmsopheric waters. Environmental Science \& Technology, v. 28, n. 7, p. 1231-1239, 1994.

ZUO, Y.; JÜRG, H. Formation of hydrogen peroxide and depletion of oxalic acid in atmospheric water by photolysis of iron(III)-oxalato complexes. Environ. Sci. Technol., v. 26, n. 5, p. 1014-1022, 1992. 


\section{APPENDIX A}

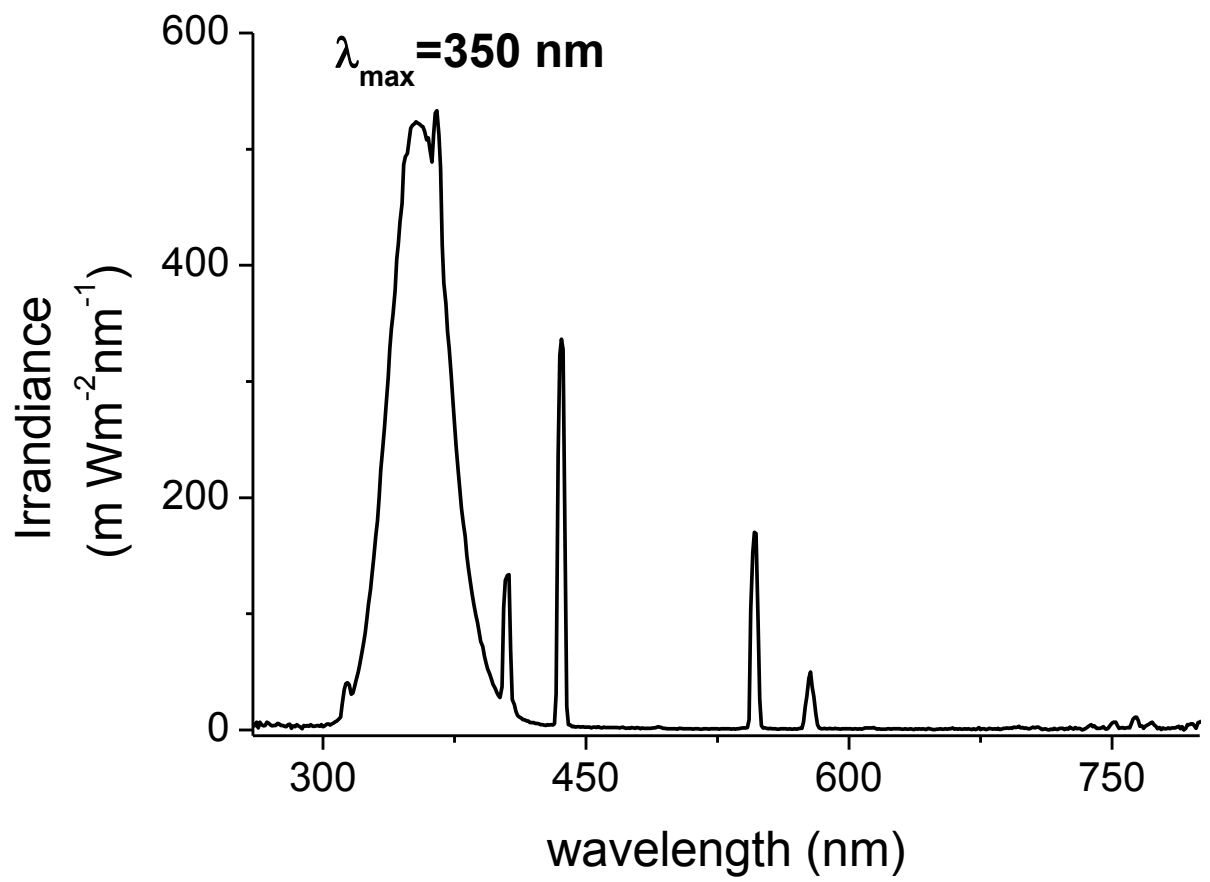

Figure A1. UVA lamp spectrum measured with a spectroradiometer.

$$
\int_{\lambda i}^{\lambda f} P(\lambda) d \lambda=\int_{315}^{400} P(\lambda) d \lambda=23281.08 \mathrm{mWm}^{-2}=23.3 \mathrm{Wm}^{-2}
$$

The photon flux and irradiance were also calculated via ferrioxalate actinometry, according to the methodology described in Oliveros et al. 1991:

The actinometer was prepared in the dark and consisted in a mixture of $0.75 \mathrm{~mol}$ $\mathrm{L}^{-1}$ oxalic acid $\left(\mathrm{H}_{2} \mathrm{C}_{2} \mathrm{O}_{4} .2 \mathrm{H}_{2} \mathrm{O}\right)$ and $0.15 \mathrm{~mol} \mathrm{~L}^{-1}$ ferric sulfate $\left(\mathrm{Fe}_{2}\left(\mathrm{SO}_{4}\right)_{3} .5 \mathrm{H}_{2} \mathrm{O}\right)$. After that, a $100-\mathrm{mL}$ volume of the actinometer solution was transferred to our photochemical reactor (Figure 4) in order to perform the experiment in the same conditions as other photochemical reactions present in our studies. After starting the irradiation, aliquots of $0.25 \mathrm{~mL}$ were collected every 2 minutes and mixed, in the dark, with $24.75 \mathrm{~mL}$ of a complexing mixture containing $0.5 \mathrm{~mol} \mathrm{~L}^{-1}$ of acetic acid, $0.5 \mathrm{~mol} \mathrm{~L}^{-1}$ of sodium acetate and $0.01 \mathrm{~mol} \mathrm{~L}^{-1}$ of 1,10-phenantroline. After that, the mixture was vigorously shaken and left for at least $30 \mathrm{~min}$, in order to let the complex of ferrous iron and 1,10-phenanthroline fully develop. The complex absorbance at $510 \mathrm{~nm}$ was determined using a UV-visible spectrophotometer and converted to Fe(II) concentration using the standard curve (Table A1). Standard solutions were prepared by the following procedure: $0,1.25,2.5,3.75,5$, 
$6.25 \mathrm{~mL} 0.4 \mathrm{mmol} \mathrm{L}^{-1} \mathrm{FeSO}_{4}$ were added to a series of $25 \mathrm{~mL}$ volumetric flasks and mixed with $6.25 \mathrm{~mL}$ of the complexing mixture. After 30 minutes, their absorbance was measured at $510 \mathrm{~nm}$.

Table A1. Absorbance of Fe standard Fe(II) solutions for ferrioxalate actinometry.

\begin{tabular}{c|cc}
\hline Sample Name & $\begin{array}{c}\text { Concentration } \\
\left(\mathbf{m o l ~ L}^{-1}\right)\end{array}$ & Absorbance \\
\hline BLANK & 0 & 0 \\
STD1 & $2.00 \times 10^{-5}$ & 0.2986 \\
STD2 & $4.00 \times 10^{-5}$ & 0.6859 \\
STD3 & $6.00 \times 10^{-5}$ & 0.8288 \\
STD4 & $8.00 \times 10^{-5}$ & 1.2873 \\
STD5 & $1.00 \times 10^{-4}$ & 1.3362 \\
\hline
\end{tabular}

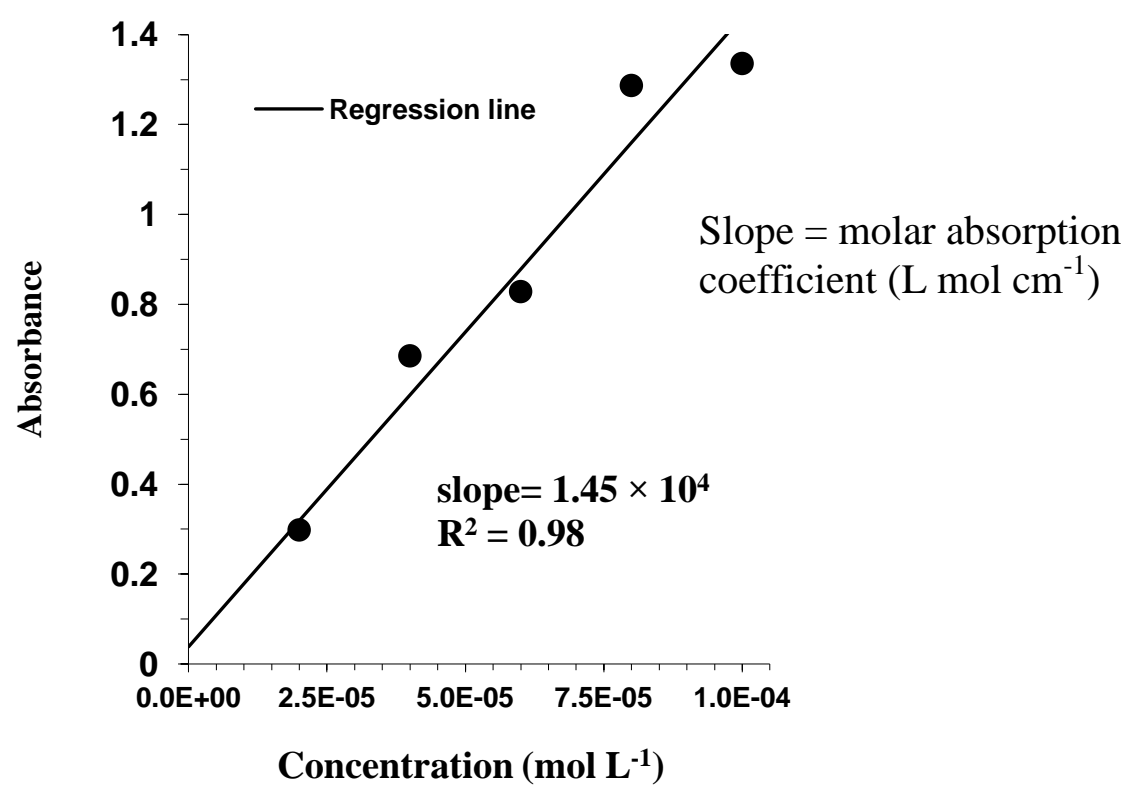

Figure A2. Standard curve for ferrioxalate actinometry. 
Table A2. Results of chemical actinometry.

\begin{tabular}{c|cccc}
\hline Irradiation Time & Absorbance & $\begin{array}{c}\text { Measured } \\
\text { concentration } \\
\left(\mathbf{m o l ~ L}^{-1}\right)\end{array}$ & $\begin{array}{c}\text { Concentration } \\
\text { of irradiated } \\
\text { sample } \\
\text { (mol L }\end{array}$ & $\begin{array}{c}\left.\mathbf{F e}^{\mathbf{2}}\right) \\
\text { photo- }^{2+} \\
\text { produced } \\
(\mathbf{m o l e s})\end{array}$ \\
\hline $\mathbf{0}$ & 0.0014 & 0 & 0 & 0 \\
$\mathbf{2}$ & 0.1679 & $9.25 \times 10^{-6}$ & $9.25 \times 10^{-4}$ & $9.25 \times 10^{-5}$ \\
$\mathbf{4}$ & 0.377 & $2.42 \times 10^{-5}$ & $2.42 \times 10^{-3}$ & $2.42 \times 10^{-4}$ \\
$\mathbf{6}$ & 0.5718 & $3.81 \times 10^{-5}$ & $3.81 \times 10^{-3}$ & $3.81 \times 10^{-4}$ \\
$\mathbf{8}$ & 0.7071 & $4.77 \times 10^{-5}$ & $4.77 \times 10^{-3}$ & $4.77 \times 10^{-4}$ \\
$\mathbf{1 0}$ & 0.8788 & $6.00 \times 10^{-5}$ & $6.00 \times 10^{-3}$ & $6.00 \times 10^{-4}$ \\
$\mathbf{1 2}$ & 1.1164 & $7.69 \times 10^{-5}$ & $7.69 \times 10^{-3}$ & $7.69 \times 10^{-4}$ \\
$\mathbf{1 4}$ & 1.2608 & $8.72 \times 10^{-5}$ & $8.72 \times 10^{-3}$ & $8.72 \times 10^{-4}$ \\
$\mathbf{1 6}$ & 1.4812 & $1.03 \times 10^{-4}$ & $1.03 \times 10^{-2}$ & $1.03 \times 10^{-3}$ \\
\hline
\end{tabular}

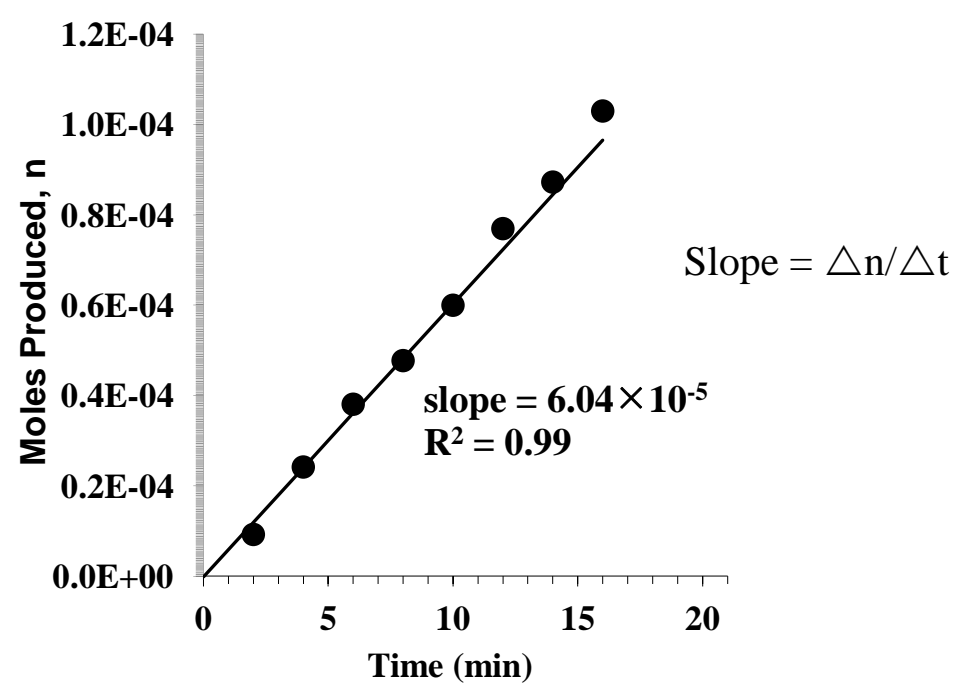

Figure A3. Photo generated Fe(II).

\section{Calculations}

The light intensity can be calculated by the following equations:

$\mathrm{I}=\Delta \mathrm{n} /\left(10^{-3} \times \Phi \times \mathrm{V}_{1} \times \mathrm{t}\right) \quad$ unit: Einstein $\mathrm{L}^{-1} \mathrm{~s}^{-1}$

where $\Delta \mathrm{n}=$ ferrous iron photo-generated (mole);

$\Phi=$ quantum yield. 1.22 was used, as the majority of UV light centered at 350

$\mathrm{nm}$ for the lamps used. This information was taken from Hatchard and Parker (1956).

$\mathrm{V}_{1}=$ irradiated volume $(100 \mathrm{~mL})$;

$\mathrm{t}=$ irradiation time $(\mathrm{s})$; 
$\Delta \mathrm{n}$ can be calculated by the equation below:

$\Delta \mathrm{n}=\left(10^{-3} \times \mathrm{V}_{1} \times \mathrm{V}_{3} \times \mathrm{C}_{\mathrm{t}}\right) / \mathrm{V}_{2}$

where $\mathrm{V}_{1}=$ irradiated volume $(100 \mathrm{~mL})$.

$\mathrm{V}_{2}=$ volume taken from the irradiated samples $(0.25 \mathrm{~mL})$.

$\mathrm{V}_{3}=$ volume after dilution for concentration determination $(25 \mathrm{~mL})$.

$\mathrm{C}_{\mathrm{t}}=$ concentration of ferrous iron after dilution $\left(\mathrm{mol} \mathrm{L}^{-1}\right)$.

$\mathrm{C}_{\mathrm{t}}$ can be calculated from the absorbance at $510 \mathrm{~nm}$ as follows.

$\mathrm{C}_{\mathrm{t}}=\mathrm{abs} /(\varepsilon .1)$

where $\mathrm{abs}=$ absorbance at $510 \mathrm{~nm}$.

$\varepsilon=$ molar absorption coefficient $\left(\mathrm{L} \mathrm{mol} \mathrm{m}^{-1} \mathrm{~cm}^{-1}\right)$. The value is the slope of the standard curve.

$1=1 \mathrm{~cm}$, the light path of the quartz cell.

Given that, from ferrioxalate actinometry we obtained the following results:

$\mathrm{I}=8.25 \times 10^{-6}$ Einstein $\mathrm{L}^{-1} \mathrm{~s}^{-1}=\underline{8.25 \times 10^{-5} \text { Einstein }^{-1} \text { (photonic flux) }}$

Taking into account that the irradiated area is $0.015 \mathrm{~m}^{2}$ (bottom of the beaker's surface area), the light flux is $5.36 \times 10^{-5}$ Einstein $\mathrm{m}^{-2} \mathrm{~s}^{-1}$. Converting Einstein to Joules $\left(\right.$ Joules/Einstein $=3.4 \times 10^{5}$ ), we have the light flux of 18.2 Joules $\mathrm{m}^{-2} \mathrm{~s}^{-1}$, or $18.2 \mathrm{~W} \mathrm{~m}^{-2}$. As can be observed, this value is very close to that obtained via the spectroradiometer. 


\section{APPENDIX B}

Table B1. Measurements for AMZ calibration curve via HPLC.

\begin{tabular}{c|ccc} 
& \multicolumn{3}{c}{$\begin{array}{c}\text { AMZ retention time }=\mathbf{8 . 5} \text { min } \\
\boldsymbol{\lambda}_{\text {detection }}=\mathbf{2 3 0} \mathbf{~ m m}\end{array}$} \\
\hline $\begin{array}{c}\text { Concentration } \\
\left(\mathbf{m g ~ L}^{-\mathbf{1}}\right)\end{array}$ & Area 1 & Area 2 & Average Area \\
\hline $\mathbf{1 0}$ & 398207 & 401367 & 399787 \\
$\mathbf{9}$ & 360858 & 357206 & 359032 \\
$\mathbf{8}$ & 319705 & 328173 & 323939 \\
$\mathbf{7}$ & 291683 & 283419 & 287551 \\
$\mathbf{6}$ & 240964 & 226699 & 233831,5 \\
$\mathbf{5}$ & 201074 & 194642 & 197858 \\
$\mathbf{4}$ & 161159 & 157856 & 159507,5 \\
$\mathbf{3}$ & 105248 & 121018 & 113133 \\
$\mathbf{2}$ & 76528 & 64286 & 70407 \\
$\mathbf{1}$ & 56117 & 38298 & 47207,5 \\
\hline
\end{tabular}

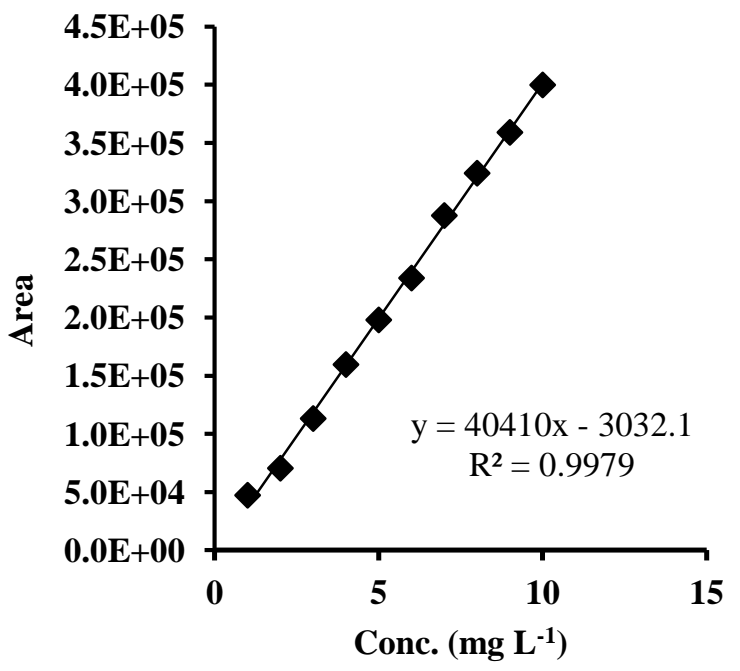

Figure B1. AMZ calibration curve.

For the calculation of LOQ and LOD, lower concentrations must be used. Given that, the following table shows the concentrations used to calculate these parameters:

Table B2 - AMZ concentrations used for LOD and LOQ calculations.

\begin{tabular}{c|ccc}
\hline $\begin{array}{c}\text { Concentration } \\
\left(\mathbf{m g ~ L}^{-1}\right)\end{array}$ & Area 1 & Area 2 & Average Area \\
\hline $\mathbf{1}$ & 56117 & 38298 & 47207.5 \\
$\mathbf{0 . 5}$ & 20049 & 19189 & 19619 \\
$\mathbf{0 . 1}$ & 4952 & 5899 & 5425.5 \\
\hline
\end{tabular}

According to a method described in (SHRIVASTAVA; GUPTA; ARTICLE, 2011), LOD and LOQ can be obtained, as follows: 
$\mathrm{LOD}_{\mathrm{AMZ}}=\frac{\text { Standard error of the predicted } \mathrm{y}-\text { value }}{\text { Slope of calibration curve }} \times 3.3=\frac{3565.89}{4747546783} \times 3.3=$ $0.2515 \mathrm{mg} \mathrm{L}^{-1}=1.03 \mu \mathrm{mol} \mathrm{L}^{-1}$

$\mathrm{LOQ}_{\mathrm{AMZ}}=3 \times \mathrm{LOD}=3.09 \mu \mathrm{mol} \mathrm{L}{ }^{-1}$

The standard value of the predicted y-value was obtained using the "EPADYX" Excel function.

Table B3. Measurements for chlorpyrifos calibration curve via HPLC.

\begin{tabular}{c|ccc}
\hline & \multicolumn{3}{c}{ Chlorpyrifos retention time $=\mathbf{8 . 5}$ min } \\
$\boldsymbol{\lambda}_{\text {detection }}=\mathbf{2 9 0} \mathbf{~ n m}$ & \\
\hline $\begin{array}{c}\text { Concentration } \\
\left(\mathbf{m g ~ L}^{\mathbf{1}}\right)\end{array}$ & Area 1 & Area 2 & Average area \\
\hline $\mathbf{1 0 5}$ & 2650759 & 2650759 & 2650759 \\
$\mathbf{7 5}$ & 1876392 & 1802892 & 1826966 \\
$\mathbf{5 0}$ & 1248779 & 1246173 & 1246563 \\
$\mathbf{3 0}$ & 913879 & 902302 & 905975.7 \\
$\mathbf{2 0}$ & 564686 & 559718 & 562202 \\
$\mathbf{1 5}$ & 479924 & 478983 & 479453.5 \\
$\mathbf{1 0}$ & 319506 & 318925 & 319215.5 \\
$\mathbf{5}$ & 146213 & 143918 & 144933.7 \\
\hline
\end{tabular}

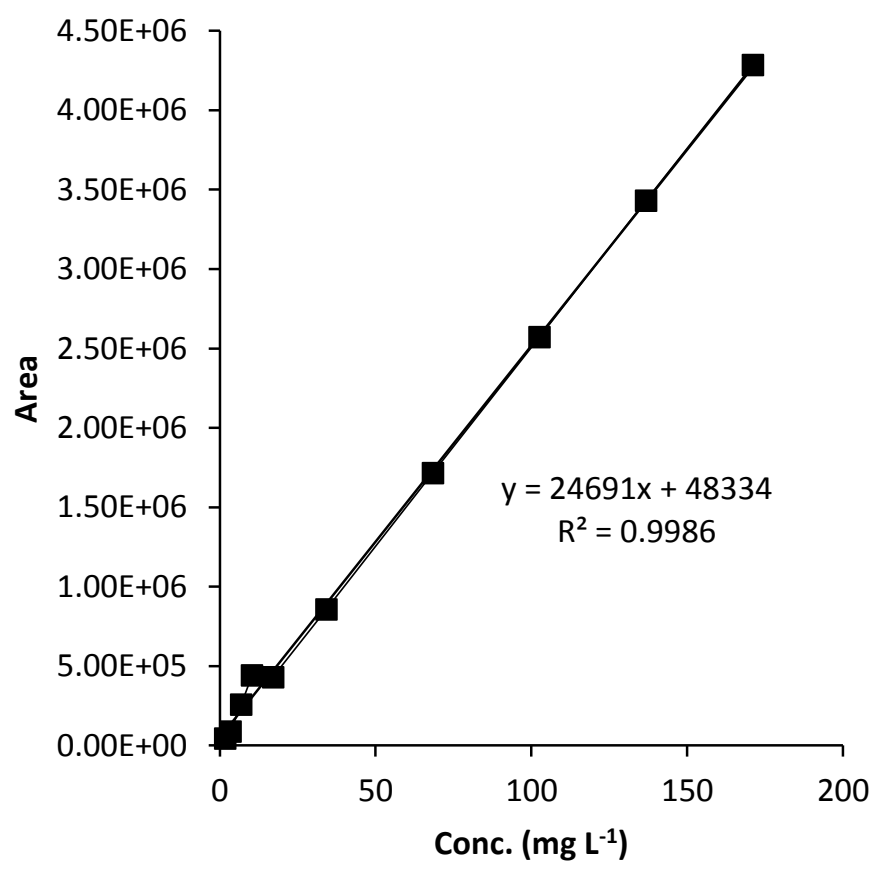

Figure B2. Chlorpyrifos calibration curve $(\lambda=290 \mathrm{~nm})$.

The same procedure was performed for the calculation of chlorpyrifos LOD and LOQ values. 
Table B4- Chlorpyrifos concentrations used for LOD and LOQ calculations.

\begin{tabular}{c|c}
\hline $\begin{array}{c}\text { Concentration } \\
\left(\text { mg L }^{-1}\right)\end{array}$ & Area \\
\hline $\mathbf{1 . 7 1}$ & 44257 \\
$\mathbf{1 . 0 2 6}$ & 26548 \\
$\mathbf{0 . 3 4 2}$ & 17807 \\
$\mathbf{0 . 1 7 1}$ & 8770 \\
$\mathbf{0 . 0 8 5 5}$ & 4410 \\
$\mathbf{0 . 0 3 4 2}$ & 1752 \\
\hline
\end{tabular}

$\mathrm{LOD}_{\text {Chlorpyrifos }}=\frac{\text { Standard error of the predicted } \mathrm{y}-\text { value }}{\text { Slope of calibration curve }} \times 3.3=\frac{3469.143}{23575} \times 3.3=0.486 \mathrm{mg} \mathrm{L}^{-1}=$ $1.39 \mu \mathrm{mol} \mathrm{L}^{-1}$

$\mathrm{LOQ}_{\text {chlorpyrifos }}=3 \times \mathrm{LOD}=4.15 \mu \mathrm{mol} \mathrm{L}{ }^{-1}$ 


\section{APPENDIX C}
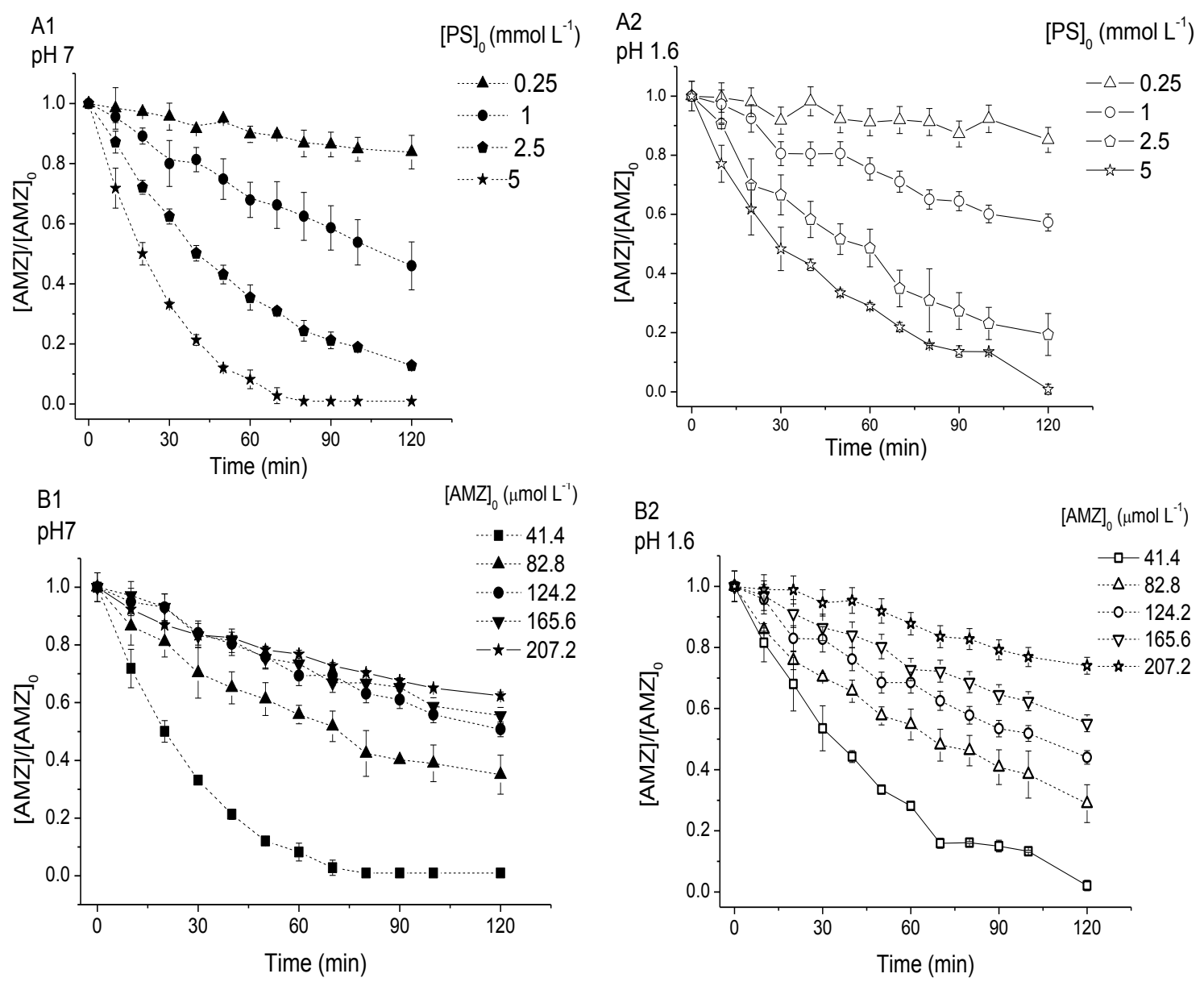

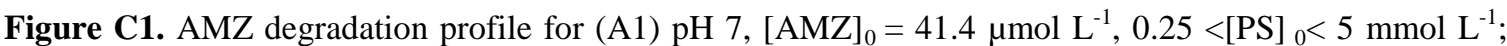

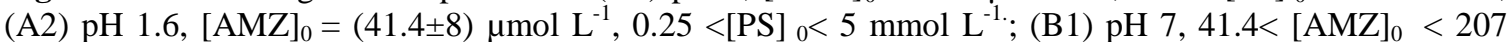

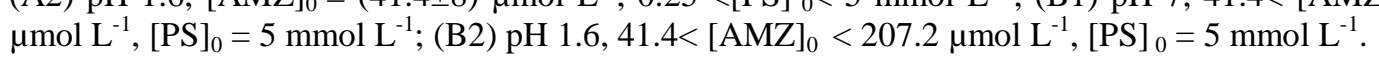




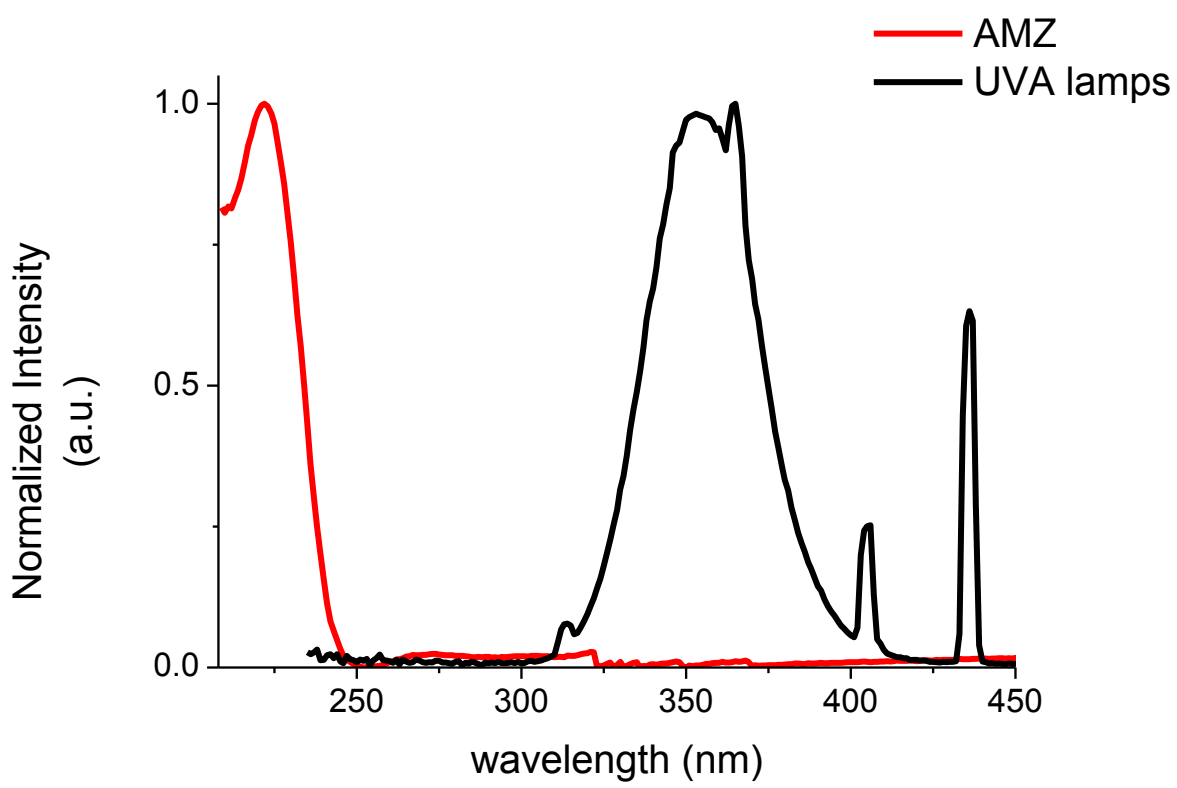

Figure D1. Comparison between AMZ absorption spectrum and the emission spectrum of the UVA lamps.

UVA radiation is expected to promote the LMCT in the Fe(III)-aquacomplex, given the high absorption of the latter within the UVA emission range, as shown in Figure D2.

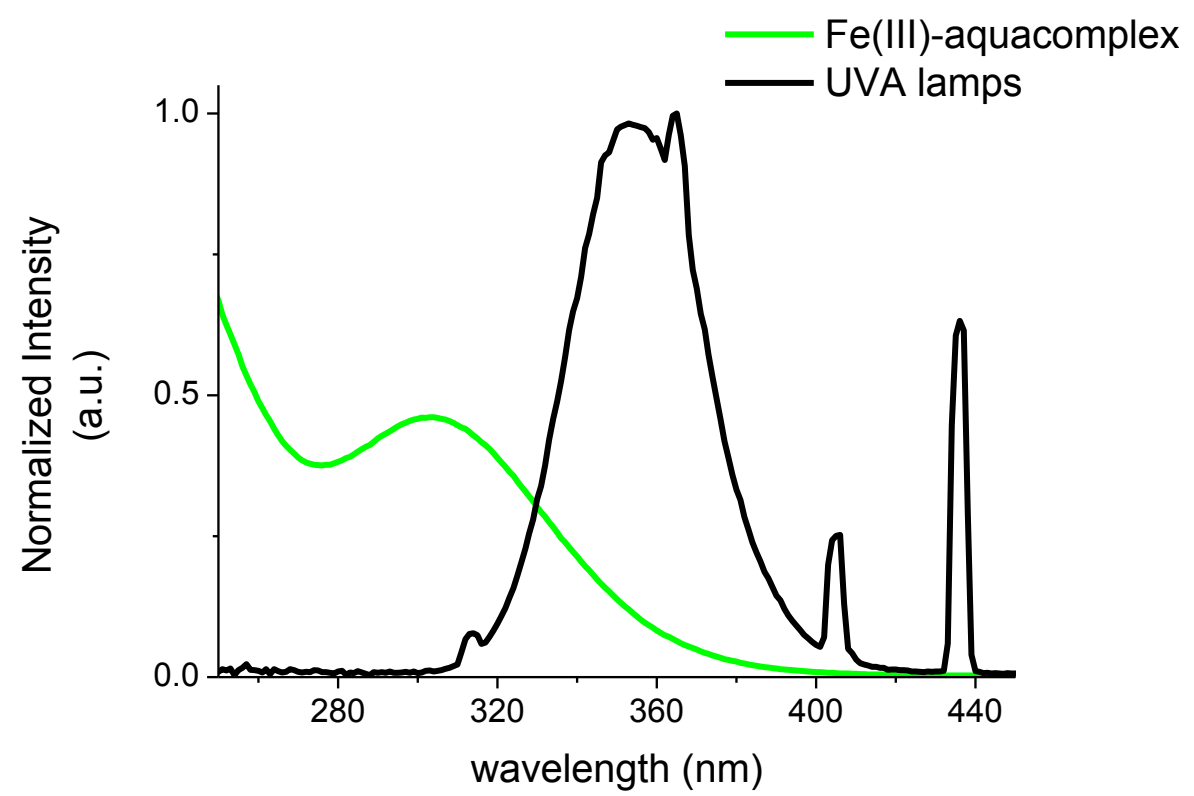

Figure D2. Comparison between Fe(IIII)-aquacomplex absorption spectrum and UVA lamps emission spectrum. 
A

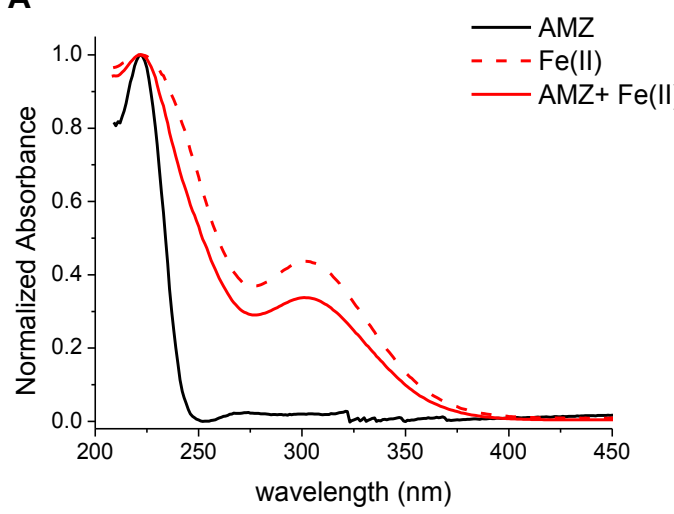

C

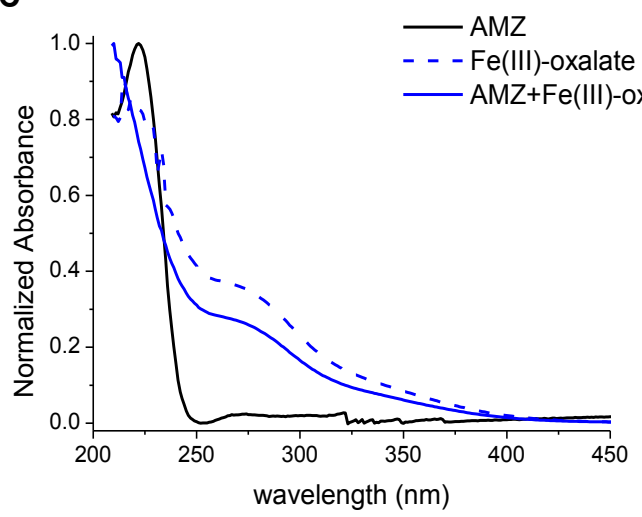

E

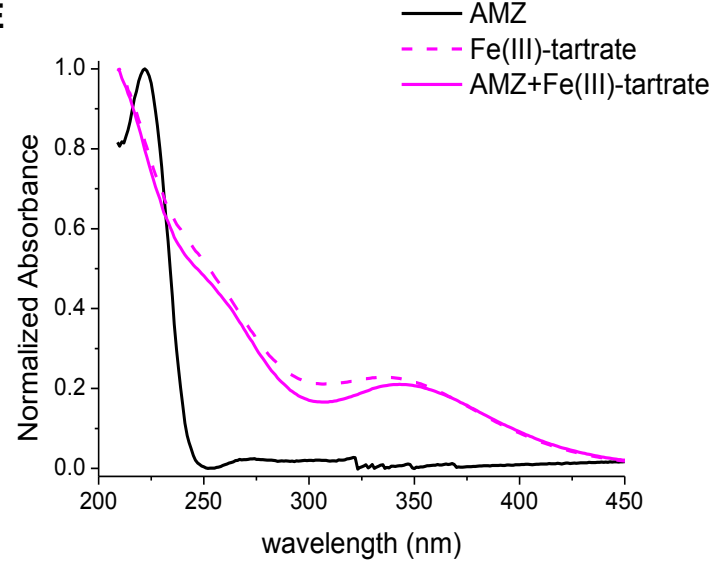

B

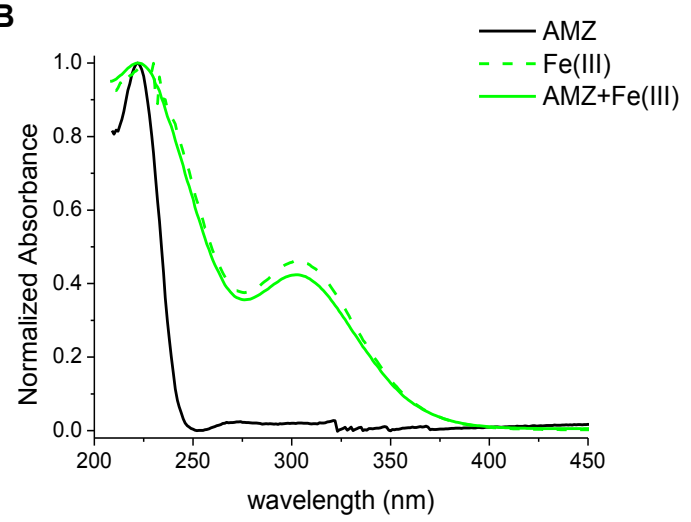

D

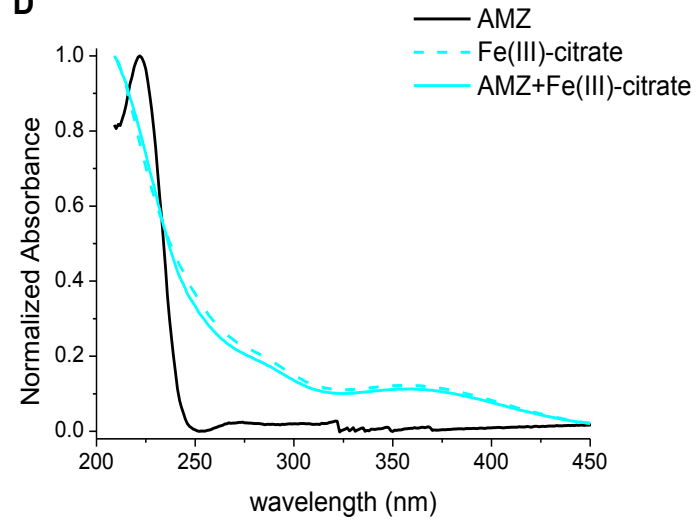

Figure D3. AMZ normalized absorption spectrum in the presence of (A) Fe(II), (B) Fe(III), (C) Fe(III)oxalate complex, (D) $\mathrm{Fe}$ (III)-citrate complex, (E) Fe(III)-tartrate complex. $[\mathrm{Fe}]_{0}=0.1 \mathrm{mmol}$, excess of ligand was used to ensure the complex formation and detection. 


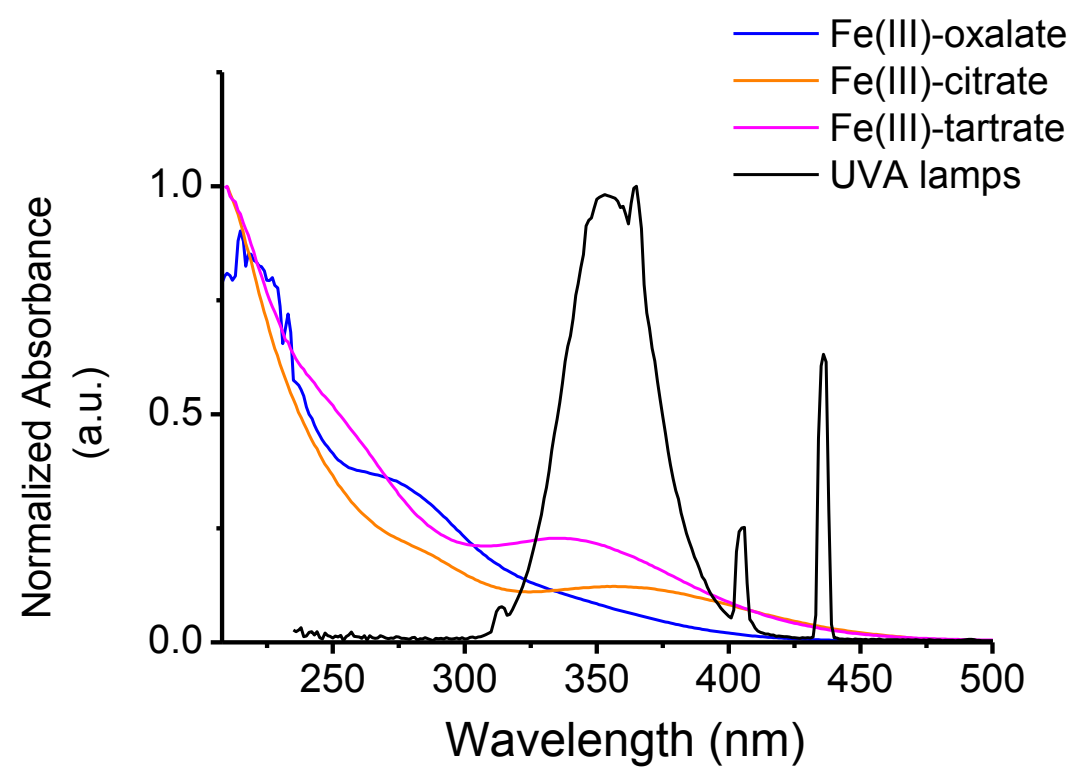

Figure D4. Comparison between Fe(III)-carboxylates absorption spectrum and UVA lamps emission spectrum. $[\mathrm{Fe}]_{0}=0.1 \mathrm{mmol}$. Excess of ligand was used to ensure the complex formation and detection. 


\section{APPENDIX E}

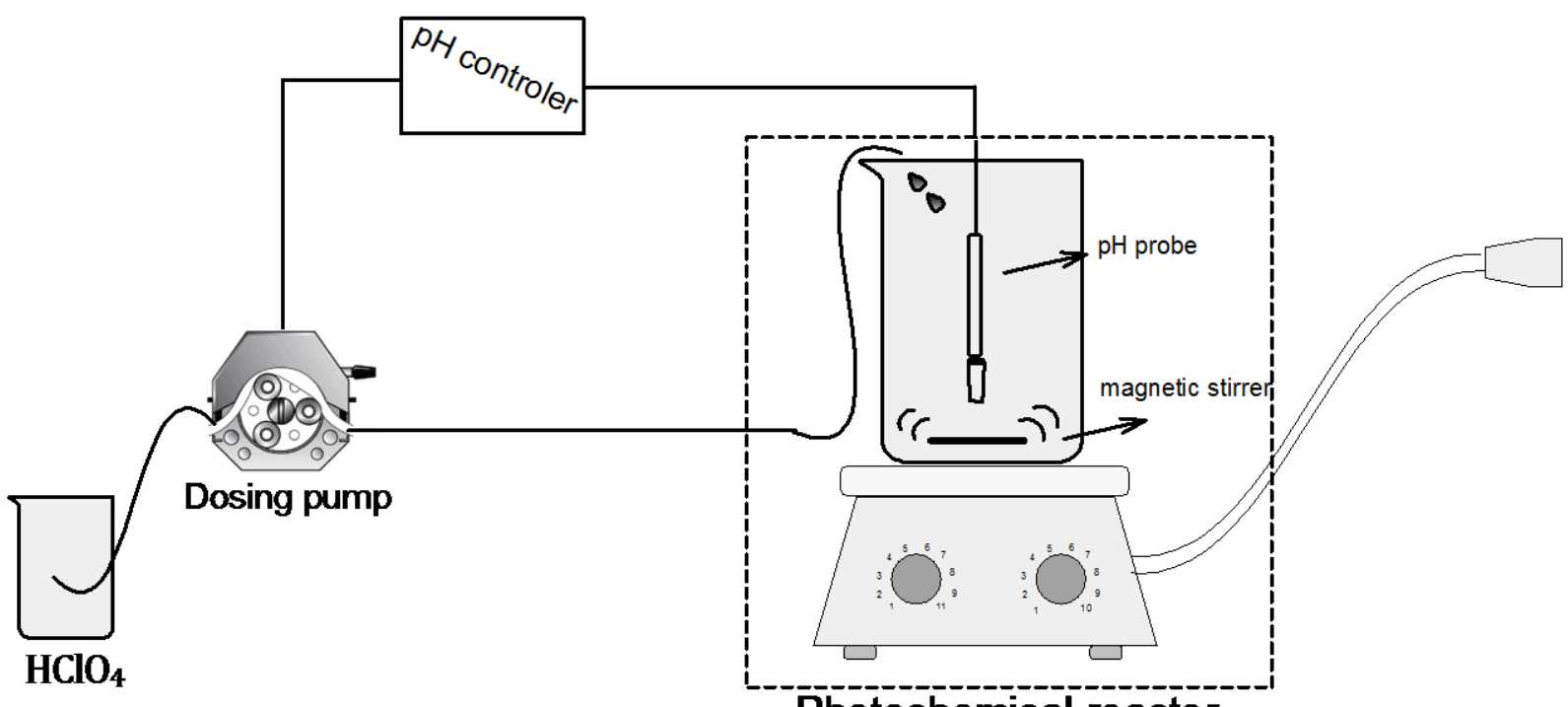

Photochemical reactor

Figure E1. Scheme of the automated pH control system. 


\section{Standardized Pareto Chart for $k_{\mathrm{obs}}$}

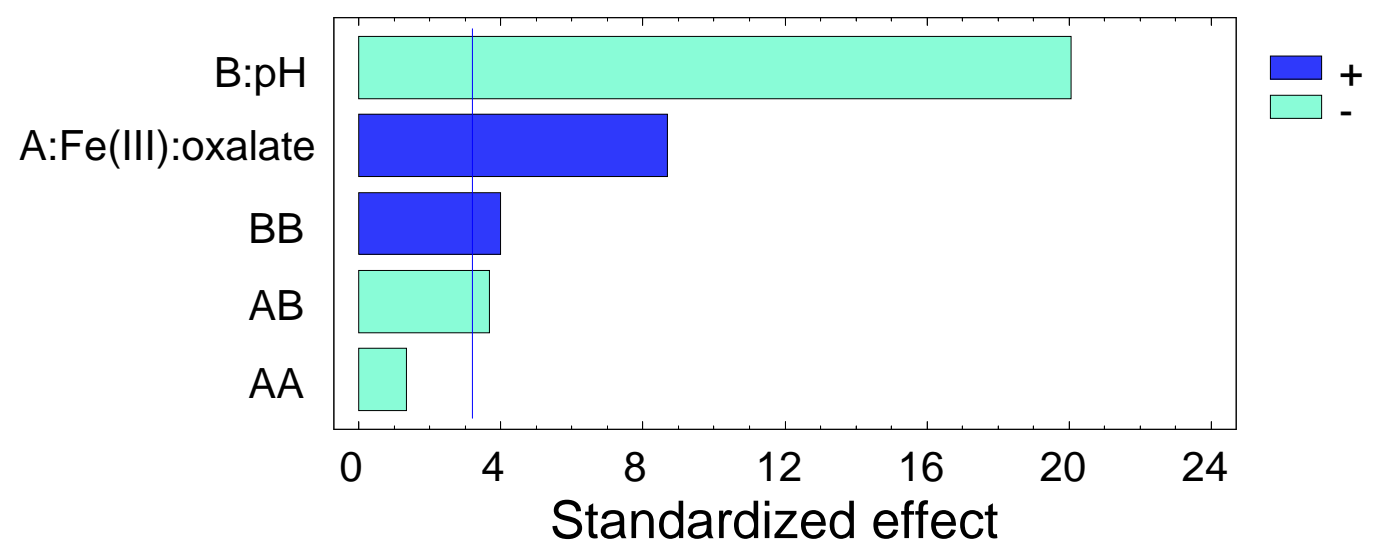

Figure F1. Pareto chart for Fe(III)-oxalate system before displacement.

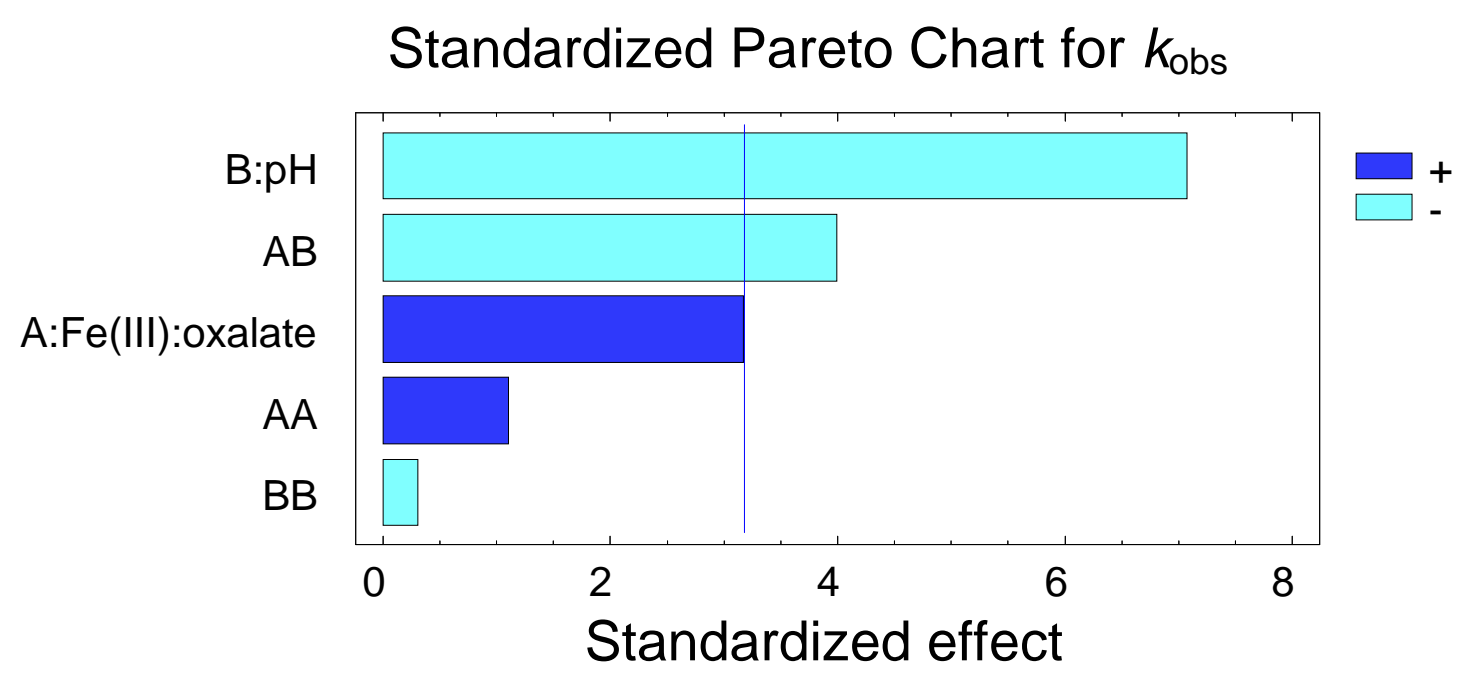

Figure F2. Pareto chart for Fe(III)-oxalate system after displacement.

Table F1. Analysis of variance for $k_{\mathrm{obs}}-\mathrm{Fe}(\mathrm{III})$ :oxalate system before displacement.

\begin{tabular}{lccccc}
\hline \multicolumn{1}{c}{ Source } & $\begin{array}{c}\text { Sum of } \\
\text { squares }\end{array}$ & DF & $\begin{array}{c}\text { Mean } \\
\text { Square }\end{array}$ & F-ratio & $\begin{array}{c}\text { P- } \\
\text { value }\end{array}$ \\
\hline A: Fe(III): oxalate & 192.306 & 1 & 192.306 & 77.25 & 0.0031 \\
B:pH & 1036.84 & 1 & 1036.84 & 416.5 & 0.0003 \\
AA & 4.332 & 1 & 4.332 & 1.74 & 0.2788 \\
AB & 37.7418 & 1 & 37.7418 & 15.16 & 0.03 \\
BB & 45.7749 & 1 & 45.7749 & 18.39 & 0.0233 \\
Total error & 7.46823 & 3 & 2.48941 & & \\
\hline Total (corr.) & 1329.42 & 8 & & & \\
\hline
\end{tabular}


Table F2 - Analysis of variance for $k_{\mathrm{obs}}-\mathrm{Fe}(\mathrm{III})$ :oxalate system after displacement.

\begin{tabular}{lccccc}
\hline \multicolumn{1}{c}{ Source } & $\begin{array}{c}\text { Sum of } \\
\text { squares }\end{array}$ & DfF & $\begin{array}{c}\text { Mean } \\
\text { Square }\end{array}$ & F-ratio & $\begin{array}{c}\text { P- } \\
\text { value }\end{array}$ \\
\hline A: Fe(III): oxalate & 630.791 & 1 & 630.791 & 10.00 & 0.0508 \\
B:pH & 3149.66 & 1 & 3149.66 & 49.94 & 0.00508 \\
AA & 75.272 & 1 & 75.272 & 1.19 & 0.3545 \\
AB & 1000.73 & 1 & 1000.73 & 15.87 & 0.0283 \\
BB & 5.764 & 1 & 5.764 & 0.09 & 0.7822 \\
Total error & 189.199 & 3 & 63.066 & & \\
\hline Total (corr.) & 10502.8 & 8 & & & \\
\hline
\end{tabular}

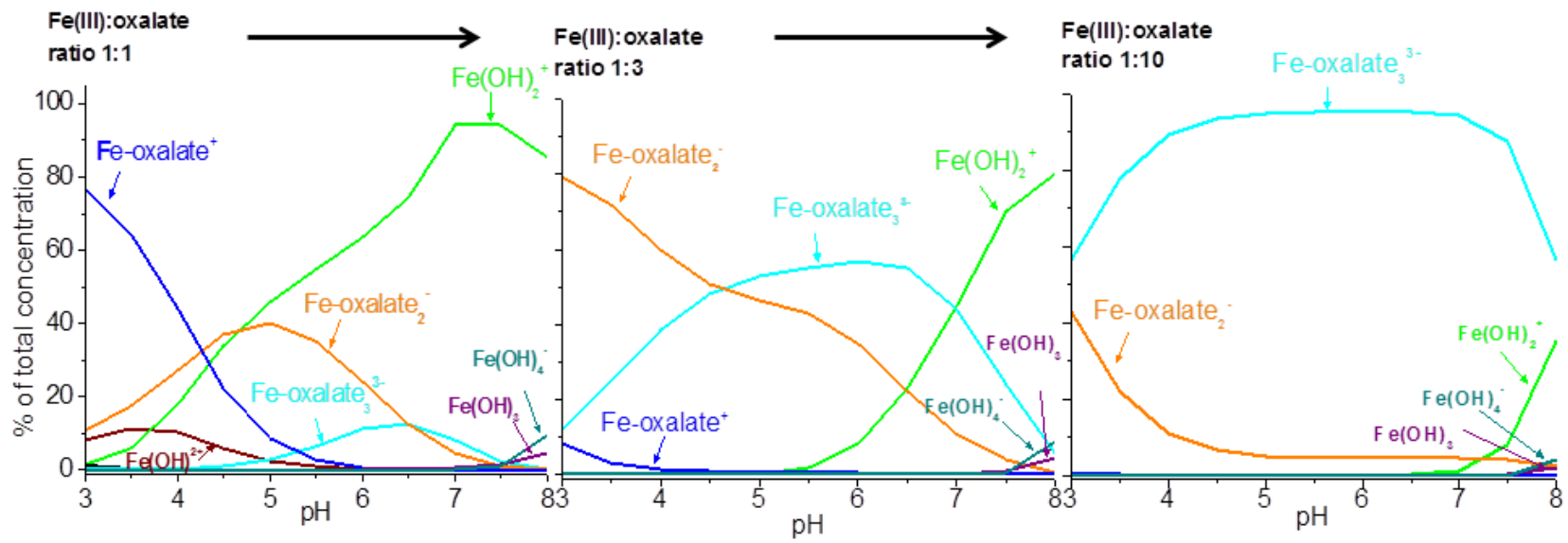

Figure F3. Speciation of Fe(III)-oxalate complexes.

\section{Standardized Pareto Chart for kobs}

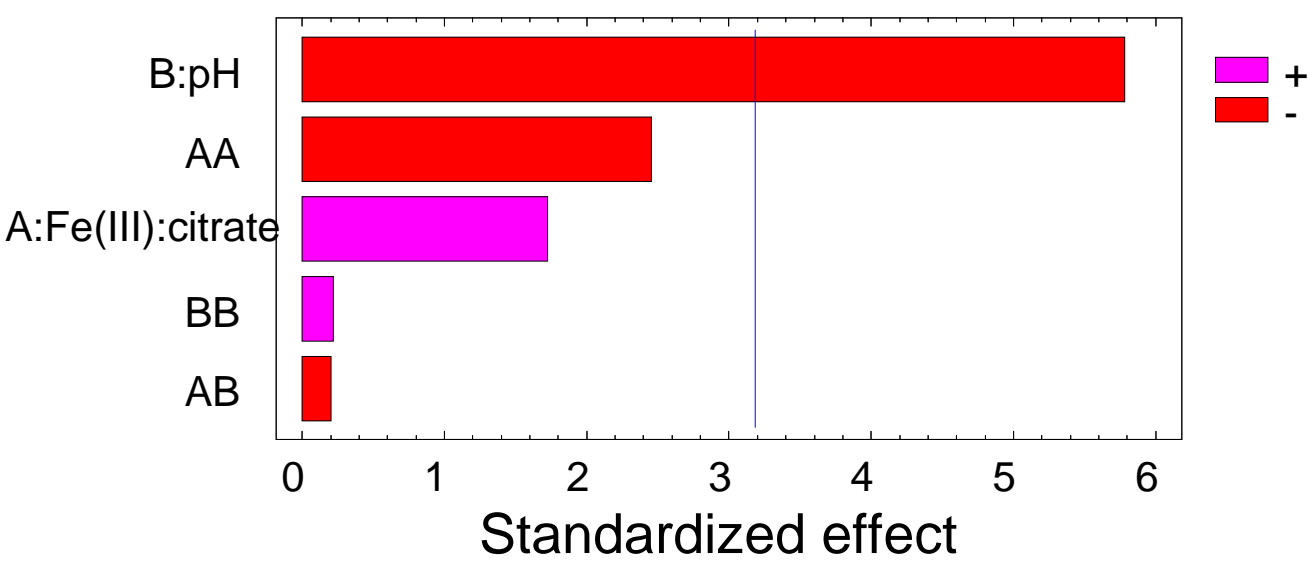

Figure F4. Pareto chart for the $\mathrm{Fe}^{\mathrm{III}}$-citrate system. 
Table F3. Analysis of variance for $k_{\mathrm{obs}}-\mathrm{Fe}(\mathrm{III})$ :citrate system.

\begin{tabular}{lccccc}
\hline \multicolumn{1}{c}{ Source } & $\begin{array}{c}\text { Sum of } \\
\text { squares }\end{array}$ & Df & $\begin{array}{c}\text { Mean } \\
\text { Square }\end{array}$ & $\begin{array}{c}\text { F- } \\
\text { ratio }\end{array}$ & $\begin{array}{c}\text { P- } \\
\text { value }\end{array}$ \\
\hline A: Fe(III): citrate & 6.706 & 1 & 6.706 & 2.96 & 0.1841 \\
B:pH & 75.69 & 1 & 75.69 & 33.36 & 0.0103 \\
AA & 13.60 & 1 & 13.60 & 5.99 & 0.0918 \\
AB & 0.0899 & 1 & 0.0899 & 0.04 & 0.8549 \\
BB & 0.105 & 1 & 0.105 & 0.05 & 0.8436 \\
Total error & 6.80 & 3 & 2.269 & & \\
\hline Total (corr.) & 103.82 & 8 & & & \\
\hline
\end{tabular}

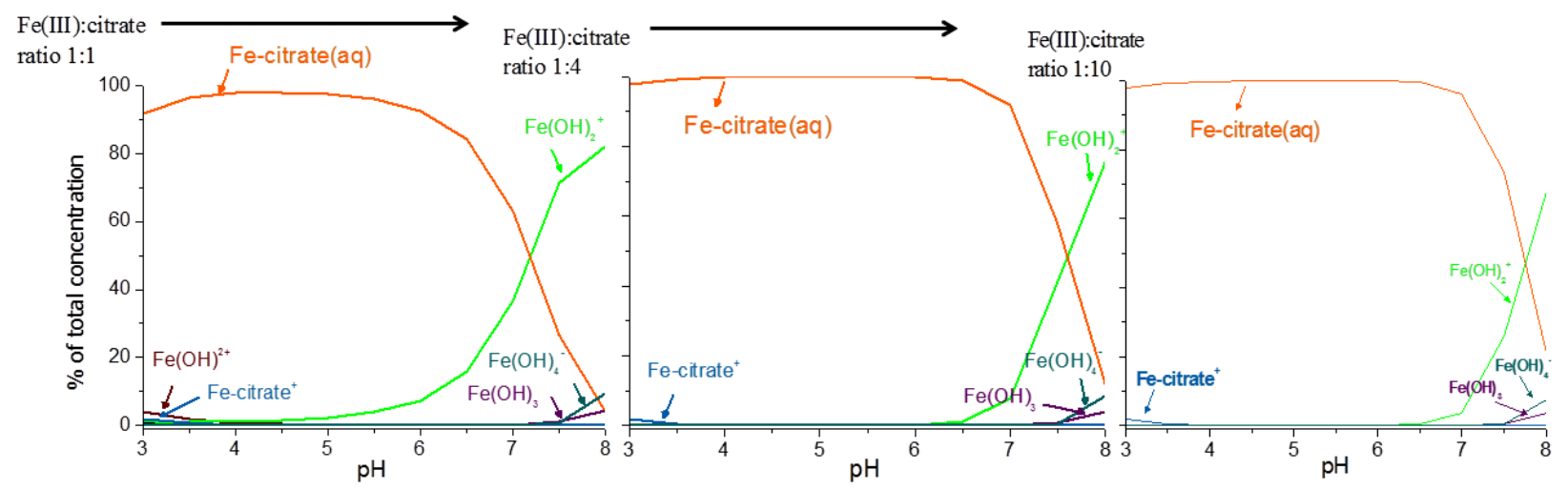

Figure F5. Speciation of Fe(III)-citrate complexes.

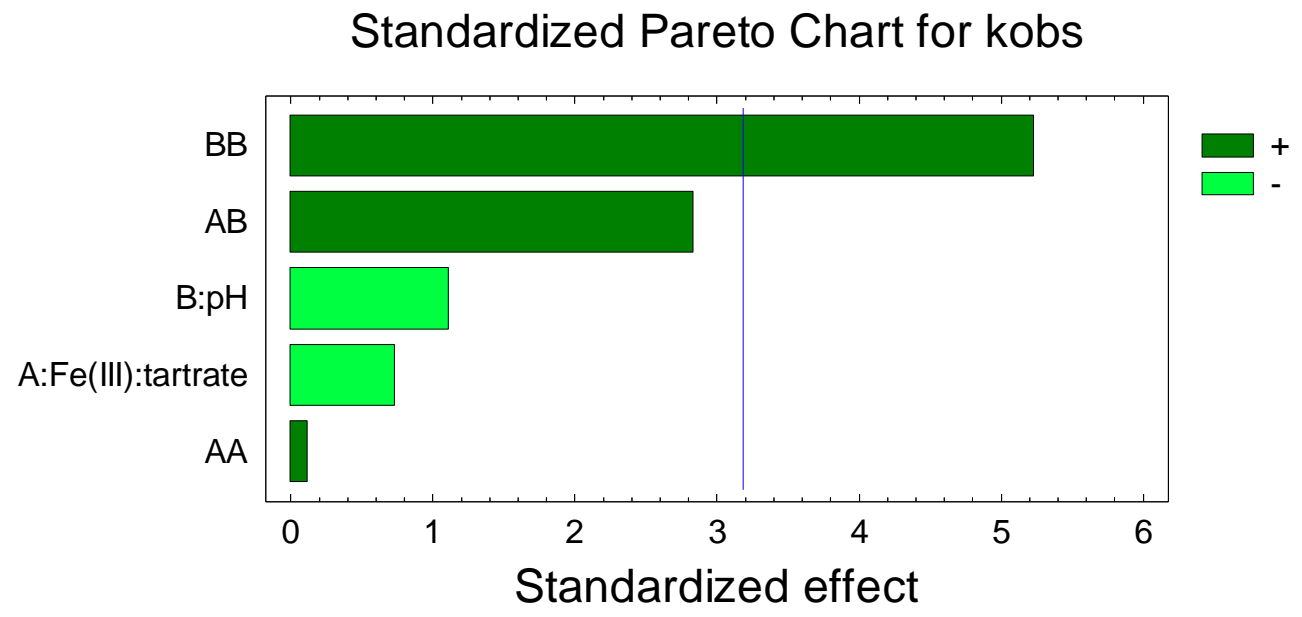

Figure F6. Pareto chart for the Fe(III)-tartrate system. 
Table F4 . Analysis of variance for $k_{\mathrm{obs}}-\mathrm{Fe}(\mathrm{III})$ :tartrate system.

\begin{tabular}{lccccc}
\hline \multicolumn{1}{c}{ Source } & $\begin{array}{c}\text { Sum of } \\
\text { squares }\end{array}$ & DF & $\begin{array}{c}\text { Mean } \\
\text { Square }\end{array}$ & $\begin{array}{c}\boldsymbol{F} \text { - } \\
\text { ratio }\end{array}$ & $\begin{array}{c}\text { P- } \\
\text { value }\end{array}$ \\
\hline A: Fe(III): tartrate & 0.049 & 1 & 0.049 & 0.53 & 0.518 \\
B:pH & 0.113 & 1 & 0.113 & 1.24 & 0.348 \\
AA & 0.001 & 1 & 0.001 & 0.01 & 0.912 \\
AB & 0.736 & 1 & 0.736 & 8.04 & 0.066 \\
BB & 2.506 & 1 & 2.506 & 27.37 & 0.014 \\
Total error & 0.275 & 3 & 0.092 & & \\
\hline Total (corr.) & 13.88 & 8 & & & \\
\hline
\end{tabular}

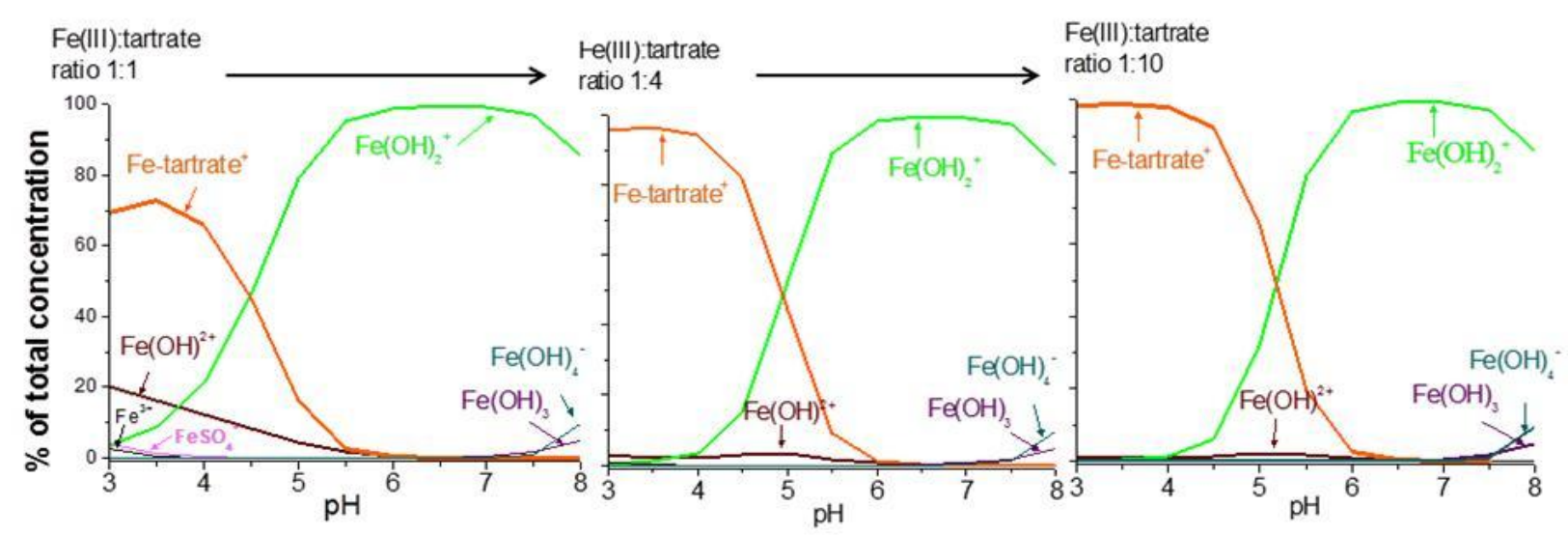

Figure F7. Speciation of Fe(III)-tartrate complexes.

Table F5. Relative reactivity - Fe(III)-carboxylate/Fe(III)-aquacomplex.

\begin{tabular}{|c|c|c|c|c|}
\hline \multirow{2}{*}{$\mathbf{p H}$} & \multirow{2}{*}{$\begin{array}{c}\text { Fe(III):ligand } \\
\text { ratio }\end{array}$} & \multicolumn{3}{|c|}{$\boldsymbol{k}_{\text {obs Fe(III)-carboxylate }} \boldsymbol{k}_{\text {obs Fe(III)-aquacomplex }}$} \\
\cline { 3 - 5 } & & $\mathrm{Fe}(\mathrm{III})-$ Oxalate & $\mathrm{Fe}(\mathrm{III})$-Citrate & Fe(III)-Tartrate \\
\hline \multirow{3}{*}{3.5} & $1: 2$ & 2.2 & 0.8 & 0.3 \\
\cline { 2 - 5 } & $1: 4$ & 3.1 & 1.0 & 0.2 \\
\cline { 2 - 5 } & $1: 10$ & 8.0 & 0.4 & 0.3 \\
\hline
\end{tabular}




\section{APPENDIX G}

Table G1: WC Medium Composition (ANDERSEN R., 2005).

\begin{tabular}{|c|c|c|c|}
\hline \multicolumn{4}{|c|}{ WC Medium Composition * } \\
\hline Component & $\begin{array}{l}\text { Stock Solution } \\
\quad\left(\mathrm{g} \mathrm{L}^{-1}\right)\end{array}$ & Volume & $\begin{array}{l}\text { Concentration in } \\
\text { the final medium } \\
\left(\mathrm{mol} \mathrm{L}^{-1}\right)\end{array}$ \\
\hline $\mathrm{NaNO}_{3}$ & 85.01 & $1 \mathrm{~mL}$ & $1.00 \times 10^{-3}$ \\
\hline $\mathrm{CaCl}_{2} .2 \mathrm{H}_{2} \mathrm{O}$ & 36.76 & $1 \mathrm{~mL}$ & $2.50 \times 10^{-4}$ \\
\hline $\mathrm{MgSO}_{4} \cdot 7 \mathrm{H}_{2} \mathrm{O}$ & 36.97 & $1 \mathrm{~mL}$ & $1.50 \times 10^{-4}$ \\
\hline $\mathrm{NaHCO}_{3}$ & 12.60 & $1 \mathrm{~mL}$ & $1.50 \times 10^{-4}$ \\
\hline $\mathrm{Na}_{2} \mathrm{SiO}_{3} .9 \mathrm{H}_{2} \mathrm{O}$ & 28.42 & $1 \mathrm{~mL}$ & $1.00 \times 10^{-4}$ \\
\hline $\mathrm{K}_{2} \mathrm{HPO}_{2}$ & 8.71 & $1 \mathrm{~mL}$ & $5.00 \times 10^{-5}$ \\
\hline $\begin{array}{c}\text { Trace metals } \\
\text { solution }\end{array}$ & (see below) & $1 \mathrm{~mL}$ & $5.00 \times 10^{-5}$ \\
\hline Vitamins solution & (see below) & $1 \mathrm{~mL}$ & $5.00 \times 10^{-5}$ \\
\hline \multicolumn{4}{|c|}{ Trace Metals Solution } \\
\hline Component & $\begin{array}{c}1^{\text {a }} \text { Stock } \\
\left(\mathrm{g} \mathrm{L}^{-1}\right)\end{array}$ & $\begin{array}{l}\text { Quantity } \\
\text { Used }\end{array}$ & $\begin{array}{l}\text { Concentration in } \\
\text { the final medium } \\
\left(\mathrm{mol} \mathrm{L}^{-1}\right)\end{array}$ \\
\hline NaEDTA . $2 \mathrm{H}_{2} \mathrm{O}$ & - & $4.36 \mathrm{~g}$ & $1.17 \times 10^{-5}$ \\
\hline $\mathrm{FeCl}_{3} \cdot 6 \mathrm{H}_{2} \mathrm{O}$ & - & $3.15 \mathrm{~g}$ & $1.17 \times 10^{-5}$ \\
\hline $\mathrm{CuSO}_{4} \cdot 5 \mathrm{H}_{2} \mathrm{O}$ & 10.0 & $1 \mathrm{~mL}$ & $4.01 \times 10^{-8}$ \\
\hline $\mathrm{ZnSO}_{4} \cdot 7 \mathrm{H}_{2} \mathrm{O}$ & 22.0 & $1 \mathrm{~mL}$ & $7.65 \times 10^{-8}$ \\
\hline $\mathrm{CoCl}_{2} \cdot 6 \mathrm{H}_{2} \mathrm{O}$ & 10.0 & $1 \mathrm{~mL}$ & $4.20 \times 10^{-8}$ \\
\hline 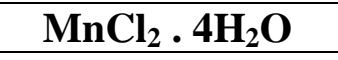 & 180.0 & $1 \mathrm{~mL}$ & $9.10 \times 10^{-7}$ \\
\hline $\mathrm{Na}_{2} \mathrm{MoO}_{4} \cdot 2 \mathrm{H}_{2} \mathrm{O}$ & 6.0 & $1 \mathrm{~mL}$ & $2.48 \times 10^{-8}$ \\
\hline $\mathrm{MgSO}_{4}$ & - & $1.0 \mathrm{~g}$ & $1.62 \times 10^{-5}$ \\
\hline
\end{tabular}

\begin{tabular}{c|c|c|c}
\hline \multicolumn{4}{|c}{ Vitamins Solution ** } \\
\hline Component & $\begin{array}{c}\mathbf{1}^{\text {a Stock }} \\
\left(\mathbf{g ~ L}^{-\mathbf{1}}\right)\end{array}$ & $\begin{array}{c}\text { Quantity } \\
\text { Used }\end{array}$ & $\begin{array}{c}\text { Concentration in } \\
\text { the final medium } \\
\left(\mathbf{m o l ~ L}^{-\mathbf{1}}\right)\end{array}$ \\
\hline Thiamine-HCl & - & $100 \mathrm{mg}$ & $2.96 \times 10^{-7}$ \\
\hline Biotin & 0.5 & $1 \mathrm{~mL}$ & $2.05 \times 10^{-9}$ \\
\hline Cyanocobalamin & 0.5 & $1 \mathrm{~mL}$ & $3.69 \times 10^{-10}$ \\
\hline
\end{tabular}

* The volumes of stock solutions, except the vitamin solution, were added into a volumetric flask and the final volume $(1 \mathrm{~L})$ was completed with deionized water. The solution was autoclavesterilized and stored in refrigerator.

** The vitamins solution was filter-sterilized and stored in refrigerator. The vitamins solution was then added to the sterilized medium. 


\section{APPENDIX H}
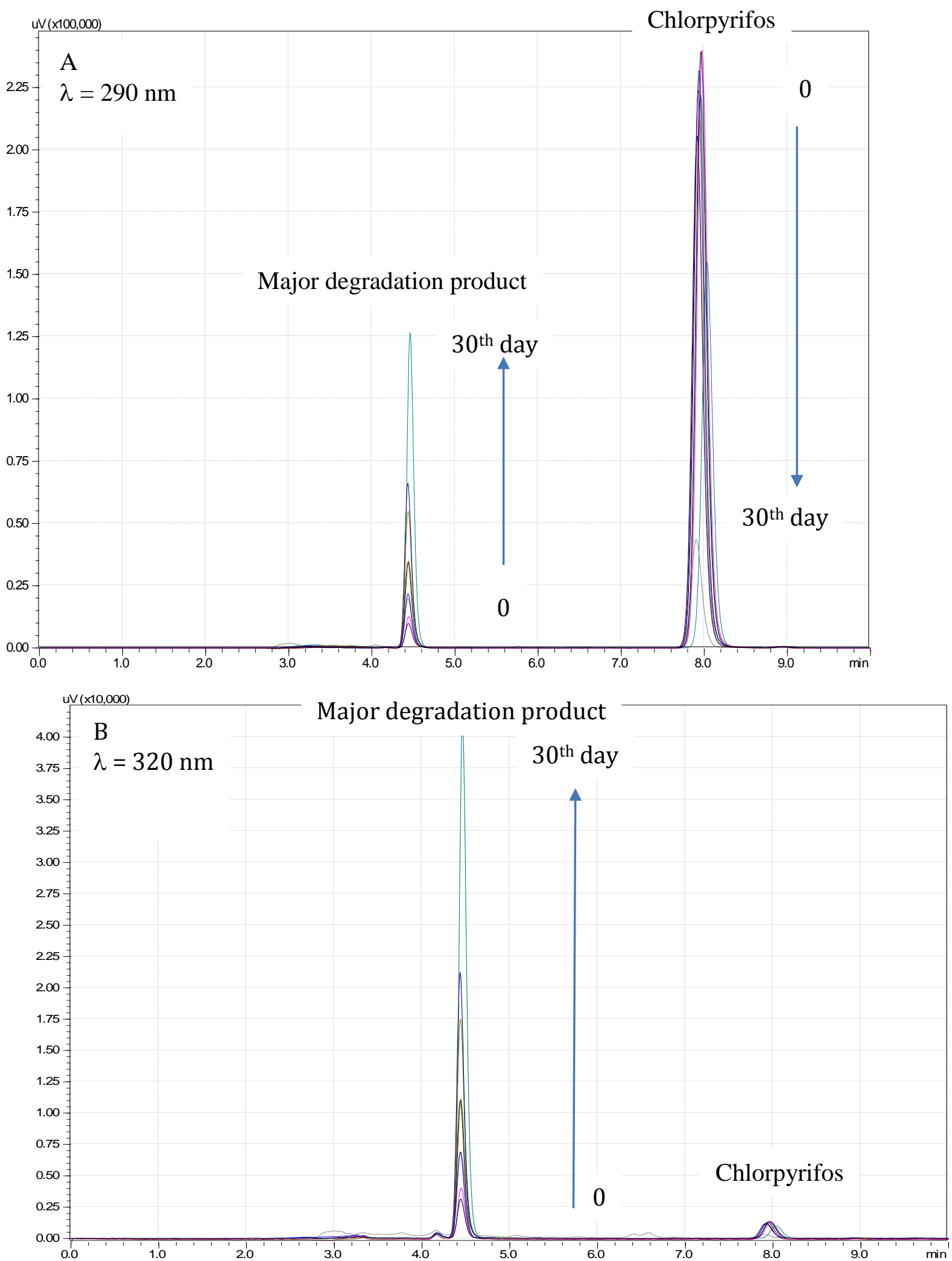

Figure H1. Chlorpyrifos chromatograms for (A) 290 and (B) $320 \mathrm{~nm}$, overlapped from 0 to 30 day degradation, promoted by $0.5 \%(w / V)$ of $\mathrm{Zn}$. 